Portland State University

PDXScholar

7-14-2017

\title{
The Littlefield Rhyolite, Eastern Oregon: Distinct Flow Units and Their Constraints on Age and Storage Sites of Grande Ronde Basalt Magmas
}

Brian McCulloch Webb

Portland State University

Follow this and additional works at: https://pdxscholar.library.pdx.edu/open_access_etds

Part of the Geology Commons

Let us know how access to this document benefits you.

\section{Recommended Citation}

Webb, Brian McCulloch, "The Littlefield Rhyolite, Eastern Oregon: Distinct Flow Units and Their Constraints on Age and Storage Sites of Grande Ronde Basalt Magmas" (2017). Dissertations and Theses. Paper 4022.

https://doi.org/10.15760/etd.5906

This Thesis is brought to you for free and open access. It has been accepted for inclusion in Dissertations and Theses by an authorized administrator of PDXScholar. Please contact us if we can make this document more accessible: pdxscholar@pdx.edu. 
The Littlefield Rhyolite, Eastern Oregon:

Distinct Flow Units and Their Constraints on Age and Storage Sites of

Grande Ronde Basalt Magmas

by

Brian McCulloch Webb

A thesis submitted in partial fulfillment of the requirements for the degree of

\author{
Master of Science \\ in \\ Geology
}

Thesis Committee: Martin J. Streck, Chair John Bershaw Michael L. Cummings

Portland State University 2017 


\begin{abstract}
The Littlefield Rhyolite consists of widespread, high-temperature, hotspot-related rhyolitic lavas that erupted in eastern Oregon contemporaneous to late-stage Grande Ronde Basalt lavas. The estimated total volume of erupted rhyolites is $\sim 100$ $\mathrm{km}^{3}$ covering $\sim 850 \mathrm{~km}^{2}$.
\end{abstract}

The focus of this study has been to investigate the stratigraphy and petrology of the Littlefield Rhyolite and whether field and geochemical relationships exist to help constrain the timing and storage sites of Grande Ronde Basalt magmas. Although often indistinguishable in the field, our data reveal that the Littlefield Rhyolite consists of two geochemically distinct rhyolite flow packages that are designated here as lower and upper Littlefield Rhyolite, according to stratigraphic relationships in the Malheur River Gorge. Rarely viewed in sequence, these rhyolites are distinguished by $\mathrm{Zr}, \mathrm{Ba}, \mathrm{Nb}, \mathrm{TiO}_{2}$ and $\mathrm{FeO}$ contents and ${ }^{40} \mathrm{Ar} /{ }^{39} \mathrm{Ar}$ ages $(16.12 \pm 0.04$ and 16.16 \pm 0.10 Ma versus $16.01 \pm 0.06$ and $16.05 \pm 0.04 \mathrm{Ma})$.

Rhyolites known either as 'rhyolite of Cottonwood Mountain' or 'rhyolite of Bully Creek Canyon', and which are exposed around Cottonwood Mountain, northwest of Vale, have compositions similar to samples of lower Littlefield Rhyolite. Additionally, single crystal ${ }^{40} \mathrm{Ar} /{ }^{39} \mathrm{Ar}$ ages of two samples $(16.12 \pm 0.07,16.20 \pm 0.08)$ are statistically indistinguishable.

Among units sandwiched between the lower and upper Littlefield Rhyolite are several lava flows and a one-meter thick agglutinated spatter deposit of Hunter 
Creek Basalt. The spatter deposit thickens to 10s of meters over a distance of $800 \mathrm{~m}$ where the deposit is strongly welded. We recognize this as a venting site of Hunter Creek Basalt, and that Hunter Creek Basalt is geochemically and petrographically similar to, and contemporaneous with, late-stage Grande Ronde Basalt. Ages of Littlefield Rhyolite flow units constrain the timing of eruption of Hunter Creek Basalt to an age span of $\sim 100 \mathrm{k}$ years, between $16.05-16.12$ Ma.

One local variant of late-stage Grand Ronde Basalt is icelanditic ( $\sim 62$ wt. \% $\mathrm{SiO}_{2}$ ) and is found at a number of places including a location near the southern extent of the upper Littlefield Rhyolite. Geochemical modeling strongly suggests that icelandite lavas resulted from mixing of Grande Ronde and upper Littlefield Rhyolite magmas, thereby tying a Grande Ronde magma storage site to within the greater Malheur River Gorge area, and indicating contemporaneity of rhyolitic and Grande Ronde magma reservoirs. 


\section{ACKNOWLEDGMENTS}

Martin Streck has been an outstanding advisor. I am grateful for his continuous support and guidance throughout my undergraduate and graduate studies in Geology. He suggested a truly intriguing project to pursue, and my work on the Littlefield Rhyolite would not have been possible without him. I thank Mark Ferns for sharing his unparalleled experience with the geology of eastern Oregon throughout this project. I also thank William McIntosh for his ongoing support throughout this study. William McIntosh worked with us and ultimately acquired the first successful ages for these historically troublesome rhyolites. Without his extensive expertise and personalized support on this project, I do not believe we would have acquired useful ${ }^{40} \mathrm{Ar} /{ }^{39} \mathrm{Ar}$ results. I am grateful for the efforts of my thesis committee-Martin Streck, Michael Cummings, and John Bershaw--who reviewed and revised my work. I especially want to recognize Michael Cummings for his pioneering work in southeast Oregon. His thoughtful comments and suggestions helped to shape the final draft of my work. I also thank Vic Camp, John Wolff, Jason McClaughry, and Clark Niewendorp for helpful discussions related to this project. Finally, I wish to thank my family for their support, especially my parents and Tetyana. 


\section{TABLE OF CONTENTS}

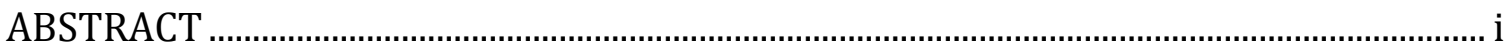

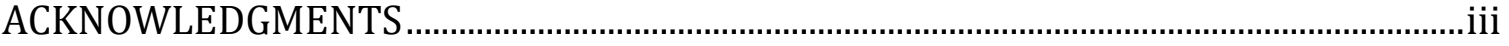

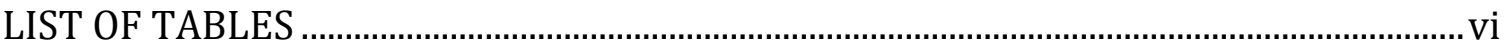

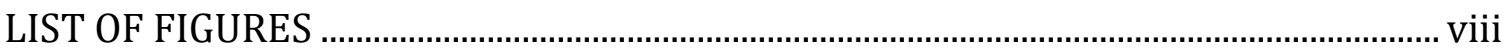

CHAPTER 1: INTRODUCTION ……..................................................................................... 1

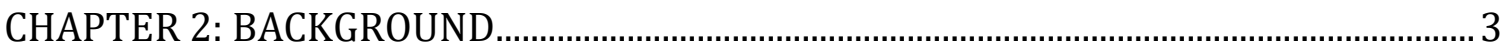

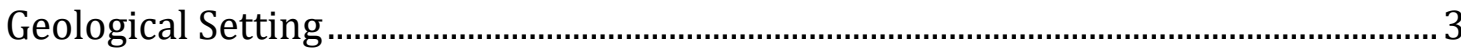

Main Phase Columbia River Basalt Group (CRBG) …………………………………..... 3

The Malheur River Gorge: Crossroads of Main Phase CRBG Emplacement ................. 7

Basalt of Malheur Gorge ............................................................................................ 8

Onset of Bimodal Volcanism--The Hog Creek Formation............................................. 10

The Littlefield Rhyolite ............................................................................................... 11

Prior Work On The Littlefield Rhyolite............................................................................. 14

Identification of the Lower Littlefield Rhyolite ......................................................... 17

Prior Age Dates for the Littlefield Rhyolite ............................................................... 21

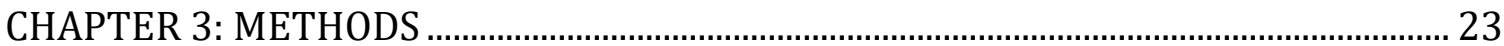

CHAPTER 4: RESULTS................................................................................................ 26

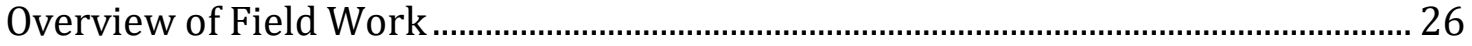

Stratigraphy of Transects........................................................................................ 28

Primary Transect at Namorf within the Malheur River Gorge ................................ 28

Northern Stratigraphic Transects.............................................................................. 40

Southern Stratigraphic Transect in Alder Creek Canyon ............................................ 42

Lithology, Petrography, and Geochemistry of Stratigraphic Units ............................ 46

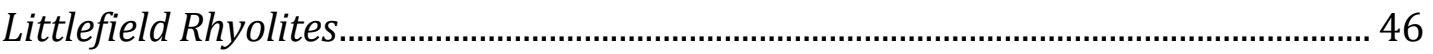

${ }^{40} \mathrm{Ar} /{ }^{39} \mathrm{Ar}$ Age Dating of Littlefield Rhyolites ............................................................. 62

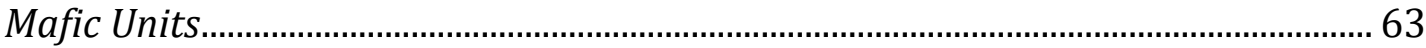

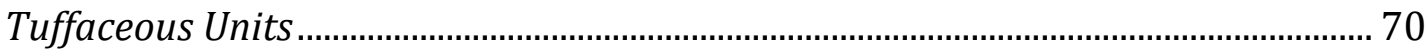

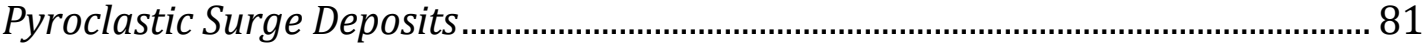


Flood Rhyolites: Effective Viscosity and Lava Flow Morphology of Large Hotspotrelated Rhyolites......................................................................................................... 82

Rhyolite Lava Flow Morphology ................................................................................. 82

High Temperature, Hot-spot Related, Rhyolite Lava Flow Morphology ................... 83

Littlefield Rhyolites Flow Morphology ....................................................................... 84

Geochemical Correlations of Basalt of Malheur Gorge, Hunter Creek Basalt, and Main Phases of the Columbia River Basalt Group............................................................. 85

Icelandite of Alder Creek Canyon: A Mixture of Grande Ronde Basalt and Upper

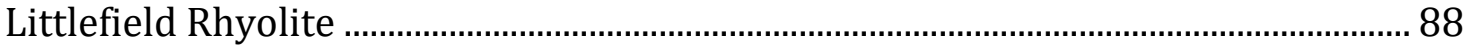

Potential Sources of Crustal Contamination .................................................................... 92

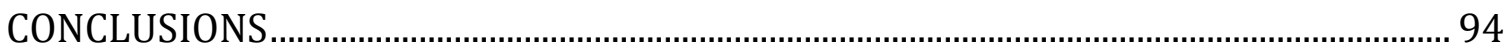

REFERENCES ............................................................................................................. 95

APPENDIX A: XRF \& ICP-MS CHEMICAL DATA …………………………………….......103

X-Ray Fluorescence (XRF) and ICP-MS Sample Location Map ..................................103

X-Ray Fluorescence (XRF) Chemical Data .....................................................................104

Inductively Coupled Plasma-Mass Spectrometry (ICP-MS) Chemical Data............111

APPENDIX B: PORTABLE X-RAY FLUORESCENCE (PXRF) CHEMICAL DATA ...........118

Portable X-Ray Fluorescence (pXRF) Sample Location Map........................................118

Portable X-Ray Fluorescence (pXRF) Data for Rhyolite Lava Samples ....................119

APPENDIX C: ELECTRON PROBE MICRO-ANALYZER (EPMA) DATA ............................120

Upper Littlefield Rhyolite: Sample BW-14-67 ...........................................................120

Lower Littlefield Rhyolite: Sample BW-14-19 ...........................................................123

Dinner Creek Tuff: Sample BW-14-45 .......................................................................126

Epiclastic Tuff: Sample BW-14-12 ……………………...........................................127

APPENDIX D: SCANNING ELECTRON MICROSCOPE (SEM) CHEMICAL DATA..........128

Lower Littlefield Rhyolite: Sample BW-13-02 …………………………………......128

Lower Littlefield Rhyolite: Sample BW-13-03 ……………………………………...131

APPENDIX E: ${ }^{40} \mathrm{Ar} /{ }^{39} \mathrm{Ar}$ DATING OF RHYOLITE LAVAS................................................133

APPENDIX F: GEOLOGICAL MAP OF THE PRIMARY TRANSECT SITE AT NAMORF143 


\section{LIST OF TABLES}

Table 1: Prior age dates for Littlefield Rhyolite, rhyolite of Cottonwood Mountain, and rhyolite of Bully Creek Canyon. Littlefield Rhyolite samples of Hooper et al. (2003), Lees (1994), and Hess (2014, are for what we refer to here as the upper Littlefield Rhyolite. Littlefield Rhyolite sample of Kittleman et al. (unpublished) is likely the same, but with uncertainty given the sample location provided. *Unpublished sample of Kittleman recalculated by Fiebelkorn et al. (1983) ...........22

Table 2: XRF data comparing the average major element compositions of six samples of upper Littlefield Rhyolite (upper LFR) and 13 samples of lower Littlefield Rhyolite (lower LFR). In contrast to the underlying tholeiitic lavas, the major and trace element compositions of both Littlefield rhyolites are notably homogenous throughout their extensive thicknesses and relatively widespread emplacements

Table 3: The average, minimum, and maximum calculated end-member compositions from electron Microprobe (EMP) analyses of upper Littlefield Rhyolite feldspar phenocrysts. Upper Littlefield Rhyolite sample number: BW-14-67. 53

Table 4: The average, minimum, and maximum calculated end-member compositions from electron Microprobe (EMP) analyses of upper Littlefield Rhyolite pyroxene phenocrysts. Upper Littlefield Rhyolite sample number: BW-14-67.........54

Table 5: Composition of titanomagnetite phenocrysts in sample BW-14-67, including small amounts of $\mathrm{Mg}$ and $\mathrm{Mn}$. *Solid-solution of $\mathrm{FeO}$ and $\mathrm{Fe}_{2} \mathrm{O}_{3}$ .55

Table 6: The average, minimum, and maximum calculated end-member compositions from electron Microprobe (EMP) analyses of lower Littlefield Rhyolite feldspar phenocrysts. Lower Littlefield Rhyolite sample number: BW-14-19..........58

Table 7: The average, minimum, and maximum calculated end-member compositions from electron Microprobe (EMP) analyses of lower Littlefield Rhyolite pyroxene phenocrysts. Lower Littlefield Rhyolite sample number: BW-14-19. .......59 
Table 8: The average, minimum, and maximum composition of titanomagnetite phenocrysts derived from electron microprobe analyses. *Solid-solution of $\mathrm{FeO}$ and $\mathrm{Fe}_{2} \mathrm{O}_{3}$. .59

Table 9: Single crystal ${ }^{40} \mathrm{Ar} /{ }^{39} \mathrm{Ar}$ dates for the upper Littlefield Rhyolite, lower Littlefield Rhyolite, rhyolite of Bully Creek Canyon, and rhyolite of Cottonwood Mountain. See the appendix for ${ }^{40} \mathrm{Ar} /{ }^{39} \mathrm{Ar}$ sample locations and detailed results of ${ }^{40} \mathrm{Ar} /{ }^{39} \mathrm{Ar}$ sample analysis. Two separate analyses of sample BW-13-02 were performed and both produced questionable ages and unacceptable errors. *denotes repeat analysis

Table 10: The average, minimum, and maximum wt.\% major element composition of 12 samples of Hunter Creek Basalt, including trace element concentrations of Ba (ppm). 67

Table 11: The average, minimum, and maximum calculated end-member compositions from electron Microprobe (EMP) analyses of epiclastic tuff sanidine phenocryst phases. Epiclastic tuff sample number: BW-14-12 .73

Table 12: The average, minimum, and maximum calculated end-member compositions from electron Microprobe (EMP) analyses of Dinner Creek Tuff pyroxene phenocrysts. .79

Table 13: The average, minimum, and maximum calculated end-member compositions from electron Microprobe (EMP) analyses of Dinner Creek Tuff feldspar phenocrysts 80

Table 14: Average major element compositions of upper Littlefield Rhyolite (LFR) $(n=6)$, commonly observed ( $\sim 55$ wt. $\left.\% \mathrm{SiO}_{2}\right)$ Hunter Creek Basalt (HCB) $(n=12)$, icelandite of Alder Creek Canyon, and the calculated result of mixing 55.12\% Hunter Creek Basalt magma with 44.88\% upper Littlefield Rhyolite magma. The calculated major element composition resulting from magma mixing closely resembles icelandite of Alder Creek Canyon, with the exception of wt.\% Mg0, which is notably higher in the mixing calculation .91 


\section{LIST OF FIGURES}

Figure 1: Map shows the extent of Columbia River Flood Basalts and associated dikes. Main phase Columbia River Basalt outpourings of Steens, Imnaha, and Grande Ronde, erupted progressively from south to north through a migrating series of dikes associated with the Steens (Steens Basalt) and Chief Joseph (Imnaha Basalt followed by Grande Ronde Basalt) swarms. Modified map from Camp \& Ross (2004).

Figure 2: Time progressive map series showing areal emplacement of Steens Basalt (dark-green), followed by Imnaha Basalt (light-green), which is then followed by outpourings of Grande Ronde Basalt (blue). Modified maps based on Camp \& Ross (2004)

Figure 3: Map shows the approximate alignment of the Littlefield Rhyolite along the N-NE trending Squaw Creek Fault Zone that forms the northwestern margin of the Oregon-Idaho Graben (Cummings et al., 2000). The W-NW trending Adrian Fault Zone forms the northern extent of the graben, separating it from the Western Snake River Plain located to the North.

Figure 4: Map shows the extent of the original geological mapping of the Owyhee region compiled by Kittlemen et al. (1967). United States Geological Survey 7.5 minute quadrangle boundaries with labeled lines of latitude have been added for reference. Map datum and projection is NAD83, Oregon Statewide Lambert.

Figure 5: Map shows the distribution of additional geological units that were initially mapped as belonging to the Littlefield Rhyolite by Kittlemen et al. (1967). United States Geological Survey 7.5 minute quadrangle boundaries with labeled lines of latitude have been added for reference. Map datum and projection is NAD83, Oregon Statewide Lambert. Compiled geological mapping GIS data is courtesy of the Oregon Department of Geology and Mineral Industries (Ma et al., 2009). 16

Figure 6: Mapping of select 7.5' quadrangles were performed during the 1990's, when individual workers began to identify and distinguish an additional, underlying rhyolite unit that had been previously mapped as the Littlefield Rhyolite by 
Kittleman et al. (1967). Unpublished mapping performed north of the $44^{\text {th }}$ parallel (Evans (1995a; 1995b) revealed extensive rhyolite exposures around Cottonwood Mountain. Note that all mapping north of the $44^{\text {th }}$ parallel remains currently unpublished.

Figure 7: Plot of $\mathrm{Zr}$ (ppm) versus TiO2 (wt.\%) shows distinct geochemical differences between the lithologically and petrographically similar overlying and underlying rhyolite units. The underlying rhyolite unit has been denoted as the Littlefield Rhyolite (Kittleman et al., 1965, 1967), the Lower Littlefield Rhyolite (Lees, 1994), the Rhyolite of Cottonwood Mountain (Hooper, et al., 2004; Cummings, et al., 2000) and the Rhyolite of Bully Creek Canyon (Brooks \& O'Brien, 1990)). The overlying rhyolite unit has been called the Littlefield Rhyolite by all authors. XRF data is from Hooper et al. (2002). 20

Figure 8: Plot shows $\mathrm{Nb}$ (ppm) versus $\mathrm{Zr}$ (ppm) concentrations for 57 combined samples of Upper Littlefield Rhyolite and Lower Upper Littlefield Rhyolite obtained from pXRF analysis (shown in grey), and compared to ICP-MS analysis of a subset of these samples (upper Littlefield Rhyolite shown in burgundy; lower Littlefield Rhyolite shown in red). 24

Figure 9: Overview map showing the three areas of interest where transects were performed. 26

Figure 10: The dashed line highlights the primary transect that was performed at Namorf, within the eastern extent Malheur River Gorge. The $\sim 280 \mathrm{~m}$ thick series of stratigraphic units exposed here were initially mapped as Littlefield Rhyolite by Kittleman et al. (1967), and later by Ferns and O'Brien (1992a). Photo location coordinates are $440150 \mathrm{mE}, 4848741 \mathrm{mN}$. Projection and datum are UTM 11N, NAD83. Center of photograph is facing South-Southeast. 27

Figure 11: Image shows the $\sim 280 \mathrm{~m}$ thick exposures of interest for the primary transect performed at Namorf, within the eastern extent of the Malheur River Gorge. The stratigraphic sequence viewed here is mapped as Littlefield Rhyolite (Kittleman et al., 1967; Ferns and O'Brien, 1992). Image is taken looking south from a point bar obscuring view of the Malheur River. 28 
Figure 12: N-NW facing exposures along the Malheur River with 280 meters of steep relief. The transect revealed a variety of additional units sandwiched between two extensive rhyolite lavas.

Figure 13: Photograph showing the location where the base of the lower Littlefield Rhyolite is exposed. 30

Figure 14: The image above shows a depositional layered agglutinated pyroclastic deposit, which thins rapidly to $<2 \mathrm{~m}$ in exposures located on the opposite side of the river. The unit is composed of agglutinated basaltic andesite, and is compositionally similar to Hunter Creek Basalt. In this case, the source of this particular deposit would have likely been a vent located somewhere to the left of the image. Epiclastic tuff talus overlies the unit in scattered areas.

Figure 15: Light-colored epiclastic tuff as observed along the primary transect. The base of the overlying unit shown here is the middle Hunter Creek Basalt lava flow.32

Figure 16: Photograph shows the epiclastic tuff sandwiched between Hunter Creek Basalt units. The Hunter Creek agglutinate is relatively thin in the transect $(\sim 1.5 \mathrm{~m})$.

Figure 17: Image shows the middle and the upper Hunter Creek Basalt lavas, including a thin baked-zone along the top of the middle lava flow. Basal breccia of the upper Littlefield Rhyolite is visible in the distance. 34

Figure 18: Images shows the exposed base of the upper Littlefield Rhyolite. A thin, moderately-welded tuff overlies surge deposits, and underlies basal breccia of the upper Littlefield Rhyolite. One of the age dates for the upper rhyolite was acquired using a glassy sample of rhyolite breccia from this location. 35

Figure 19: Map showing the north side of the Malheur River at Namorf. Silicified, fault-brecciated outcrops of upper Littlefield Rhyolite form linear, relatively thin 
and tall features that rise out of the talus dominated slopes and can be traced for kilometers. Map is comprised of a bare-earth lidar derivative overlain with NAIP orthoimagery. Map projection and datum is Oregon Statewide Lambert, NAD 83 HARN. Lidar data is courtesy of the Oregon Lidar Consortium.

Figure 20: Photo shows proximal and distal silicified fault outcroppings observed in the upper Littlefield Rhyolite. Direction of photo is to the south-southwest. 37

Figure 21: Map shows Hunter Creek Basalt and lower Littlefield Rhyolite vents within the Malheur River Gorge. Hunter Creek vent location is inferred based upon pyroclastic bedding and changes in unit thickness with distance. Vents are roughly aligned along the north striking Hog Creek Fault Zone. Map projection and datum is Oregon Statewide Lambert, NAD 83 HARN. Lidar data is courtesy of the Oregon Lidar Consortium.

Figure 22: Image taken from the top of Hog Creek Ridge, looking west towards Westfall Butte. 40

Figure 23: Orthoimagery showing exposures of the lower Littlefield Rhyolite. Relative uplift on the north side of the fault has placed the Hunter Creek Basalt topographically adjacent to the upper Littlefield Rhyolite. The lower Littlefield Rhyolite has been exposed in areas where erosion of the overlying Hunter Creek Basalt has been relatively more pronounced. 41

Figure 24: Image taken near Negro Rock Reservoir, looking E-NE. Exposures of the uppermost flow section (vitrophyre) of lower Littlefield Rhyolite appear in drainages and other areas of increased erosion of the overlying Hunter Creek Basalt.

Figure 25: View looking north at the start of the Alder Creek Canyon transect, heading downslope into Alder Creek Canyon. The upper Littlefield Rhyolite gently dips towards the south here and can be seen in the distance on the north side of Cottonwood Canyon, where it eventually is overlain by younger mafic lavas. 42 
Figure 26: Image shows a rarely observed exposure of Dinner Creek Tuff observed in Alder Creek Canyon. The Dinner Creek Tuff forms a poorly-welded pyroclastic deposit that is relatively thick given its distance from the presumed source area... 43

Figure 27: View looking south and upslope within Alder Creek Canyon. The upper Littlefield Rhyolite crops out here. The icelandite lava forms steep, talus dominated slopes that obscure outcrop, including outcrop of the underlying Dinner Creek Tuff.

Figure 28: Photograph shows the glassy base of the upper Littlefield Rhyolite, overlying a thin, moderately-welded tuff. Littlefield Rhyolite basal breccia is absent in the south, which likely explains why the underlying tuff is better preserved here, compared to the violence inflicted on the underlying tuff that is observed at Namorf.

Figure 29: Image shows the base of the upper Littlefield Rhyolite observed within the Malheur River Gorge. A thick section of basal autobreccia overlies a thin lens of dacitic welded tuff, which overlies pyroclastic surge deposits. Some of the lightcolored tuffaceous material was abraided during emplacement of the overriding lava flow and incorporated into the matrix of the basal breccia.. 45

Figure 30: Total Alkali Silica diagram for XRF samples collect for this study 46

Figure 31: Rhyolite Flow units are distinguished by $\mathrm{Zr}, \mathrm{Ba}, \mathrm{Nb}, \mathrm{TiO} 2$ and $\mathrm{FeO}$ concentrations. The overlying unit possesses relatively higher concentrations of Zirconium, Niobium, and Barium, along with relatively lower concentrations of $\mathrm{TiO}_{2}$ $(\sim 0.4$ wt. $\%)$. 48

Figure 32: Primitive mantle-normalized element composition of the upper and lower Littlefield rhyolites. The upper Littlefield Rhyolite has relatively higher concentrations of most trace elements, with the exception of $\mathrm{Ti}, \mathrm{P}, \mathrm{Sr}, \mathrm{Pb}, \mathrm{K}, \mathrm{U}, \mathrm{Th}$, and $\mathrm{Rb}$. The less incompatible elements appear to follow a similar trend, which is not as apparent between elements of increased incompatibility. Normalization values from Sun \& McDonough (1989). 49 
Figure 33: C1-normalized REE compositions of the upper and lower Littlefield rhyolites. The upper Littlefield Rhyolite has relatively higher concentrations of rareearth elements (REE) and less depletion of Eu. Normalization values from Sun \& McDonough (1989).

Figure 34: Th/Ta generally increases with increasing crustal contamination. The plot of Th/Ta versus La/Ta shows that lower Littlefield Rhyolite appears relatively distinct from the upper Littlefield Rhyolite. Additionally, upper Littlefield Rhyolite appears similar to the Hunter Creek Basalt and icelandite of Alder Creek Canyon. This suggests that the upper and lower Littlefield Rhyolites have distinct petrogenetic histories. 50

Figure 35: Photograph of an upper Littlefield Rhyolite outcrop showing columnar jointing above basal autobreccia. 51

Figure 36: Ternary plot shows the range of calculated end-member compositions from electron Microprobe (EMP) analyses of upper Littlefield Rhyolite feldspar phenocrysts. Upper Littlefield Rhyolite sample number: BW-14-67. 53

Figure 37: Ternary plot shows the range of calculated end-member compositions from electron Microprobe (EMP) analyses of upper Littlefield Rhyolite pyroxene phenocrysts. Upper Littlefield Rhyolite sample number: BW-14-67. 54

Figure 38: Photomicrographic image of upper Littlefield Rhyolite, showing feldspar, pyroxene, and titanomagnetite phenocrysts, within a vitric groundmass containing scattered crystallites. 55

Figure 39: Photograph of a platey-jointed outcrop of lower Littlefield Rhyolite overlooking the Malheur River. 56

Figure 40: Ternary plot shows the range of calculated end-member compositions from electron Microprobe (EMP) analyses of lower Littlefield Rhyolite feldspar phenocrysts. Lower Littlefield Rhyolite sample number: BW-14-19. 58 
Figure 41: Ternary plot shows the range of calculated end-member compositions from electron Microprobe (EMP) analyses of lower Littlefield Rhyolite pyroxene phenocrysts. Lower Littlefield Rhyolite sample number: BW-14-19. 59

Figure 42: Photomicrographic image of lower Littlefield Rhyolite, showing feldspar and pyroxene phenocrysts within a vitric groundmass containing scattered crystallites. 60

Figure 43: Photomicrographic image of lower Littlefield Rhyolite, showing browncolored melt inclusions that are commonly observed within feldspar phenocrysts. Vitric groundmass contains scattered crystallites. 60

Figure 44: SEM imagery highlights the presence of apatite within a lower Littlefield Rhyolite sample. A back-scatter Electron (BSE) image on the left shows titanium magnetite, pyroxene, and feldspar phenocrysts surrounded by a matrix of glass and crystallites. Feldspar appears to be in equilibrium with the surrounding groundmass. A cathode-luminescence image on the right highlights numerous, trace-element rich, apatite microlites. 61

Figure 45: Correlations between main phase Columbia River Basalt Group lavas and the stratigraphy exposed in the Malheur River Gorge. Modified figure based on Wolff et al. (2008). 63

Figure 46: Photomicrographic image of the lower Hunter Creek Basalt lava at the primary transect within the Malheur River Gorge. 65

Figure 47: Photomicrographic image of the middle Hunter Creek Basalt lava at the primary transect within the Malheur River Gorge. 65

Figure 48: Photomicrographic image of the upper Hunter Creek Basalt lava at the primary transect within the Malheur River Gorge. 66 
Figure 49: Photomicrographic image of agglutinated spatter of Hunter Creek Basalt. The groundmass is composed of welded shards of basaltic andesite glass, which appears opaque in both plain and cross polarized light. Scattered, sparsely cumulophyric microphenocrysts of feldspar and clinopyroxene are visible.

Figure 50: Plot of Ba (ppm) versus FeO (wt.\%) for Hunter Creek Basalt samples. ... 68

Figure 51: Primitive mantle-normalized elemental composition of two samples of icelandite of Alder Creek Canyon lavas $\left(\sim 63 \mathrm{wt} . \% \mathrm{SiO}_{2}\right)$, compared to the average composition of commonly observed Hunter Creek Basalt lavas ( $\sim 55$ wt. $\% \mathrm{SiO}_{2}$ ). With the exception of $\mathrm{Ba}$, the range of compositions of Hunter Creek Basalt samples is sufficiently narrow, and the average composition is shown here for simplicity. The plot suggests that icelandite and Hunter Creek compositions may be petrogenetically related, with the icelandite showing similar increases or decreases in trace element concentrations relative to Hunter Creek Basalt. Nevertheless, icelandite of Alder Creek Canyon and Hunter Creek Basalt lavas are geochemically distinct units. 69

Figure 52: Photomicrographic image of Icelandite of Alder Creek Canyon, showing aphanitic texture and rare phenocrysts of tabular feldspar.

Figure 53: Photomicrographic image of dacitic welded tuff that underlies the upper Littlefield Rhyolite at the primary transect at Namorf. The unit is also observed underlying the upper Littlefield Rhyolite in Alder Creek Canyon. 71

Figure 54: Ternary diagram shows the average feldspar end-member composition of the epiclastic tuff.

Figure 55: Photomicrographic image of the epiclastic tuff, showing sandine and quartz phenocrysts in a eutaxic matix. Scattered, fractured, angular grains of sanidine and quartz strongly resemble each other when viewed under crosspolarized light, making a reliable determination of their relative abundances uncertain. 73 
Figure 56: Elemental composition of two samples of the epiclastic tuff that overlies the Hunter Creek Basalt agglutinate at Namorf, compared with the average compositions of the four Dinner Creek Tuff (DIT) eruptive units identified by Streck et al. (2015). DIT geochemical data is from Streck et al. (2015). The epiclastic tuff has significantly less $\mathrm{Ba}$ and Eu compared to the Dinner Creek ignimbrites. 75

Figure 57: REE compositions of two samples of the epiclastic tuff that overlies the Hunter Creek Basalt agglutinate at Namorf, compared with the average compositions of the four Dinner Creek Tuff eruptive units identified by Streck et al. (2015). Though the overall REE compositions are similar, the epiclastic tuff has significantly less europium. Dinner Creek Tuff geochemical data is from Streck et al. (2015). 75

Figure 58: Plot shows the average compositions of Dinner Creek Tuff units 1-4 of Streck et al. (2015), compared to Dinner Creek Tuff sample BW-14-45. Normalization values from Sun \& McDonough (1989). 77

Figure 59: Plot shows the average REE compositions of Dinner Creek Tuff units 1-4 of Streck et al. (2015), compared to Dinner Creek Tuff sample BW-14-45. Normalization values from Sun \& McDonough (1989). 78

Figure 60: The average, minimum, and maximum calculated end-member compositions from electron Microprobe (EMP) analyses of Dinner Creek Tuff pyroxene phenocrysts. Dinner Creek Tuff sample BW-14-45 is petrographically and stratigraphically distinct from the formally recognized Dinner Creek Tuff unit that is mapped throughout the Malheur River Gorge.

Figure 61: The average, minimum, and maximum calculated end-member compositions from electron Microprobe (EMP) analyses of Dinner Creek Tuff feldspar phenocrysts. Dinner Creek Tuff sample BW-14-45 is petrographically and stratigraphically distinct from the formally recognized Dinner Creek Tuff unit that is mapped throughout the Malheur River Gorge. 80

Figure 62: Photomicrographic image of sample BW-14-45, showing a pyroxene phenocryst. Pyroxene is rarely observed in other Dinner Creek Tuff units. Image is 
taken using plain-polarized light. Sample is geochemically equivalent to Dinner Creek Tuff unit 1, but is stratigraphically and petrographically distinct. Stratigraphic position of sample source is currently unknown, but emplacement followed that of the commonly observed Dinner Creek Tuff at Namorf. 81

Figure 63: Characteristic features of Snake River-type rhyolite lavas contrasted with those typical of other volcanic regions. Snake River-type lavas are much more voluminous, more extensive, and have lower aspect ratios than 'typical' non-Snake River-type lavas. Modified figure is from Branney, et al. (2007). 84

Figure 64: Primitive mantle-normalized, average elemental compositions of Hunter Creek and Birch Creek samples, compared to the average composition $( \pm 2 \sigma)$ of 39 samples of Grande Ronde Basalt. Hunter Creek and Birch Creek units have relatively higher concentrations of incompatible elements, consistent with late-stage Grande Ronde magmatism. Grande Ronde Basalt geochemical data are from Wolff et al. (2008). Normalization values from Sun \& McDonough (1989). 86

Figure 65: Primitive mantle-normalized, elemental composition of a sample of basalt Malheur Gorge (upper Pole Creek formation), compared to the average composition $( \pm 1 \sigma)$ of 51 samples of Imnaha Basalt. Imnaha Basalt geochemical data are from Wolff et al. (2008). Normalization values from Sun \& McDonough (1989).

Figure 66: Primitive mantle-normalized, elemental composition of a sample of basalt of Malheur Gorge (lower Pole Creek formation), compared to the average composition $( \pm 1 \sigma)$ of 61 samples of Steens Basalt. Steens Basalt geochemical data are from Wolff et al. (2008). Normalization values from Sun \& McDonough (1989).

Figure 67: Primitive mantle-normalized elemental composition profiles of two samples of icelandite of Alder Creek Canyon that was collected from the southern transect. The icelandite unit is mapped as Hunter Creek Basalt, given its stratigraphic position. The grey-colored profile shows the average composition of ten samples of Hunter Creek Basalt $\left(\sim 55 \mathrm{wt} . \% \mathrm{SiO}_{2}\right)$. The dark red-colored profile shows the average composition of upper Littlefield Rhyolite, which overlies either 
Hunter Creek Basalt (in the north), or icelandite of Alder Creek Canyon (in the south). Primitive mantle normalization values from Sun \& McDonough (1989)....... 89

Figure 68: Plot shows the calculated result of mixing upper Littlefield Rhyolite and Hunter Creek Basalt magmas. The calculated results closely match the trace element composition of the icelandite observed in Alder Creek Canyon....................................... 90 


\section{CHAPTER 1: INTRODUCTION}

During the middle Miocene, voluminous tholeiitic flood basalts erupted in eastern Oregon, followed closely by widespread eruptions of rhyolitic tuffs and lavas. While numerous causes have been proposed, and although much of the details are still being worked out, many researchers are currently in agreement that the initiation of a mantle plume associated with the Yellowstone hotspot track is broadly responsible for this magmatic activity (Cummings et al., 2000; Hooper et al., 2002). Following the production of tholeiitic magmas, widespread silicic magmatism resulted either from partial melting of silicic crustal material, or due to fractional crystallization of the tholeiitic magmas. The basaltic component of this magmatic activity has received considerable attention from investigators, whereas the corresponding silicic volcanism has received disproportionately less attention (Cummings et al., 2000).

The focus of this study is to document the stratigraphy of large, hotspot-related rhyolite lava flows of the Pacific NW: The Littlefield Rhyolite, Eastern Oregon. While the areal extent and distribution of the Littlefield Rhyolite has been sufficiently delineated by geological mapping, there is surprisingly little known about the internal stratigraphy, distribution of individual flows, emplacement mechanisms, age, and potential relationship with time-correlative mafic magnetism.

The greater Malheur River Gorge area contains intercalated stratigraphy of earlier main-phase Columbia River Basalt lavas that are geochemically and stratigraphically 
correlated with Steens, Imnaha, and Grande Ronde Basalt lavas (Binger, 1997; Lees, 1994; Camp et al., 2003; Hooper et al., 2002), then transitioning to locally erupted Hunter Creek Basalt lavas that are geochemically similar to late-stage Grande Ronde Basalt.

Locally erupted lava flows and pyroclastic deposits of Hunter Creek Basalt (tholeiitic basaltic andesite) are geochemically similar to late stage Grande Ronde Basalt and are associated in time and space with eruptions of high-volume, widespread rhyolitic lavas within the Malheur River Gorge. Two of these widespread rhyolitic lavas are often indistinguishable in the field, and were originally mapped as the Littlefield Rhyolite by Kittleman et al. (1967). These two rhyolites are herein referred to as upper Littlefield Rhyolite and lower Littlefield Rhyolite, based on their relative stratigraphic positions observed in the Malheur River Gorge. 


\section{CHAPTER 2: BACKGROUND}

\section{Geological Setting}

\section{Main Phase Columbia River Basalt Group (CRBG)}

The main phases of the Columbia River Basalt Group (CRBG) erupted between 16.7 and 16.0 Ma, primarily consisting of the Steens, Imnaha, and Grande Ronde Basalt, which appear to have erupted progressively from south to north through a migrating series of dikes associated with the Steens and Chief Joseph dike swarms (Figure 1). Contemporaneous with Grande Ronde activity, subsidiary eruptions of Picture Gorge Basalt occurred further to the west (Barry et al., 2013; Camp \& Ross, 2004; Camp et al., 2003; Wolff and Ramos, 2008; Ramos et al., 2013).

Main phase CRBG volcanism began in southeastern Oregon with fissure eruptions of lower Steens Basalt, followed by the more-voluminous upper Steens Basalt. Upper Steens Basalt eruptions were contemporaneous with the initial outpourings of Imnaha Basalt as the vents progressed northward, west of, and parallel to, the Paleozoic craton boundary, and ending with Grande Ronde eruptions associated with the Chief Joseph dike swarms (Figure 2) (Barry et al., 2013; Camp \& Ross, 2004; Camp et al., 2003; Wolff and Ramos, 2008; Ramos et al., 2013). 


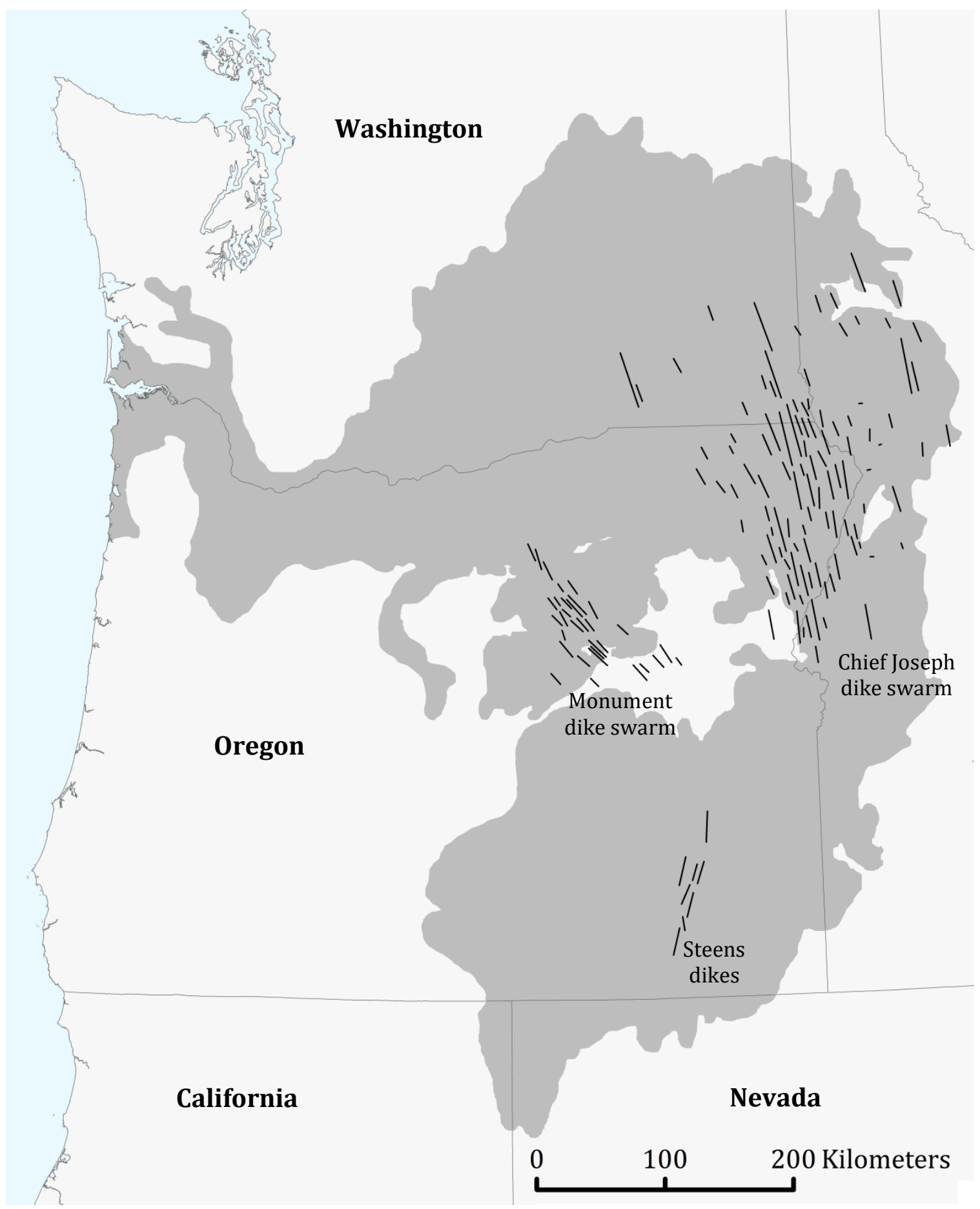

Figure 1: Map shows the extent of Columbia River Flood Basalts and associated dikes. Main phase Columbia River Basalt outpourings of Steens, Imnaha, and Grande Ronde, erupted progressively from south to north through a migrating series of dikes associated with the Steens (Steens Basalt) and Chief Joseph (Imnaha Basalt followed by Grande Ronde Basalt) swarms. Modified map from Camp \& Ross (2004). 


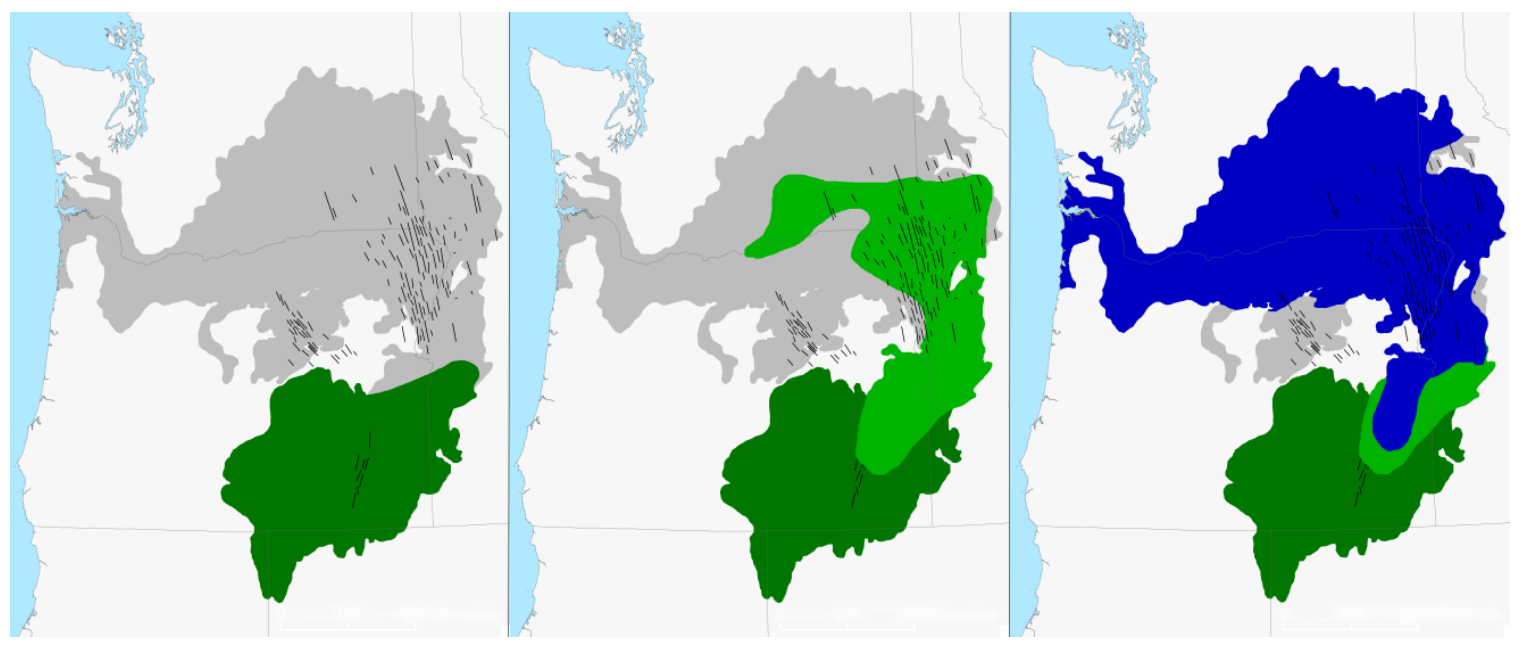

Figure 2: Time progressive map series showing areal emplacement of Steens Basalt (darkgreen), followed by Imnaha Basalt (light-green), which is then followed by outpourings of Grande Ronde Basalt (blue). Modified maps based on Camp \& Ross (2004).

The Imnaha Basalt has a volume of $\sim 11,000 \mathrm{~km}^{3}$ (Reidel et al., 2013), displays significant variations in major- and trace-element concentrations, and is considered by Wolff \& Ramos (2008) and Ramos et al. (2013) to represent the primary, mantlesourced, geochemical component that is present in all main-phase Columbia River Basalt Group (CRBG) lavas. Imnaha lavas possess many of the geochemical features of depleted mantle-Ocean Island Basalt (OIB) (Hooper et al., 2007), likely enriched with minor crustal contamination, and possibly include an additional component of fluid-enriched-arc mantle (Wolff and Ramos, 2008; Ramos et al., 2013).

Steens Basalt has a volume of $\sim 31,800 \mathrm{~km}^{3}$ (Camp et al., 2013), with well-exposed stratigraphy at the eastern slope of Steens Mountain, southeast Oregon. The lower Steens stratigraphy consists of more-primitive, tholeiitic lavas, while the upper Steens stratigraphy contains unusually more-evolved lavas, relative to other CRBG lavas. Wolff \& Ramos (2008) and Ramos et al. (2013) conclude that Steens Basalt 
lavas result from a mixture of Imnaha-source melt with a greater proportion of Mid Ocean Ridge Basalt (MORB) source mantle. This MORB-source component decreased with time, with the lower Steens lavas having a greater proportion relative to the upper Steens lavas, which contains a relatively higher proportion of the Imnaha component. Additionally, Steens lavas contain weak correlations between radiogenic isotopes and Large Ion Lithophile Elements (LILE)/High Field Strength Element (HFSE) ratios, which suggest a minor additional component from either subduction-related contamination of the mantle source (Wolfe and Ramos, 2013), or direct contamination of Steens magmas by an accreted terrane crustal component (Ramos et al., 2013).

Picture Gorge Basalt has a volume of $\sim 2400 \mathrm{~km}^{3}$ (Reidel et al., 2013) and was erupted from the Monument dike swarm in central Oregon, contemporaneous with the outpouring of Grand Ronde flows further to the east. The composition of Picture Gorge lavas can be modeled similar as the Steens, in that their source material suggests a mixture of depleted mantle with the Imnaha constituent component. Nevertheless, Picture Gorge lavas have been proposed to remain unique among the CRBG by being the result of a separate magmatic system derived from a mixture of distinct, back-arc mantle components (Wolff and Ramos, 2013). Picture Gorge Basalt is not a relevant main-phase CRBG unit when discussing mid-Miocene units observed within the Malheur River Gorge, and will not be mentioned further. 
Grande Ronde Basalt has a volume of $\sim 150,400 \mathrm{~km}^{3}$, representing $\sim 71 \%$ of the combined, main-phase CRBG (Reidal and Tolan, 2013). Grande Ronde lavas are texturally distinct from the earlier, coarse-grained Imnaha and Steens lavas, being predominantly aphyric, tholeiitic basaltic andesites. Grande Ronde lavas often contain glass in their groundmass, suggesting that Grande Ronde units were frequently erupted at superliquidus temperatures.

Wolff et al. (2008) have shown that Grande Ronde Basalt geochemistry can be modeled as the result of contamination of Imnaha Basalt magmas by cratonic crust, given that Grande Ronde trace element compositions form a continuum with Imnaha Basalt, and that Paleozoic-age accreted arc terranes are too young to provide the low ${ }^{143} \mathrm{Nd} /{ }^{144} \mathrm{Nd}$ ratio required by the crustal contaminant. Wolff and Ramos (2013) consider Imnaha and Grande Ronde to be derived from a single centralized crustal magmatic system, which evolved due to increasing thermal input that incorporated increasing amounts of crustal melts (Wolfe et al., 2008).

\section{The Malheur River Gorge: Crossroads of Main Phase CRBG Emplacement}

One of the problems with this area of Oregon is the stratigraphic naming. Many of the earliest names of Kittleman et al. $(1965,1967)$ grouped, divided, or misidentified units in ways that have turned out to be problematic for later workers. Nevertheless, these early names are preserved in the literature (Cummings, personal communication). Most of the formally named units in eastern central and southeastern Oregon, including the Littlefield Rhyolite, are tied to the initial work of Kittleman et al. $(1965,1967)$. Many of these early unit names and divisions have not 
served well for later workers, many of whom subsequently introduced additional informal names, which have better served to designate individual units and bracket stratigraphic divisions, but at the cost of an increasingly complicated and overlapping nomenclature.

The Malheur River Gorge is approximately situated in between the Steens and Chief Joseph dike swarms, and contains a stratigraphic record of main-phase CRBG volcanism capturing intercalated stratigraphies from well-established, continuous CRBG stratigraphy to the north and south. What is interesting about the Malheur River Gorge is that following the emplacement of main phase CRBG lavas from distal vents, local eruptions of rhyolites occurred in conjunction with local eruptions of Hunter Creek Basalt (tholeiitic basaltic andesite), which is geochemically and petrographically similar to, and contemporaneous with, late-stage Grande Ronde Basalt.

Additionally, icelandite lavas erupted within the Malheur River Gorge area as well, and appear to be the result of magma mixing between rhyolitic and tholeiitic magmas.

\section{Basalt of Malheur Gorge}

Named by Evans (1990a, 1990b), formally called "unnamed igneous complex" of Kittleman, et al. (1965), and equivalent to "western tholeiitic lavas" of Ferns, et al. (1993a), the basalt of Malheur Gorge is a thick (800 - 1100 meter) stratigraphic sequence of tholeiitic lavas that are exposed throughout the Malheur River Gorge 
(Cummings et al., 2000; Hooper et al., 2002). Lees (1994) divided the sequence of units into three formations based upon petrography and geochemistry. The lower Pole Creek formation denotes the lowest stratigraphic units, which are notably course-grained and plagioclase phyric (20-40\%). Lower Pole Creek units typically weather to form dark-brown, coarse-grained, sand- and gravel-sized colluvium, in contrast to the overlying tholeiitic units that weather to form blocky, dark-colored talus. The upper Pole Creek formation forms the central stratigraphic section and is moderately to sparsely phyric. The Birch Creek formation denotes the uppermost stratigraphic units, which are typically aphyric, and commonly contain interstitial glass. However, some of the lower Birch Creek lavas can display subtle texture that is just barely visible to the unaided eye.

Work by Binger (1997) and Lees (1994) has shown that basalt of Malheur Gorge internal stratigraphy is dominated by Pole Creek lavas in the south, while Birch Creek lavas are more numerous to the north and northeast, in the areas surrounding Brogen, Oregon. Prior studies by Binger (1997), Lees (1994), Hooper, et al. (2002), and Camp, et al. (2003) suggests that the sequence of basalt of Malheur Gorge is stratigraphically, petrographically, chronologically, and geochemically equivalent to Steens Basalt (lower Pole Creek units), Imnaha Basalt (upper Pole Creek units), and Grande Ronde Basalt (Birch Creek and Hunter Creek units) lavas of the Columbia River Basalt Group. 


\section{Onset of Bimodal Volcanism--The Hog Creek Formation}

Overlying the basalt of Malheur Gorge is a package of units known as the Hog Creek formation of Lees (1994); a sequence of distinctly bimodal lavas and tuffs, which include the Dinner Creek Tuff, the lower Littlefield Rhyolite, the Hunter Creek Basalt, and the upper Littlefield Rhyolite (Lees, 1994; Cummings et al., 2000; Hooper et al., 2002). The silicic members of the Hog Creek formation display distinct trace element concentrations and no geochemical trend toward higher incompatible element concentrations. This suggests that these units were not derived from a basaltic parent along a single fractionation trend, but rather were likely derived from distinct crustal sources (Hooper et al., 2003).

The Hunter Creek Basalt is a Fe-rich basaltic andesite unit presenting late-stage eruption of tholeiitic volcanism within the Malheur River Gorge area. The Hunter Creek Basalt lies stratigraphically above the Dinner Creek Tuff (Lees, 1994; Hooper, et al., 2003), or above the lower Littlefield Rhyolite, if present. There is evidence that Hunter Creek lavas erupted shortly after the Dinner Creek Tuff (Evans, 1990; Cummings et al., 2000; Camp et al., 2003, Streck et al., 2015) and that these two units are petrogenetically related (Streck et al., 2015). Hunter Creek Basalt lavas are lithologically, petrographically, and geochemically similar to Birch Creek lavas. Hunter Creek Basalt is stratigraphically differentiated from Birch Creek units by the presence of the Dinner Creek Tuff, which is commonly a well-defined, laterally continuous, cliff-forming marker that stratigraphically separates these units. 
Additionally, Hunter Creek Basalt lavas erupted locally, while Birch Creek lavas may have erupted from distal vents.

Littlefield rhyolites were emplaced along the northwestern shoulder of the OregonIdaho graben. East-west extensional processes associated with the formation of the

Oregon-Idaho Graben coincide with eruptions of the Columbia River Basalts, and were continuing to occur in the Malheur River Gorge area during the emplacement of the Hog Creek units (Cummings et al., 2000), leading to right-lateral and vertical offset faulting of the Dinner Creek Tuff, Hunter Creek Basalt, and upper Littlefield Rhyolite. Initial faulting and displacement that occurred along the Hog Creek fault coincides with the locations of lower Littlefield Rhyolite vents, and may have constrained the emplacement of the lower Littlefield Rhyolite.

Following a brief hiatus in the outpouring of hotspot related tholeiitic and bimodal volcanism, numerous small-volume eruptions of calc-alkaline basaltic volcanism was initiated within the Oregon-Idaho graben. These later units, which conformably overlie the faulted Hog Creek units, are associated with a change from plume-related magmatism to extension-related magmatism (Lees, 1994).

\section{The Littlefield Rhyolite}

The Littlefield Rhyolite belongs to numerous rhyolitic lavas and tuffs that erupted in Eastern Oregon during the middle Miocene, contemporaneous or immediately following widespread outpouring of hot-spot related, tholeiitic, continental floodbasalt (Cummings et al., 2000; Hooper et al., 2002; Lees, 1994; Streck et al., 2015). 
The Littlefield Rhyolite forms an unusually voluminous and extensive silicic lava flow, some of which was emplaced along the northwestern margin of the OregonIdaho graben (Cummings et al., 2000) (Figure 3). Earlier estimates place the total volume of erupted magma at $100 \mathrm{~km}^{3}$ with an outcrop distribution covering approximately 850 km² (Ferns et al., 1993; Streck and Ferns, 2004). Exposures are greater than 175 meters in thickness and are best observed in the Malheur River Gorge. 


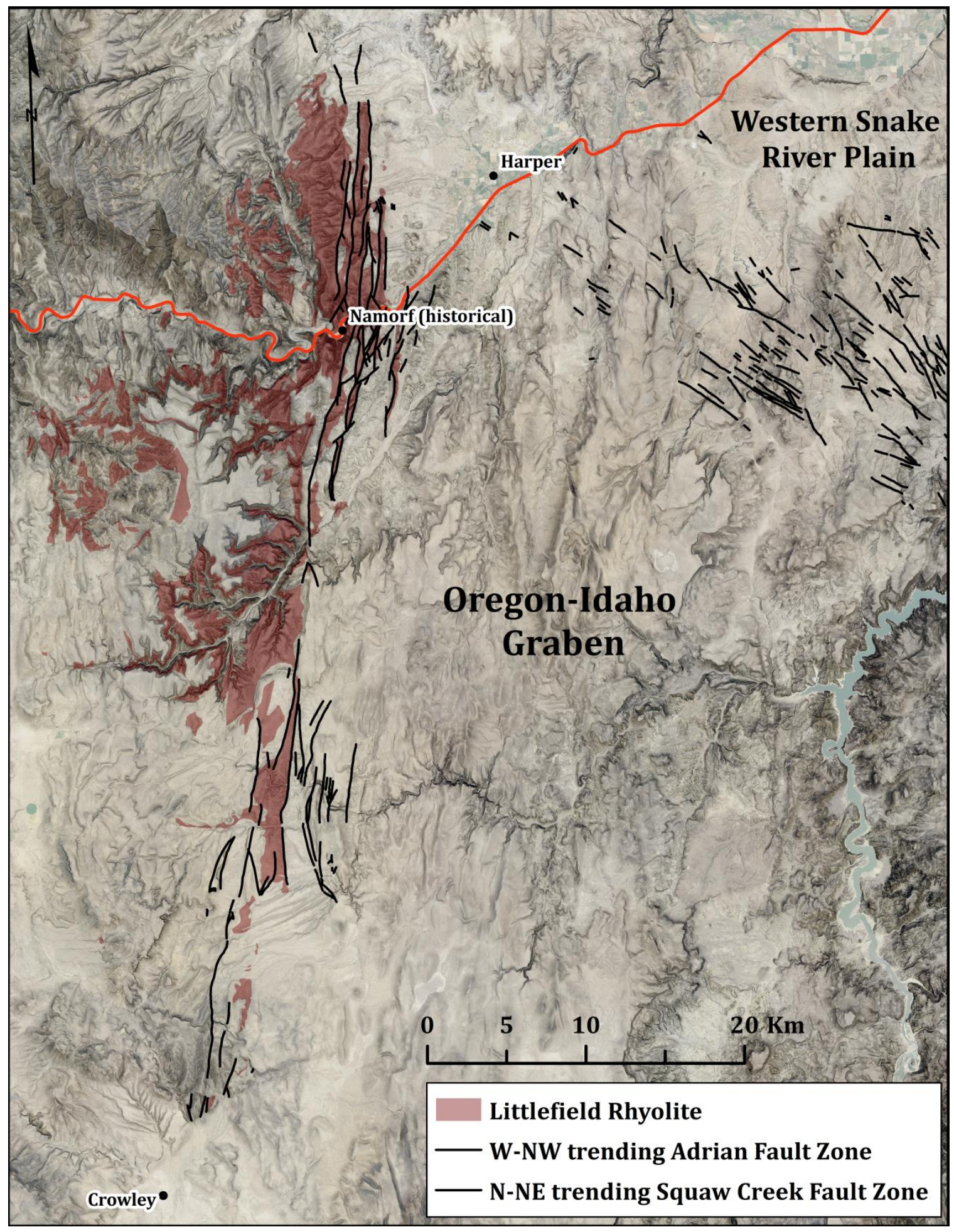

Figure 3: Map shows the approximate alignment of the Littlefield Rhyolite along the N-NE trending Squaw Creek Fault Zone that forms the northwestern margin of the Oregon-Idaho Graben (Cummings et al., 2000). The W-NW trending Adrian Fault Zone forms the northern extent of the graben, separating it from the Western Snake River Plain located to the North. 


\section{Prior Work On The Littlefield Rhyolite}

The Littlefield Rhyolite was first described by Kittleman and co-workers in the early 1960's during 1:125,000 scale geological mapping of the Owyhee region, southeastern Oregon (Kittleman et al., 1965, 1967) (Figure 4).

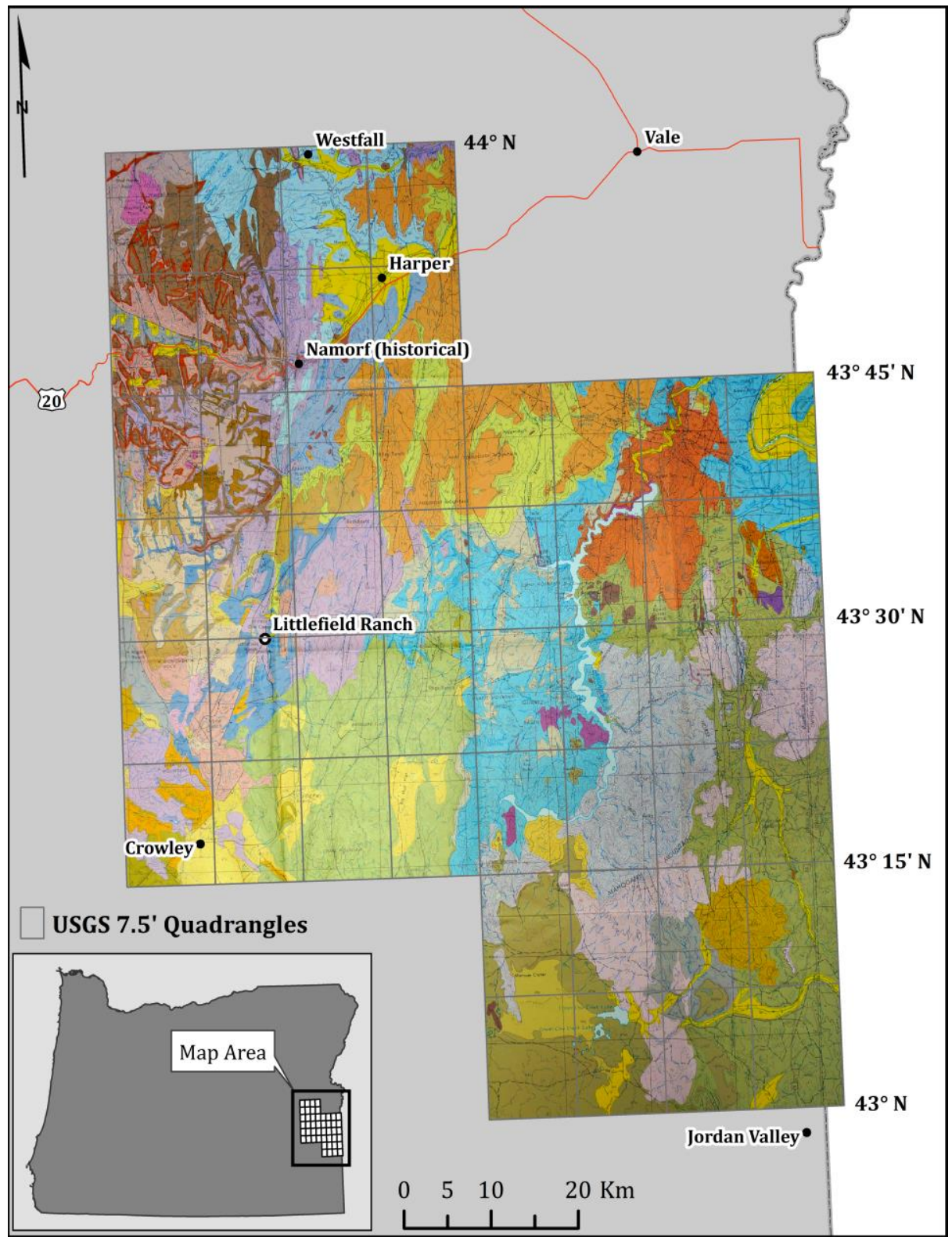

Figure 4: Map shows the extent of the original geological mapping of the Owyhee region compiled by Kittlemen et al. (1967). United States Geological Survey 7.5 minute quadrangle boundaries with labeled lines of latitude have been added for reference. Map datum and projection is NAD83, Oregon Statewide Lambert. 
The Littlefield Rhyolite was named after the Littlefield Ranch (historical), located near the designated type section. The type section of the Littlefield Rhyolite is located at the far southern extent of what is a widely distributed unit, and the early defining descriptions characterizing the unit are clearly based on observations of the southern extents. Here, the Littlefield Rhyolite forms a single, widespread lava flow package that gently dips towards the south. The unit consists of lithoidal rhyolite with a basal vitrophyre that forms a distinct, well-defined lower contact with the underlying unit. Basal breccia is absent. The unit displays pervasive, 1-3 cm spaced, platy-jointing that does not clearly appear to coincide with direction of flow. To see the Littlefield Rhyolite of Kittleman at al. $(1965,1967)$, one must travel south of the Malheur River Gorge.

Incidentally, a number of other units, which are lithologically similar-looking but nevertheless stratigraphically and geochemically distinct, were initially mapped as Littlefield Rhyolite by Kittleman, et al. (1967). These additional units included the rhyolite at Stockade Mountain, rhyolite at Star Mountain, rhyolite of Dry Creek, and upper ferrolatite lava flows of Ferns et al. (1993), the rhyolite of Bully Creek Canyon of Brooks and O'Brien (1992a, 1992b), the lower Littlefield Rhyolite of Lees (1994), and the rhyolite of Cottonwood Mountain of Evans and Binger (1994d) (Figure 5). 


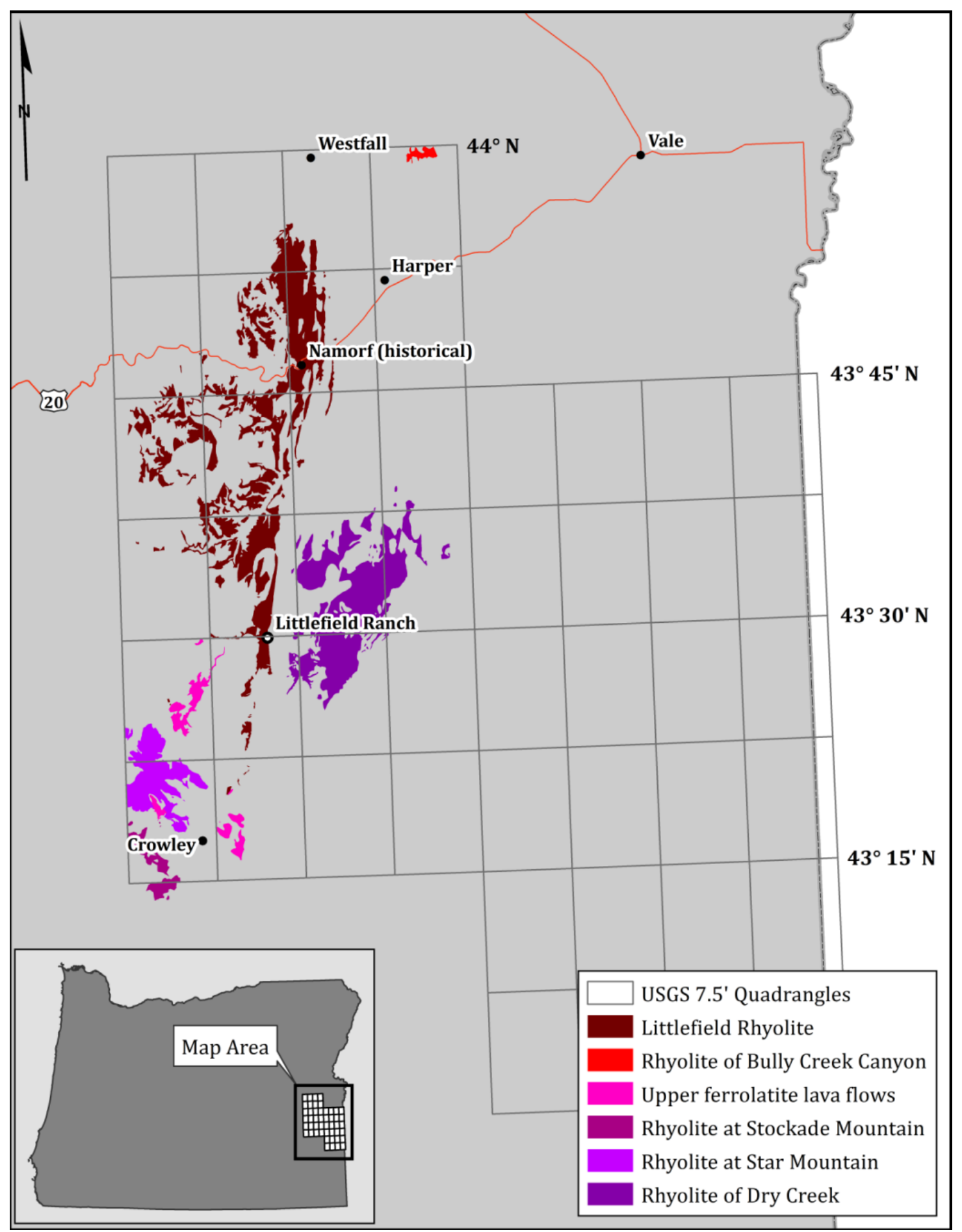

Figure 5: Map shows the distribution of additional geological units that were initially mapped as belonging to the Littlefield Rhyolite by Kittlemen et al. (1967). United States Geological Survey 7.5 minute quadrangle boundaries with labeled lines of latitude have been added for reference. Map datum and projection is NAD83, Oregon Statewide Lambert. Compiled geological mapping GIS data is courtesy of the Oregon Department of Geology and Mineral Industries (Ma et al., 2009). 
Following the pioneering work by Kittleman et al. $(1965,1967)$, a small number of researchers have touched upon various aspects of this extensive rhyolite formation during their investigations. These investigations include more recent 1:24,000 scale geological mapping of select 7.5 minute quadrangles that contain portions of the Littlefield Rhyolite (Brooks and O’Brien, 1992a, 1992b; Evans, 1990, 1994a, 1994b, 1996; Evans and Binger, 1996, 1999a, 1999b, 1999c, 1999d, 1999e; Evans and Keith, 1996; Ferns et al., 1993; Ferns and O’Brien, 1992a, 1992b) (Figure 6), along with studies of stratigraphic and geochemical correlations of Miocene volcanism in Eastern Oregon (Binger, 1997; Camp et al., 2003; Lees, 1994; Hooper et al., 2002; Ferns \& McClaughry, 2013), and a study of the stratigraphic and structural evolution of the Oregon-Idaho graben (Cummings et al., 2000). Each of these subsequent investigations have shed new light on select portions and various characteristics of this extensive rhyolite, while raising further questions concerning its identity, number of eruptive units, age, emplacement processes, and potential relationship to time-correlative Columbia River Basalt Group (CRBG) magmatism.

\section{Identification of the Lower Littlefield Rhyolite}

Kittleman et al. $(1965,1967)$ described the Littlefield Rhyolite as stratigraphically overlying the Hunter Creek Basalt, even though the mapped distribution included lithologically and petrographically similar rhyolite that underlies the Hunter Creek Basalt in some areas (Brooks and O'Brien, 1990). Subsequently, later researchers began to note that the Littlefield Rhyolite of Kittleman et al. (1967) consisted of two distinct units, based on differences in trace element geochemistry (Lees, 1994; 
Hooper el al., 2002; Ferns and O'Brien, 1992a) and relative stratigraphic positions above or below the Hunter Creek Basalt (Brooks and O'Brien, 1990; Cummings et al., 2000). Each researcher has dealt with this discrepancy in different ways, and the underlying rhyolite has been given different names in different areas by different researchers (Figure 6). These names include the 'lower Littlefield Rhyolite' (Lees, 1994), the 'Rhyolite of Bully Creek Canyon' (Brooks and O'Brien, 1990), and the 'Rhyolite of Cottonwood Mountain' (Evans, 1994a, 1994b; Hooper et al., 2002; Cummings et al., 2000). Ferns and O'Brien (1992a), while noting the geochemical differences between two rhyolite lavas exposed along the Malheur River, choose to include the lower unit as part of the Littlefield Rhyolite, in line with Kittleman at al. $(1965,1967)$.

The 'Rhyolite of Cottonwood Mountain' is the name given to extensive rhyolite exposures in the vicinity of Cottonwood Mountain, northwest of Vale, Oregon, (Evans, unpublished mapping, 1995a, 1995b), and has gained acceptance by a number of researchers when referring to the lower rhyolite, based upon similar geochemistry. Nevertheless, there is currently sparse published mapping on the distribution of the rhyolite of Cottonwood Mountain as well as the lower rhyolite, which continues to remain mapped as the Littlefield Rhyolite of Kittleman et al. (1967) in most areas. Additionally, the rhyolite exposures at Cottonwood Mountain remain stratigraphically isolated from units exposed in the south by basin development and the deposition of younger units. 


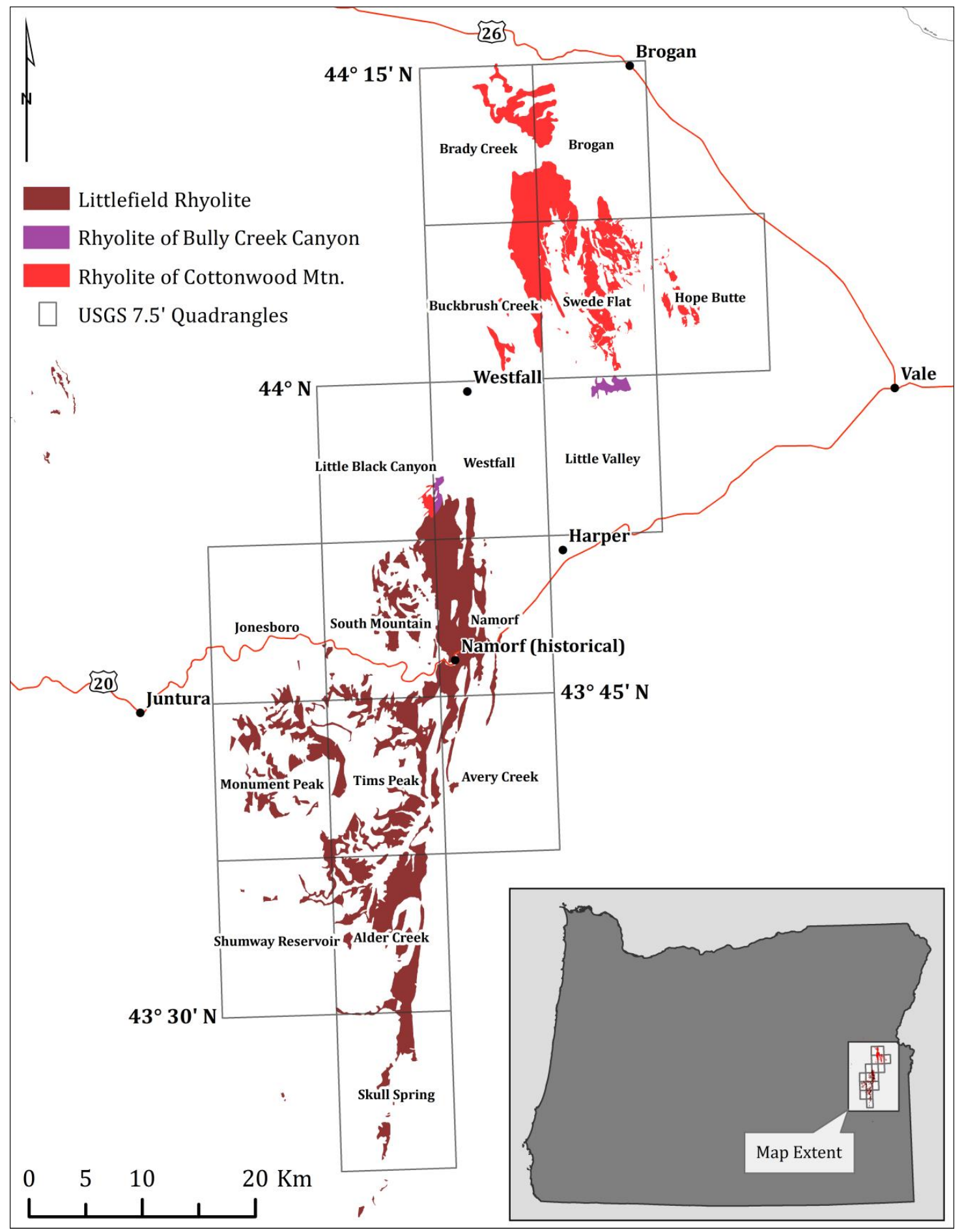

Figure 6: Mapping of select 7.5' quadrangles were performed during the 1990's, when individual workers began to identify and distinguish an additional, underlying rhyolite unit that had been previously mapped as the Littlefield Rhyolite by Kittleman et al. (1967). Unpublished mapping performed north of the 44th parallel (Evans $(1995 \mathrm{a} ; 1995 \mathrm{~b})$ revealed extensive rhyolite exposures around Cottonwood Mountain. Note that all mapping north of the $4^{\text {th }}$ parallel remains currently unpublished. 
Additionally, researchers differ in their stratigraphic descriptions of the Rhyolite of Cottonwood Mountain. Hooper et al. (2002) describes the Rhyolite of Cottonwood Mountain as typically underlying, though sometimes overlying, the Hunter Creek Basalt. In contrast, Cummings et al. (2000) describes the Rhyolite of Cottonwood Mountain as only underlying the Hunter Creek Basalt. What is agreed upon by all authors is that while the lower rhyolite and the upper rhyolite are lithologically and petrographically similar, they are geochemically distinct. The overlying unit contains high $\mathrm{Zr}(>450 \mathrm{ppm})$ and low $\mathrm{TiO}_{2}(\sim 0.4$ wt.\%), whereas the underlying unit has higher $\mathrm{TiO}_{2}$ ( $\sim 0.7$ wt.\%), but lower $\mathrm{Zr}(<300 \mathrm{ppm})$ concentrations (Lees, 1994) (Figure 7).

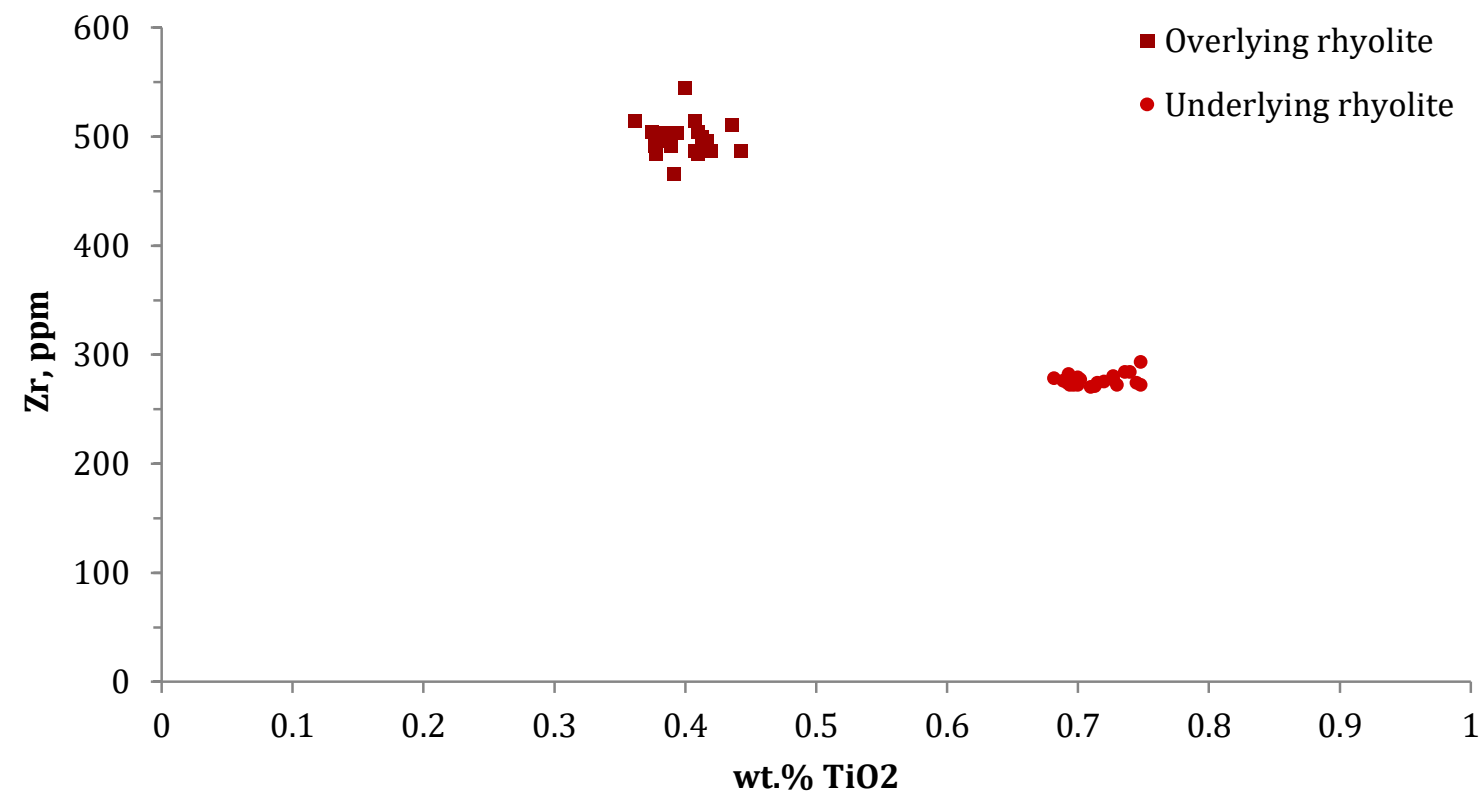

Figure 7: Plot of $\mathrm{Zr}$ (ppm) versus Ti02 (wt.\%) shows distinct geochemical differences between the lithologically and petrographically similar overlying and underlying rhyolite units. The underlying rhyolite unit has been denoted as the Littlefield Rhyolite (Kittleman et al., 1965, 1967), the Lower Littlefield Rhyolite (Lees, 1994), the Rhyolite of Cottonwood Mountain (Hooper, et al., 2004; Cummings, et al., 2000) and the Rhyolite of Bully Creek Canyon (Brooks \& O'Brien, 1990)). The overlying rhyolite unit has been called the Littlefield Rhyolite by all authors. XRF data is from Hooper et al. (2002). 
The continued difficulties in distinguishing the upper and lower rhyolites were likely influenced by the fact that the two units are rarely viewed in sequence, and are separated by Hunter Creek Basalt, which is lithologically, petrographically, and geochemically similar to Birch Creek lavas that are located immediately downsection from the rhyolites. Birch Creek lavas are separated from the lower rhyolite by the Dinner Creek Tuff, which commonly forms an excellent, well-defined stratigraphic marker in areas further to the west of the rhyolites, but becomes relatively thin, incipiently-welded, and porous, leading thus to fewer outcrops in the areas further east where it underlies the lower rhyolite. In these areas, the presence of Dinner Creek Tuff is observed as relatively light-colored float among dominantly dark-colored talus. Thus, in many places, either of these similar looking rhyolites can appear to overlie tholeiitic lavas that can be similarly undistinguishable in the field.

\section{Prior Age Dates for the Littlefield Rhyolite}

Prior efforts by investigators to determine a reliable age for the Littlefield Rhyolite have been unsuccessful (unpublished data of Kittleman et al., 1967, recalculated by Fiebelkorn et al., 1983; Lees, 1994; Hooper et al., 2003; Hess, 2014) (Table 1), likely due, at least in part, to the relatively low concentrations of potassium within feldspar phenocrysts, and likely due to excess Ar captured in melt inclusions in plagioclase. For instance, Hooper et al. (2003) acquired a ${ }^{40} \mathrm{Ar} /{ }^{39} \mathrm{Ar}$ age of $16.6+/-$ 0.1 Ma for the Littlefield Rhyolite. This age was rejected by the authors as being inaccurate based upon stratigraphic relations, as it would suggest that the Littlefield 
Rhyolite was older than the underlying tholeiitic units. Hooper et al. (2003) suggested an age of 15.3 Ma for the Littlefield Rhyolite, which was simply an approximation based upon the average ages of the surrounding stratigraphic units. Age date analyses acquired by other investigators have shown similar results (Fiebelkorn et al., 1983; Lees, 1994; Hess, 2014). Commonly, the calculated age was impossibly older than the true age based on relative stratigraphic position. A few of the prior ages that have been acquired were impossibly young.

Table 1: Prior age dates for Littlefield Rhyolite, rhyolite of Cottonwood Mountain, and rhyolite of Bully Creek Canyon. Littlefield Rhyolite samples of Hooper et al. (2003), Lees (1994), and Hess (2014, are for what we refer to here as the upper Littlefield Rhyolite. Littlefield Rhyolite sample of Kittleman et al. (unpublished) is likely the same, but with uncertainty given the sample location provided. *Unpublished sample of Kittleman recalculated by Fiebelkorn et al. (1983).

\begin{tabular}{|c|c|c|c|c|}
\hline Unit & Method & Age (Ma) & $\operatorname{Error}( \pm 2 \sigma)$ & Source \\
\hline Littlefield Rhyolite & ${ }^{40} \mathrm{Ar} /{ }^{39} \mathrm{Ar}$ & 16.6 & 0.20 & Hooper et al. (2003) \\
\hline Littlefield Rhyolite & ${ }^{40} \mathrm{Ar} /{ }^{39} \mathrm{Ar}$ & 14.7 & 1.92 & Lees (1994) \\
\hline Littlefield Rhyolite & ${ }^{40} \mathrm{Ar} /{ }^{39} \mathrm{Ar}$ & 16.8 & 0.80 & Lees (1994) \\
\hline Littlefield Rhyolite & $\mathrm{K} / \mathrm{Ar}$ & 17.9 & 1.20 & $\begin{array}{l}\text { *Kittleman et al., } \\
\text { unpublished }\end{array}$ \\
\hline Littlefield Rhyolite & ${ }^{40} \mathrm{Ar} /{ }^{39} \mathrm{Ar}$ & 16.75 & 0.90 & Hess (2014) \\
\hline rhyolite of Cottonwood Mtn. & ${ }^{40} \mathrm{Ar} /{ }^{39} \mathrm{Ar}$ & 15.5 & 1.40 & Hooper et al. (2003) \\
\hline rhyolite of Cottonwood Mtn. & ${ }^{40} \mathrm{Ar} /{ }^{39} \mathrm{Ar}$ & 15.7 & 0.40 & Hooper et al. (2003) \\
\hline rhyolite of Cottonwood Mtn. & ${ }^{40} \mathrm{Ar} /{ }^{39} \mathrm{Ar}$ & 14.6 & 2.00 & Hooper et al. (2003) \\
\hline rhyolite of Cottonwood Mtn. & ${ }^{40} \mathrm{Ar} /{ }^{39} \mathrm{Ar}$ & 15.24 & 0.62 & Lees (1994) \\
\hline $\begin{array}{c}\text { rhyolite of Bully Creek } \\
\text { Canyon }\end{array}$ & ${ }^{40} \mathrm{Ar} /{ }^{39} \mathrm{Ar}$ & 17.01 & 0.60 & Hess (2014) \\
\hline
\end{tabular}




\section{CHAPTER 3: METHODS}

Fieldwork consisted of distinguishing stratigraphic units and collecting representative rock samples from each unit. Care was taken to avoid samples that had undergone alteration, as the region was susceptible to hydrothermal processes during times of volcanic subsidence (Cummings et al., 2000). Preliminary 1:10,000 scale geological mapping was performed, to document the diverse stratigraphy exposed in the areas surrounding Namorf, at the eastern extent of the Malheur River Gorge.

A total of 57 samples collected in the field, of upper Littlefield Rhyolite and lower Littlefield Rhyolite, were analyzed at Portland State University using a BRUKER Tracer IV-SD portable XRF spectrometer (pXRF), which allowed for rapid and widespread identification of rhyolite flow units by exploiting distinct differences in $\mathrm{Zr}$ and $\mathrm{Nb}$ concentrations (Figure 8). Extensive use of pXRF analyses allowed testing assigned identity of individual rhyolite outcroppings observed in the field. Rhyolite samples were cut into billets and one surface polished to $30 \mu \mathrm{m}$, and then the groundmass of each sample was targeted for pXRF analysis. Zircon is not observed in either of the Littlefield Rhyolite units and zirconium is presumably equally distributed throughout the glassy groundmass. Vesicular samples often produced lower than expected $\mathrm{Zr}$ values (20-40 ppm). See the appendix for a map of pXRF sample locations and detailed results of pXRF analyses. 


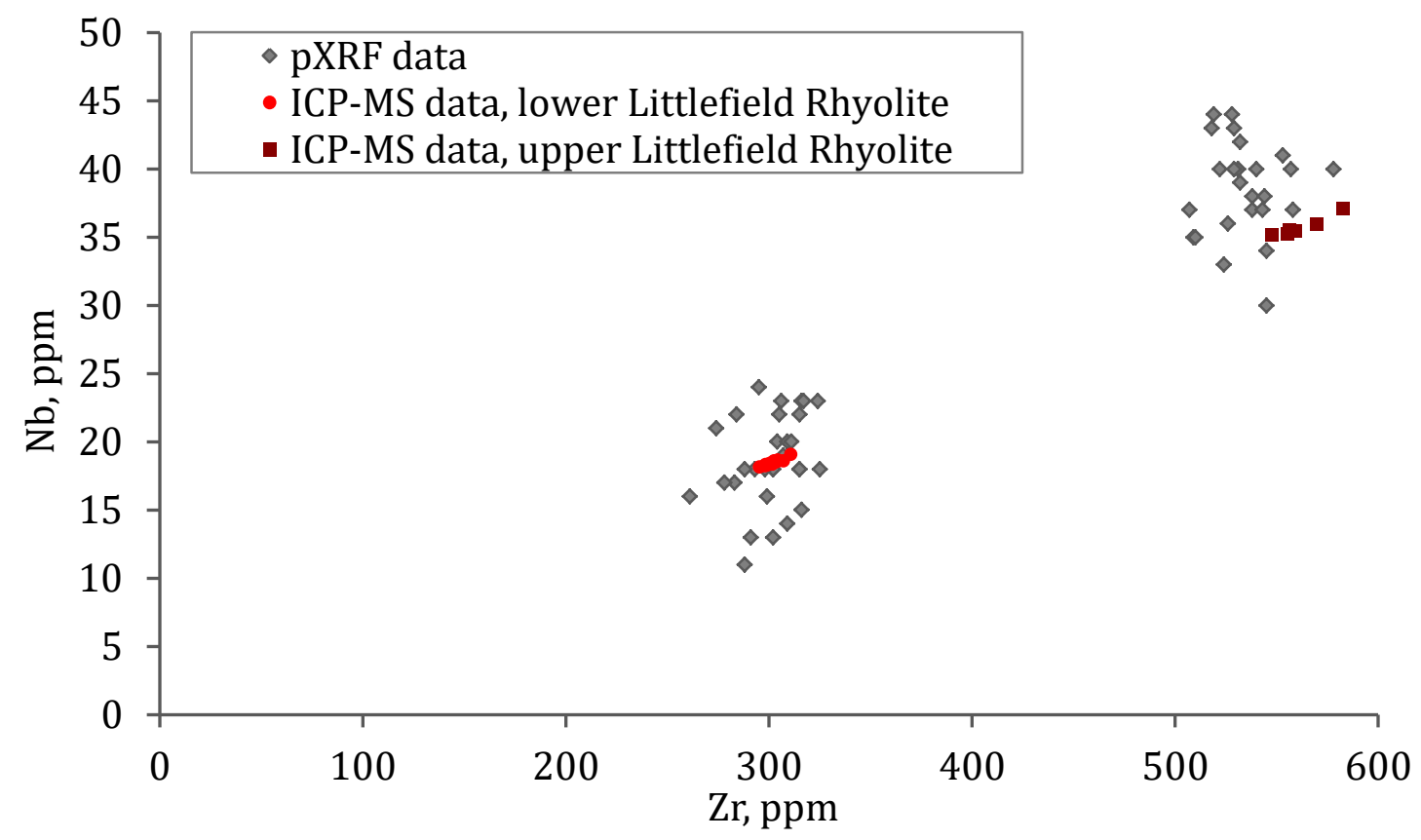

Figure 8: Plot shows $\mathrm{Nb}$ (ppm) versus $\mathrm{Zr}$ (ppm) concentrations for 57 combined samples of Upper Littlefield Rhyolite and Lower Upper Littlefield Rhyolite obtained from pXRF analysis (shown in grey), and compared to ICP-MS analysis of a subset of these samples (upper Littlefield Rhyolite shown in burgundy; lower Littlefield Rhyolite shown in red).

Petrographic thin sections were prepared from a subset of the collected samples and analyzed using a petrographic microscope. Mineral occurrence and modal abundance, textures of the groundmass, and other distinguishing features have been documented. Petrographic thin-sections were polished to $1 \mu \mathrm{m}$ for Electron Microprobe (EMP) and Scanning Electron Microscope (SEM) analysis.

Major element compositions of feldspar, pyroxene, and titanomagnetite phenocrysts, glass (groundmass), and apatite microlites for two samples of lower Littlefield Rhyolite were acquired using a Zeiss Sigma VP Scanning Electron Microscope (SEM), at Portland State University. Additional exploratory microanalytical work consisted of acquiring qualitative imagery of phenocryst phases and groundmass textures using both 4- and 5-segment backscatter electron (BSE) 
detectors and cathodoluminescence (CL) detector. Precise major element compositions of feldspar, pyroxene, and titanium magnetite phenocrysts of rhyolite samples were acquired with the Oregon State University Cameca SX100 Electron Probe Micro-Analyzer (EPMA), operated remotely from Portland State University. Known mineral standards were used for calibration.

Major and trace element compositions of select samples collected in the field were acquired for better characterization and comparison of different units identified in the stratigraphic transects. Major and trace element compositions of 42 bulk samples were determined by X-ray fluorescence (XRF) and by inductively coupled plasma-mass spectrometry (ICP-MS) by the Washington State University GeoAnalytical Laboratory. All sample preparation was performed by me at the Washington State University GeoAnalytical Laboratory.

Single-crystal analyses of upper and lower Littlefield Rhyolite samples were performed at the New Mexico Geochronology Research Laboratory at New Mexico Tech, Socorro, under the supervision of William McIntosh. Hydrogen fluoridecleaned feldspar separates from rhyolite samples and Fish Canyon Tuff sanidine monitors were irradiated at the Denver United States Geological Survey TRIGA reactor. Individual feldspar grains were fused by $\mathrm{CO}_{2}$ laser and analyzed using a Thermo Argus VI mass spectrometer. Pychron software (Ross, 2014) was used to control analyses and reduce data. All resulting age calculations are determined relative to a Fish Canyon Tuff age of 28.201 Ma (Kuiper et al., 2008). 


\section{CHAPTER 4: RESULTS}

\section{Overview of Field Work}

Stratigraphic transects were performed at three areas of interest distributed within the mapped areal extent of the Littlefield Rhyolite (Figure 9).

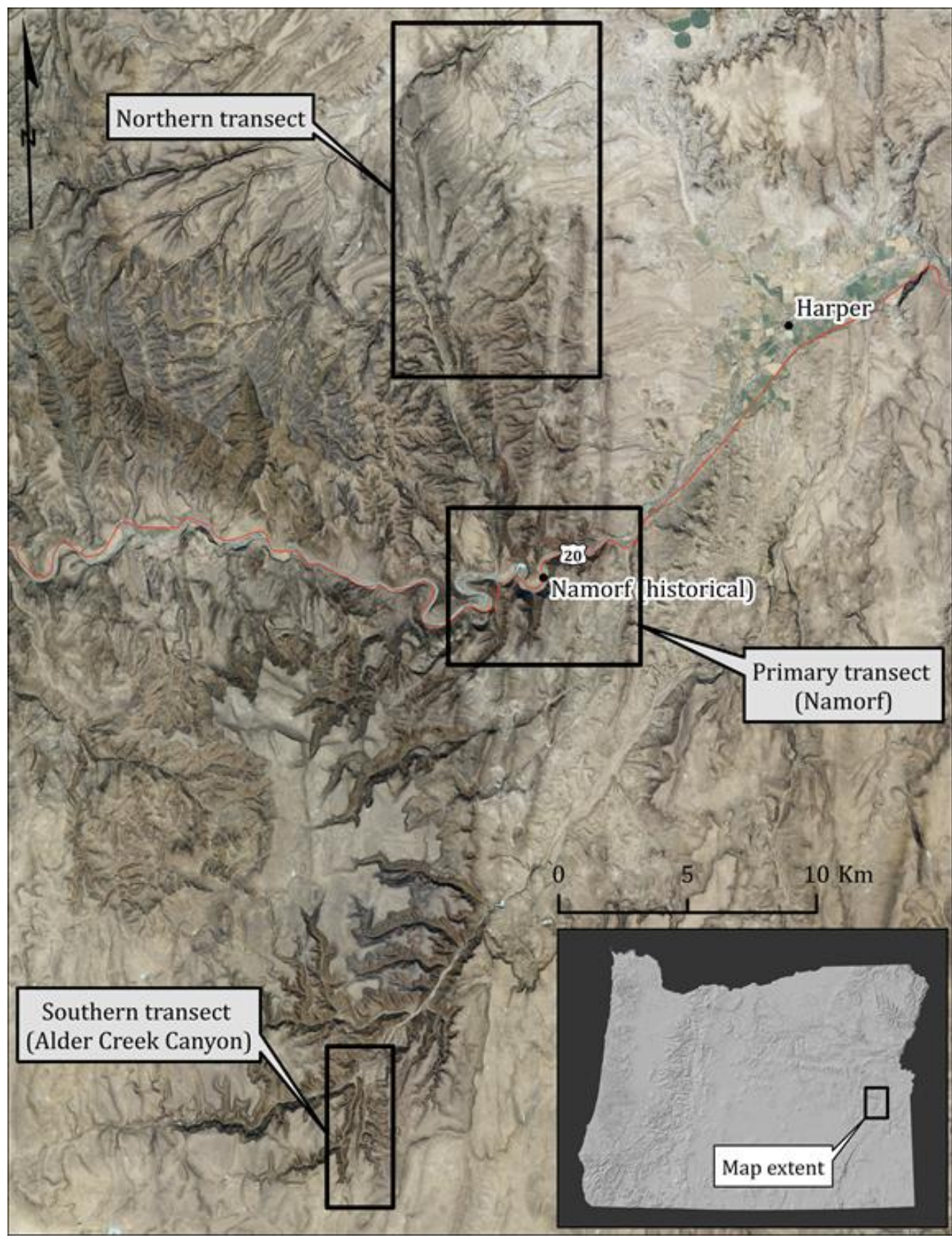

Figure 9: Overview map showing the three areas of interest where transects were performed. 
The primary transect was performed within the Malheur River Gorge, where MidMiocene volcanic stratigraphy is spectacularly exposed (Figure 10). Additional transects were performed towards the northern and southern mapped extents of the Littlefield Rhyolite. The northern transects were performed across a relatively broad geographical area north of the Malheur River Gorge and southwest of Westfall. The southern transect was performed in Alder Creek Canyon. Fieldwork identifications of the lithologically similar, but geochemically distinct, rhyolite flow units were continuously supported by analyses of $\mathrm{Zr}$ and $\mathrm{Nb}$ compositions determined by a Bruker Tracer-IV portable X-ray fluorescence (pXRF) spectrometer at Portland State University. Extensive use of a pXRF allowed the identity of all sampled outcrops to be determined after each session of fieldwork, which in turn provided constant feedback of field observations, improving the understanding of the stratigraphy and distribution of these two units.

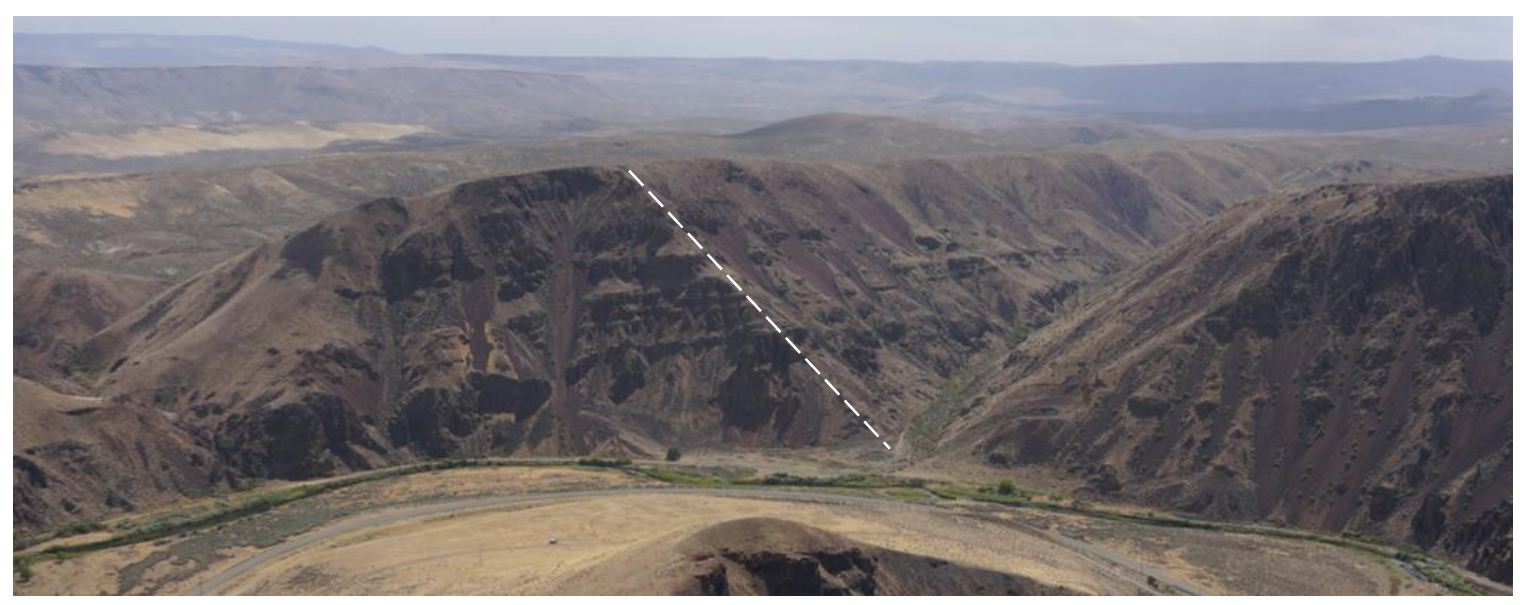

Figure 10: The dashed line highlights the primary transect that was performed at Namorf, within the eastern extent Malheur River Gorge. The $\sim 280 \mathrm{~m}$ thick series of stratigraphic units exposed here were initially mapped as Littlefield Rhyolite by Kittleman et al. (1967), and later by Ferns and O'Brien (1992a). Photo location coordinates are $440150 \mathrm{mE}, 4848741 \mathrm{mN}$. Projection and datum are UTM 11N, NAD83. Center of photograph is facing South-Southeast. 


\section{Stratigraphy of Transects}

\section{Primary Transect at Namorf within the Malheur River Gorge}

The primary stratigraphic transect was performed at Namorf, a historic locality once associated with now decommissioned rail lines within the eastern extent of the Malheur River Gorge. The stratigraphic transect was performed along the south side of the Malheur River where the stratigraphy is spectacularly exposed (Figure 11).

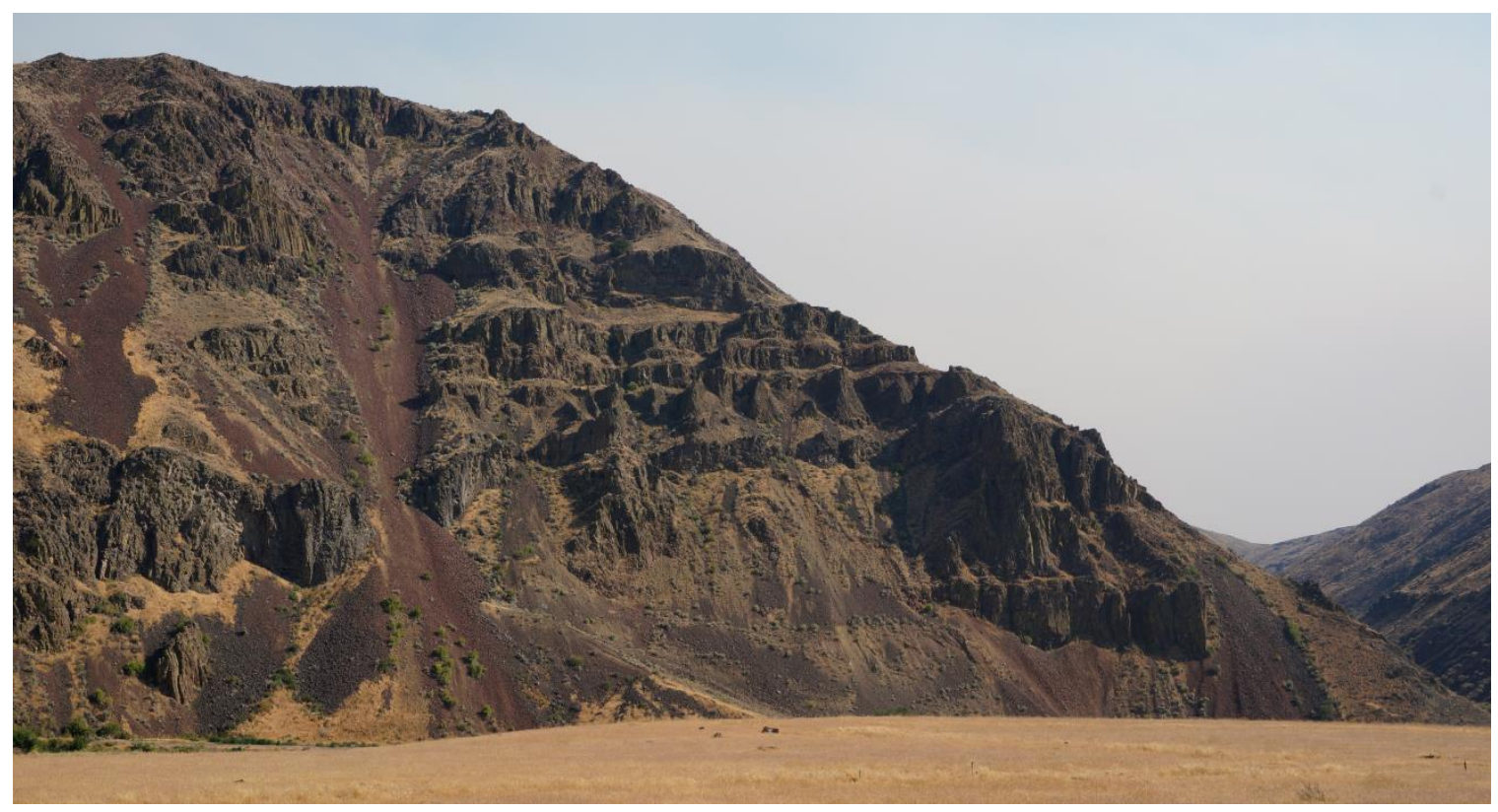

Figure 11: Image shows the $\sim 280 \mathrm{~m}$ thick exposures of interest for the primary transect performed at Namorf, within the eastern extent of the Malheur River Gorge. The stratigraphic sequence viewed here is mapped as Littlefield Rhyolite (Kittleman et al., 1967; Ferns and O’Brien, 1992). Image is taken looking south from a point bar obscuring view of the Malheur River.

The primary transect site is unique; the full bimodal suite of Mid-Miocene units are observable in sequence, units are relatively well-exposed, and uncommonly wellpreserved outcrop of Hunter Creek Basalt (tholeiitic basaltic andesite) can be observed. 
Prior workers mapped the entire stratigraphic sequence observed at Namorf as consisting of multiple Littlefield Rhyolite lava flows (Kittlemen et al., 1965; Ferns \& O'Brien, 1992), with later workers noting that the lowermost and uppermost observed flows appeared to have distinct geochemistry (Ferns \& O'Brien, 1992; Lees, 1994). The primary transect revealed a diversity of units not documented by prior workers (Figure 12).

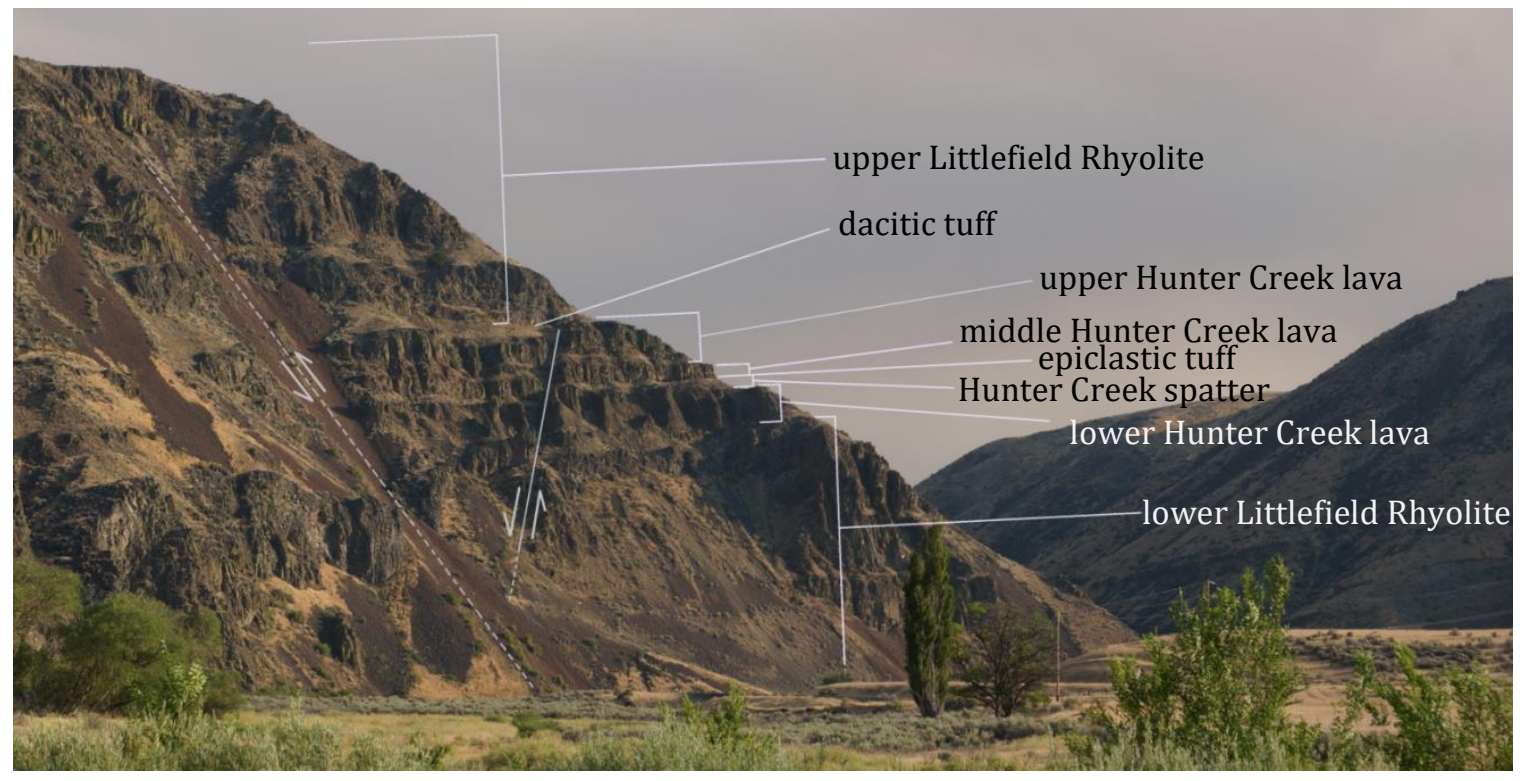

Figure 12: N-NW facing exposures along the Malheur River with 280 meters of steep relief. The transect revealed a variety of additional units sandwiched between two extensive rhyolite lavas.

The basalt of Malheur Gorge is the lowest stratigraphic sequence of units exposed in the eastern area of the Malheur River Gorge, where is it overlain by the Dinner Creek Tuff, followed by the lower Littlefield Rhyolite. The glassy, microbrecciated base of the lower rhyolite flow is observed in a localized stratigraphic section, which has been isolated by normal faulting and truncated by erosion (Figure 13). 


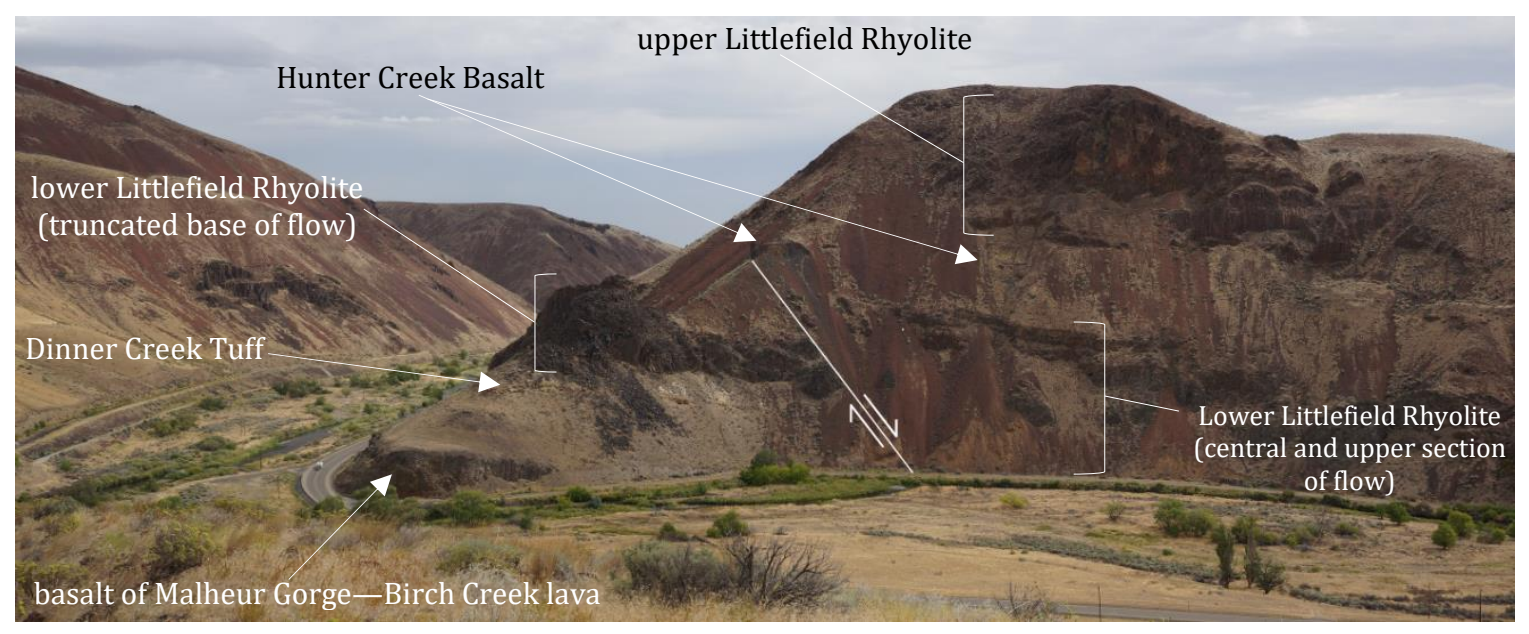

Figure 13: Photograph showing the location where the base of the lower Littlefield Rhyolite is exposed.

The base and upper contact of the lower Littlefield Rhyolite can be observed at Namorf, but exposures of each are separated by normal faulting. The complete flow section cannot be viewed in sequence, and the overall unit thickness here cannot be measured. Typically, differing proportions of the central and upper flow sections of the lower Littlefield Rhyolite are observed, where it forms the lowest exposed stratigraphic unit in this area. These exposed upper flow sections of the Lower Littlefield Rhyolite are up to $120 \mathrm{~m}$ thick. The uppermost extent of the flow is vesiculated and commonly becomes micro-brecciated approaching the upper contact, and reveals a surprising lack of weathering. The preservation of upper flow morphology suggests that the Lower Littlefield Rhyolite was overlain by the Hunter Creek Basalt relatively soon after emplacement.

The Lower Littlefield Rhyolite is overlain by a $\sim 45 \mathrm{~m}$ thick sequence of four tholeiitic units; all of which are geochemically equivalent to Hunter Creek Basalt. This local occurrence of a stack of multiple Hunter Creek lava flows appears to be 
longitudinally confined to a $\sim 2 \mathrm{~km}$ wide section along the south side of the Malheur River at Namorf. Commonly, only a single Hunter Creek lava flow is observed in other areas. On the north side of the Malheur River at Namorf, only a single Hunter Creek lava flow is observed, which is overlain by a relatively thicker deposit of Hunter Creek agglutinated spatter. The spatter deposit is up to $30 \mathrm{~m}$ thick on the north side of the Malheur River (Figure 14), and thins to $<2 \mathrm{~m}$ over a distance of $\sim 800 \mathrm{~m}$, as it is observed along the transect (Figure 16). Approximately $2 \mathrm{~km}$ east from Namorf, only a single Hunter Creek lava flow is observed separating the upper and lower rhyolite flows.

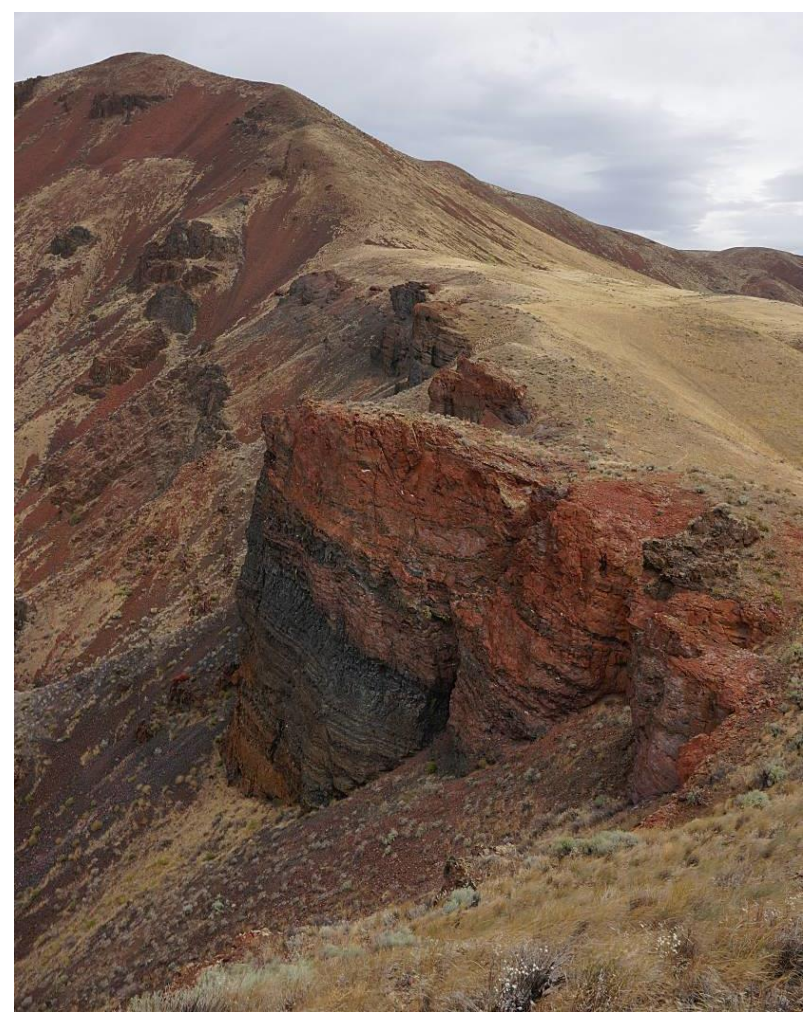

Figure 14: The image above shows a depositional layered agglutinated pyroclastic deposit, which thins rapidly to $<2 \mathrm{~m}$ in exposures located on the opposite side of the river. The unit is composed of agglutinated basaltic andesite, and is compositionally similar to Hunter Creek Basalt. In this case, the source of this particular deposit would have likely been a vent located somewhere to the left of the image. Epiclastic tuff talus overlies the unit in scattered areas. 
Continuing further upsection along the primary transect at Namorf, the Hunter Creek agglutinated spatter deposit is overlain by a thin $(<0.5 \mathrm{~m})$, light-colored, moderately-lithified, epiclastic tuff (Figure 15; Figure 16), followed by two additional Hunter Creek lava flows.

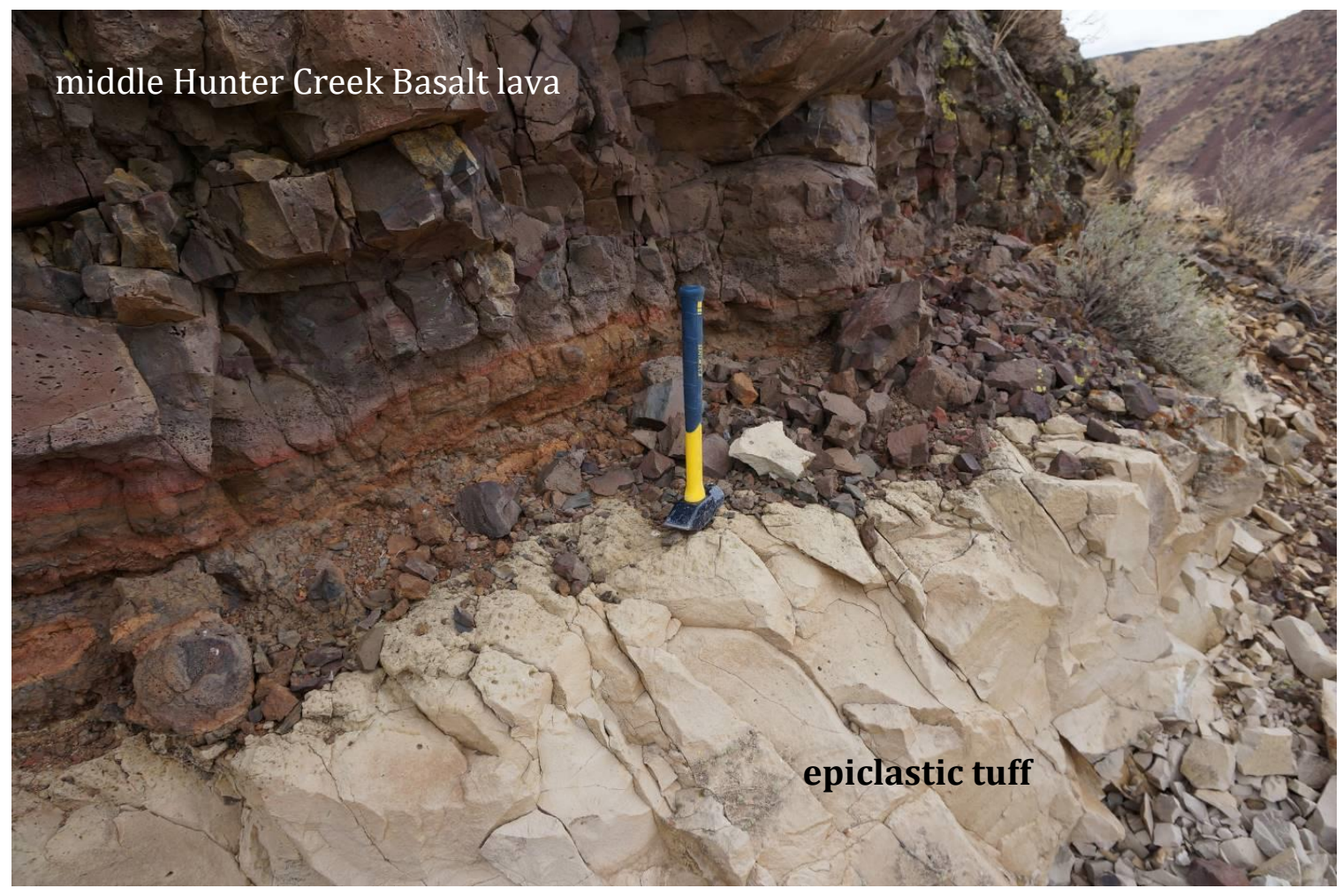

Figure 15: Light-colored epiclastic tuff as observed along the primary transect. The base of the overlying unit shown here is the middle Hunter Creek Basalt lava flow.

The lowest Hunter Creek lava is $\sim 15 \mathrm{~m}$ thick, and is overlain by a $\sim 2 \mathrm{~m}$ thick Hunter Creek agglutinated pyroclastic deposit. The pyroclastic unit is then overlain by a $<0.5 \mathrm{~m}$ thick, moderately lithified, epiclastic tuff, which is then directly overlain by two additional Hunter Creek lavas, herein referred to as the middle and the upper Hunter Creek Basalt lava flows. 


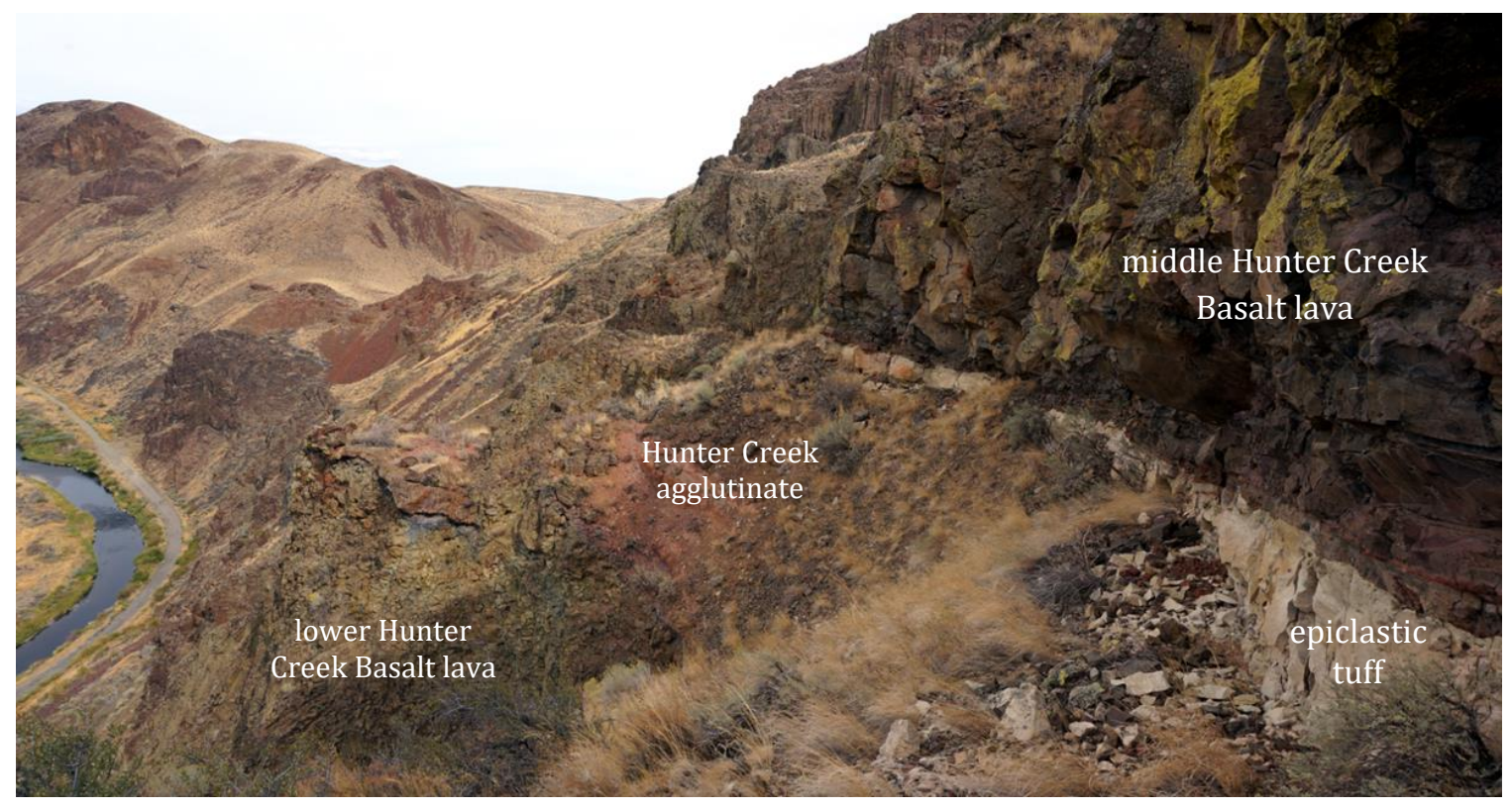

Figure 16: Photograph shows the epiclastic tuff sandwiched between Hunter Creek Basalt units. The Hunter Creek agglutinate is relatively thin in the transect $(\sim 1.5 \mathrm{~m})$.

The $\sim 17 \mathrm{~m}$ thick, upper Hunter Creek lava flow was emplaced directly on top of the $\sim 10 \mathrm{~m}$ thick, middle Hunter Creek flow, as evidenced by a baked-zone at the top of the middle flow (Figure 17). 


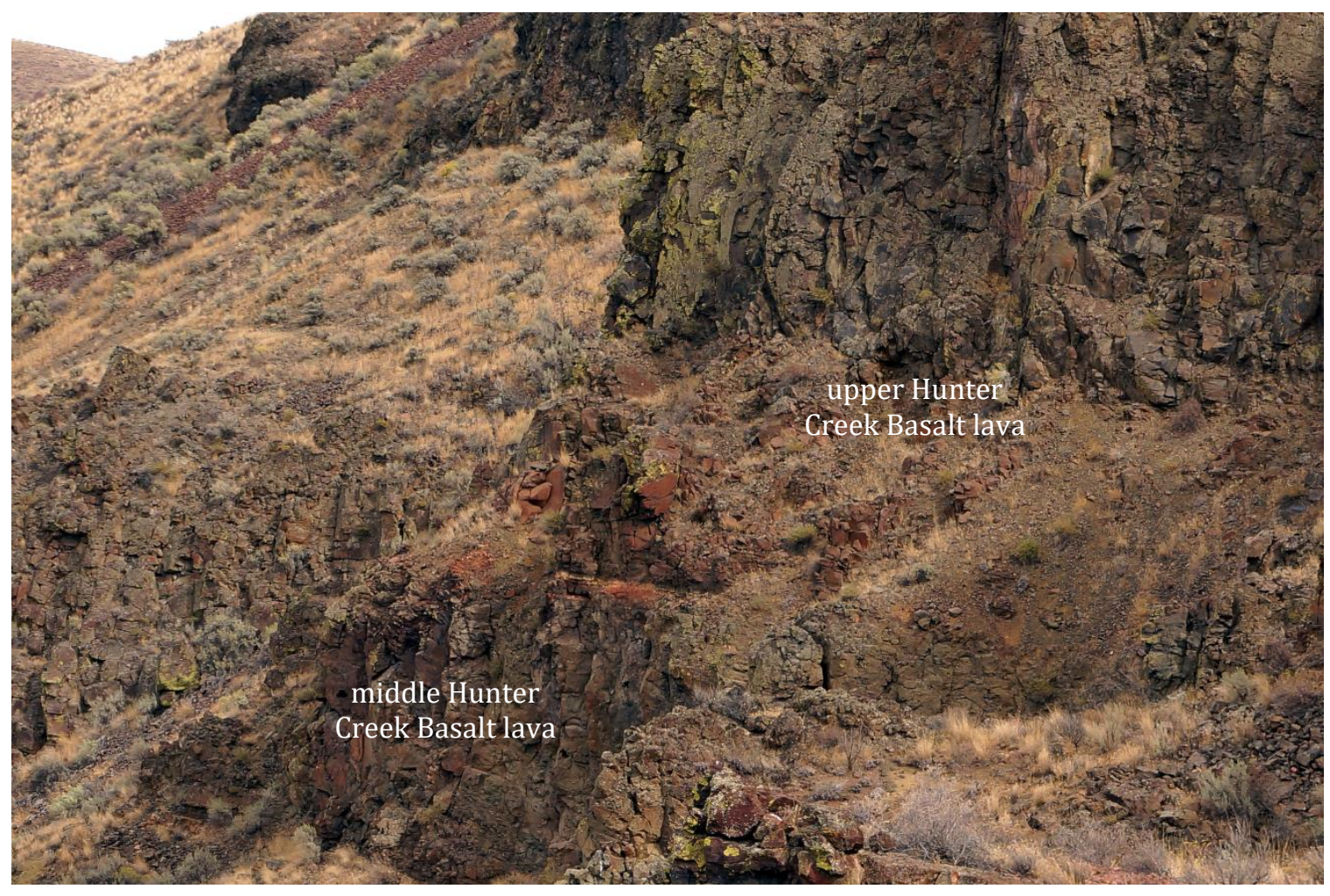

Figure 17: Image shows the middle and the upper Hunter Creek Basalt lavas, including a thin baked-zone along the top of the middle lava flow. Basal breccia of the upper Littlefield Rhyolite is visible in the distance.

Continuing upsection, the package of Hunter Creek units is overlain by $\sim 2 \mathrm{~m}$ of surge deposits--consisting of layered, compacted sand-sized sediment embedded with scattered, angular, cobble- and boulder-sized fragments--followed by a thin lens of a moderately-welded tuff that directly underlies basal autobreccia of the upper Littlefield Rhyolite (Figure 18). 


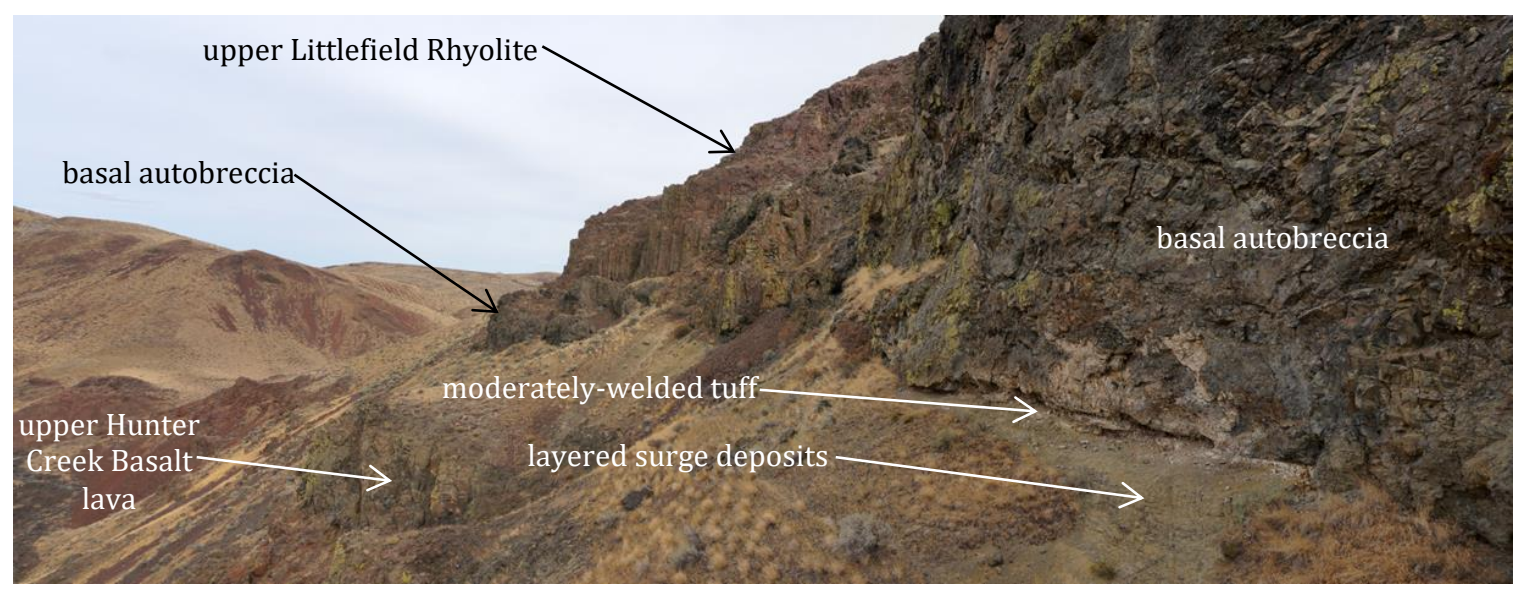

Figure 18: Images shows the exposed base of the upper Littlefield Rhyolite. A thin, moderately-welded tuff overlies surge deposits, and underlies basal breccia of the upper Littlefield Rhyolite. One of the age dates for the upper rhyolite was acquired using a glassy sample of rhyolite breccia from this location.

The upper Littlefield Rhyolite is the youngest stratigraphic unit along the transect, displaying alternating thicknesses of basal autobreccia, capped by dense, glassy, columnar-jointed and lithoidal, platey-jointed rhyolite.

Work on the primary transect revealed that the stratigraphy at Namorf was significantly more diverse than anticipated based on prior geological mapping, and numerous additional transects were performed at Namorf in support of efforts to create a geological map--see appendix.

\section{Evidence of Past Hydrothermal Activity Observed at Namorf}

A number of silicified north-trending faults can be observed within the upper Littlefield Rhyolite at Namorf (Figure 19; Figure 20). Being more resilient to weathering, these silicified, fault-brecciated outcrops within the upper Littlefield Rhyolite can be traced, with some interruptions, for kilometers. 


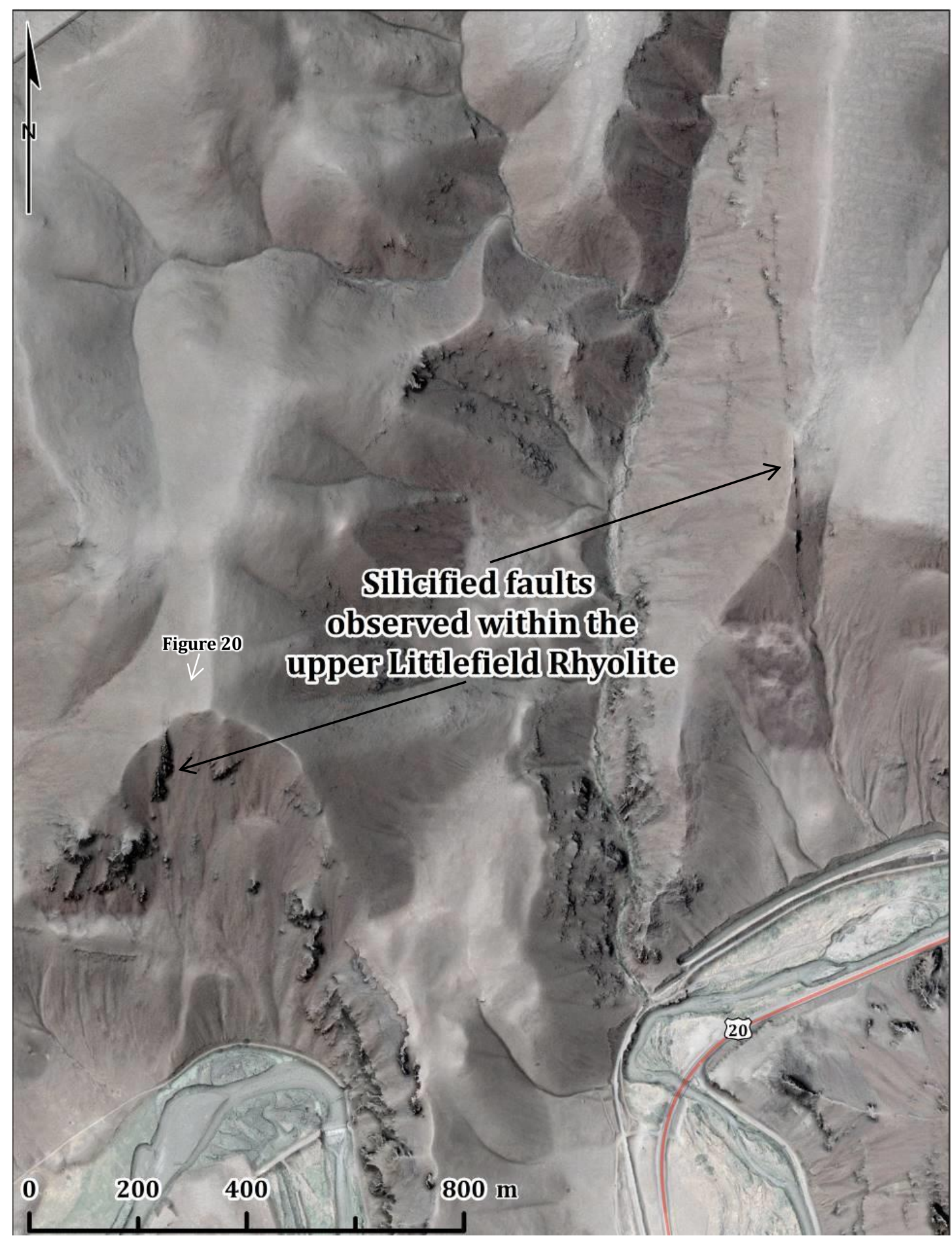

Figure 19: Map showing the north side of the Malheur River at Namorf. Silicified, faultbrecciated outcrops of upper Littlefield Rhyolite form linear, relatively thin and tall features that rise out of the talus dominated slopes and can be traced for kilometers. Map is comprised of a bare-earth lidar derivative overlain with NAIP orthoimagery. Map projection and datum is Oregon Statewide Lambert, NAD 83 HARN. Lidar data is courtesy of the Oregon Lidar Consortium. 


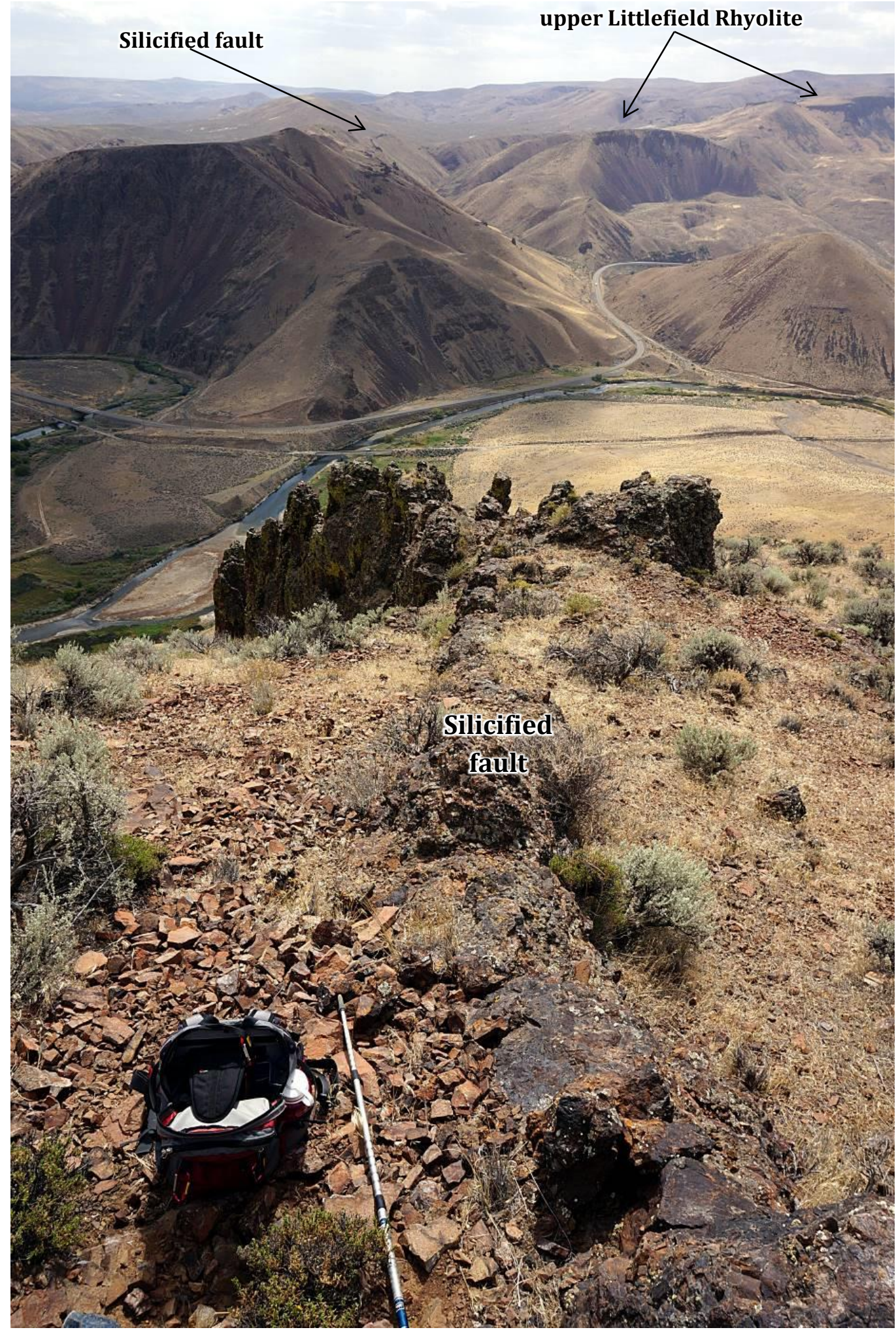

Figure 20: Photo shows proximal and distal silicified fault outcroppings observed in the upper Littlefield Rhyolite. Direction of photo is to the south-southwest. 


\section{Mafic and Silicic Vents Observed within the Malheur River Gorge}

A rhyolite dike can be observed along a steeply-dipping, N-NW striking normal fault within basalt of Malheur Gorge stratigraphy at a US HWY 20 roadcut located to the east of Namorf (Evans, 1990; Ferns and McClaughry, 2013). Geochemistry and ${ }^{40} \mathrm{Ar} /{ }^{39} \mathrm{Ar}$ age dating of the rhyolite dike show this is a lower Littlefield Rhyolite vent In addition, the thickest exposure of glassy, Hunter Creek agglutinated spatter overlies the lower Littlefield Rhyolite on the north side of the Malheur River, suggesting that Hunter Creek magmas erupted here at near liquidus temperatures. The angle of graded, depositional layering, and changes in unit thickness throughout the exposures at Namorf, suggest a vent location in close proximity to the northtrending fault structure associated with the lower Littlefield Rhyolite vent. Both venting sites (Figure 21) appear to be approximately aligned with the north striking Hog Creek fault zone. 


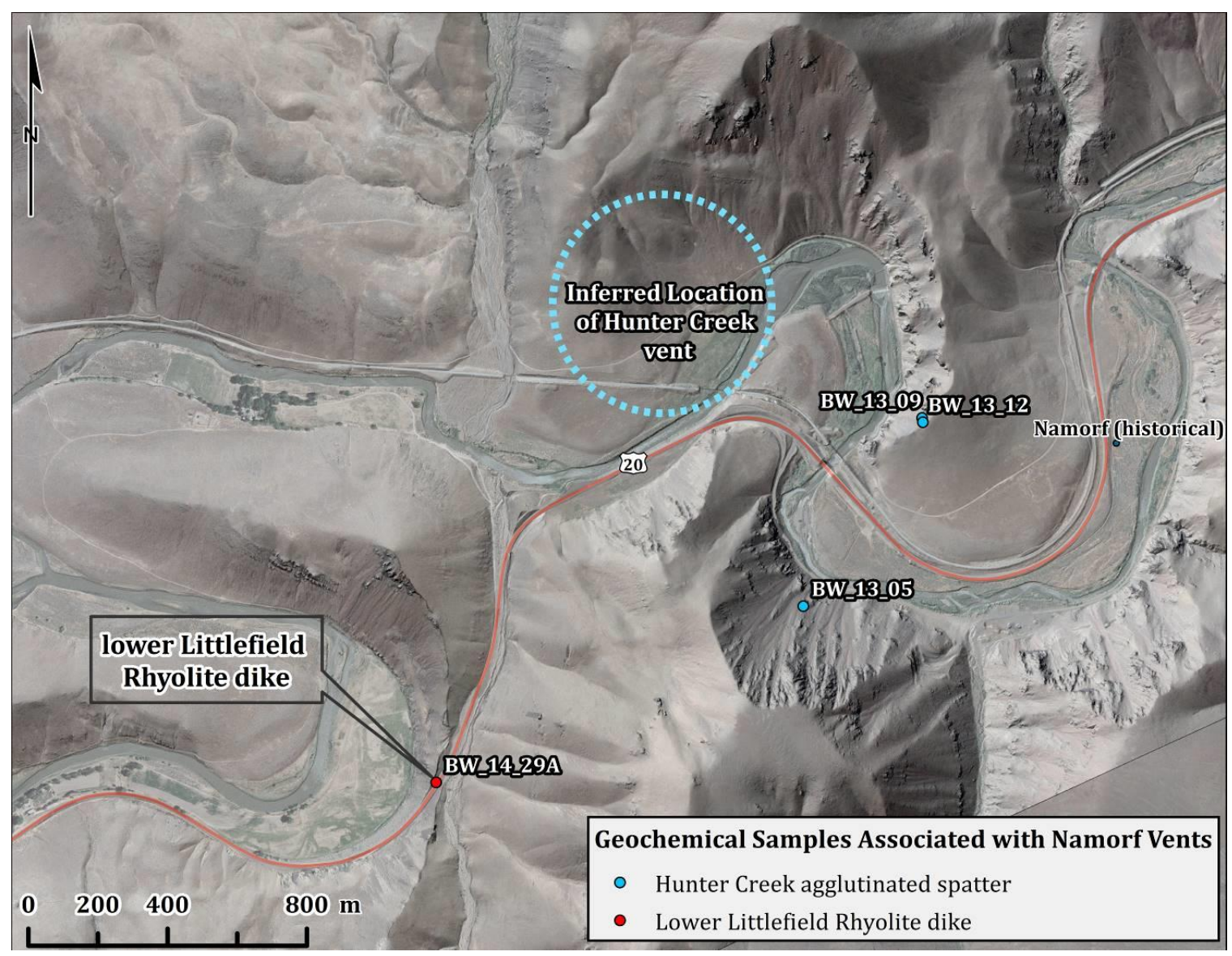

Figure 21: Map shows Hunter Creek Basalt and lower Littlefield Rhyolite vents within the Malheur River Gorge. Hunter Creek vent location is inferred based upon pyroclastic bedding and changes in unit thickness with distance. Vents are roughly aligned along the north striking Hog Creek Fault Zone. Map projection and datum is Oregon Statewide Lambert, NAD 83 HARN. Lidar data is courtesy of the Oregon Lidar Consortium. 


\section{Northern Stratigraphic Transects}

Heading northward and outside of the Malheur River Gorge, the stratigraphy is segmented by a number of north-south striking faults that form sets of $\sim 4-6^{0}$ east dipping, rotated blocks, which commonly have been eroded to form steep, rounded, talus-dominated hills (Figure 22).

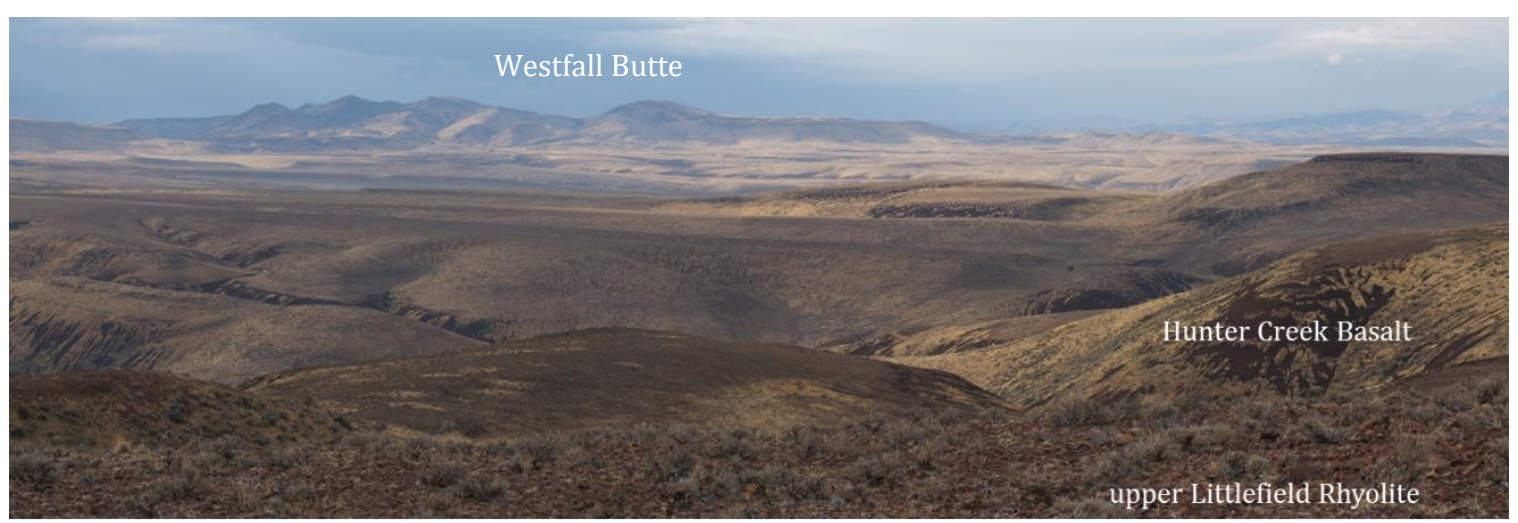

Figure 22: Image taken from the top of Hog Creek Ridge, looking west towards Westfall Butte.

In the furthest northern extent of the upper Littlefield Rhyolite, east to northeast striking normal faulting led to the exposure and subsequent erosion of the underlying Hunter Creek Basalt (Figure 23). The uppermost flow section of the lower Littlefield Rhyolite is exposed here as well, forming surficial outcrops within the primary drainages and other areas of relatively lower relief where erosion of the overlying Hunter Creek Basalt has been relatively more pronounced (Figure 24). 


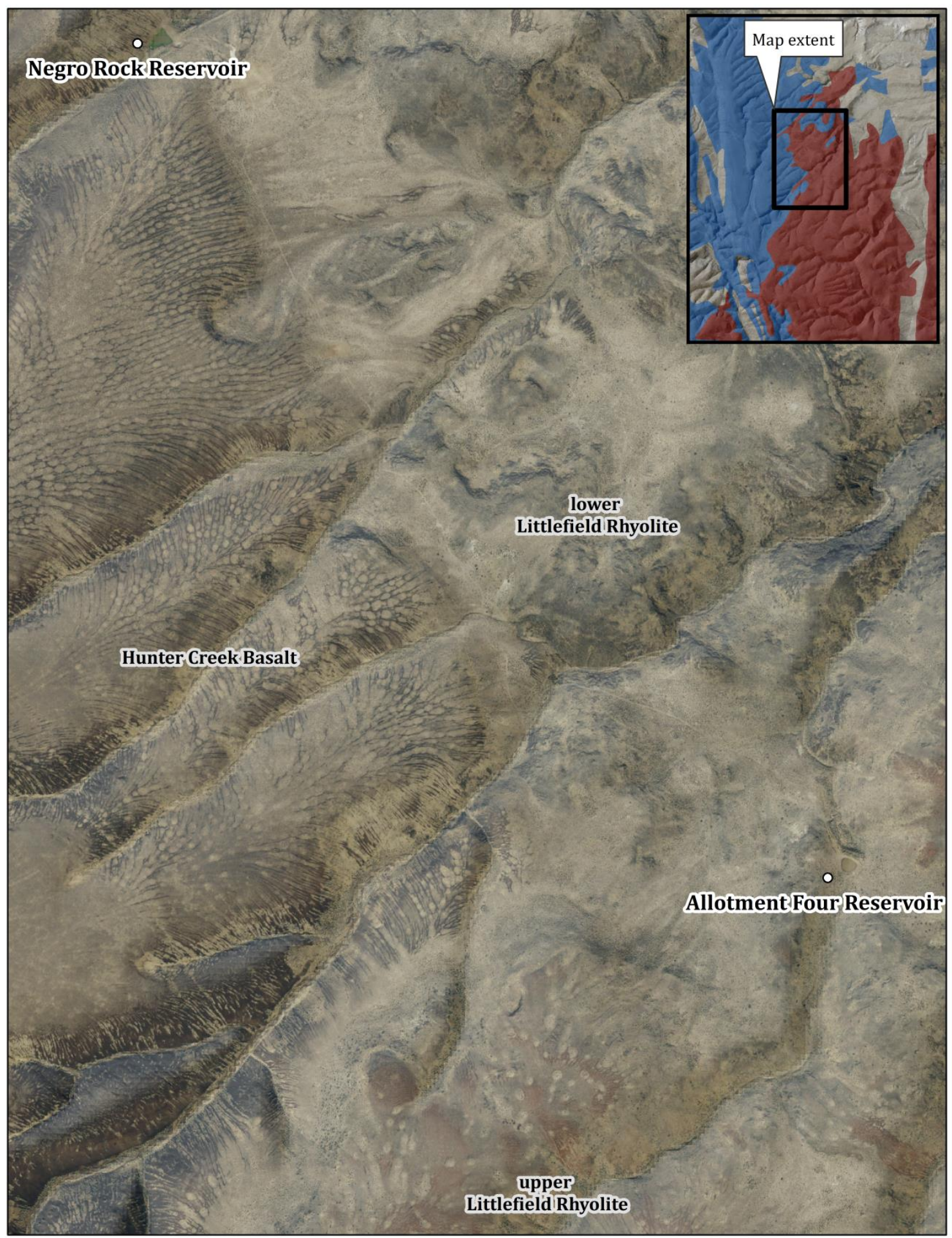

Figure 23: Orthoimagery showing exposures of the lower Littlefield Rhyolite. Relative uplift on the north side of the fault has placed the Hunter Creek Basalt topographically adjacent to the upper Littlefield Rhyolite. The lower Littlefield Rhyolite has been exposed in areas where erosion of the overlying Hunter Creek Basalt has been relatively more pronounced. 


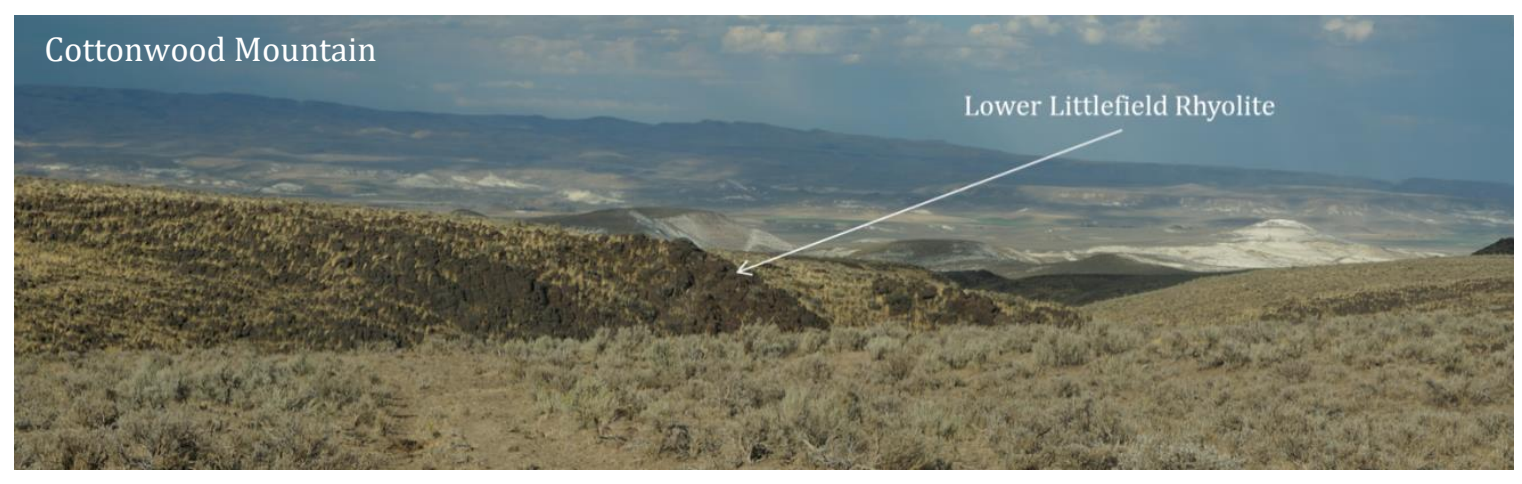

Figure 24: Image taken near Negro Rock Reservoir, looking E-NE. Exposures of the uppermost flow section (vitrophyre) of lower Littlefield Rhyolite appear in drainages and other areas of increased erosion of the overlying Hunter Creek Basalt.

\section{Southern Stratigraphic Transect in Alder Creek Canyon}

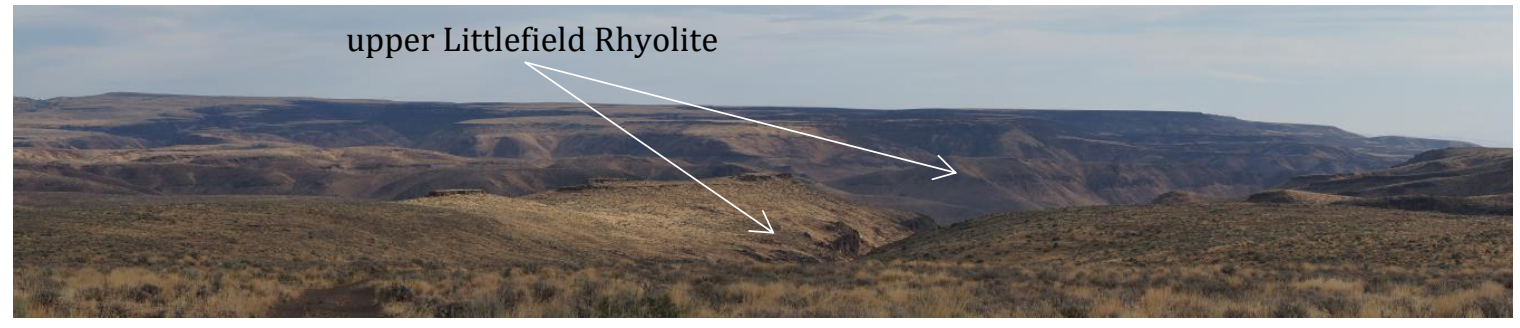

Figure 25: View looking north at the start of the Alder Creek Canyon transect, heading downslope into Alder Creek Canyon. The upper Littlefield Rhyolite gently dips towards the south here and can be seen in the distance on the north side of Cottonwood Canyon, where it eventually is overlain by younger mafic lavas.

The southern stratigraphic transect contains only the upper Littlefield Rhyolite; the lower rhyolite is absent here. The southern transect was performed within Alder Creek Canyon (Figure 25; Figure 27), where the lowest observed stratigraphic unit is the Dinner Creek Tuff, which forms a relatively thick, but poorly-welded pyroclastic deposit (Figure 26). 


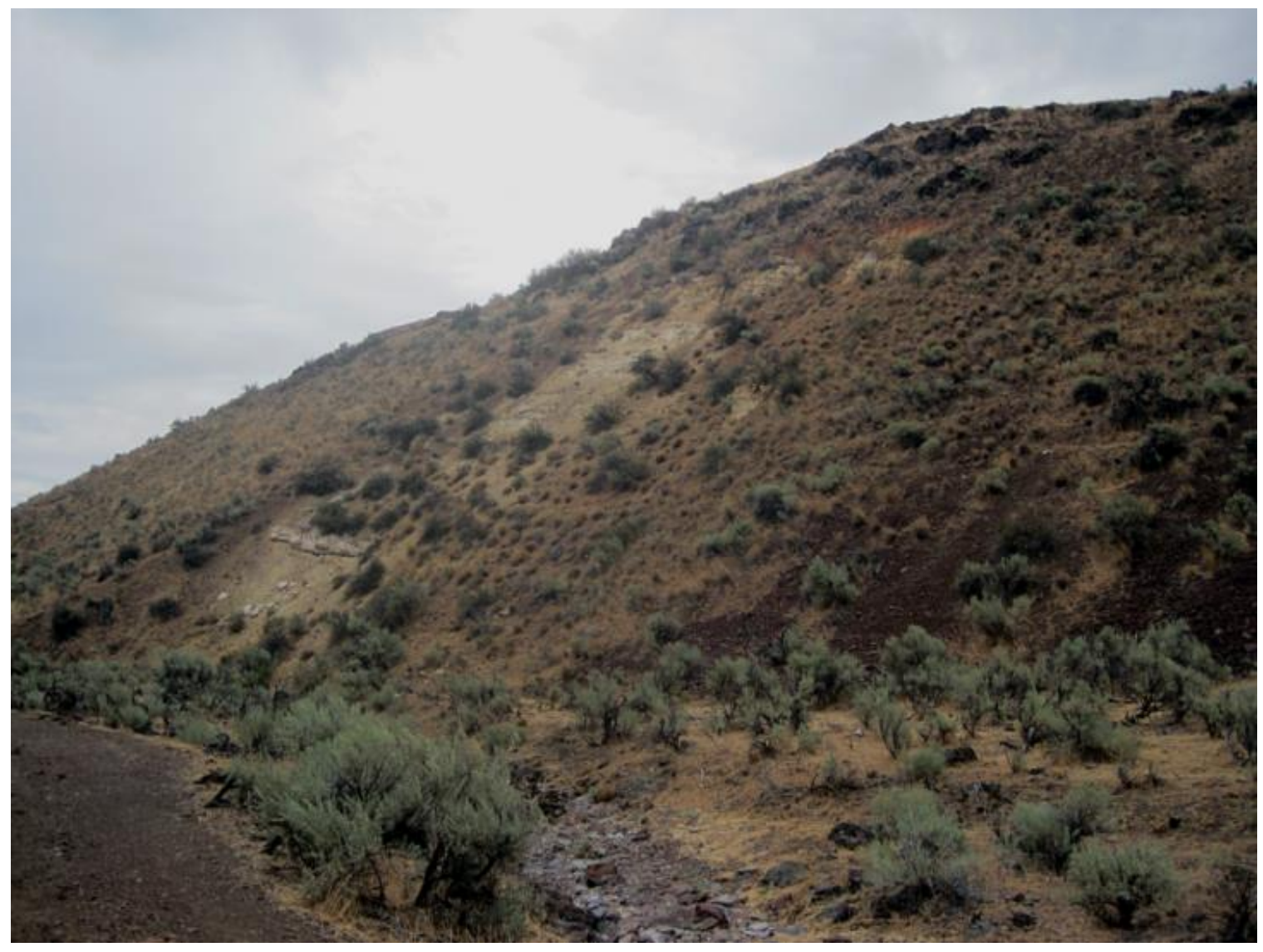

Figure 26: Image shows a rarely observed exposure of Dinner Creek Tuff observed in Alder Creek Canyon. The Dinner Creek Tuff forms a poorly-welded pyroclastic deposit that is relatively thick given its distance from the presumed source area.

Moving upsection, the Dinner Creek Tuff is overlain by an icelandite lava $(\sim 62 \mathrm{wt} . \%$ $\mathrm{SiO}_{2}$ ), which is then overlain by a thin lens of moderately-welded, dacitic tuff that directly underlies the glassy base of the upper Littlefield Rhyolite. The icelandite lava was mapped as Hunter Creek Basalt given their similar lithology and stratigraphic equivalence (Kittleman et al., 1967; Evans \& Binger, 1999f), and although the two units are clearly related, the icelandite is geochemically distinct and may provide evidence of mixing of upper Littlefield Rhyolite and Hunter Creek Basalt magmas. Geochemistry will be discussed later. 


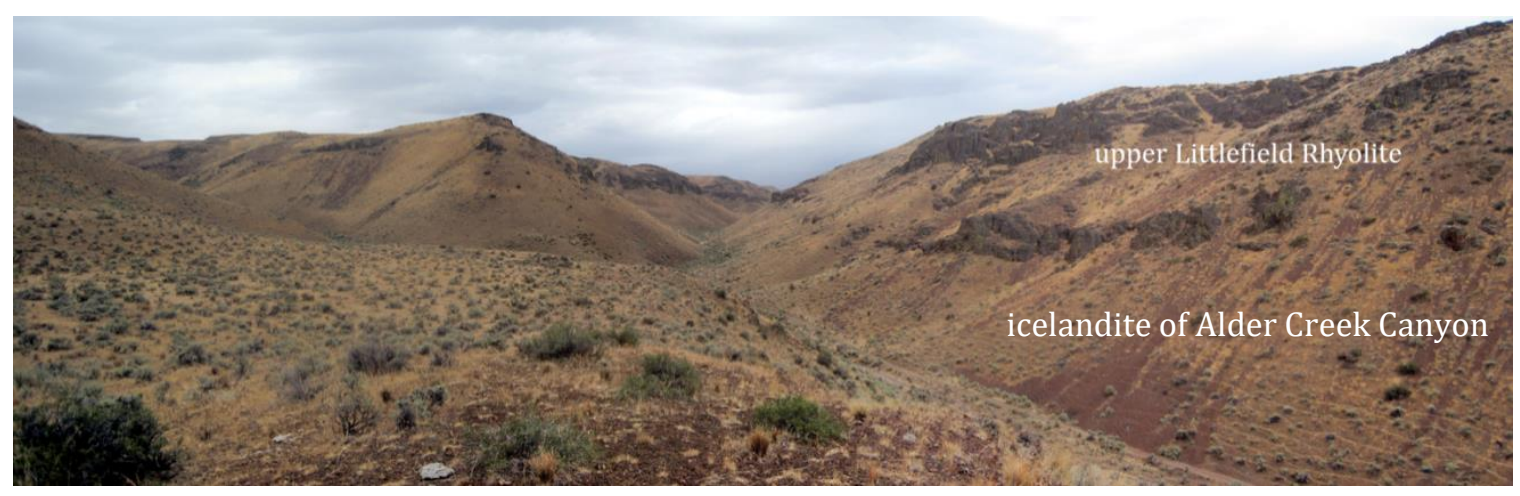

Figure 27: View looking south and upslope within Alder Creek Canyon. The upper Littlefield Rhyolite crops out here. The icelandite lava forms steep, talus dominated slopes that obscure outcrop, including outcrop of the underlying Dinner Creek Tuff.

The petrology and geochemistry of the moderately-welded dacite tuff that underlies the upper Littlefield Rhyolite in the southern transect correlates with the underlying tuff observed in the primary transect within the Malheur River Gorge. In contrast, the lithology of the underlying tuff observed in the southern transect was less disturbed by the emplacement of the upper Littlefield Rhyolite, which shows a complete absence of the basal autobreccia that is commonly observed in the north (Figure 29). In Alder Creek Canyon, the glassy base of the upper Littlefield Rhyolite directly overlies the welded tuff unit (Figure 28). 


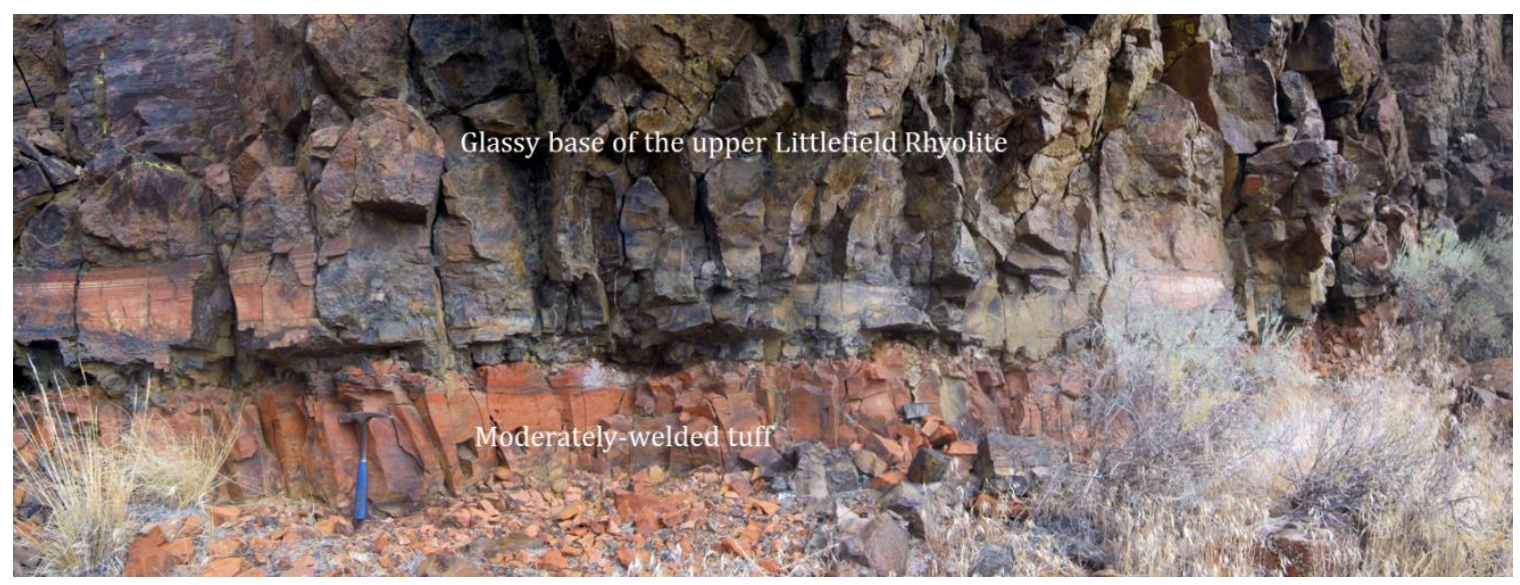

Figure 28: Photograph shows the glassy base of the upper Littlefield Rhyolite, overlying a thin, moderately-welded tuff. Littlefield Rhyolite basal breccia is absent in the south, which likely explains why the underlying tuff is better preserved here, compared to the violence inflicted on the underlying tuff that is observed at Namorf.

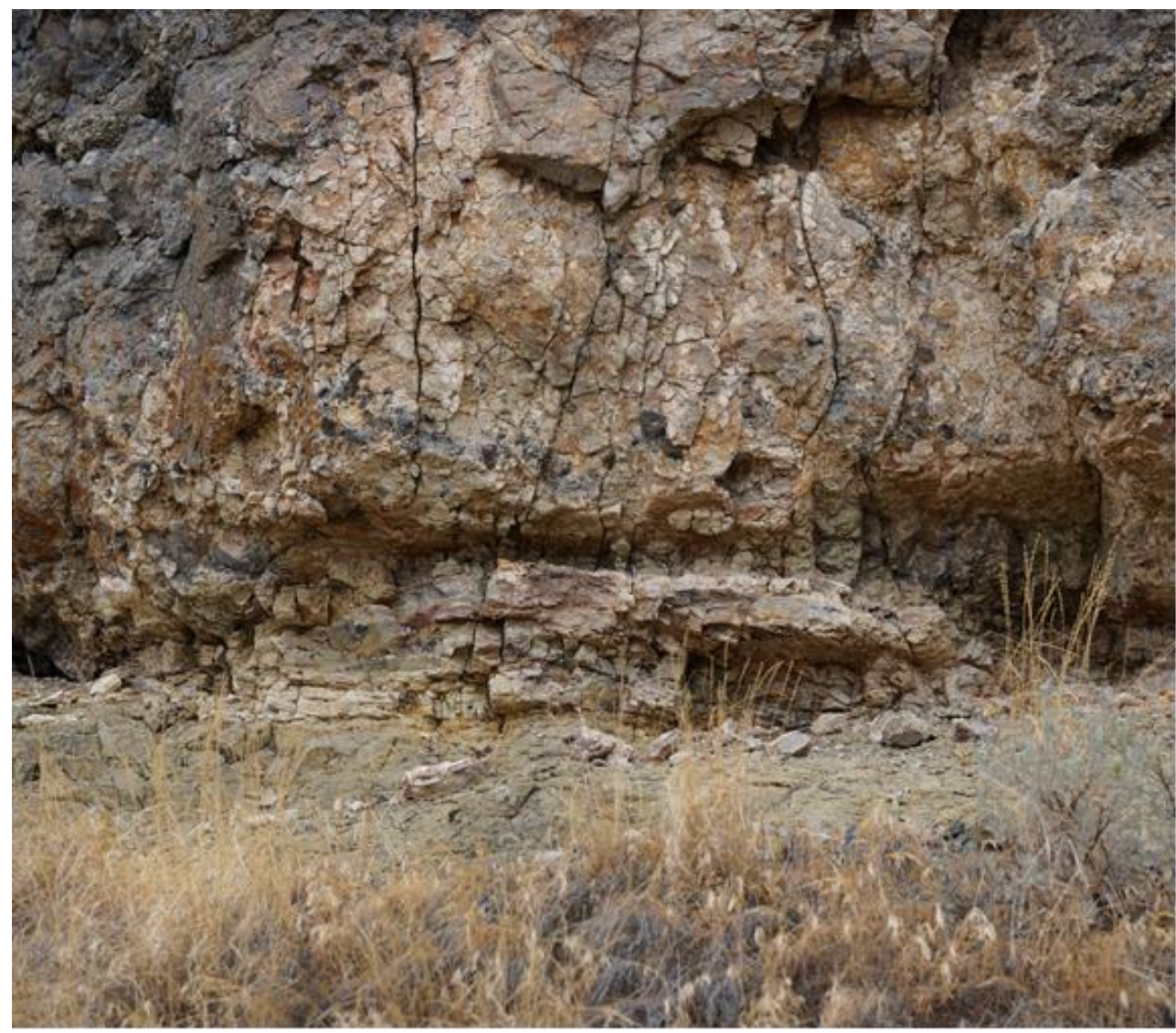

Figure 29: Image shows the base of the upper Littlefield Rhyolite observed within the Malheur River Gorge. A thick section of basal autobreccia overlies a thin lens of dacitic welded tuff, which overlies pyroclastic surge deposits. Some of the light-colored tuffaceous material was abraided during emplacement of the overriding lava flow and incorporated into the matrix of the basal breccia. 


\section{Lithology, Petrography, and Geochemistry of Stratigraphic Units}

The bulk compositions of stratigraphic samples range from basalts to rhyolites

(Figure 30), with the majority of samples being either basaltic andesites or rhyolites

(bimodal). See the appendix for detailed XRF and ICP-MS results, including a sample location map.

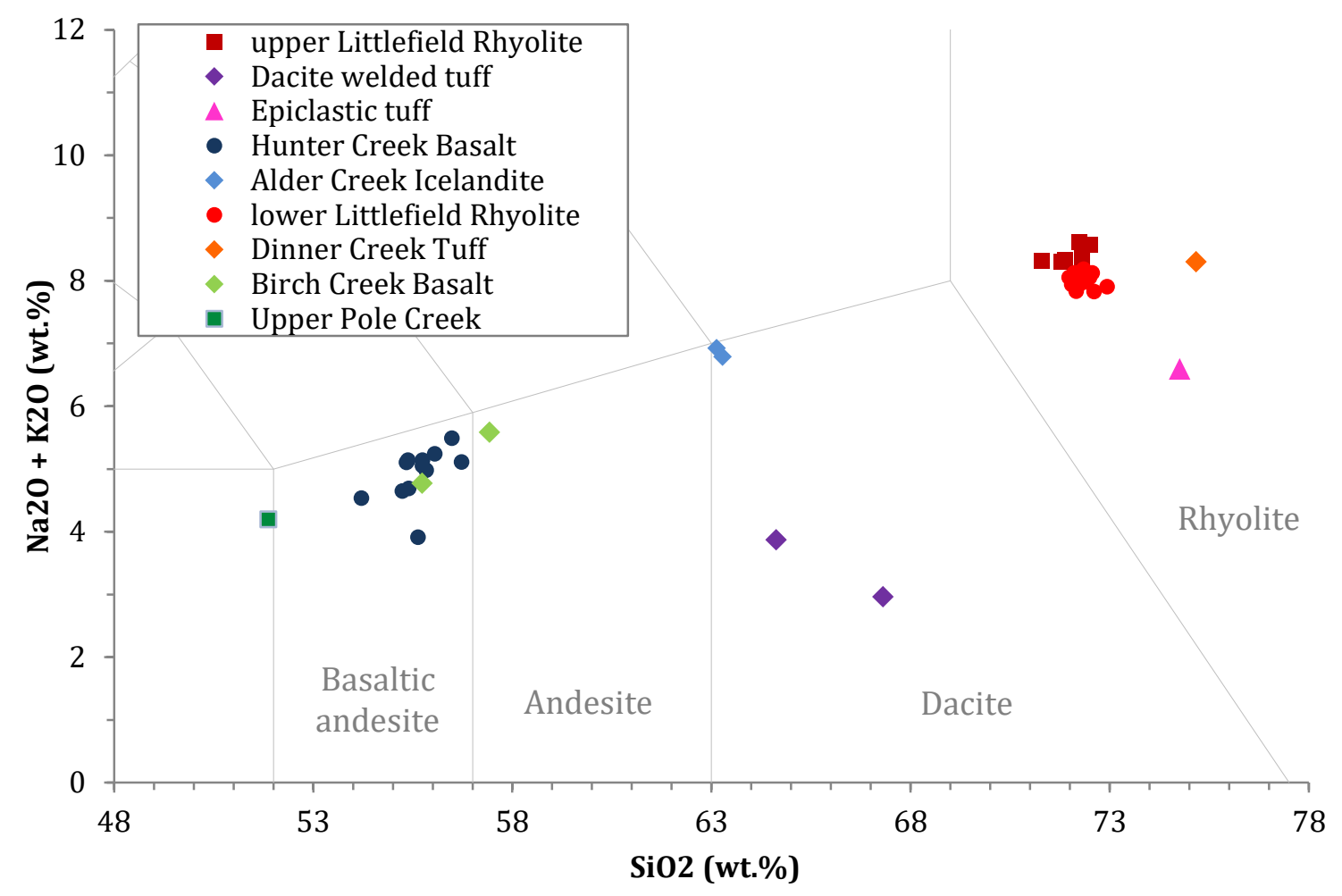

Figure 30: Total Alkali Silica diagram for XRF samples collect for this study.

\section{Littlefield Rhyolites}

Although often indistinguishable in the field, our data reveal that the Littlefield Rhyolite consists of two geochemically distinct rhyolite flow packages that are designated here as lower and upper Littlefield Rhyolite, according to stratigraphic relationships in Malheur River Gorge. Rarely viewed in sequence, these rhyolites are 
distinguished by $\mathrm{Zr}, \mathrm{Ba}, \mathrm{Nb}, \mathrm{TiO}_{2}$ and $\mathrm{FeO}$ contents (Table 2, Figure 31) and ${ }^{40} \mathrm{Ar} /{ }^{39} \mathrm{Ar}$ ages $(16.12 \pm 0.04$ and $16.16 \pm 0.10$ Ma versus $16.01 \pm 0.06$ and $16.05 \pm 0.04$ Ma).

Table 2: XRF data comparing the average major element compositions of six samples of upper Littlefield Rhyolite (upper LFR) and 13 samples of lower Littlefield Rhyolite (lower LFR). In contrast to the underlying tholeiitic lavas, the major and trace element compositions of both Littlefield rhyolites are notably homogenous throughout their extensive thicknesses and relatively widespread emplacements.

\begin{tabular}{cccccccccccc}
\hline \hline $\begin{array}{c}\text { XRF, normalized } \\
w t . \%\end{array}$ & $\mathbf{S i O}_{2}$ & $\mathbf{T i O}_{2}$ & $\mathbf{A l}_{\mathbf{2}} \mathbf{O}_{\mathbf{3}}$ & $\mathbf{F e O}$ & $\mathbf{M n O}$ & $\mathbf{M g O}$ & $\mathbf{C a O}$ & $\mathbf{N a}_{\mathbf{2}} \mathbf{O}$ & $\mathbf{K}_{2} \mathbf{O}$ & $\mathbf{P}_{\mathbf{2}} \mathbf{O}_{\mathbf{5}}$ \\
\hline Maximum & 72.52 & 0.41 & 12.86 & 5.63 & 0.14 & 0.32 & 1.84 & 4.37 & 5.46 & 0.06 \\
\hline $\begin{array}{c}\text { Average upper } \\
\text { LFR }\end{array}$ & 72.01 & 0.40 & 12.53 & 4.97 & 0.12 & 0.15 & 1.35 & 3.75 & 4.66 & 0.05 \\
\hline $\begin{array}{c}\text { Minimum } \\
\text { Maximum }\end{array}$ & 71.30 & 0.36 & 12.35 & 4.24 & 0.08 & 0.07 & 0.98 & 2.91 & 4.09 & 0.04 \\
\hline $\begin{array}{c}\text { Average lower } \\
\text { LFR }\end{array}$ & 72.34 & 0.71 & 12.62 & 4.01 & 0.08 & 0.44 & 1.66 & 2.80 & 5.20 & 0.14 \\
\hline $\begin{array}{c}\text { Minimum } \\
\text { Minim }\end{array}$ & 71.98 & 0.70 & 12.57 & 3.76 & 0.06 & 0.39 & 1.27 & 2.47 & 4.23 & 0.13 \\
\hline
\end{tabular}


- upper Littlefield Rhyolite (average 72.0 wt.\% SiO2)

- lower Littlefield Rhyolite (average 72.3 wt.\% SiO2)
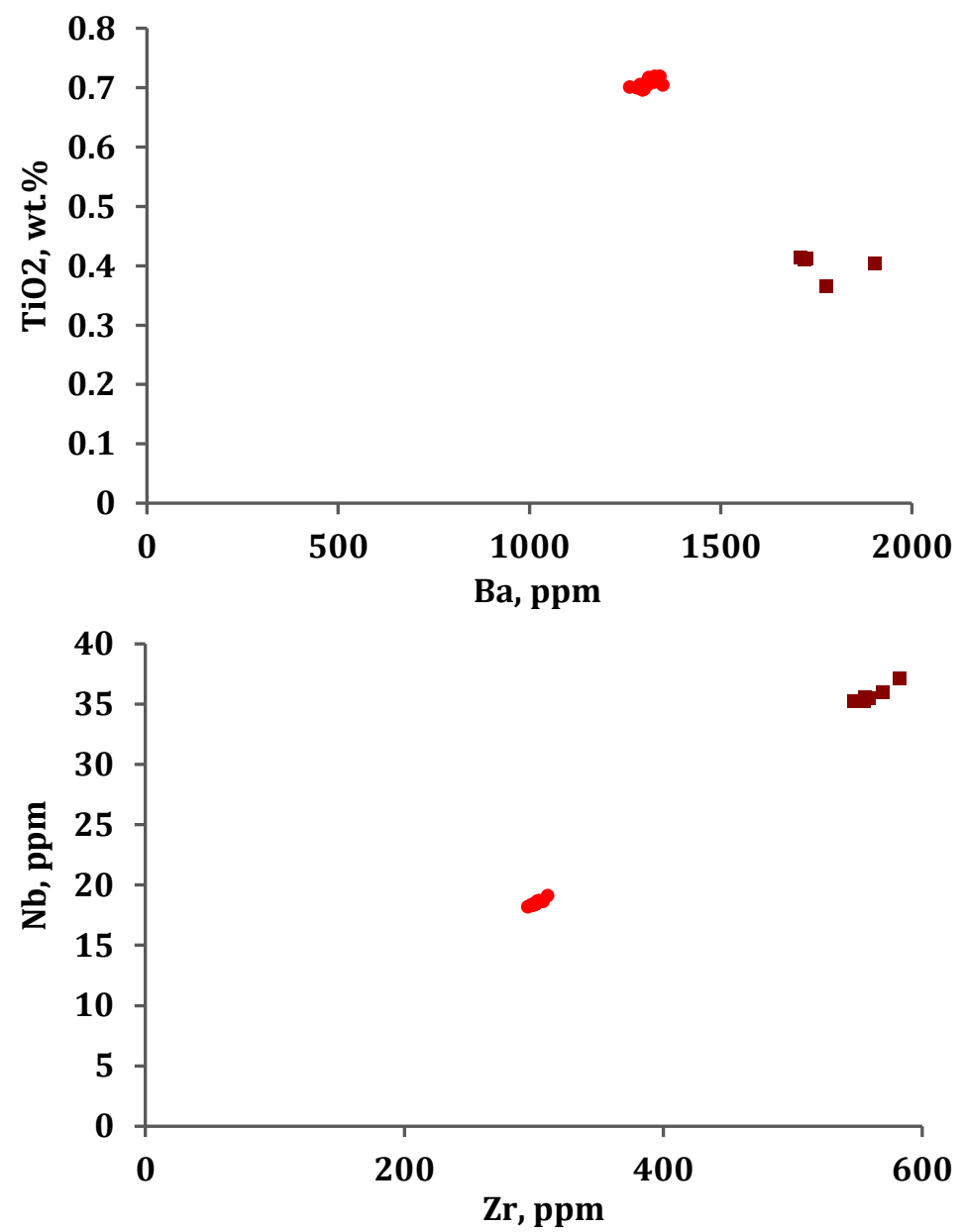

Figure 31: Rhyolite Flow units are distinguished by $\mathrm{Zr}, \mathrm{Ba}, \mathrm{Nb}, \mathrm{TiO} 2$ and $\mathrm{FeO}$ concentrations. The overlying unit possesses relatively higher concentrations of Zirconium, Niobium, and Barium, along with relatively lower concentrations of $\mathrm{TiO}_{2}(\sim 0.4 \mathrm{wt} . \%)$.

Despite their similar appearance in the field and close eruptive timing, major and trace elemental data reveal distinct differences (Figure 32, Figure 33) between these two rhyolites that suggest distinct magmatic histories (Figure 34). 


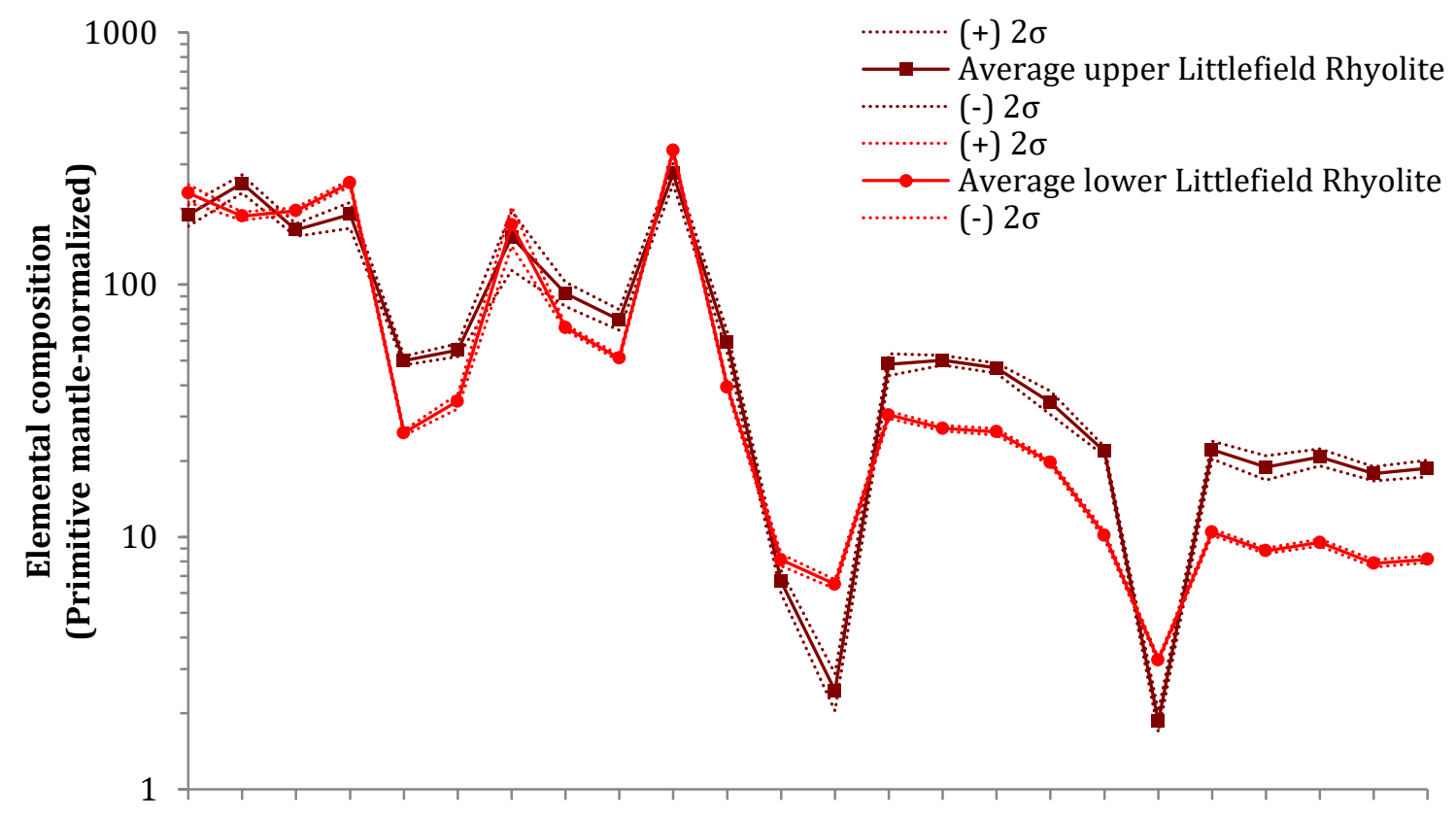

Rb Ba Th U Nb Ta K La Ce Pb Pr Sr P Nd Zr Hf Sm Eu Ti Dy Y Ho Yb Lu

Figure 32: Primitive mantle-normalized element composition of the upper and lower Littlefield rhyolites. The upper Littlefield Rhyolite has relatively higher concentrations of most trace elements, with the exception of $\mathrm{Ti}, \mathrm{P}, \mathrm{Sr}, \mathrm{Pb}, \mathrm{K}, \mathrm{U}$, Th, and $\mathrm{Rb}$. The less incompatible elements appear to follow a similar trend, which is not as apparent between elements of increased incompatibility. Normalization values from Sun \& McDonough (1989).

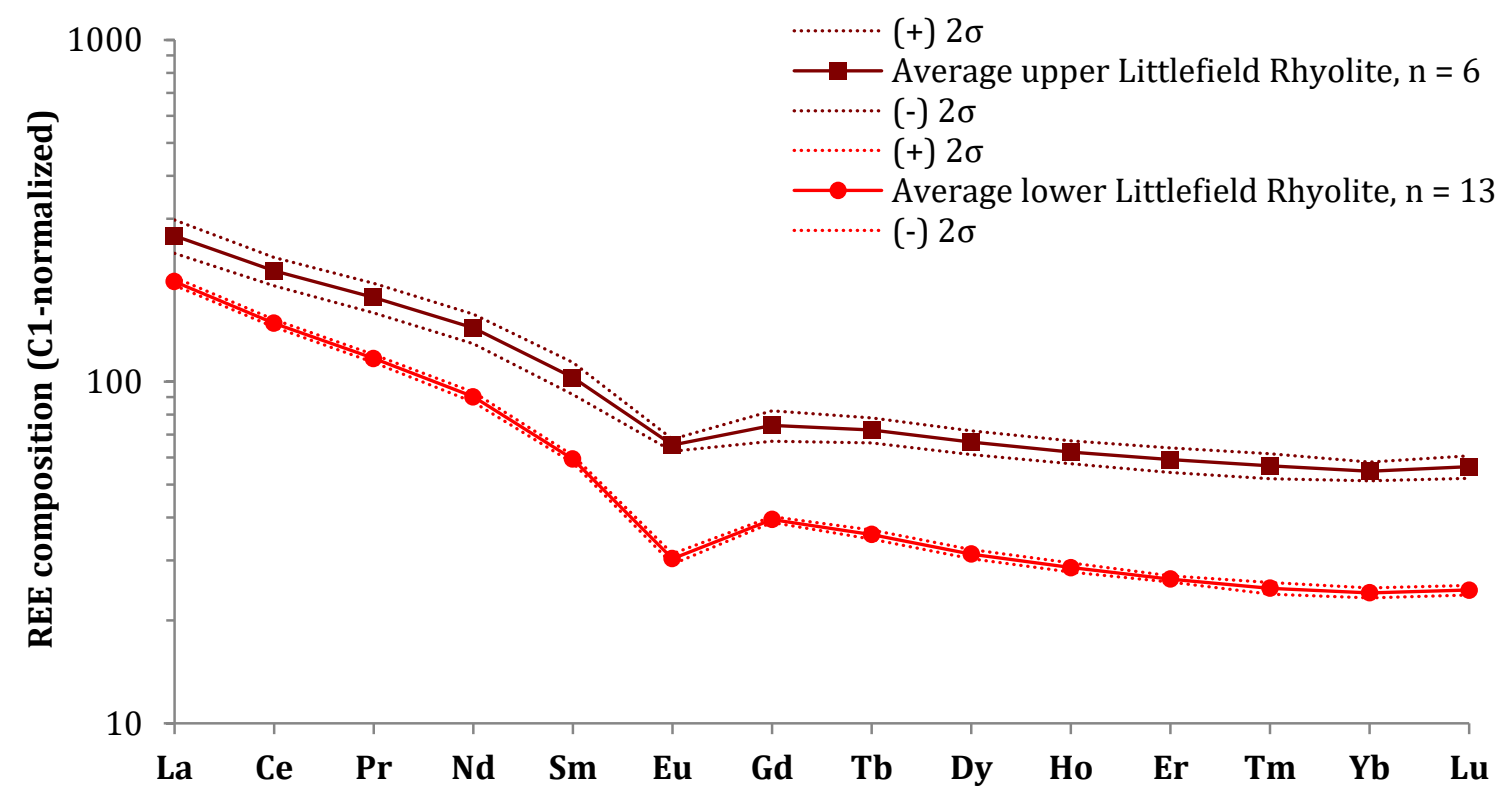

Figure 33: C1-normalized REE compositions of the upper and lower Littlefield rhyolites. The upper Littlefield Rhyolite has relatively higher concentrations of rare-earth elements (REE) and less depletion of Eu. Normalization values from Sun \& McDonough (1989). 


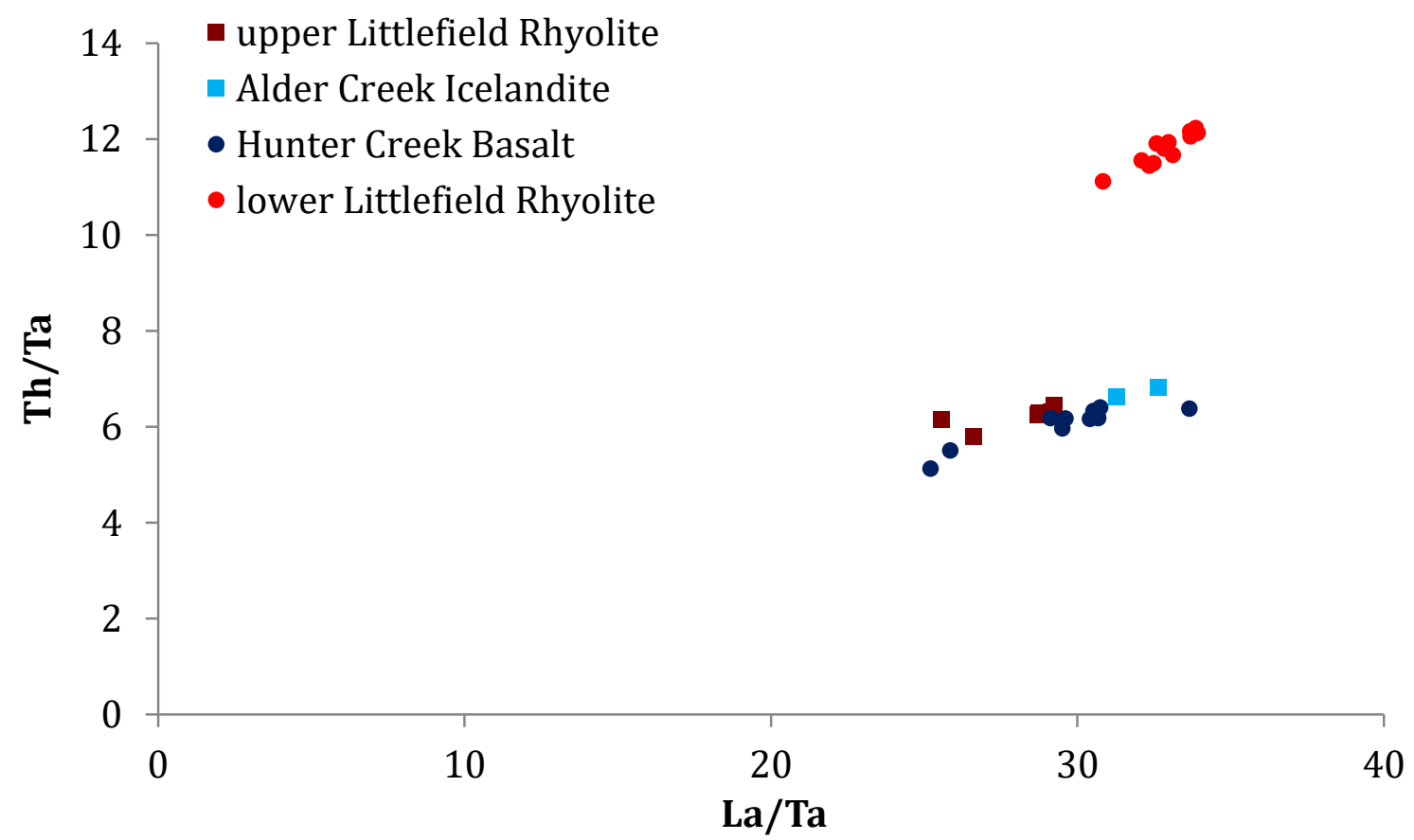

Figure 34: Th/Ta generally increases with increasing crustal contamination. The plot of Th/Ta versus La/Ta shows that lower Littlefield Rhyolite appears relatively distinct from the upper Littlefield Rhyolite. Additionally, upper Littlefield Rhyolite appears similar to the Hunter Creek Basalt and icelandite of Alder Creek Canyon. This suggests that the upper and lower Littlefield Rhyolites have distinct petrogenetic histories.

Rhyolites known either as 'rhyolite of Cottonwood Mountain', or 'rhyolite of Bully Creek Canyon', and which are exposed around Cottonwood Mountain, northwest of Vale, have similar compositions to samples of what we refer to here as lower Littlefield Rhyolite. Additionally, single crystal ${ }^{40} \mathrm{Ar} /{ }^{39} \mathrm{Ar}$ ages of two samples $(16.12 \pm 0.07,16.20 \pm 0.08)$ are statistically indistinguishable. This evidence supports the stratigraphic correlation of lower Littlefield Rhyolite, which erupted from vents observed within the Malheur River Gorge, with rhyolites exposed at Cottonwood Mountain, to the northwest. 


\section{Upper Littlefield Rhyolite}

Upper Littlefield Rhyolite outcrop lithology consists of massive, platey-jointed, or columnar jointed (Figure 35), glassy black to dark-grey vitrophyre, or incipiently devitrified rhyolite.

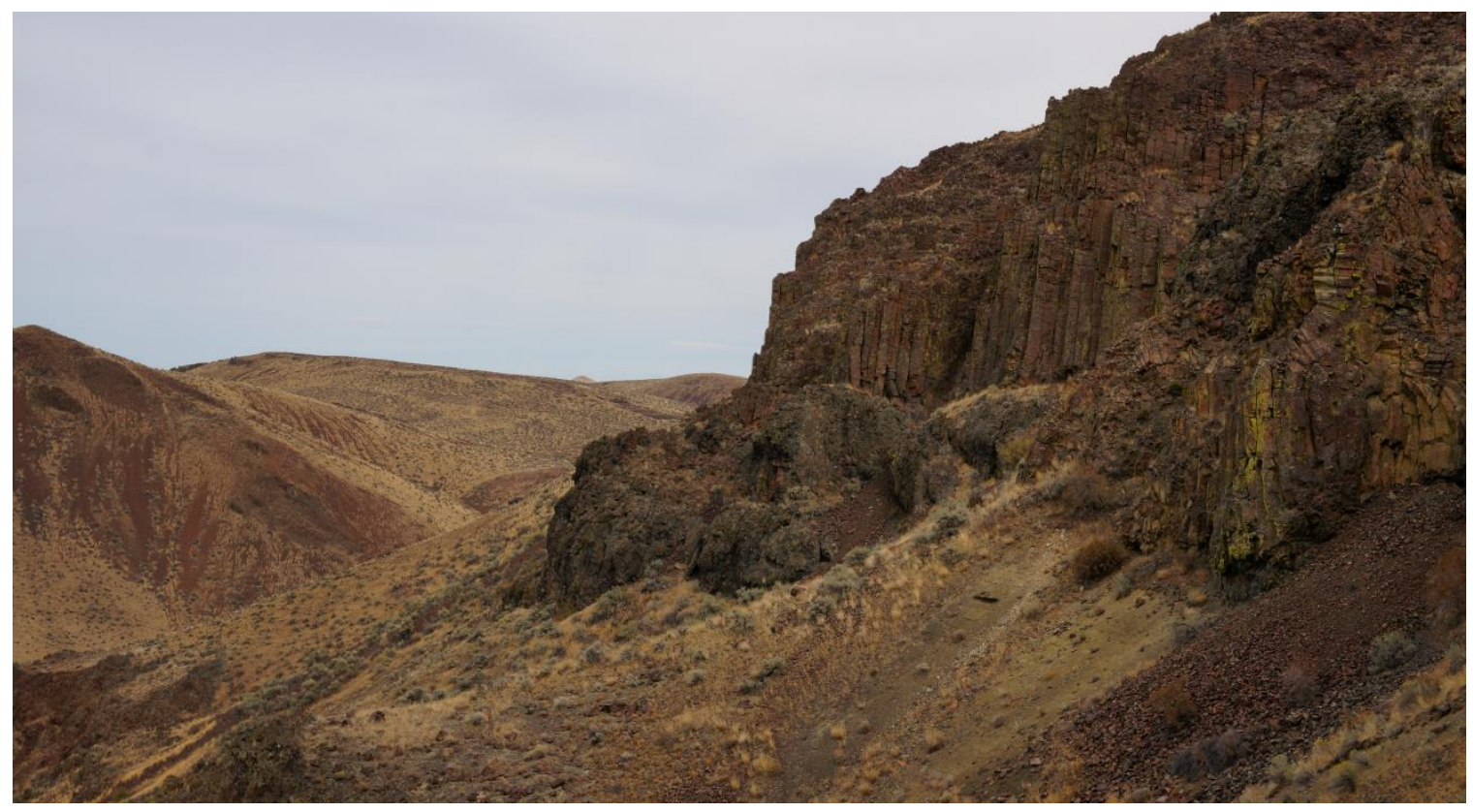

Figure 35: Photograph of an upper Littlefield Rhyolite outcrop showing columnar jointing above basal autobreccia.

Incipiently devitrified rhyolite appears glassy when observed in the field, but reveals the initial stages of groundmass devitrification when viewed in thin-section. This is a common form of rhyolite observed in the field, and is in contrast to less commonly observed rhyolite that is truly glassy, or rhyolite that is unambiguously lithoidal.

The base of the upper Littlefield Rhyolite can alternate between thick zones of basal autobreccia, or glassy basal vitrophyre that forms a stark lower contact. Light-grey, sometimes grey-violet and with light-pink colored banding, devitrified rhyolite is 
commonly observed as talus, uncommonly preserved in outcrop, and is presumably remnants from the now eroded upper section of the flow. Weathered surfaces of lithoidal rhyolite are typically brick-red to brownish-red in color. In contrast to the lower Littlefield Rhyolite, flow banding is rarely observed.

Samples were porphyritic with approximately $8-12 \%$ phenocrysts, commonly cumulophyric, containing subhedral and euhedral plagioclase feldspar (Or6-14, $\mathrm{An}_{16-}$

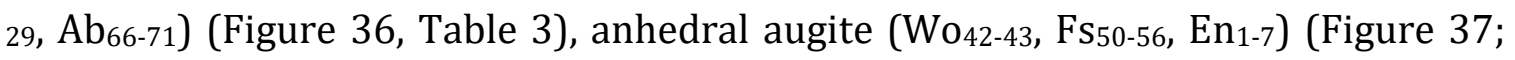
Table 4), titanomagnetite, and ubiquitous apatite microlites, within either a vitrophyric, hyalopilitic, hypohyaline, or incipiently devitrified groundmass (Figure 38). Brown-colored melt inclusions within feldspar phenocrysts are common, and uncommonly appear pervasive within individual crystals. 


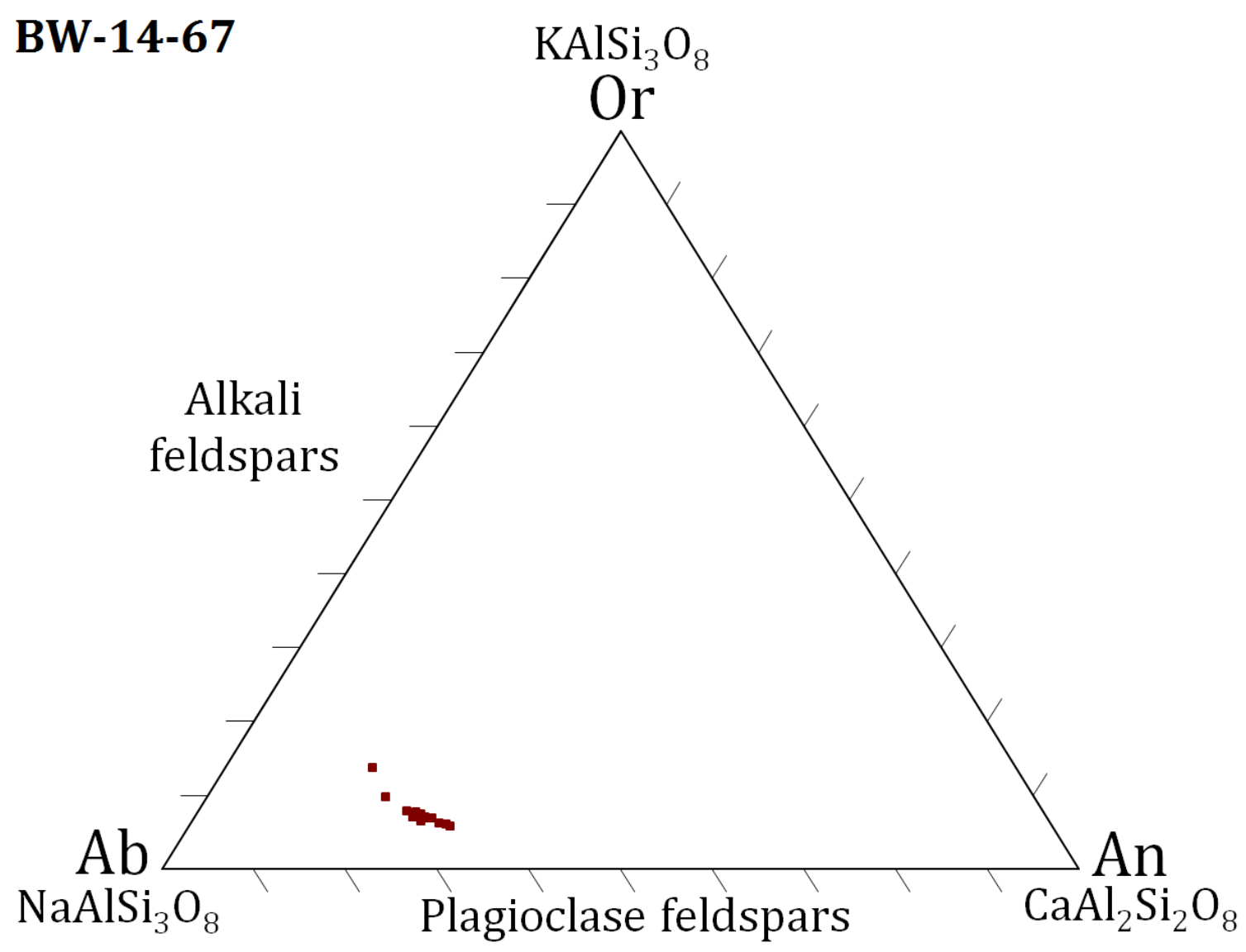

Figure 36: Ternary plot shows the range of calculated end-member compositions from electron Microprobe (EMP) analyses of upper Littlefield Rhyolite feldspar phenocrysts. Upper Littlefield Rhyolite sample number: BW-14-67.

Table 3: The average, minimum, and maximum calculated end-member compositions from electron Microprobe (EMP) analyses of upper Littlefield Rhyolite feldspar phenocrysts. Upper Littlefield Rhyolite sample number: BW-14-67.

\begin{tabular}{cccc}
\hline \hline BW-14-67 & \%Or & \%An & \%Ab \\
\hline Max & 13.83 & 28.50 & 70.70 \\
Mean & 7.51 & 24.38 & 68.10 \\
Min & 5.81 & 15.98 & 65.69 \\
\hline
\end{tabular}




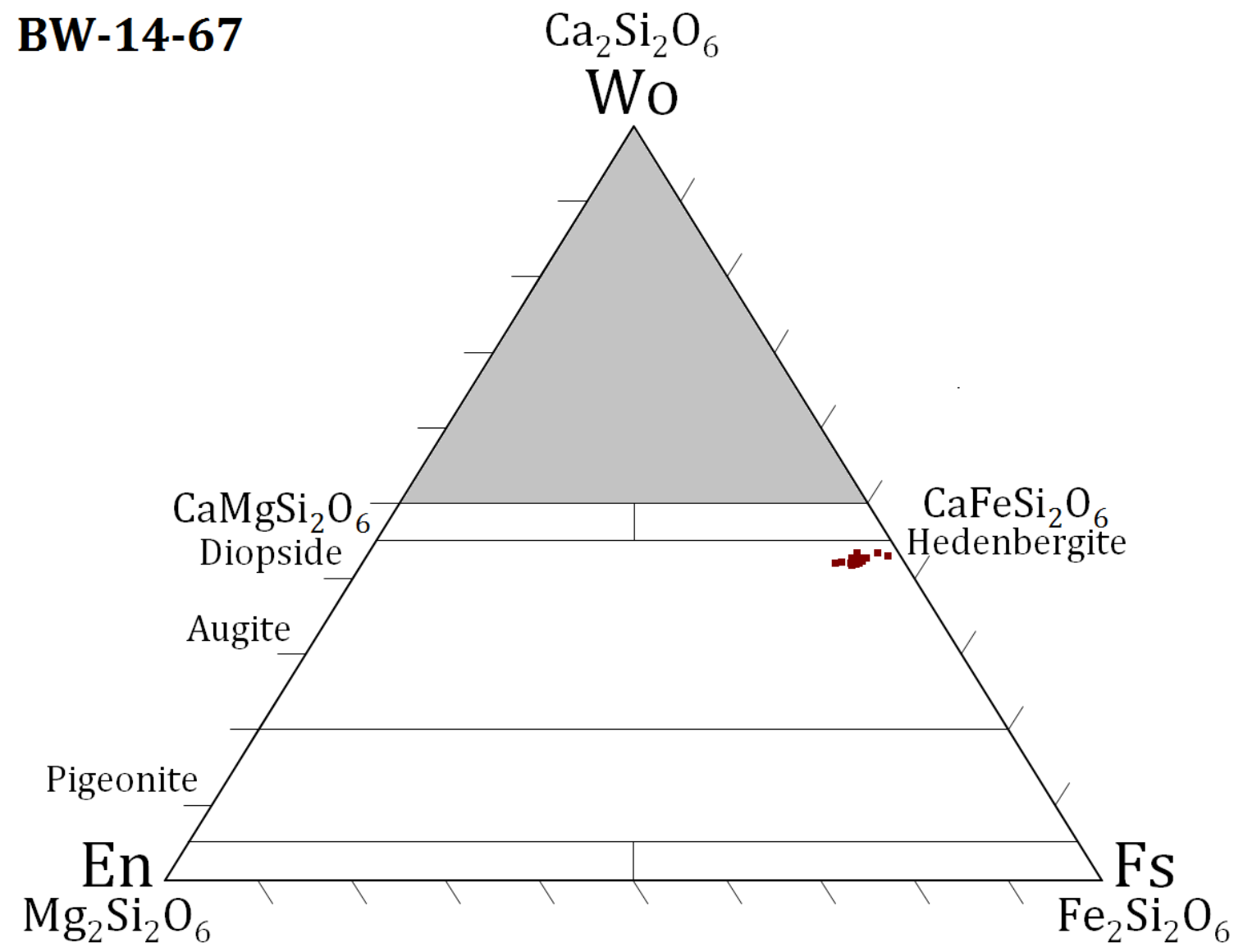

Figure 37: Ternary plot shows the range of calculated end-member compositions from electron Microprobe (EMP) analyses of upper Littlefield Rhyolite pyroxene phenocrysts. Upper Littlefield Rhyolite sample number: BW-14-67.

Table 4: The average, minimum, and maximum calculated end-member compositions from electron Microprobe (EMP) analyses of upper Littlefield Rhyolite pyroxene phenocrysts. Upper Littlefield Rhyolite sample number: BW-14-67.

\begin{tabular}{cccc}
\hline \hline BW-14-67 & \%Wo & \%Fs & \%En \\
\hline Max & 43.44 & 55.61 & 7.45 \\
Mean & 42.47 & 52.64 & 4.89 \\
Min & 41.84 & 50.49 & 1.40 \\
\hline
\end{tabular}


Table 5: Composition of titanomagnetite phenocrysts in sample BW-14-67, including small amounts of Mg and Mn. *Solid-solution of $\mathrm{FeO}$ and $\mathrm{Fe}_{2} \mathrm{O}_{3}$.

\begin{tabular}{ccccc}
\hline \hline BW-14-67 & \%Ti & \%Fe* & \%Mg & \%Mn \\
\hline Max & 37.83 & 78.34 & 0.53 & 1.04 \\
Mean & 26.57 & 72.23 & 0.28 & 0.92 \\
Min & 20.55 & 60.84 & 0.13 & 0.76 \\
\hline
\end{tabular}

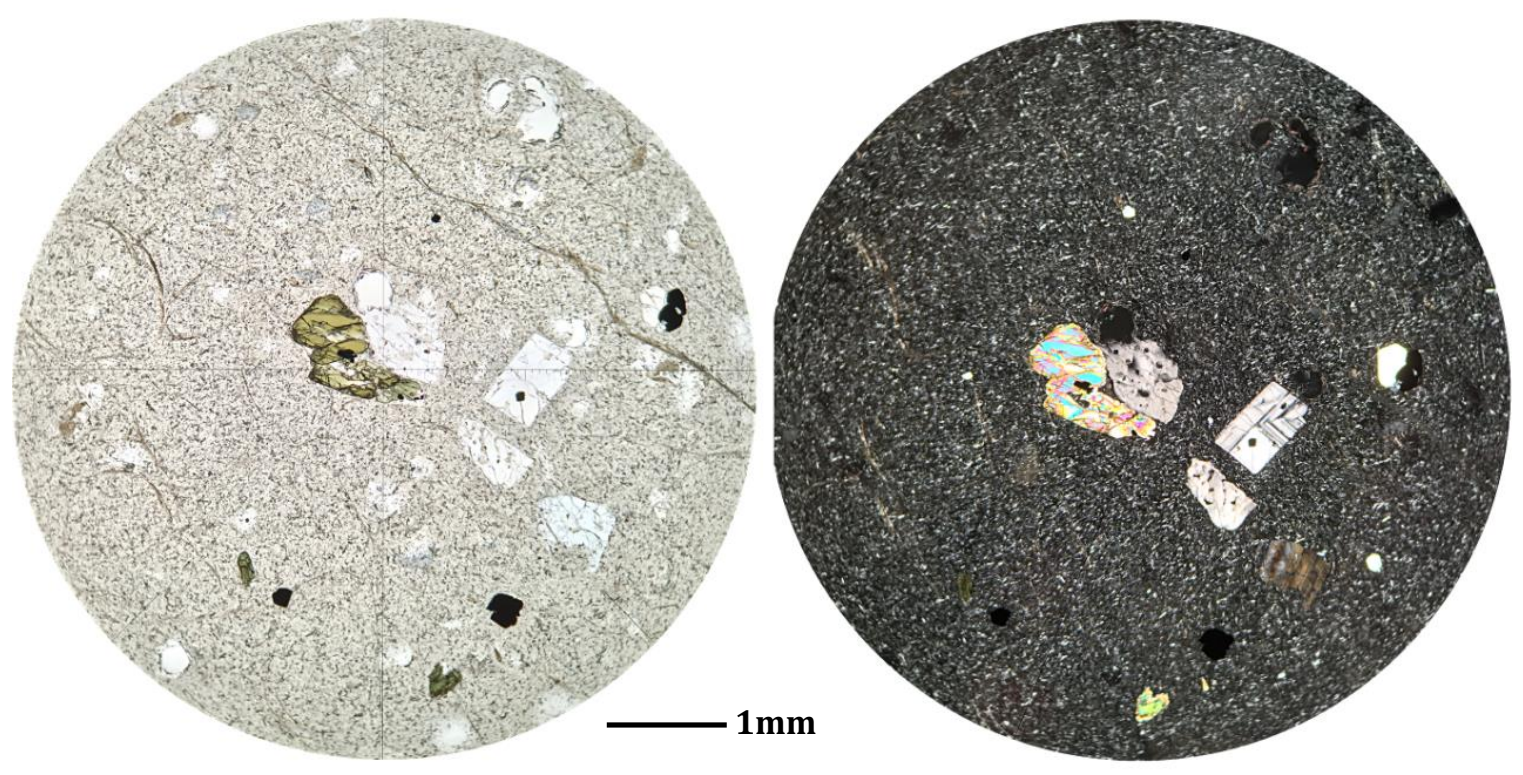

Figure 38: Photomicrographic image of upper Littlefield Rhyolite, showing feldspar, pyroxene, and titanomagnetite phenocrysts, within a vitric groundmass containing scattered crystallites. 


\section{Lower Littlefield Rhyolite}

The lower Littlefield Rhyolite (Figure 39) has been given different names in different areas by different researchers. These names include the lower Littlefield Rhyolite (Lees, 1994), the Rhyolite of Bully Creek Canyon (Brooks and O'Brien, 1990), and the Rhyolite of Cottonwood Mountain (Hooper et al., 2002; Cummings et al., 2000; Evans, unpublished mapping of the Swede Flat).

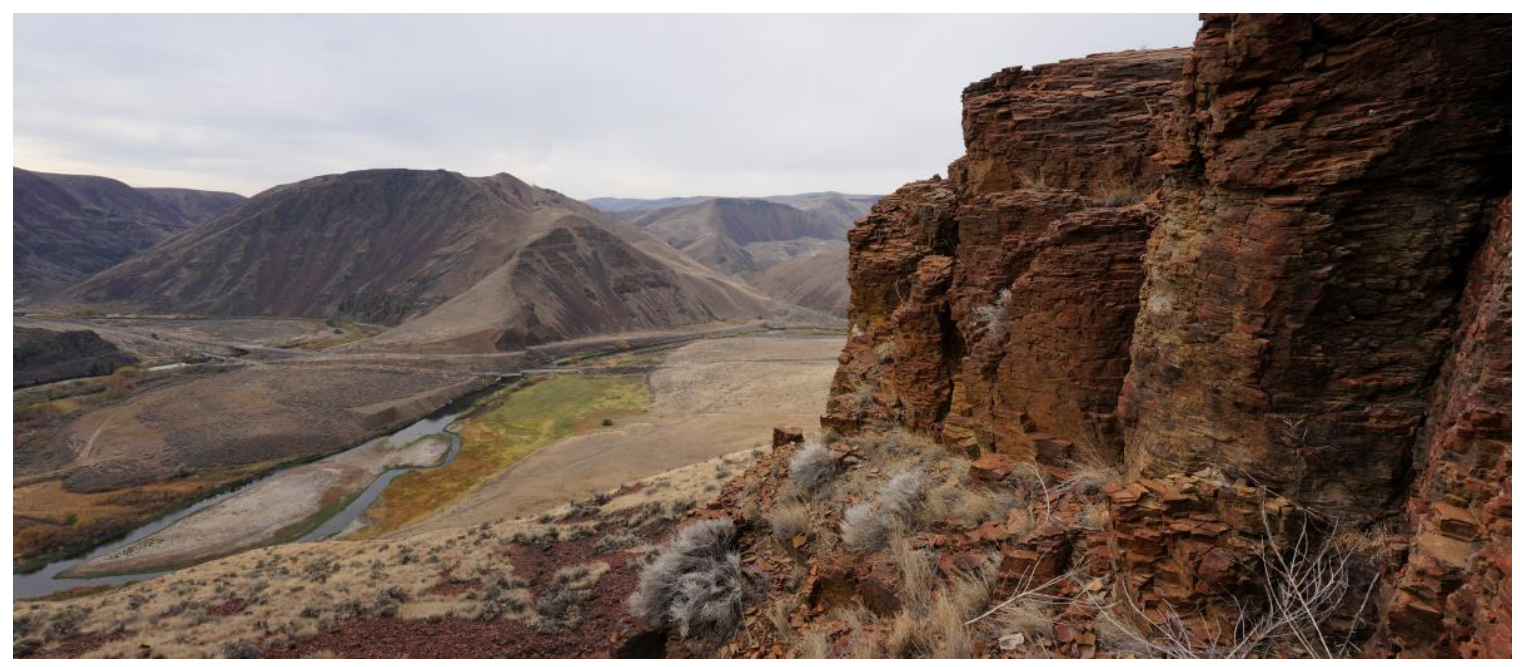

Figure 39: Photograph of a platey-jointed outcrop of lower Littlefield Rhyolite overlooking the Malheur River.

Outcrops commonly reveal upper and lower flow sections composed of glassy, black to dark-grey vitrophyre, with dense, lithoidal, platey-jointed, central flow section. Upper flow contacts are typically vesicular and appear to be very well preserved, implying that the overlying Hunter Creek Basalt was emplaced relatively soon after emplacement of the lower Littlefield Rhyolite. The central flow section typically consists of dense, massive, platy-jointed, incipiently-devitrified to devitrified rhyolite, with sparse bands of $\sim 1 \mathrm{~cm}$ diameter spherulites. Atypical exposures observed within the Malheur River Gorge display steeply ramped and chaotic flow 
banding. Uncommonly observed masses of rhyolite autobreccia do not clearly appear to coincide with flow contacts. Weathered surfaces of dense, devitrified rhyolite are brownish-red to brownish-orange in color. Incipiently devitrified petrographic samples sometimes contain micro-spherulites that do not appear to be aligned along flow bands.

Petrographic samples are porphyritic, commonly cumulophyric, containing broken subhedral and euhedral plagioclase feldspar ( $\left.\mathrm{Or}_{3-5}, \mathrm{An}_{36-46}, \mathrm{Ab} 51-59\right)$ (Figure 40, Table 6) subhedral pigeonite (Wo8-11, Fs51-54, En 36-40) (Figure 41, Table 7), euhedral apatite, and titanomagnetite (Table 8), within either a vitrophyric, hyalopilitic, or incipiently devitrified groundmass (Figure 42). Incipiently devitrified samples uncommonly contain sparse microspherulites. Feldspars commonly contain melt inclusions (Figure 43). Apatite microlites are ubiquitous throughout all samples (Figure 44). 


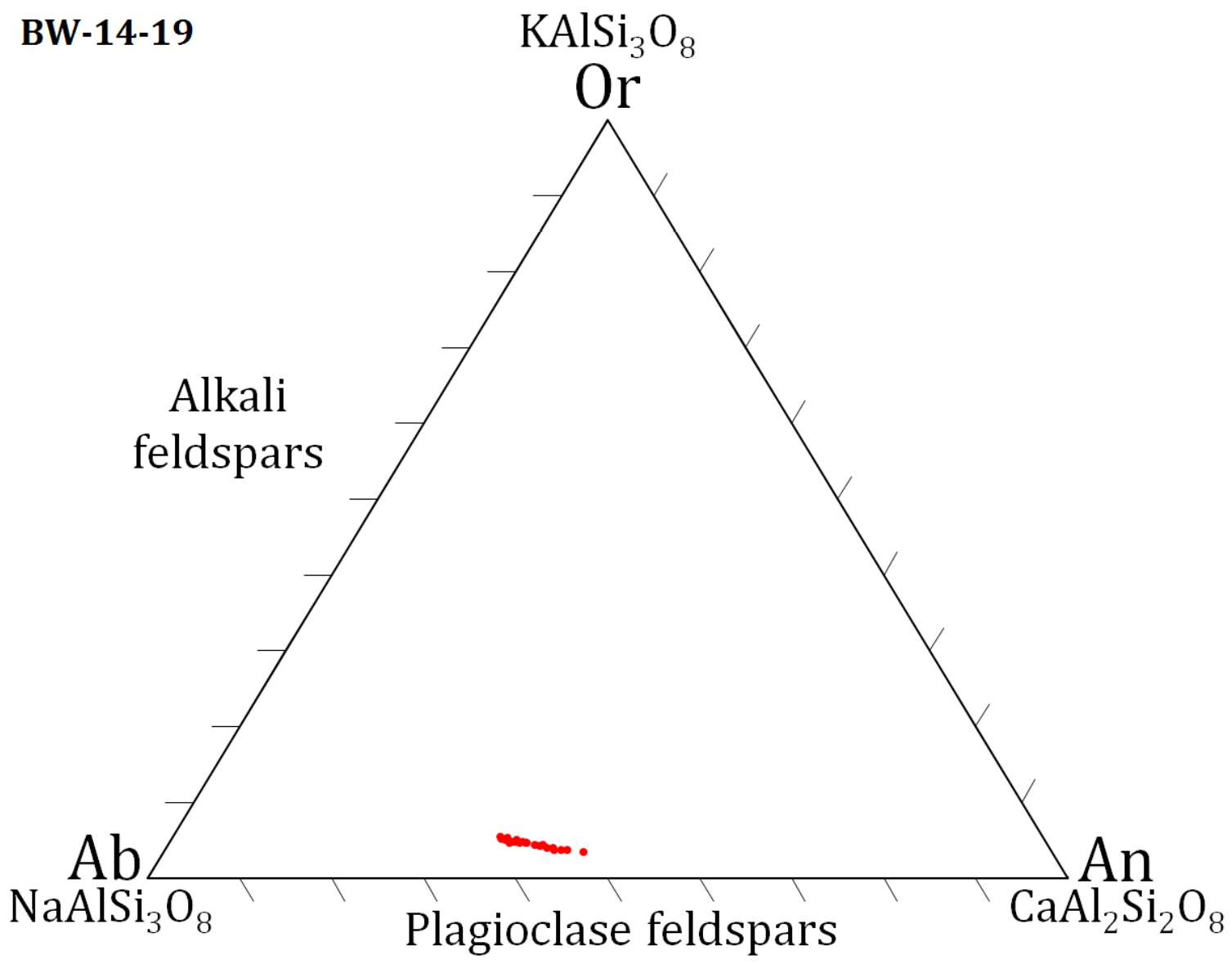

Figure 40: Ternary plot shows the range of calculated end-member compositions from electron Microprobe (EMP) analyses of lower Littlefield Rhyolite feldspar phenocrysts. Lower Littlefield Rhyolite sample number: BW-14-19.

Table 6: The average, minimum, and maximum calculated end-member compositions from electron Microprobe (EMP) analyses of lower Littlefield Rhyolite feldspar phenocrysts. Lower Littlefield Rhyolite sample number: BW-14-19.

\begin{tabular}{cccc}
\hline \hline BW-14-19 & \%Or & \%An & \%Ab \\
\hline Max & 5.38 & 45.75 & 58.86 \\
Mean & 4.46 & 39.50 & 56.04 \\
Min & 3.37 & 35.79 & 50.89 \\
\hline
\end{tabular}




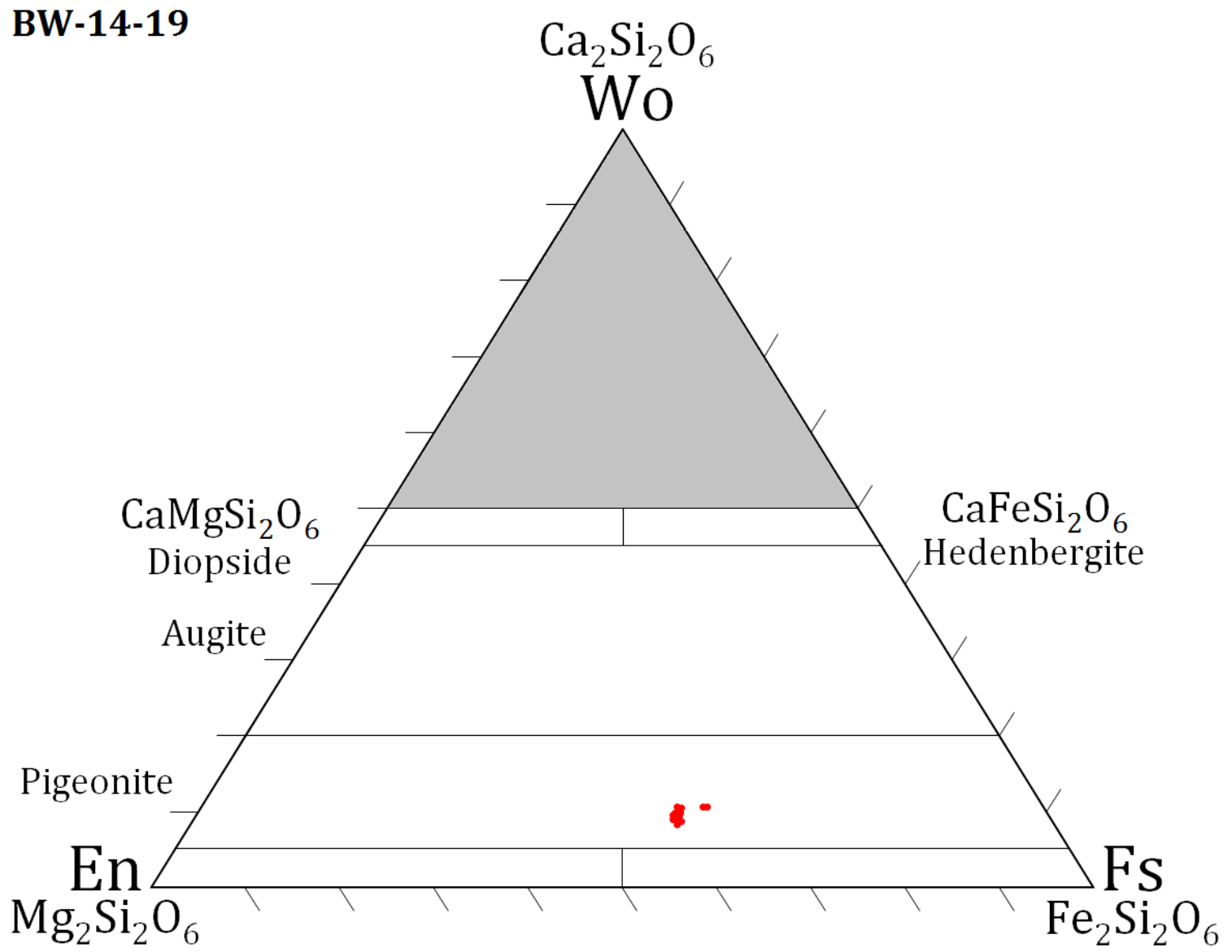

Figure 41: Ternary plot shows the range of calculated end-member compositions from electron Microprobe (EMP) analyses of lower Littlefield Rhyolite pyroxene phenocrysts. Lower Littlefield Rhyolite sample number: BW-14-19.

Table 7: The average, minimum, and maximum calculated end-member compositions from electron Microprobe (EMP) analyses of lower Littlefield Rhyolite pyroxene phenocrysts. Lower Littlefield Rhyolite sample number: BW-14-19.

\begin{tabular}{cccc}
\hline \hline BW-14-19 & \%Wo & \%Fs & \%En \\
\hline max & 10.65 & 53.71 & 40.17 \\
mean & 9.69 & 51.23 & 39.08 \\
min & 8.30 & 50.50 & 35.66 \\
\hline
\end{tabular}

Table 8: The average, minimum, and maximum composition of titanomagnetite phenocrysts derived from electron microprobe analyses. *Solid-solution of $\mathrm{FeO}$ and $\mathrm{Fe}_{2} \mathrm{O}_{3}$.

\begin{tabular}{ccccc}
\hline \hline BW-14-19 & \%Ti & \%Fe* & \%Mg & \%Mn \\
\hline Max & 27.75 & 76.27 & 2.07 & 3.35 \\
Mean & 24.05 & 72.74 & 1.76 & 1.45 \\
Min & 20.98 & 69.68 & 0.95 & 0.79 \\
\hline
\end{tabular}



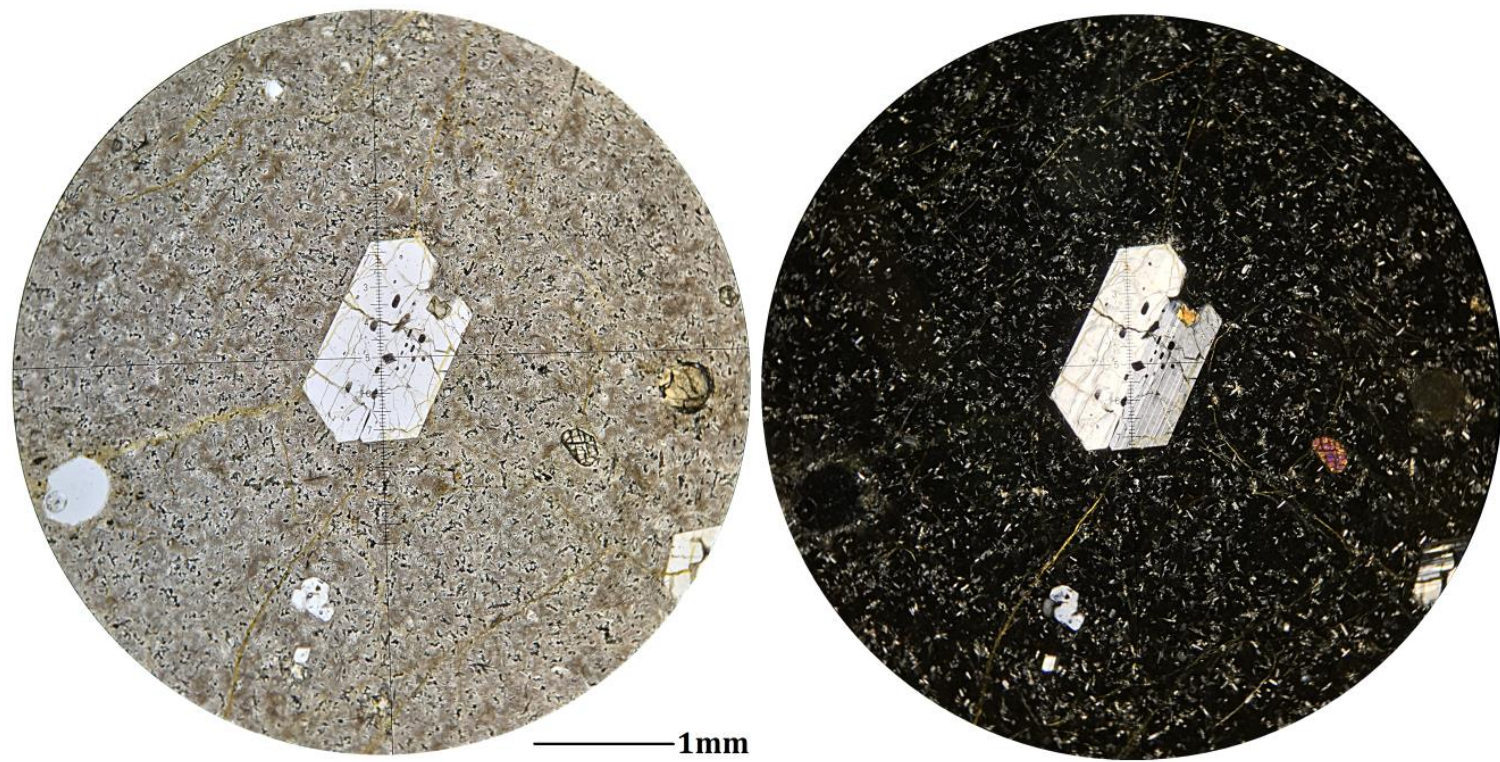

Figure 42: Photomicrographic image of lower Littlefield Rhyolite, showing feldspar and pyroxene phenocrysts within a vitric groundmass containing scattered crystallites.
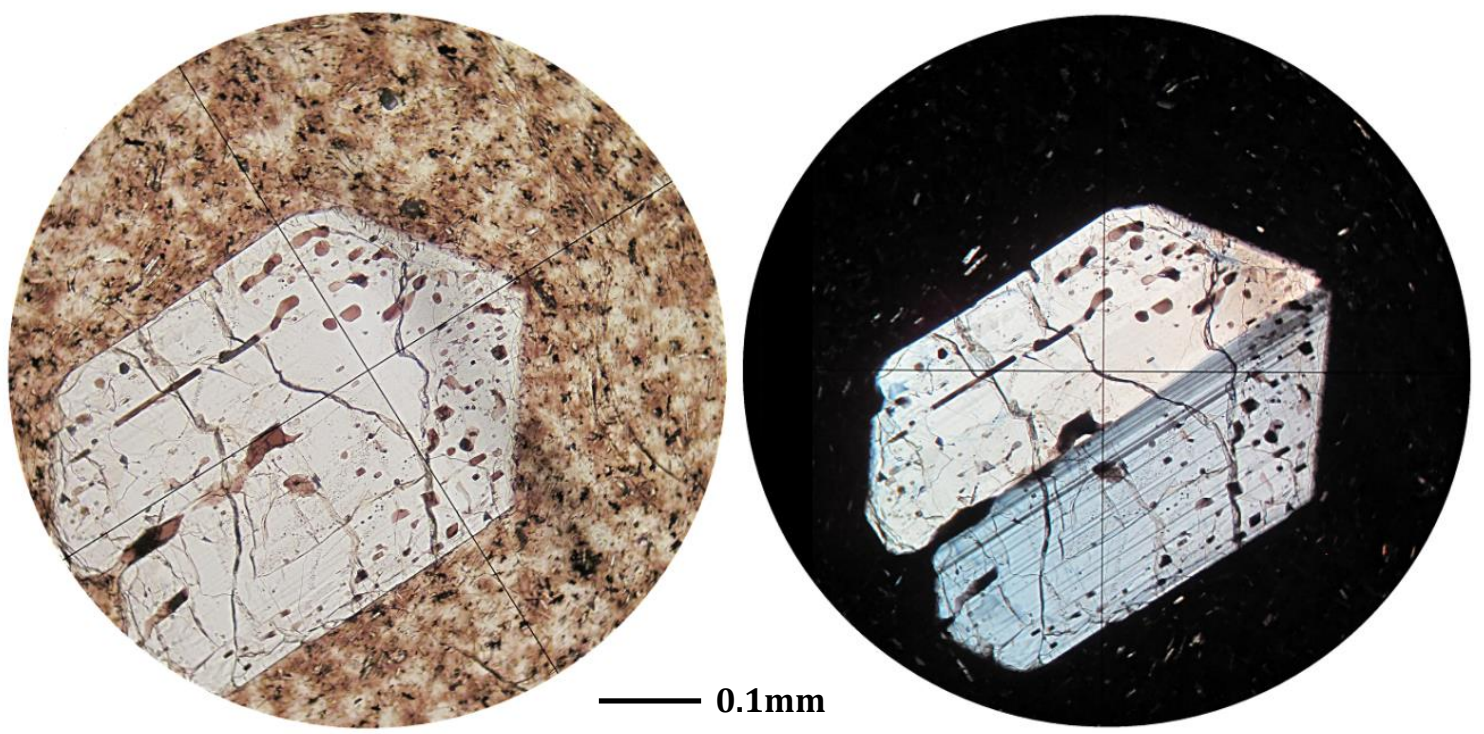

Figure 43: Photomicrographic image of lower Littlefield Rhyolite, showing brown-colored melt inclusions that are commonly observed within feldspar phenocrysts. Vitric groundmass contains scattered crystallites. 

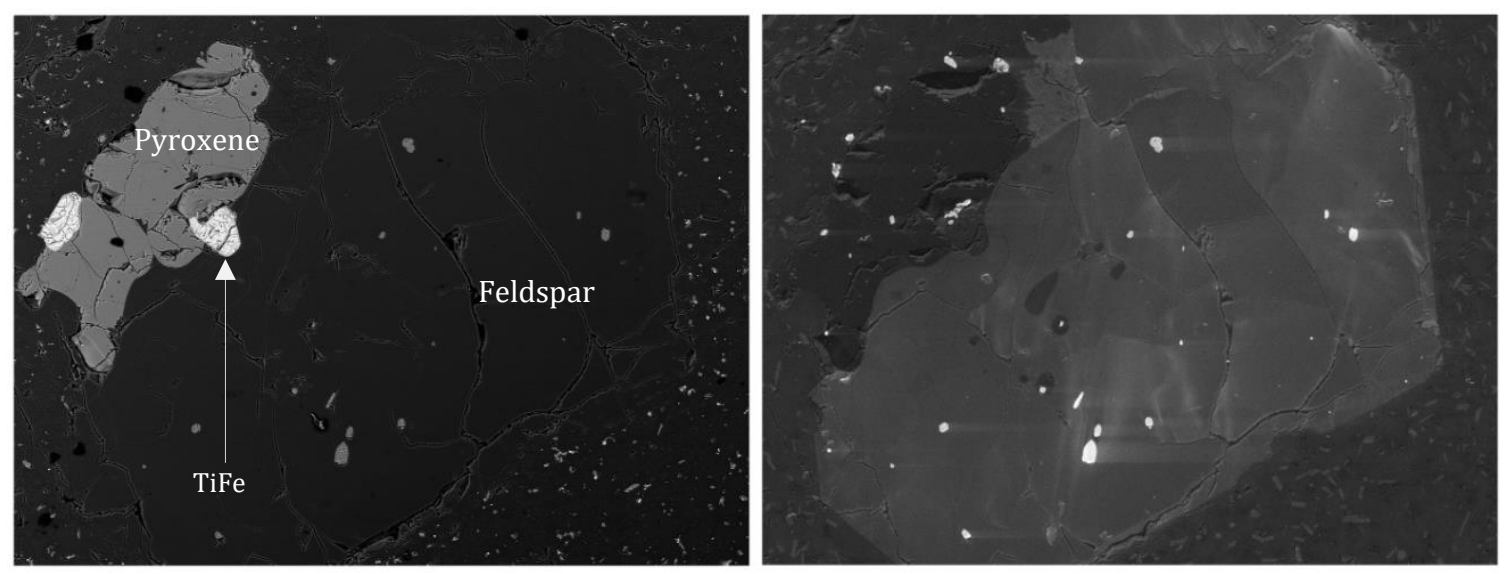

Figure 44: SEM imagery highlights the presence of apatite within a lower Littlefield Rhyolite sample. A back-scatter Electron (BSE) image on the left shows titanium magnetite, pyroxene, and feldspar phenocrysts surrounded by a matrix of glass and crystallites. Feldspar appears to be in equilibrium with the surrounding groundmass. A cathode-luminescence image on the right highlights numerous, trace-element rich, apatite microlites. 


\section{${ }^{40} \mathrm{Ar} /{ }^{39} \mathrm{Ar}$ Age Dating of Littlefield Rhyolites}

Single crystal ${ }^{40} \mathrm{Ar} /{ }^{39} \mathrm{Ar}$ age dates for 2 samples of upper Littlefield Rhyolite, 3 samples of lower Littlefield Rhyolite, a sample of rhyolite of Bully Creek Canyon, and a sample of rhyolite of Cottonwood Mountain, were performed at the New Mexico Geochronology Research Laboratory under the supervision of William McIntosh (Table 3). The resulting age determinations are relative to Fish Canyon Tuff (FC-1) sanidine monitors (28.201 Ma).

Table 9: Single crystal ${ }^{40} \mathrm{Ar} /{ }^{39} \mathrm{Ar}$ dates for the upper Littlefield Rhyolite, lower Littlefield Rhyolite, rhyolite of Bully Creek Canyon, and rhyolite of Cottonwood Mountain. See the appendix for ${ }^{40} \mathrm{Ar} /{ }^{39} \mathrm{Ar}$ sample locations and detailed results of ${ }^{40} \mathrm{Ar} /{ }^{39} \mathrm{Ar}$ sample analyses. Two separate analyses of sample BW-13-02 were performed and both produced questionable ages and unacceptable errors. *denotes repeat analysis.

\begin{tabular}{|c|c|c|c|c|c|c|}
\hline Unit & Sample ID & Method & Age (Ma) & Error $( \pm 2 \sigma)$ & $\mathbf{n}$ & MSWD \\
\hline upper Littlefield Rhyolite & BW-14-40 & ${ }^{40} \mathrm{Ar} /{ }^{39} \mathrm{Ar}$ & 16.01 & \pm 0.06 & 12 & 2.8 \\
\hline upper Littlefield Rhyolite & BW-14-67 & ${ }^{40} \mathrm{Ar} /{ }^{39} \mathrm{Ar}$ & 16.05 & \pm 0.04 & 11 & 2.1 \\
\hline lower Littlefield Rhyolite & BW-14-29a & ${ }^{40} \mathrm{Ar} /{ }^{39} \mathrm{Ar}$ & 16.12 & \pm 0.04 & 11 & 0.7 \\
\hline lower Littlefield Rhyolite & BW-14-19 & ${ }^{40} \mathrm{Ar} /{ }^{39} \mathrm{Ar}$ & 16.16 & \pm 0.10 & 12 & 3.9 \\
\hline lower Littlefield Rhyolite & BW-13-02 & ${ }^{40} \mathrm{Ar} /{ }^{39} \mathrm{Ar}$ & 16.3 & \pm 0.30 & 6 & 0.04 \\
\hline lower Littlefield Rhyolite & BW-13-02* & ${ }^{40} \mathrm{Ar} /{ }^{39} \mathrm{Ar}$ & 15.9 & \pm 0.37 & 7 & 2.48 \\
\hline $\begin{array}{c}\text { rhyolite of Bully Creek } \\
\text { Canyon }\end{array}$ & EJ-12-17 & ${ }^{40} \mathrm{Ar} /{ }^{39} \mathrm{Ar}$ & 16.12 & \pm 0.07 & 12 & 4.1 \\
\hline rhyolite of Cottonwood Mtn. & MS-12-31 & ${ }^{40} \mathrm{Ar} /{ }^{39} \mathrm{Ar}$ & 16.20 & \pm 0.08 & 10 & 3.7 \\
\hline
\end{tabular}


Age dates of the upper and lower Littlefield Rhyolite constrain the timing of eruptions of Hunter Creek Basalt, given their relative stratigraphic positions observed in the Malheur River Gorge area (Figure 45).

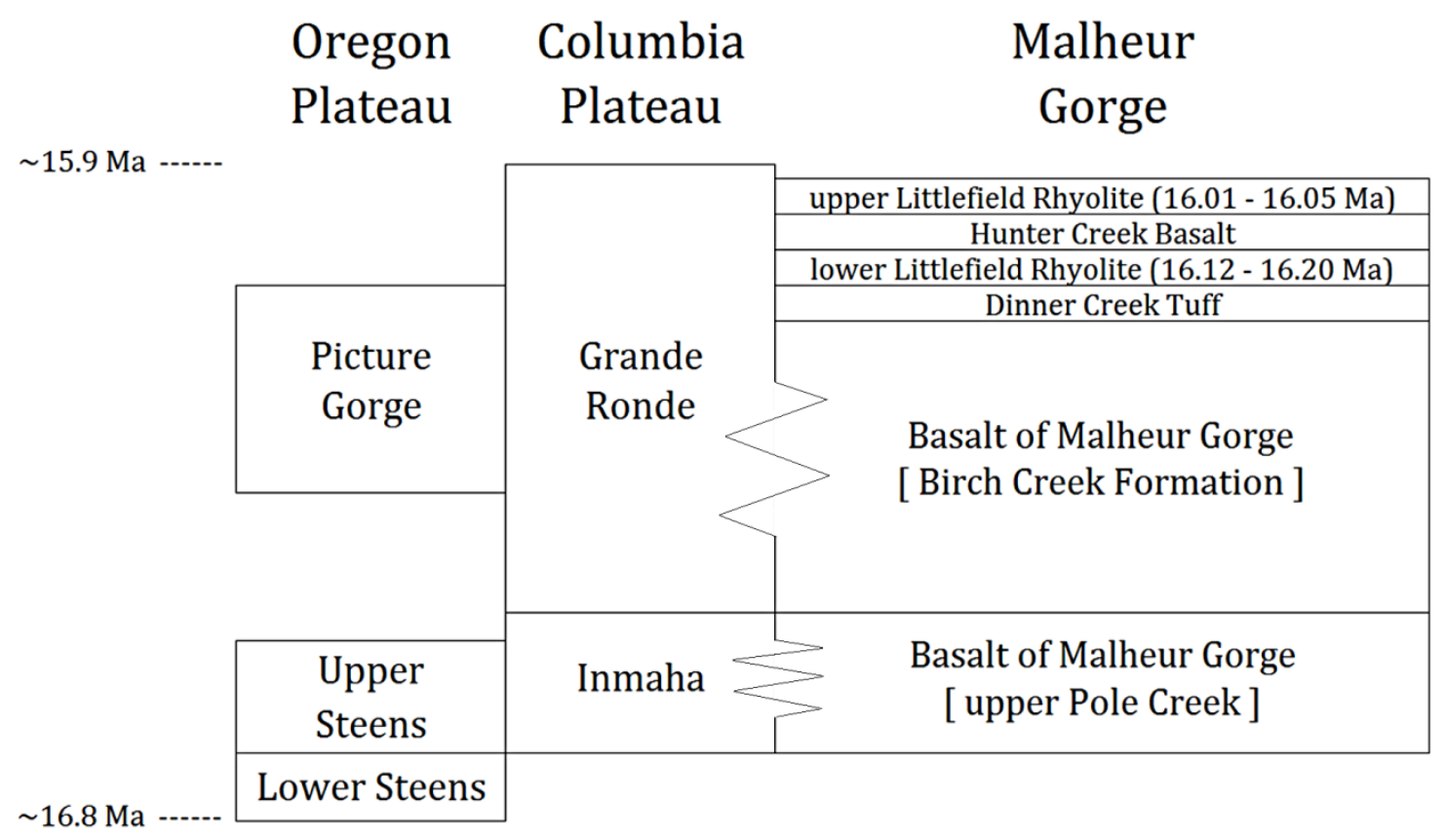

Figure 45: Correlations between main phase Columbia River Basalt Group lavas and the stratigraphy exposed in the Malheur River Gorge. Modified figure based on Wolff et al. (2008).

\section{Mafic Units}

\section{Hunter Creek Basalt (tholeiitic basaltic andesite)}

The Hunter Creek Basalt is a local, late-stage eruption of Grande Ronde magma, which is compositionally similar to Wapshilla Ridge Member lavas (Reidel \& Tolan, 2013). Outcrops typically consist of hackney-jointed, black or dark-grey, aphanitic, tholeiitic basaltic andesite ( $\sim 55$ wt. $\left.\% \mathrm{SiO}_{2}\right)$, which commonly weathers to form steep, talus dominated slopes that obscure outcroppings. Commonly a single lava flow is observed throughout its relatively widespread distribution within the 
Malheur River Gorge and beyond. However, there are four distinct stratigraphic units observed in the Namorf transect area along the eastern extent of the Malheur River Gorge. There, individual stratigraphic units consist of a glassy, agglutinated spatter deposit, along with three lava flows. Lava flows have preserved vesicular upper flow sections. Vesicles sometimes contain amygdules, usually consisting of light-colored zeolites. The lowest lava flow directly overlies the lower Littlefield Rhyolite, and is separated from the upper two lavas by overlying stratigraphic units. The shared contact between the upper two lava flows is marked by a baked-zone.

Hunter Creek lavas have aphanitic textures composed of groundmass feldspar, magnetite, clinopyroxene, and interstitial glass (Figure 46, Figure 47, Figure 48). Phenocrysts are rare, but if present consist of plagioclase and clinopyroxene (Figure 46, Figure 48). Though all three lavas have aphanitic textures, the lowest lava flow appears more course-grained than the upper two lavas. 

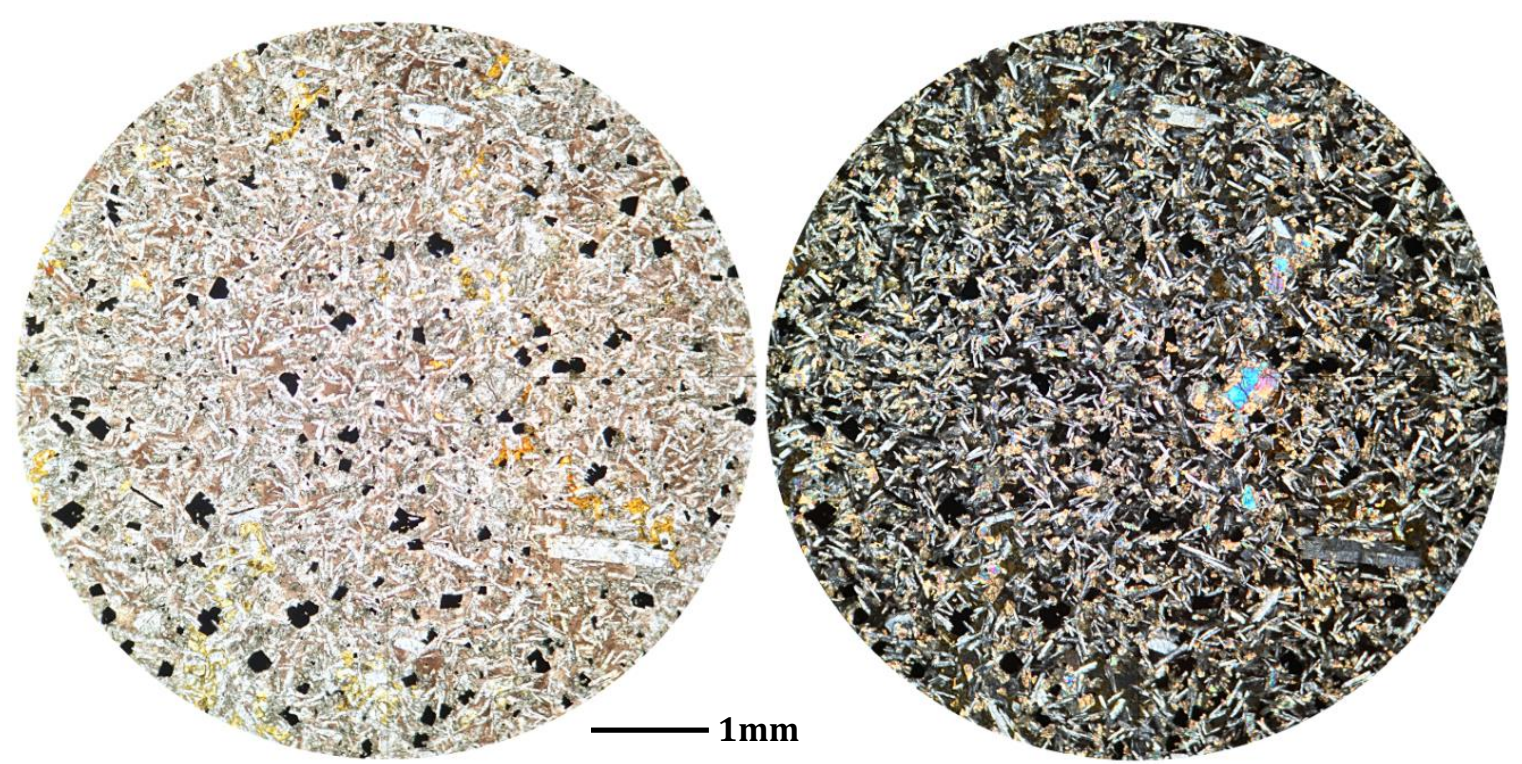

Figure 46: Photomicrographic image of the lower Hunter Creek Basalt lava at the primary transect within the Malheur River Gorge.

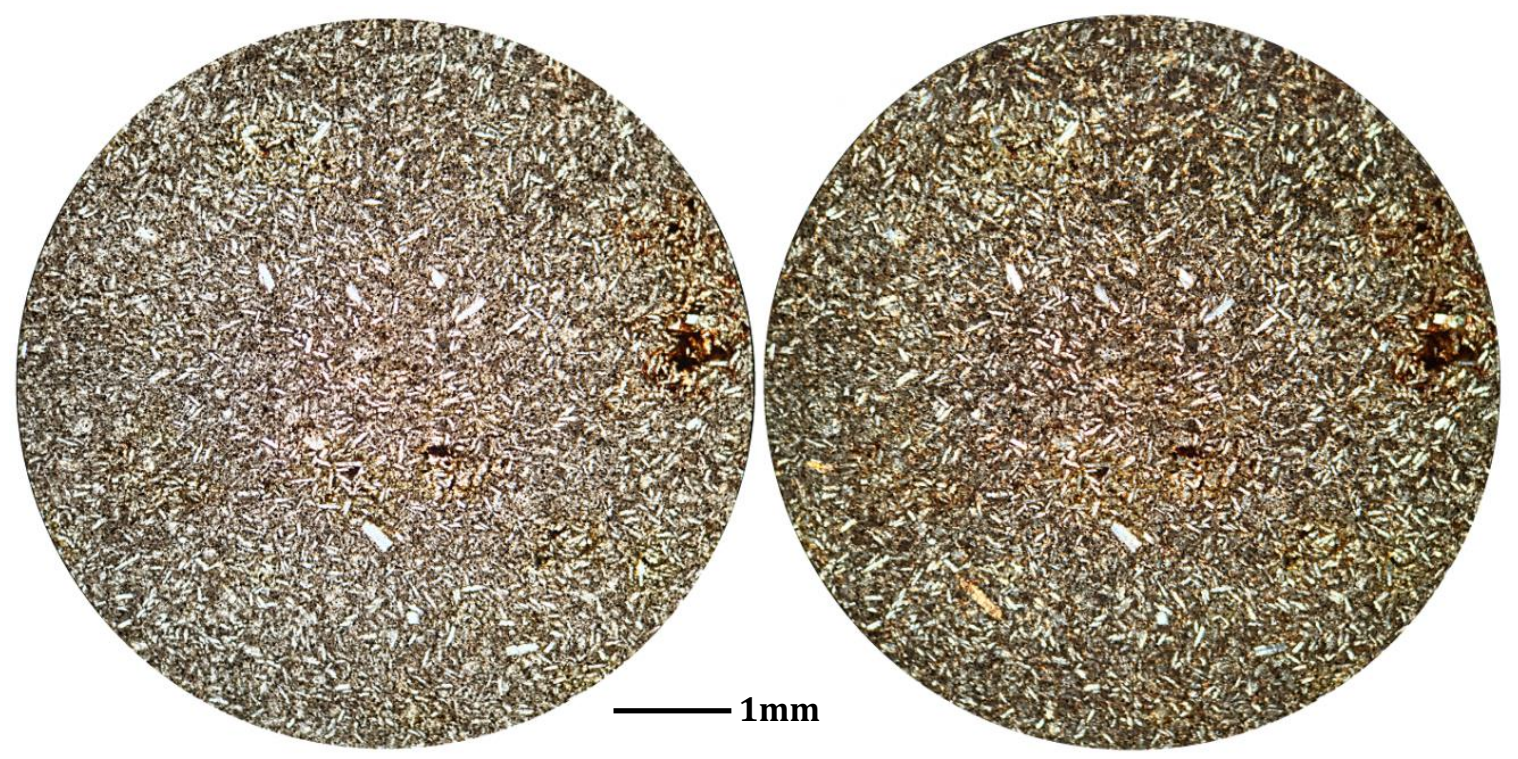

Figure 47: Photomicrographic image of the middle Hunter Creek Basalt lava at the primary transect within the Malheur River Gorge. 

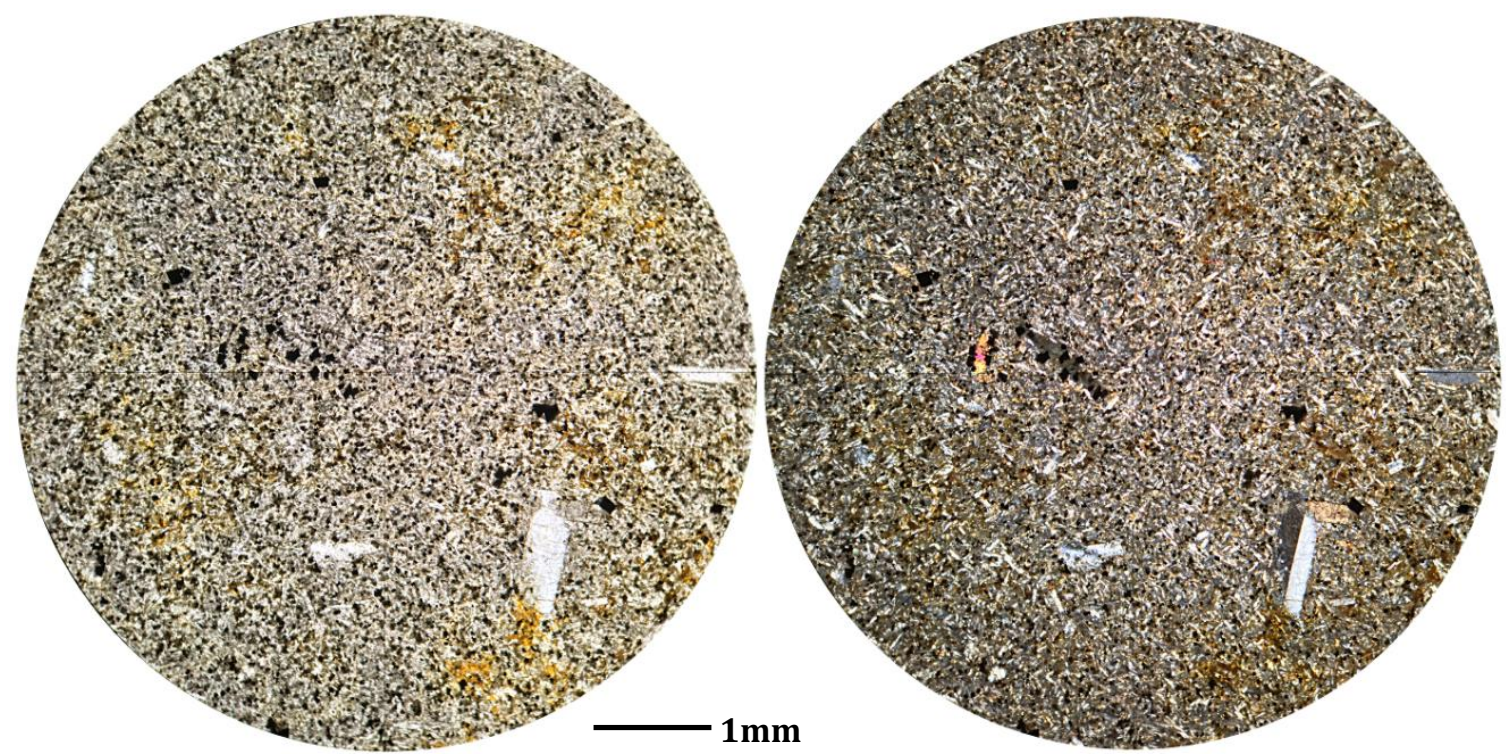

Figure 48: Photomicrographic image of the upper Hunter Creek Basalt lava at the primary transect within the Malheur River Gorge.

The Hunter Creek Basalt agglutinated spatter deposit observed within the Malheur River Gorge consists of densely welded, glassy basaltic andesite, with scattered, sparsely cumulophyric microphenocrysts of feldspar and clinopyroxene. Basaltic andesite glass appears nearly opaque when viewed in plain-polarized light (Figure 49). 


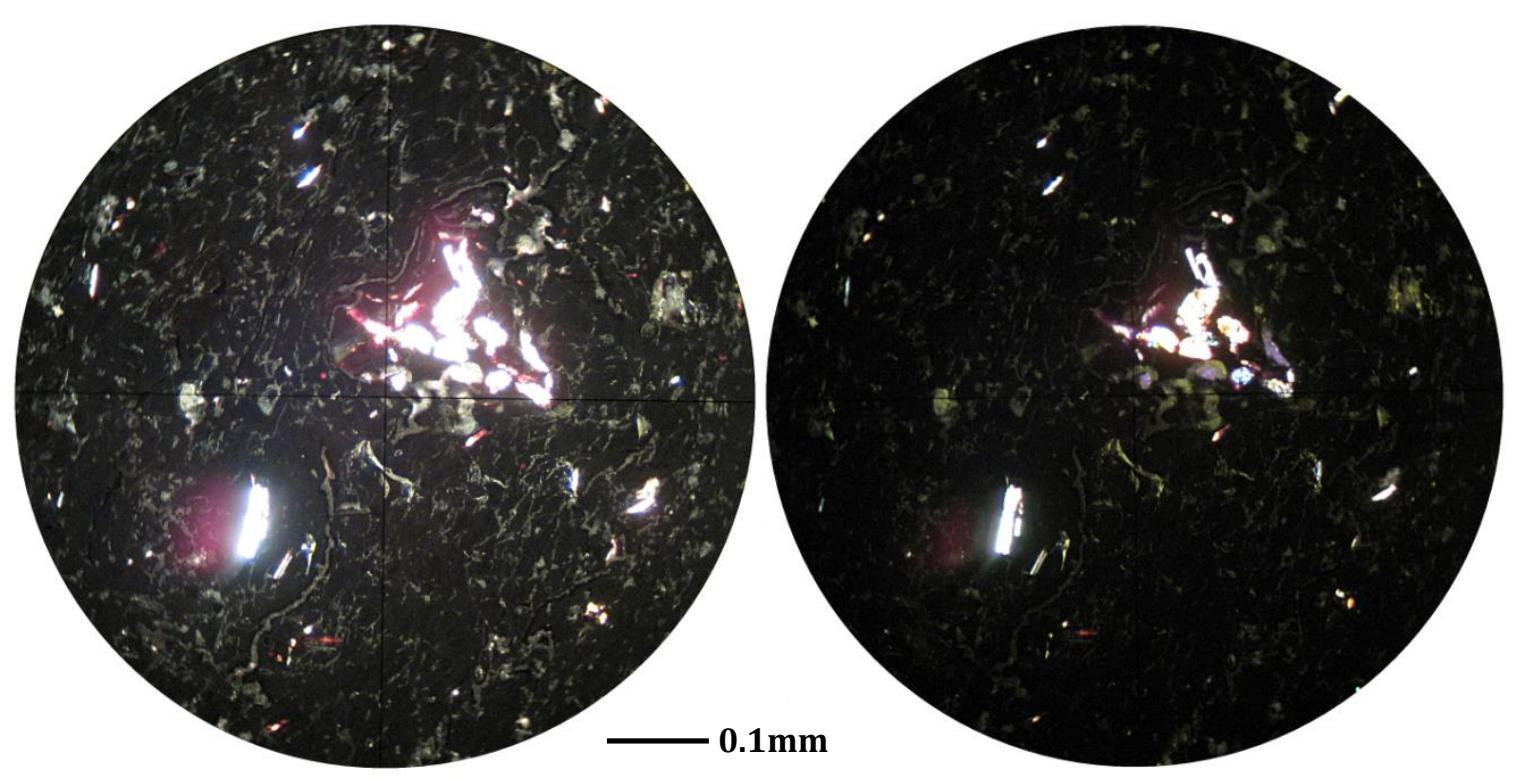

Figure 49: Photomicrographic image of agglutinated spatter of Hunter Creek Basalt. The groundmass is composed of welded shards of basaltic andesite glass, which appears opaque in both plain and cross polarized light. Scattered, sparsely cumulophyric microphenocrysts of feldspar and clinopyroxene are visible.

Major and trace element compositions of Hunter Creek lavas appear to be relatively constrained within a limited range of compositions throughout the distribution of the unit, with the exception of $\mathrm{Ba}$, which can range between 640 - 1294 ppm (Table 10, Figure 50).

Table 10: The average, minimum, and maximum wt.\% major element composition of 12 samples of Hunter Creek Basalt, including trace element concentrations of Ba (ppm).

\begin{tabular}{ccccccccccc|c}
\hline \hline & $\mathrm{SiO}_{2}$ & $\mathrm{TiO}_{2}$ & $\mathrm{Al}_{2} \mathbf{O}_{3}$ & $\mathrm{FeO}^{*}$ & $\mathrm{MnO}$ & $\mathrm{MgO}$ & $\mathrm{CaO}$ & $\mathrm{Na}_{2} \mathbf{O}$ & $\mathrm{K}_{2} \mathbf{O}$ & $\mathbf{P}_{2} \mathbf{O}_{5}$ & $\begin{array}{c}\mathbf{B a} \\
\mathbf{p p m}\end{array}$ \\
\hline Max & 56.73 & 2.39 & 13.90 & 13.89 & 0.22 & 3.61 & 7.27 & 3.53 & 2.19 & 0.58 & 1294 \\
Mean & 55.65 & 2.34 & 13.58 & 12.74 & 0.20 & 3.22 & 6.87 & 3.06 & 1.86 & 0.47 & 804 \\
Min & 54.21 & 2.21 & 13.44 & 11.34 & 0.17 & 2.77 & 6.19 & 2.71 & 0.90 & 0.45 & 653 \\
\hline
\end{tabular}




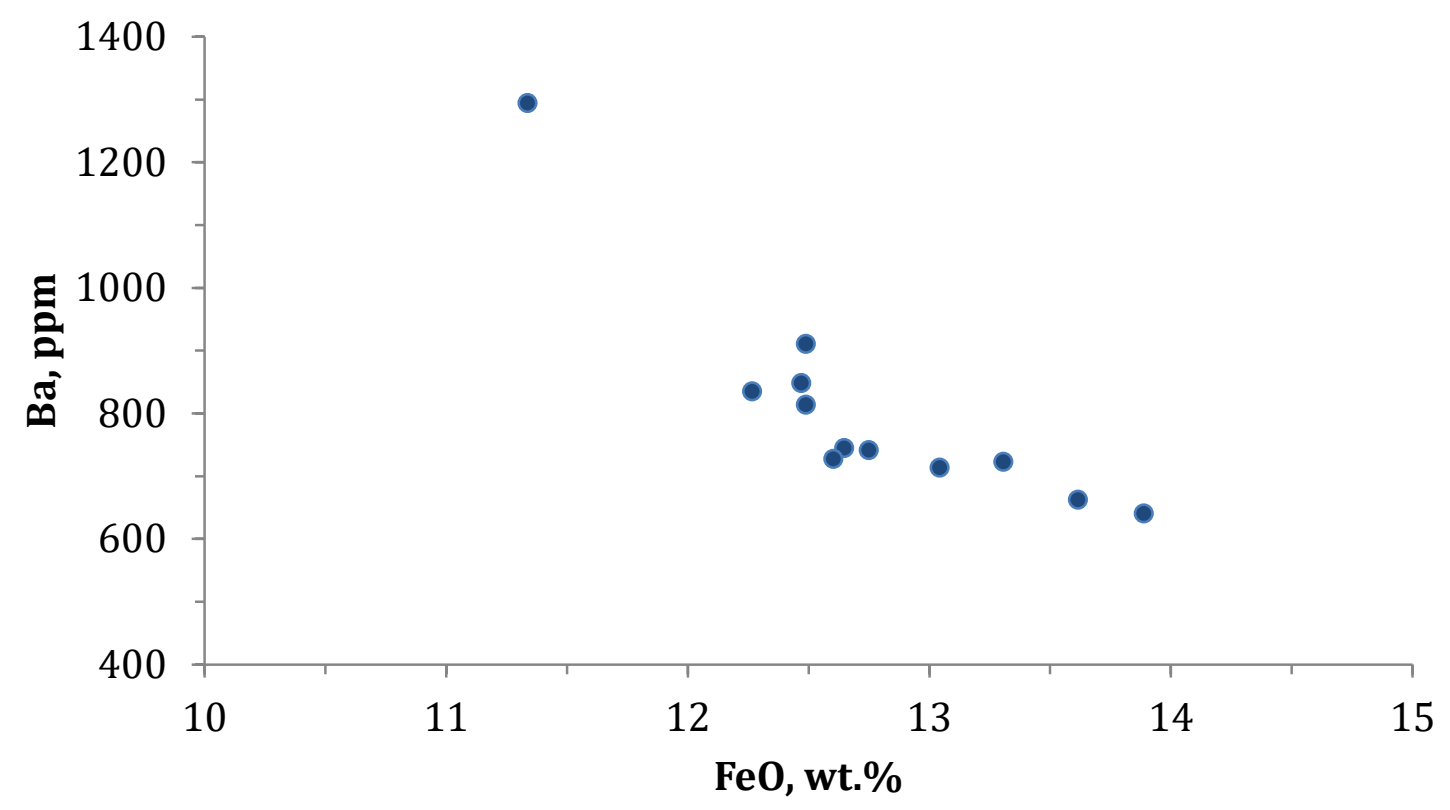

Figure 50: Plot of Ba (ppm) versus FeO (wt.\%) for Hunter Creek Basalt samples.

\section{Icelandite of Alder Creek Canyon}

The icelandite of Alder Creek Canyon $\left(\sim 62 \mathrm{wt.} \% \mathrm{SiO}_{2}\right)$ is stratigraphically equivalent to the Hunter Creek Basalt, where it is observed in the southern transect in Alder Creek Canyon. Though lithologically similar and petrogenetically related to more commonly observed Hunter Creek lavas ( $\sim 55$ wt.\% $\left.\mathrm{SiO}_{2}\right)$, the icelandite lava is markedly platy-jointed and is geochemically distinct. Relative to commonly observed Hunter Creek Basalt, which is widespread in the Malheur River Gorge and in areas further north, the icelandite has seemingly uniformly higher concentrations of most trace elements, with the exception of $\mathrm{Sr}, \mathrm{P}$, and $\mathrm{Ti}$, which are relatively lower (Figure 51). 


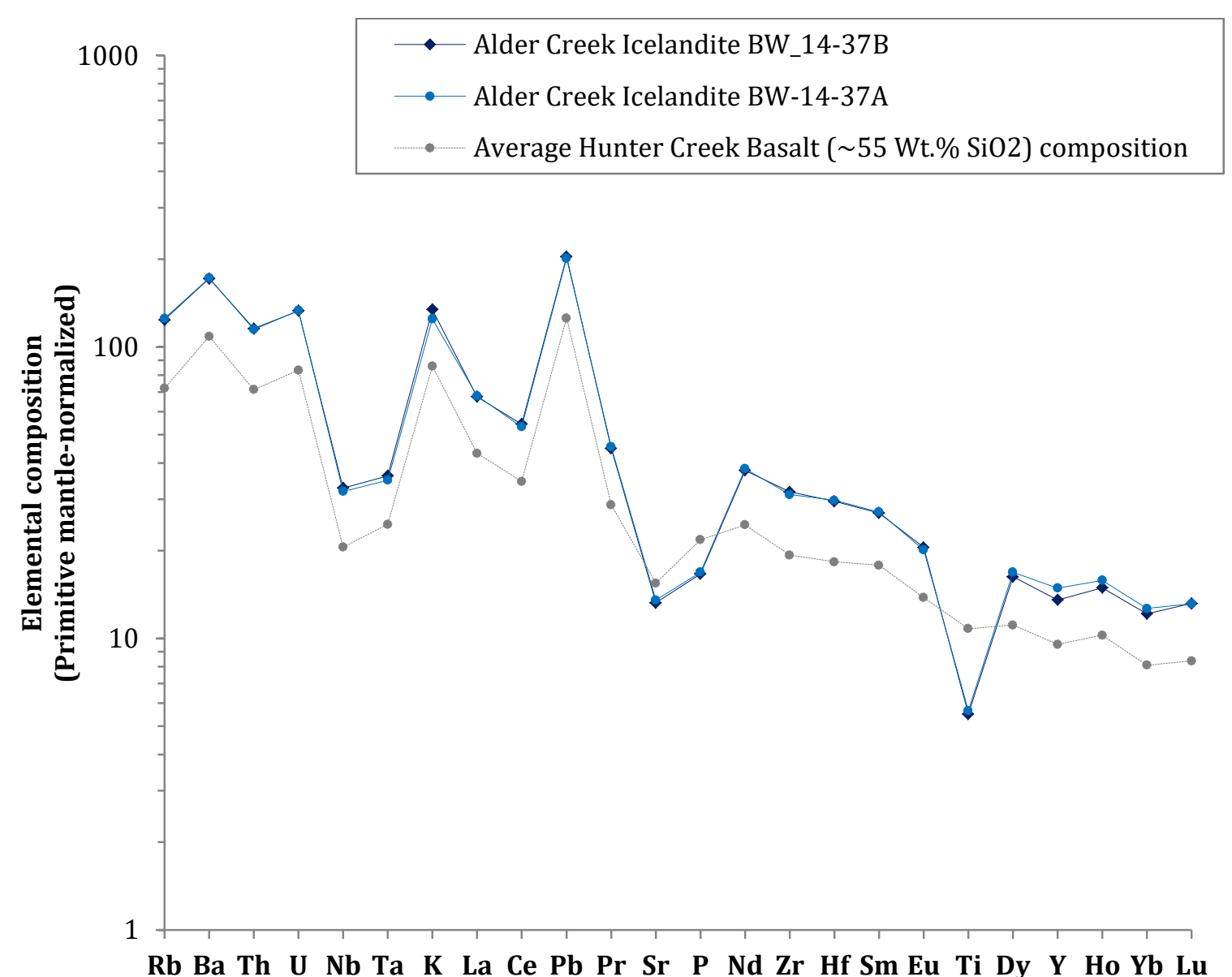

Figure 51: Primitive mantle-normalized elemental composition of two samples of icelandite of Alder Creek Canyon lavas ( $\left.\sim 63 \mathrm{wt} . \% \mathrm{SiO}_{2}\right)$, compared to the average composition of commonly observed Hunter Creek Basalt lavas $\left(\sim 55 \mathrm{wt} . \% \mathrm{SiO}_{2}\right)$. With the exception of $\mathrm{Ba}$, the range of compositions of Hunter Creek Basalt samples is sufficiently narrow, and the average composition is shown here for simplicity. The plot suggests that icelandite and Hunter Creek compositions may be petrogenetically related, with the icelandite showing similar increases or decreases in trace element concentrations relative to Hunter Creek Basalt. Nevertheless, icelandite of Alder Creek Canyon and Hunter Creek Basalt lavas are geochemically distinct units.

The icelandite of Alder Creek Canyon is petrographically similar to typical Hunter Creek Basalt lavas, having aphanitic texture containing groundmass feldspar, magnetite, clinopyroxene, and interstitial glass. In contrast, the icelandite of Alder Creek Canyon contains rare, but relatively large, phenocrysts of tabular feldspars (Figure 52). 

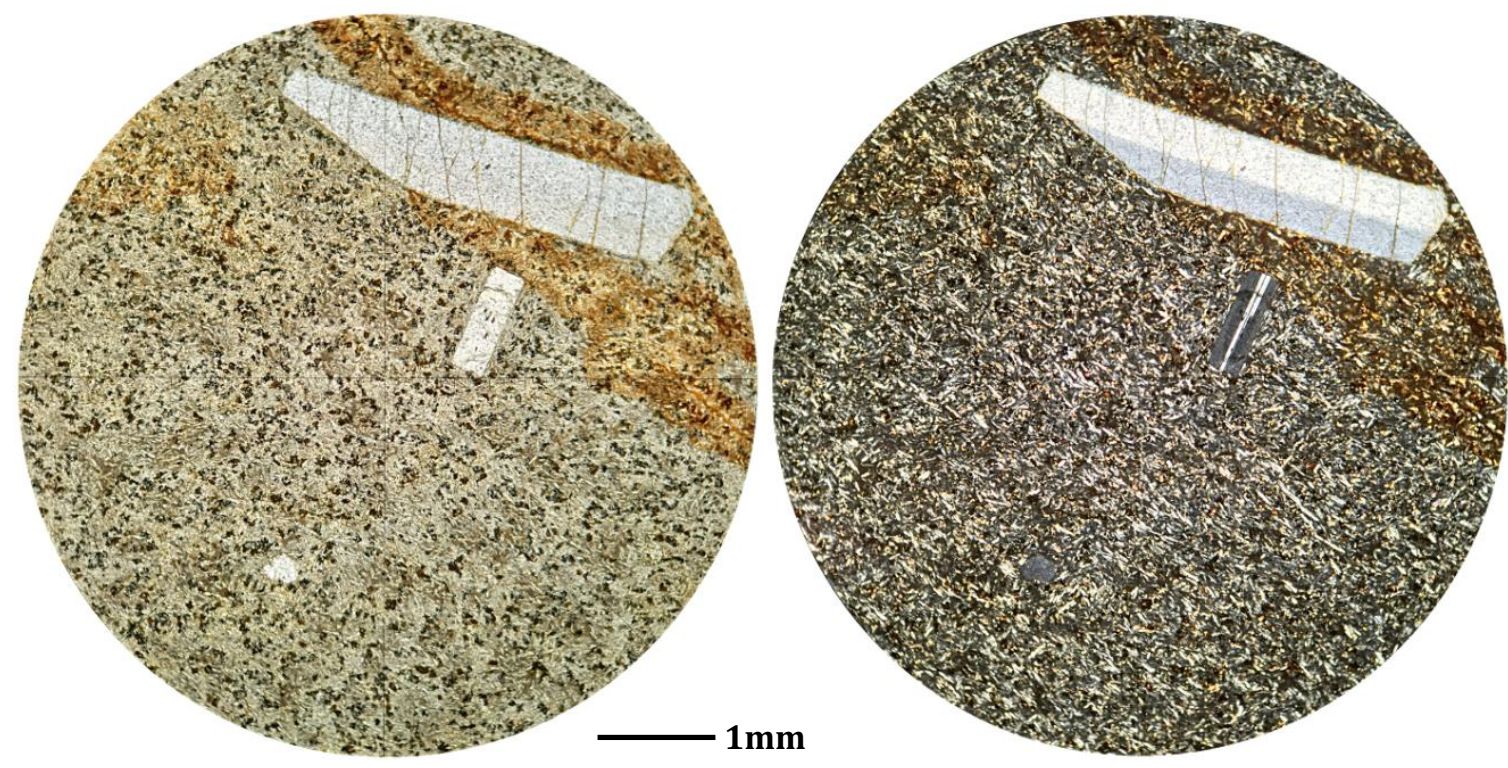

Figure 52: Photomicrographic image of Icelandite of Alder Creek Canyon, showing aphanitic texture and rare phenocrysts of tabular feldspar.

\section{Tuffaceous Units \\ Dacitic tuff}

A thin $(\sim 40 \mathrm{~cm})$, but widely distributed, light-brown or orange-red colored, porous, moderately-welded, dacitic tuff directly underlies the upper Littlefield Rhyolite. This unit is distinctly orange-red in color within Alder Creek Canyon. Further north, in the Malheur River Gorge, the dacitic tuff was impacted by overriding basal breccia of the upper Littlefield Rhyolite, where some of the lighter-colored, tuffaceous material appears to have been incorporated into the matrix of the overlying basal breccia during emplacement of the upper Littlefield Rhyolite.

The dacitic welded tuff underlying the upper Littlefield Rhyolite is a porous, moderately welded, fine-grained tuff. Textures are variable, but commonly contain lithic fragments and lapilli in a fine-grained ash matrix (Figure 53). 


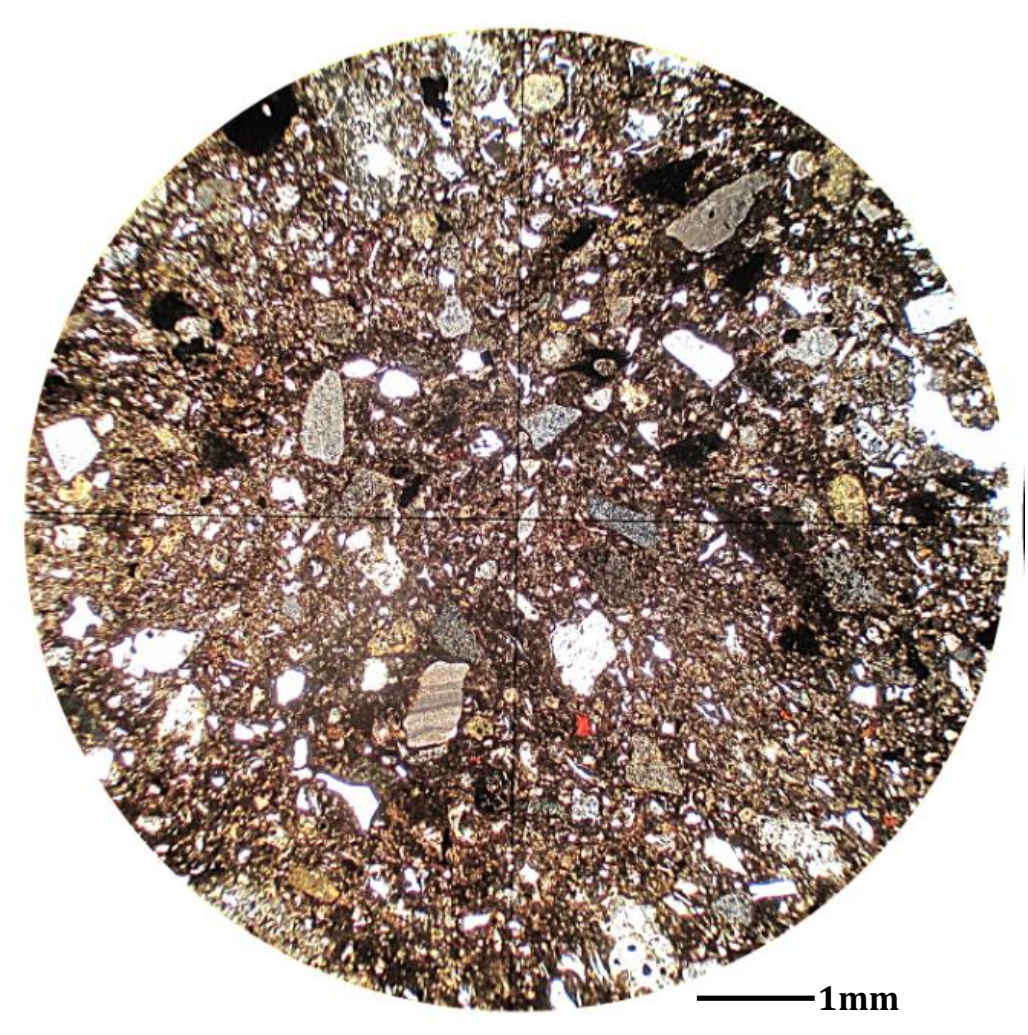

Figure 53: Photomicrographic image of dacitic welded tuff that underlies the upper Littlefield Rhyolite at the primary transect at Namorf. The unit is also observed underlying the upper Littlefield Rhyolite in Alder Creek Canyon.

\section{Epiclastic tuff}

In the field, the $\sim 0.5$ meter thick epiclastic tuff commonly appears much like a moderately- to strongly-lithified tuffaceous sandstone. Despite its sedimentary appearance in the field, the unit petrographically appears to be a nearly primary pyroclastic unit, as it does not appear to contain much, if any, fluvially derived material. Reworking of tuffaceous material is not apparent when viewed in thin section, but there is evidence that post-deposition silicification and alteration occurred at some outcrops. Rare, well exposed outcrops exhibit clear primary 
pyroclastic characteristics of a lapilli tuff, with lapilli-sized pyroclasts in a finegrained matrix.

The epiclastic tuff may be stratigraphically equivalent to tuffaceous sandstone (Ts) noted by Evans and Binger (1998) further north, where it overlies the Hunter Creek Basalt and underlies the upper Littlefield Rhyolite (Evan and Binger, 1998). This suggests that the lower Hunter Creek lava observed at the primary transect site is stratigraphically equivalent to the widespread Hunter Creek lava also observed in the north, and that the middle and upper Hunter Creek lavas observed at Namorf are localized flows. At Namorf, this unit is stratigraphically equivalent to tuffaceous siltstone (Tlrt) of Ferns and O'Brien (1992).

When viewed in thin section, primary pyroclastic features of the unit appear to be angular, fragmented, subhedral sanidine ( $\mathrm{Or}_{47-49}, \mathrm{An}_{1.1-1.2}, \mathrm{Ab}_{50-52}$ ) (Figure 54, Table 11) and quartz, which are embedded in a matrix of silicified lapilli and ash (Figure 55). The sanidine and quartz strongly resemble each other when viewed under cross-polarized light, making a reliable determination of their relative abundances uncertain. 


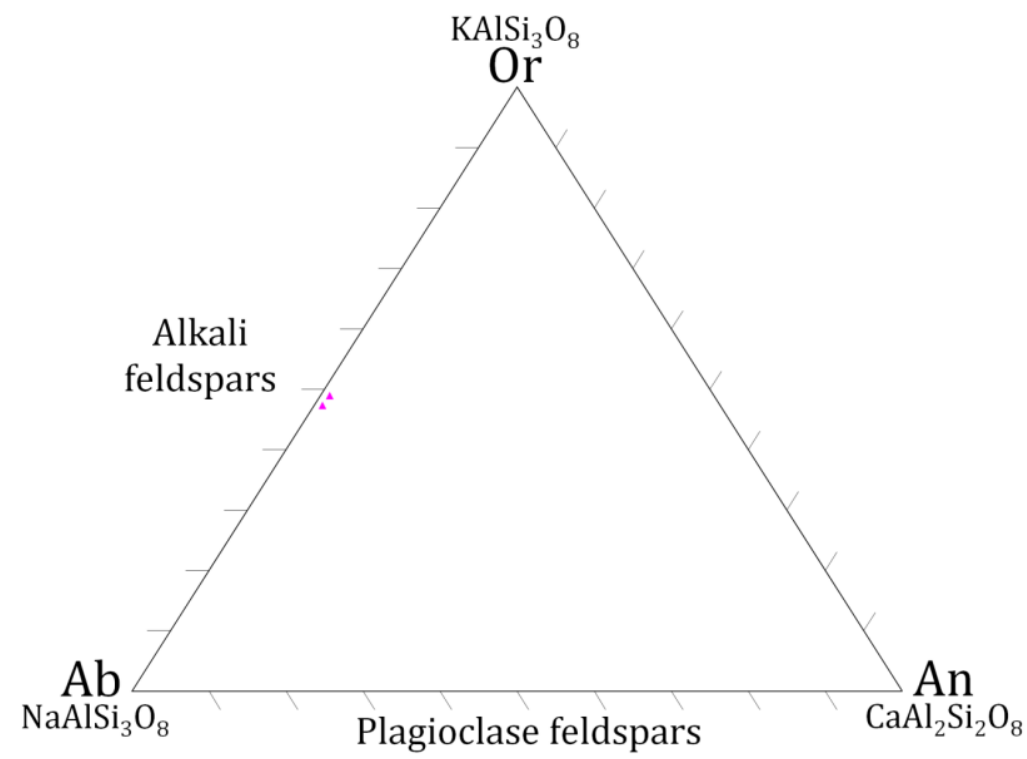

Figure 54: Ternary diagram shows the average feldspar end-member composition of the epiclastic tuff.

Table 11: The average, minimum, and maximum calculated end-member compositions from electron Microprobe (EMP) analyses of epiclastic tuff sanidine phenocryst phases. Epiclastic tuff sample number: BW-14-12.

\begin{tabular}{cccc}
\hline \hline BW-14-12 & \%Or & \%An & \%Ab \\
\hline Max & 48.96 & 1.19 & 51.60 \\
Mean & 48.15 & 1.12 & 50.73 \\
Min & 47.34 & 1.06 & 49.85 \\
\hline
\end{tabular}
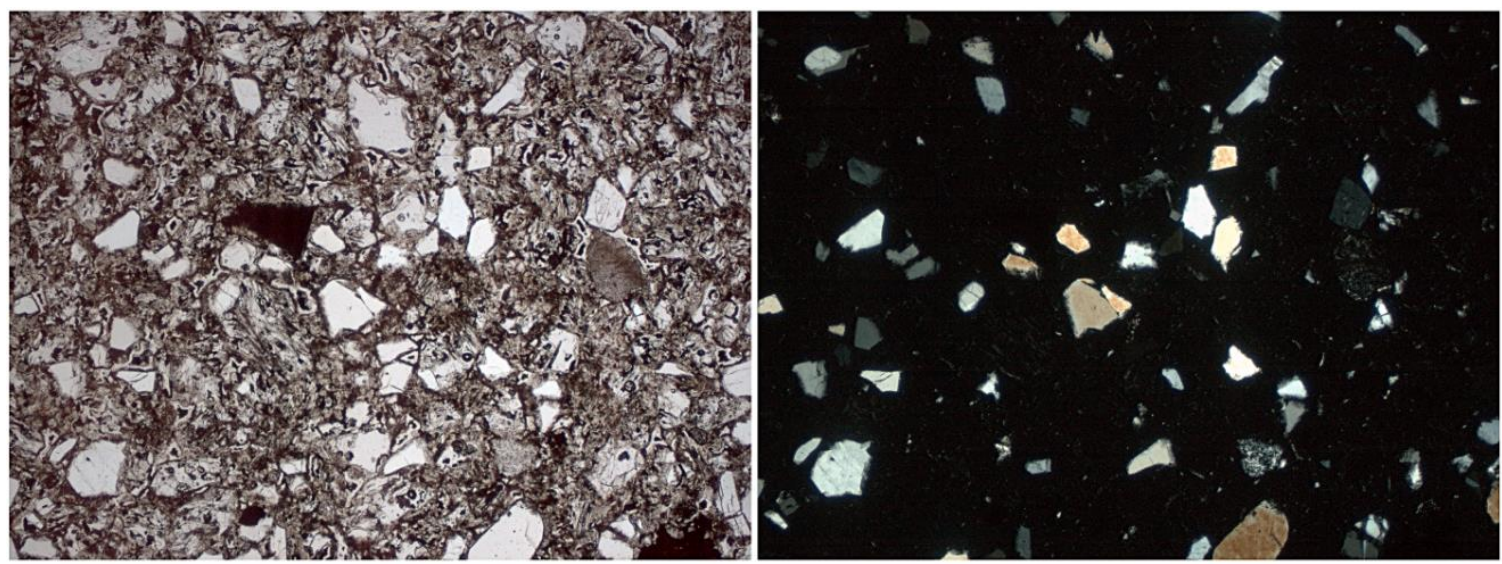

Figure 55: Photomicrographic image of the epiclastic tuff, showing sandine and quartz phenocrysts in a eutaxic matix. Scattered, fractured, angular grains of sanidine and quartz strongly resemble each other when viewed under cross-polarized light, making a reliable determination of their relative abundances uncertain. 
The trace element composition of the epiclastic tuff shows many similarities with that of Dinner Creek Tuff eruptive units, particularly with the unit 1 ignimbrite of Streck et al. (2015), with the notable exception of Ba and Eu concentrations, which are significantly lower in the epiclastic tuff (Figure 56, Figure 57). Fractionation of feldspar might be responsible for the decrease in $\mathrm{Ba}$ and $\mathrm{Eu}$ concentrations observed in the epiclastic tuff, but this cannot explain fractionation from a Dinner Creek Tuff magma, as there would be reductions in the concentrations of other elements.

Petrographic differences between the epiclastic tuff and Dinner Creek Tuff units are significant. The epiclastic tuff is relatively crystal rich, containing quartz and sanidine. The Dinner Creek Tuff is relatively crystal-poor, contains no quartz crystals, and contains anorthoclase to low An plagioclase phenocryst phases (Streck et al., 2015). Nevertheless, the geochemical similarities are intriguing, and raise questions about the general similarities of many mid-Miocene rhyolite compositions and the potential sources of crustal contamination. 


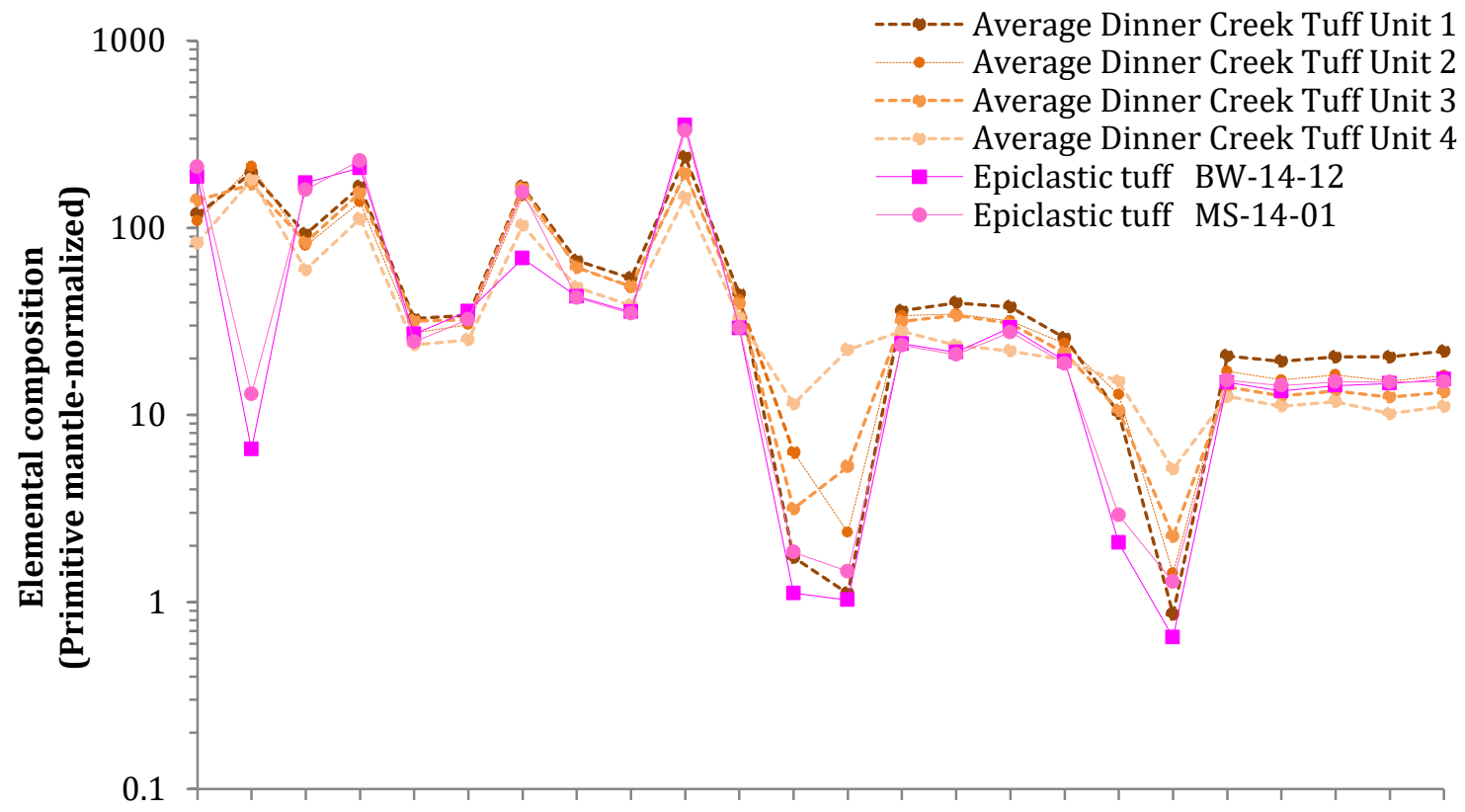

Rb Ba Th U Nb Ta K La Ce Pb Pr Sr P Nd Zr Hf Sm Eu Ti Dy Y Ho Yb Lu

Figure 56: Elemental composition of two samples of the epiclastic tuff that overlies the Hunter Creek Basalt agglutinate at Namorf, compared with the average compositions of the four Dinner Creek Tuff (DIT) eruptive units identified by Streck et al. (2015). DIT geochemical data is from Streck et al. (2015). The epiclastic tuff has significantly less Ba and Eu compared to the Dinner Creek ignimbrites.

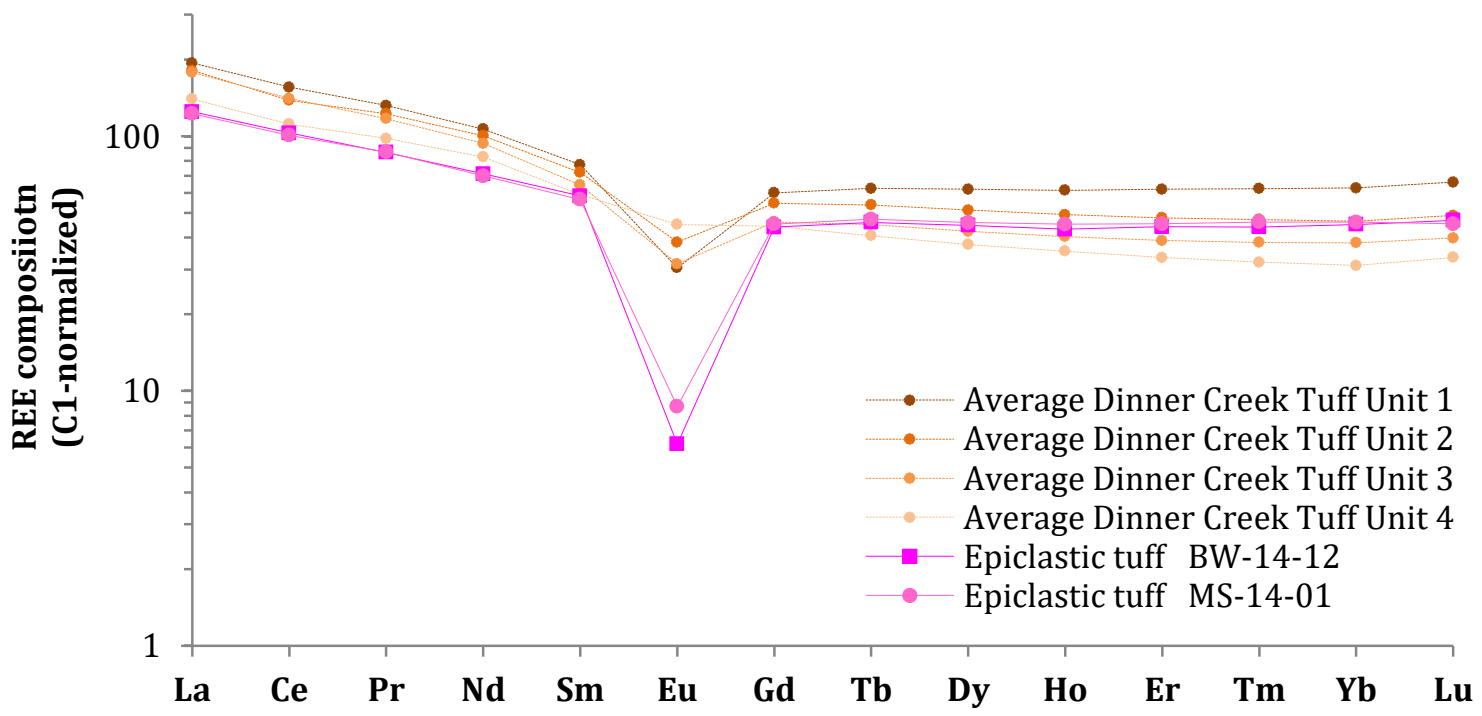

Figure 57: REE compositions of two samples of the epiclastic tuff that overlies the Hunter Creek Basalt agglutinate at Namorf, compared with the average compositions of the four Dinner Creek Tuff eruptive units identified by Streck et al. (2015). Though the overall REE compositions are similar, the epiclastic tuff has significantly less europium. Dinner Creek Tuff geochemical data is from Streck et al. (2015). 


\section{Dinner Creek Tuff}

The cooling unit 1 of the Dinner Creek Tuff is the earliest rhyolite to be emplaced within the Malheur River Gorge, where the unit forms a distinct stratigraphic marker bed. The Dinner Creek Tuff overlies the basalt of Malheur Gorge, and marks the initiation of bimodal volcanism that occurred within the greater Malheur River Gorge area. The earlier tholeiitic dominated stratigraphy emplaced within the Malheur River Gorge originated from distal vents associated with the Steens and Chief Joseph dike swarms, whereas the later bimodal volcanism was erupted from proximal vents.

The appearance of the Dinner Creek Tuff can be quite varied, but is commonly a light-grey to dark-brown, crystal-poor, lithic-rich, poorly-welded to densely-welded, rhyolitic ignimbrite. The Dinner Creek Tuff overlies the basalt of Malheur Gorge sequence of units, and underlies either the Hunter Creek Basalt, or the lower Littlefield Rhyolite, where present. In the eastern extent of the Malheur River Gorge, the unit forms a light-grey, porous, moderately-welded ash flow tuff, and displays yellowish weathered surfaces. Unit generally thickens towards the west, is darkgrey or dark-brown, and becomes increasingly moderately-welded to denselywelded. Further to the south, within Alder Creek Canyon, the unit forms a lightcolored, relatively thick but poorly-welded, pyroclastic deposit.

Dinner Creek Tuff sample BW-14-45 is stratigraphically and petrographically distinct from the commonly observed Dinner Creek Tuff at Namorf. Sample BW-14- 
45 was only observed as abundant platy-jointed talus that appears in a relatively confined area when hiking though the upper flow section of the lower Littlefield Rhyolite along the primary transect at Namorf. The source of the talus is currently unknown, but it is not from the unit that currently crops out within the stratigraphy at Namorf. What is currently known is that (1) the tuff is geochemically similar to Dinner Creek Tuff--unit 1 of Streck et al. (2015) (Figure 58, Figure 59), (2) the tuff is stratigraphically distinct from the commonly observed Dinner Creek Tuff cooling unit 1 that underlies the lower Littlefield Rhyolite at Namorf, (3) the tuff is petrographically distinct from the commonly observed Dinner Creek Tuff cooling unit 1 , as it contains few but ubiquitous clinopyroxene phenocrysts, and (4) the tuff was emplaced at some time after the emplacement of the lower Littlefield Rhyolite.

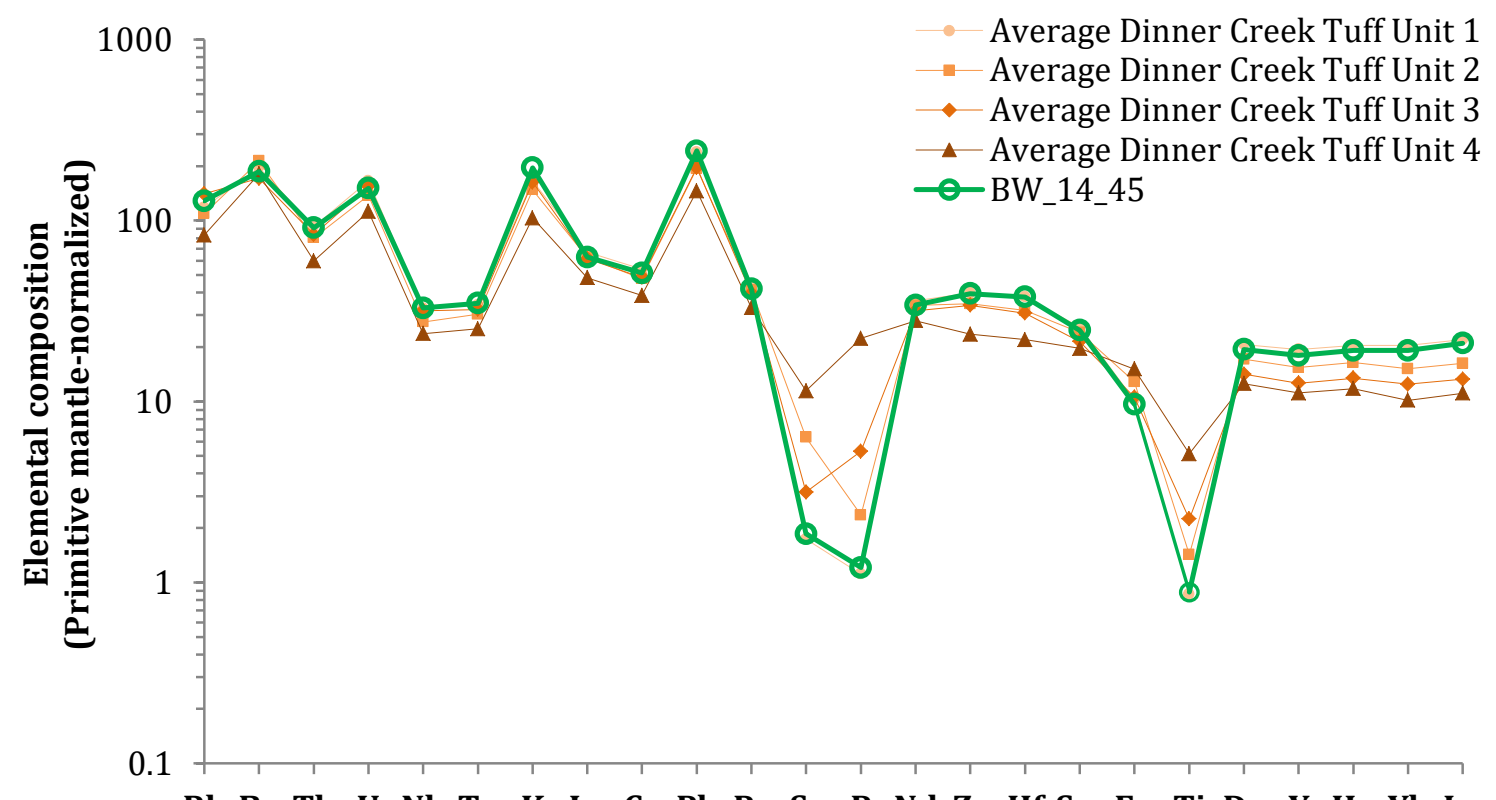

Rb Ba Th U Nb Ta K La Ce Pb Pr Sr P Nd Zr Hf Sm Eu Ti Dy Y Ho Yb Lu

Figure 58: Plot shows the average compositions of Dinner Creek Tuff units 1-4 of Streck et al. (2015), compared to Dinner Creek Tuff sample BW-14-45. Normalization values from Sun \& McDonough (1989). 


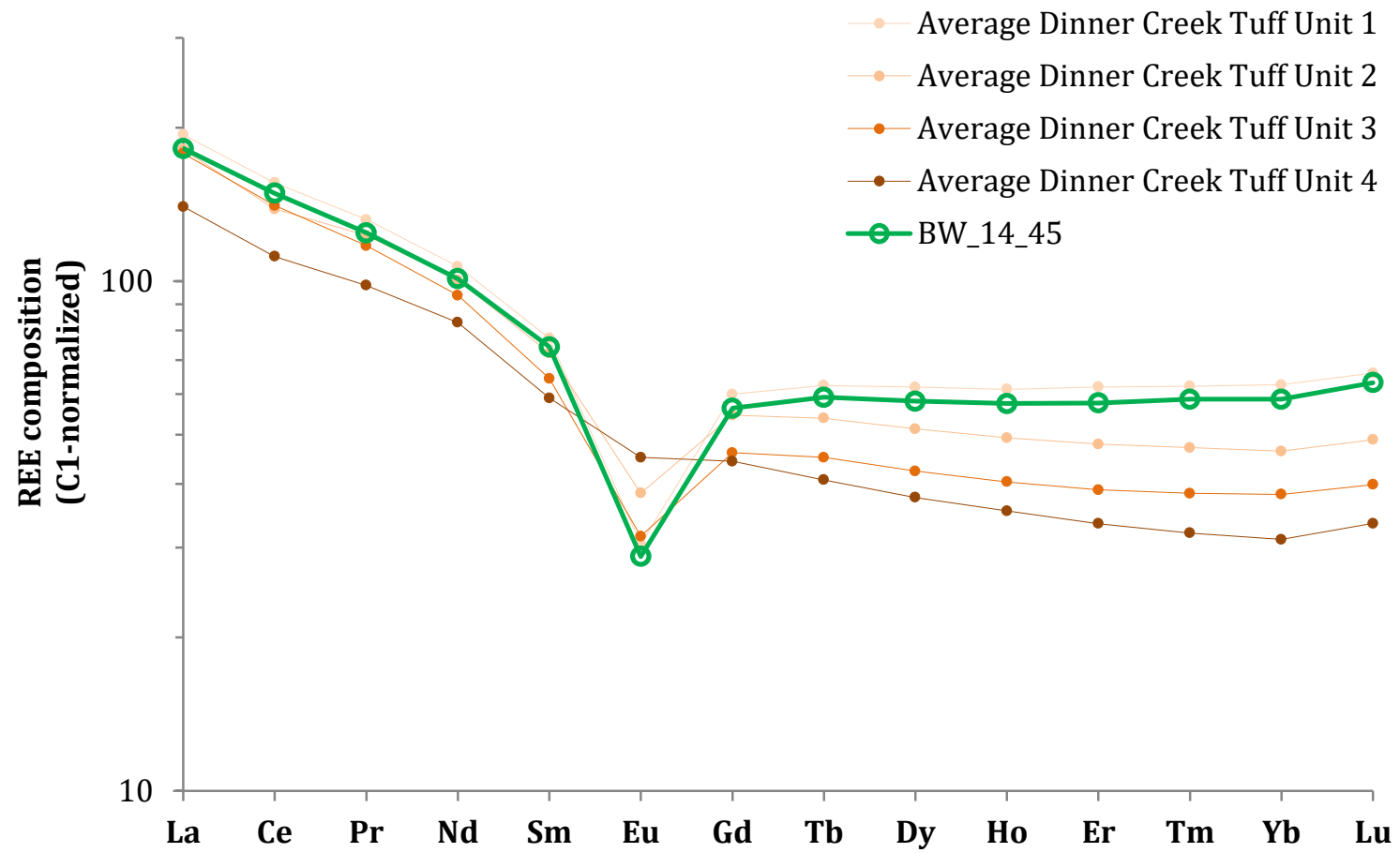

Figure 59: Plot shows the average REE compositions of Dinner Creek Tuff units 1-4 of Streck et al. (2015), compared to Dinner Creek Tuff sample BW-14-45. Normalization values from Sun \& McDonough (1989).

Though typically crystal poor, Dinner Creek Tuff sample BW-14-45 contains sparsely distributed augite (Wo41-43, Fs s1-52, En $_{7-17}$ ) (Figure 60, Table 12, Figure 62), which is rarely seen in Dinner Creek Tuff units, along with commonly observed plagioclase feldspar (Or8-12, An8-12, Ab80-81) phenocrysts (Figure 61; Table 13). 


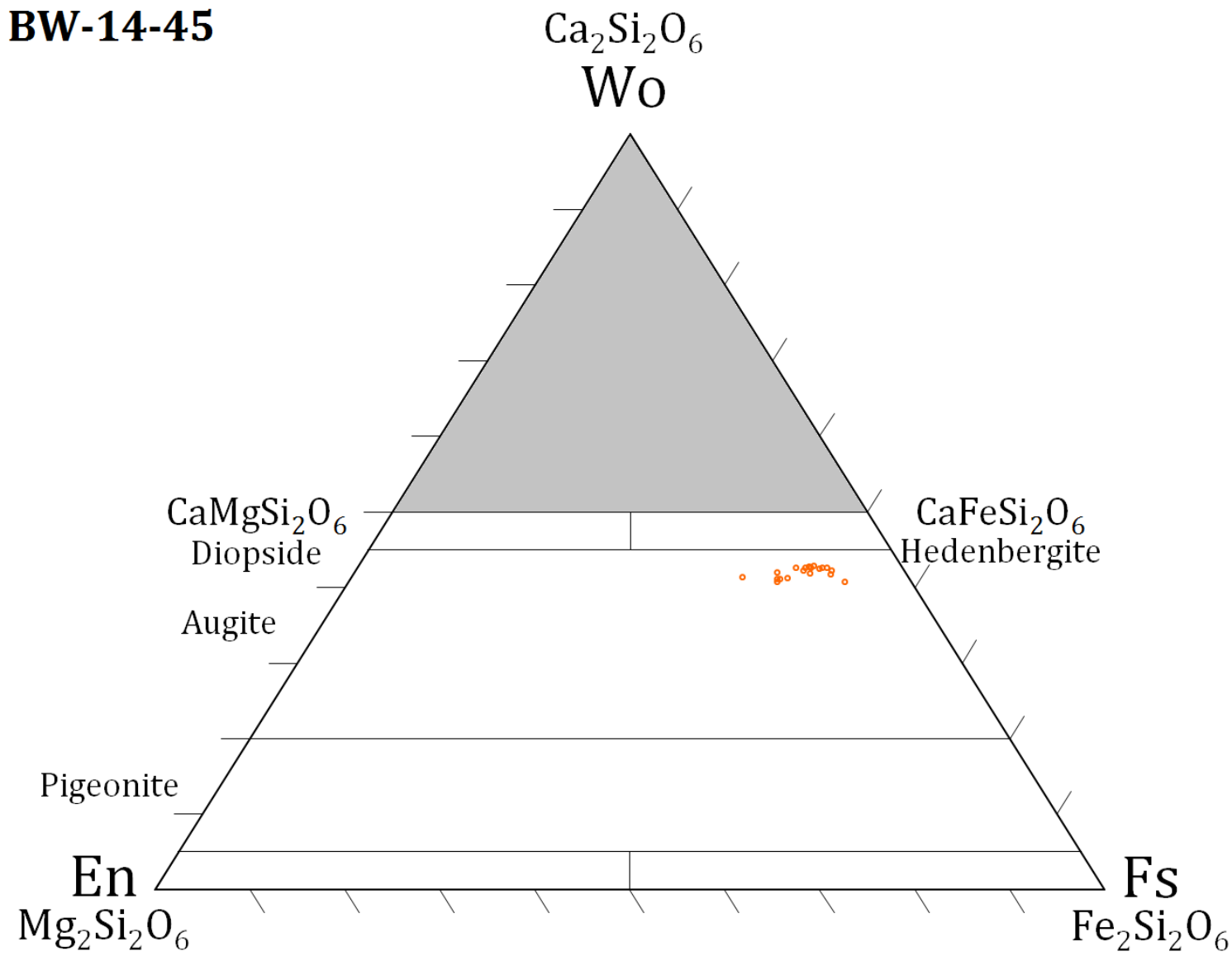

Figure 60: The average, minimum, and maximum calculated end-member compositions from electron Microprobe (EMP) analyses of Dinner Creek Tuff pyroxene phenocrysts. Dinner Creek Tuff sample BW-14-45 is petrographically and stratigraphically distinct from the formally recognized Dinner Creek Tuff unit that is mapped throughout the Malheur River Gorge.

Table 12: The average, minimum, and maximum calculated end-member compositions from electron Microprobe (EMP) analyses of Dinner Creek Tuff pyroxene phenocrysts.

\begin{tabular}{cccc}
\hline \hline BW-14-45 & \%Wo & \%Fs & \%En \\
\hline Max & 42.80 & 52.41 & 17.46 \\
Mean & 41.92 & 47.44 & 10.64 \\
Min & 40.64 & 41.26 & 6.93 \\
\hline
\end{tabular}




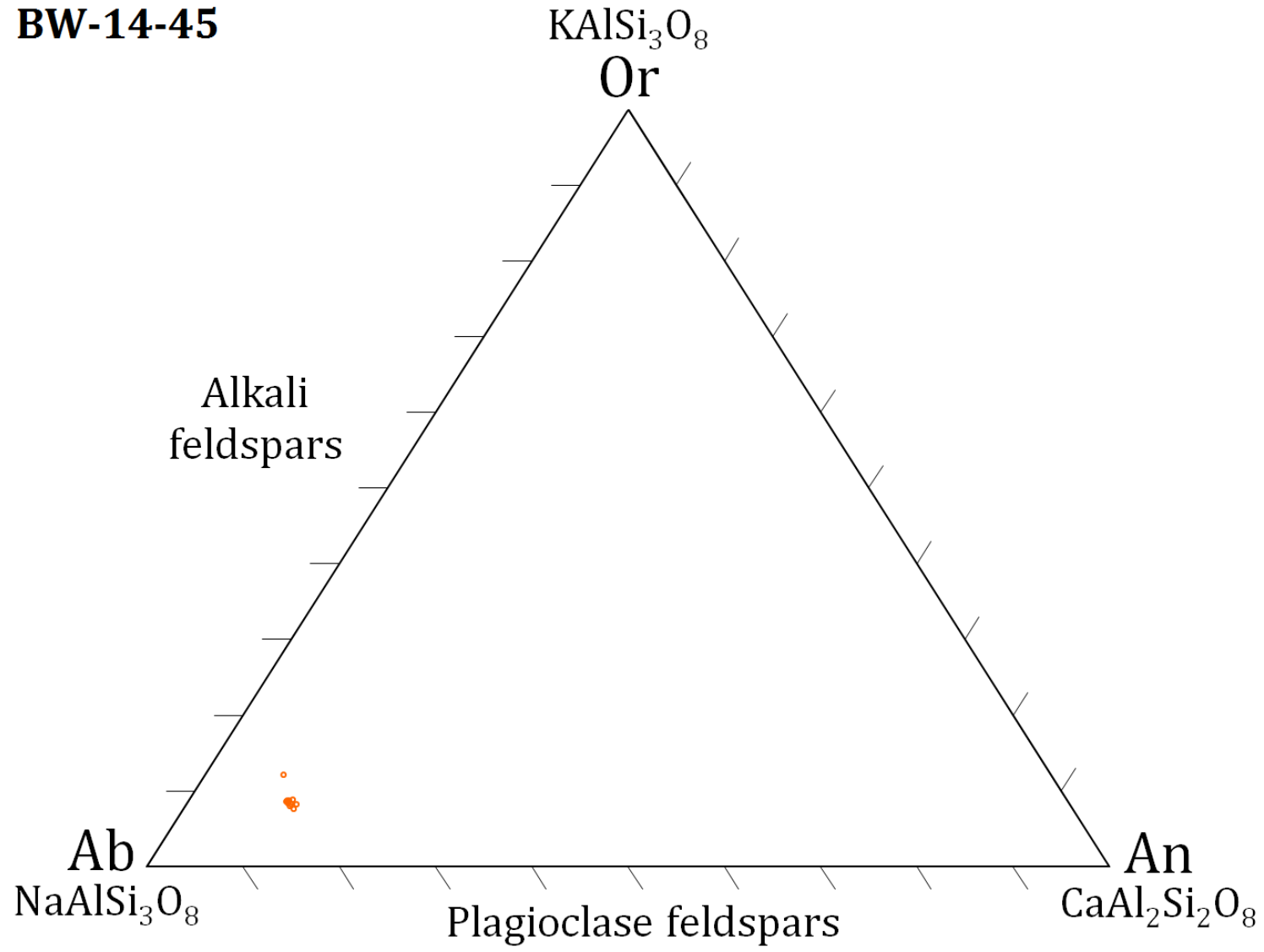

Figure 61: The average, minimum, and maximum calculated end-member compositions from electron Microprobe (EMP) analyses of Dinner Creek Tuff feldspar phenocrysts. Dinner Creek Tuff sample BW-14-45 is petrographically and stratigraphically distinct from the formally recognized Dinner Creek Tuff unit that is mapped throughout the Malheur River Gorge.

Table 13: The average, minimum, and maximum calculated end-member compositions from electron Microprobe (EMP) analyses of Dinner Creek Tuff feldspar phenocrysts.

\begin{tabular}{cccc}
\hline \hline BW-14-45 & \%Or & \%An & \%Ab \\
\hline Max & 12.05 & 11.60 & 81.20 \\
Mean & 8.61 & 10.60 & 80.79 \\
Min & 7.51 & 8.26 & 79.68 \\
\hline
\end{tabular}



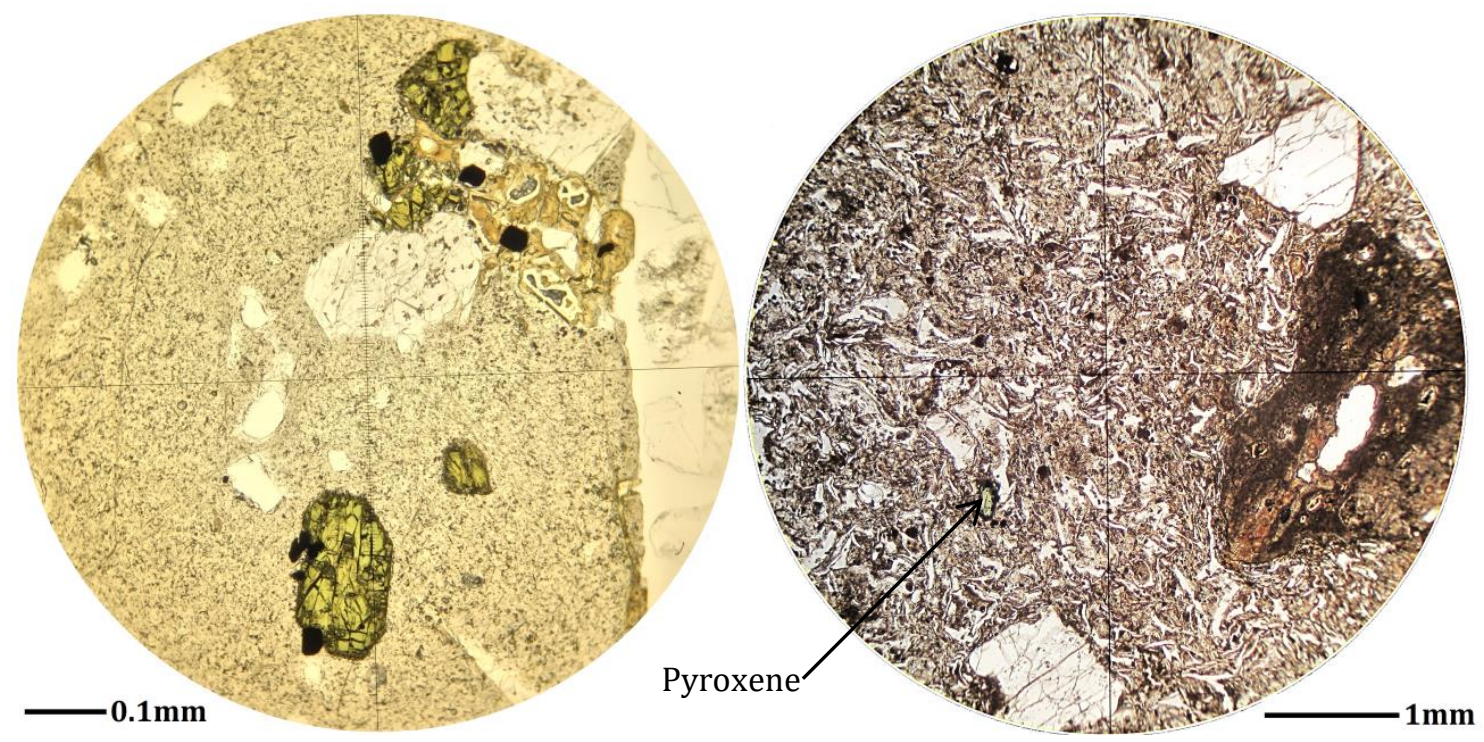

Figure 62: Photomicrographic image of sample BW-14-45, showing a pyroxene phenocryst. Pyroxene is rarely observed in other Dinner Creek Tuff units. Image is taken using plainpolarized light. Sample is geochemically equivalent to Dinner Creek Tuff unit 1 , but is stratigraphically and petrographically distinct. Stratigraphic position of sample source is currently unknown, but emplacement followed that of the commonly observed Dinner Creek Tuff at Namorf.

\section{Pyroclastic Surge Deposits}

One to 2 meter thick pyroclastic surge deposits underlie the upper Littlefield

Rhyolite at the primary transect at Namorf. The surge deposits consist of a matrix of layered, sand-sized sediment, supporting scattered, angular, cobble-sized lithic clasts. Surge deposits are absent in the Alder Creek Canyon transect to the south, and would be buried, if present, further to the north. 


\section{DISCUSSION}

\section{Flood Rhyolites: Effective Viscosity and Lava Flow Morphology of Large Hotspot-related Rhyolites}

The Littlefield Rhyolite consists of at least two distinct widespread lava flows, both of which display morphological features that are, (1) non-typical with respect to flow dimensions of the majority of rhyolite lava flows worldwide, and (2) similar to a limited number of Miocene rhyolite lava flows found within the Snake River Plain of Central Idaho. The dominant rheological parameter that determines relative differences in flow dimensions is the effective viscosity of the erupting lava. Typical low-volume, high aspect ratio silicic coulees erupt at temperatures of approximately $750^{\circ} \mathrm{C}$ and have exceedingly high effective viscosity. In contrast, Snake River-type silicic lavas erupted at temperatures around $1000^{\circ} \mathrm{C}$ and had significantly lower effective viscosities. Similarly, Littlefield rhyolites appear to have erupted at exceedingly high temperatures, having relatively low effective viscosities that allowed them to be widely distributed over significant distances. Littlefield rhyolites represent the western-most examples of hot-spot related, Snake River-type silicic volcanism.

\section{Rhyolite Lava Flow Morphology}

One aspect that is intriguing about the Littlefield rhyolites is their significant radial extent; both units are absolutely massive in size for being rhyolitic lavas. Individual flows can be up to $100 \mathrm{~m}$ thick and extend at least $40 \mathrm{~km}$. These sorts of parameters are quite common with rhyolitic ignimbrites, but are rarely seen with rhyolitic lavas due to their exceptionally high viscosities. Given the thickness and radial extent of 
the Littlefield Rhyolite, it has a low aspect ratio that is uncharacteristic of typical rhyolitic lavas. It's clear that eruptions and emplacement of Littlefield Rhyolite lavas occurred at uncharacteristically high temperatures, which would lower the effective viscosity, thereby allowing silicic lavas to flow in manner more commonly observed with some mafic lava flows.

Typical high volume silicic eruptions involve Plinian-type volcanic eruptions, which produce fallout layers of pumice lapilli along with minor amounts of lithic clasts, leading to deposition of pumice lapilli-bearing ignimbrites. These high volume events are typically paired with relatively small volume extrusions of domes and coulees of degassed silicic lava. In contrast to the general trend, some volcanic fields produce significantly different silicic eruption products, examples of which can be found in the central part of the Snake River Plain, in Southern Idaho and Northcentral Nevada, USA. Miocene rhyolitic volcanism was extensive in these areas, and produced volcanic deposits that are significantly different than the conventional trend of Plinian and ignimbrite eruptions found elsewhere throughout the world, including other Miocene rhyolites that erupted in the Basin and Range province.

\section{High Temperature, Hot-spot Related, Rhyolite Lava Flow Morphology}

Snake River type silicic lavas are more voluminous, have relatively greater radial extent, and lower aspect ratios than non-Snake River type silicic lavas (Branney et al., 2007). Figure 64 shows the stark contrast between the morphology of Snake River silicic volcanism and that of 'typical' silicic volcanism found in other provinces. 


\section{Littlefield Rhyolites Flow Morphology}

The morphology of the upper Littlefield Rhyolite is strikingly similar to the Snake River-type rhyolite lava morphology illustrated in Figure 63, and the upper rhyolite is undoubtedly a lava. The morphology of the lower Littlefield Rhyolite is less obvious, and Lees (1995) tentatively suggested that the lower Littlefield Rhyolite might be an ignimbrite, based on glass shard textures that were reportedly observed in a thin-section. The base of the lower Littlefield Rhyolite is only exposed at an outcrop in the Malheur River Gorge. A thin-section of a porous-looking sample from the base of the lower rhyolite shows micro-brecciated texture consistent with rhyolitic lavas. We observed no vitroclastic textures in any thin-sections. In other areas, flow lobes of the lower rhyolite forms large inflation structures that are consistent with lava flows.
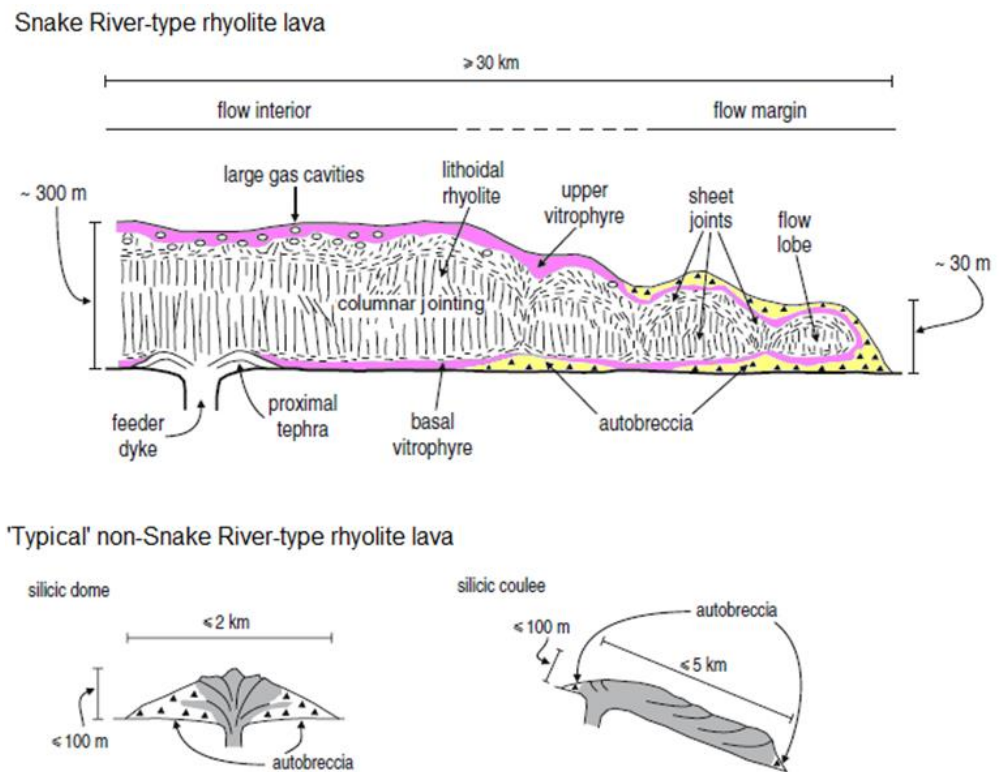

silicic coulee

Figure 63: Characteristic features of Snake River-type rhyolite lavas contrasted with those typical of other volcanic regions. Snake River-type lavas are much more voluminous, more extensive, and have lower aspect ratios than 'typical' non-Snake River-type lavas. Modified figure is from Branney, et al. (2007). 


\section{Geochemical Correlations of Basalt of Malheur Gorge, Hunter Creek Basalt, and Main Phases of the Columbia River Basalt Group}

Geochemical data acquired by prior investigators in the Malheur River Gorge has been largely limited to XRF analysis, which has supported the division of basalt of Malheur Gorge lavas into three distinct formations, and these were used to correlate Malheur River Gorge units with main-phase CRBG units (Ferns et al., 1993; Hooper et al, 2002, Cummings et al., 2000). Here we present ICP-MS data that add further support to the work of prior investigators, confirming that Birch Creek and Hunter Creek Basalt lavas represent late-stage Grande Ronde volcanism (Figure 64), that upper Pole Creek lavas are correlated with Imnaha Basalt (Figure 65), and that lower Pole Creek lavas are correlated with lavas of upper Steens Basalt (Figure 66).

Samples of Birch Creek lavas were collected near the primary transect site at Namorf. A single upper Pole Creek lava is exposed at the base of an isolated stratigraphic section of basalt Malheur Gorge lavas, which has been exposed by normal faulting and truncated by erosion, and is observed adjacent to Littlefield Rhyolite exposures in the Malheur River Gorge. The upper Pole Creek lava is the lowest exposed unit, and is overlain by at least three Birch Creek lavas. Hunter Creek Basalt samples were collected within the Malheur River Gorge and throughout areas to the north. A sample of lower Pole Creek, sample CAH16-061A, has been provided by courtesy of Cahoon, E.B. (unpublished data) and was collected at the Pole Creek formation type section (informal), along Pole Creek Road. Jarboe et al. (2006) acquired a ${ }^{40} \mathrm{Ar} /{ }^{39} \mathrm{Ar}$ age date of $16.49 \pm 0.09 \mathrm{Ma}$ from a sample of the same 
unit as sample CAH16-061A, which they identify as being a sample of upper Pole Creek.

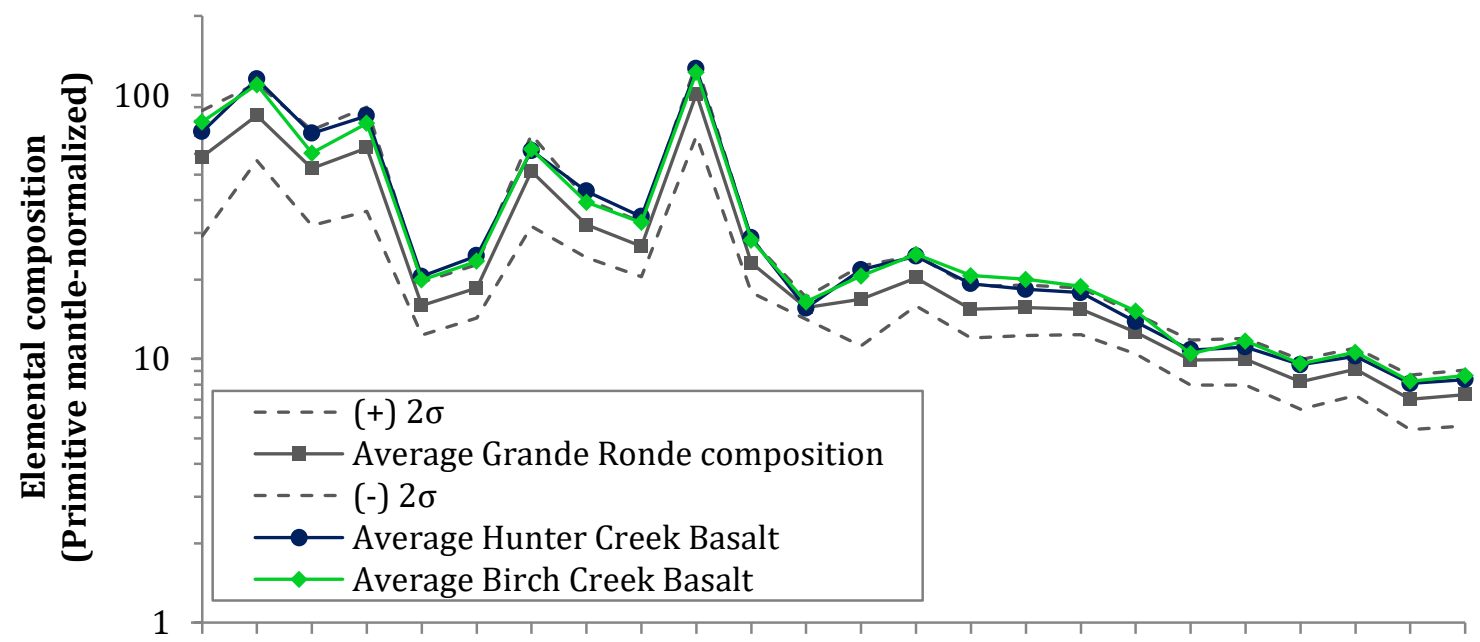

Rb Ba Th U Nb Ta K La Ce Pb Pr Sr P Nd Zr Hf Sm Eu Ti Dy Y Ho Yb Lu

Figure 64: Primitive mantle-normalized, average elemental compositions of Hunter Creek and Birch Creek samples, compared to the average composition $( \pm 2 \sigma)$ of 39 samples of Grande Ronde Basalt. Hunter Creek and Birch Creek units have relatively higher concentrations of incompatible elements, consistent with late-stage Grande Ronde magmatism. Grande Ronde Basalt geochemical data are from Wolff et al. (2008). Normalization values from Sun \& McDonough (1989).

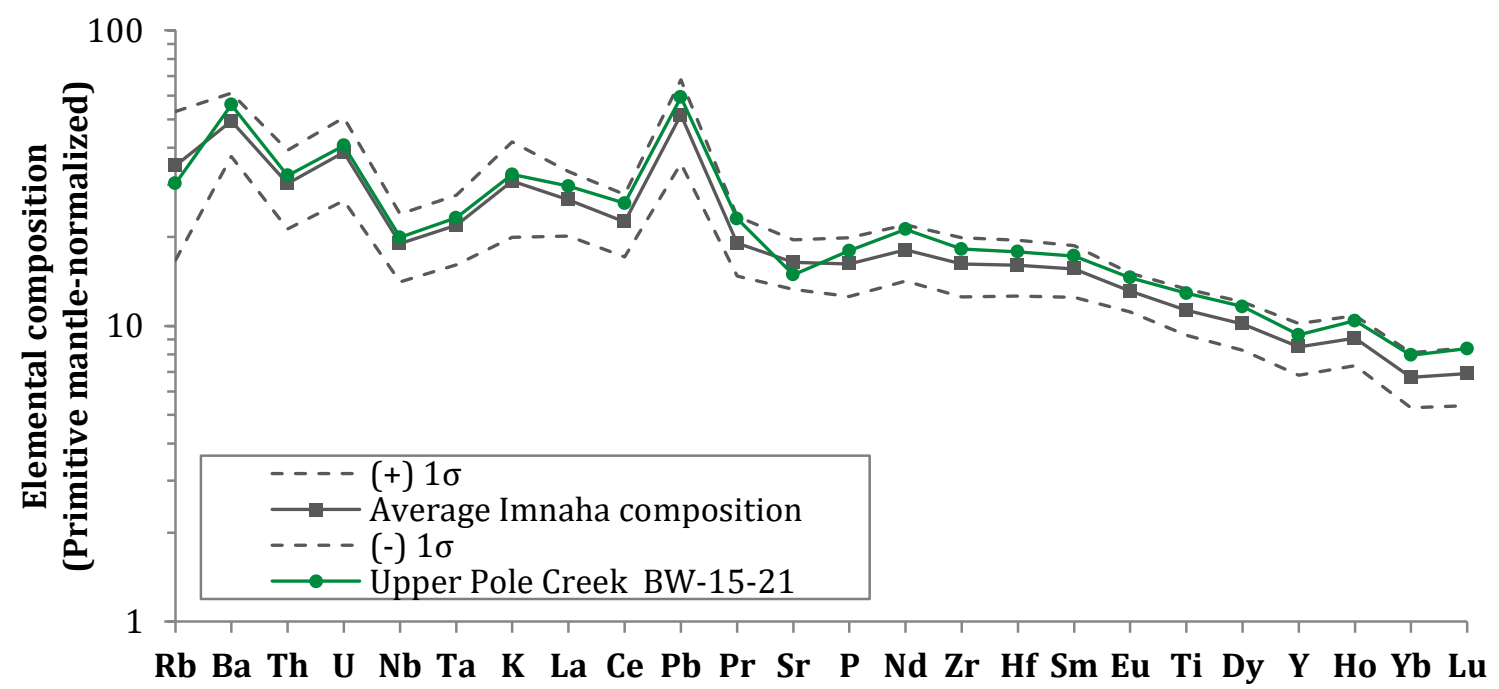

Figure 65: Primitive mantle-normalized, elemental composition of a sample of basalt Malheur Gorge (upper Pole Creek formation), compared to the average composition $( \pm 1 \sigma)$ of 51 samples of Imnaha Basalt. Imnaha Basalt geochemical data are from Wolff et al. (2008). Normalization values from Sun \& McDonough (1989). 


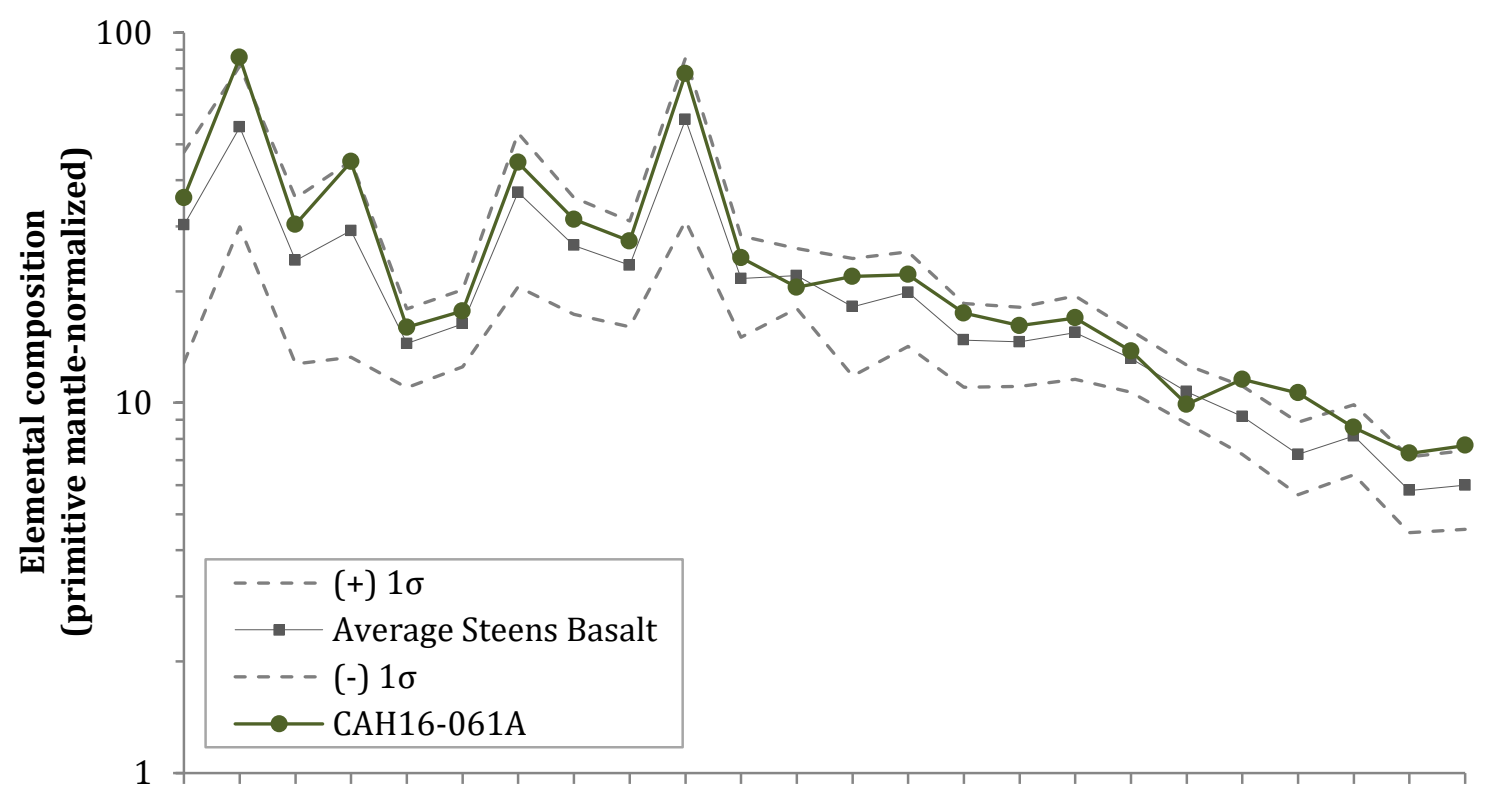

Rb Ba Th U Nb Ta K La Ce Pb Pr Sr P Nd Zr Hf Sm Eu Ti Dy Y Ho Yb Lu

Figure 66: Primitive mantle-normalized, elemental composition of a sample of basalt of Malheur Gorge (lower Pole Creek formation), compared to the average composition $( \pm 1 \sigma)$ of 61 samples of Steens Basalt. Steens Basalt geochemical data are from Wolff et al. (2008). Normalization values from Sun \& McDonough (1989).

Reidel \& Tolan (2013) correlate Hunter Creek lavas with the Wapshilla Ridge Member of Grande Ronde Basalt, based on similar geochemistry and shared R2 magnetostratigraphy. While acknowledging that Birch Creek lavas share similar geochemistry with Hunter Creek and Wapshilla Ridge units, Reidel \& Tolan (2013) nevertheless consider Birch Creek lavas to be a distinct Grande Ronde member, due to their R1 magnetostratigraphy.

These interpretations fail to acknowledge two important observations: (1) In contrast to Birch Creek and Wapshilla Ridge lavas, Hunter Creek Basalt lavas erupted locally within the Malheur River Gorge area, far south of the Chief Joseph dike swarms that are associated with the outpourings of Grande Ronde lavas, including Wapshilla Ridge units. Hunter Creek Basalt vents can be observed near the 
town of Westfall (Ferns \& McClaughry, 2013) and along the Malheur River near Namorf. (2) In contrast to Hunter Creek Basalt lavas, Birch Creek lavas increase in number with distance travelled north-northeast away from the Malheur River Gorge, which suggests that Birch Creek lavas erupted in the north and flowed southward into the greater Malheur River Gorge area. The distribution of Birch Creek lavas and concentration of numerous flows near the proposed type section of Lees (1994), suggest that Birch Creek lavas may turn out be laterally continuous with recognized Grande Ronde stratigraphy in the Weiser Embayment.

Nevertheless, what is important to note here is that Hunter Creek Basalt is geochemically indistinguishable from, and is contemporaneous with, late-stage eruptions of Grande Ronde Basalt. Hunter Creek Basalt is distinct from other Grande Ronde Basalt units in that it erupted from vents within the Malheur River Gorge area.

\section{Icelandite of Alder Creek Canyon: A Mixture of Grande Ronde Basalt and Upper Littlefield Rhyolite}

One local variant of late-stage Grande Ronde lava is icelanditic ( 63 wt. \% SiO2) and is found at a number of places including a location near the southern extent of the upper Littlefield Rhyolite. Geochemical modeling strongly suggests that icelandite lavas resulted from mixing of Grande Ronde Basalt and upper Littlefield Rhyolite magmas (Figure 67, Figure 68), thereby tying a Grande Ronde magma storage site to within the greater Malheur River Gorge area and indicating contemporaneity of rhyolitic and Grande Ronde magma reservoirs. 


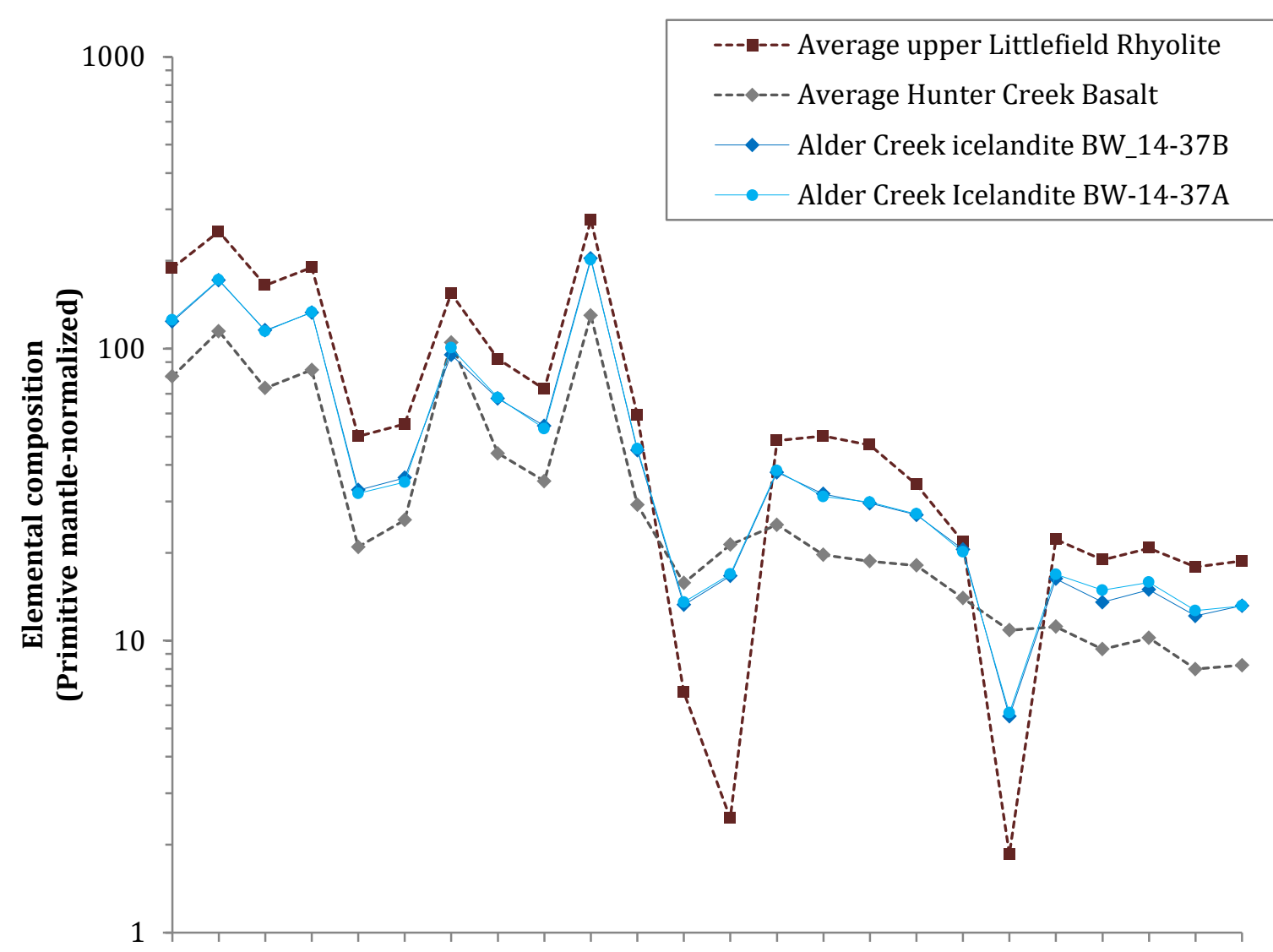

Rb Ba Th U Nb Ta K La Ce Pb Pr Sr P Nd Zr Hf Sm Eu Ti Dy Y Ho Yb Lu

Figure 67: Primitive mantle-normalized elemental composition profiles of two samples of icelandite of Alder Creek Canyon that was collected from the southern transect. The icelandite unit is mapped as Hunter Creek Basalt, given its stratigraphic position. The grey-colored profile shows the average composition of ten samples of Hunter Creek Basalt ( $\left.\sim 55 \mathrm{wt} . \% \mathrm{SiO}_{2}\right)$. The dark red-colored profile shows the average composition of upper Littlefield Rhyolite, which overlies either Hunter Creek Basalt (in the north), or icelandite of Alder Creek Canyon (in the south). Primitive mantle normalization values from Sun \& McDonough (1989).

Figure 67 shows the calculated result of mixing upper Littlefield Rhyolite and Hunter Creek Basalt magmas. The aim of this mixing model is to test the possibility of producing a lava of icelandite of Alder Creek Canyon composition by mixing upper Littlefield Rhyolite with typically observed Hunter Creek Basalt magmas ( 55 wt. $\% \mathrm{SiO}_{2}$ ). The mixing ratio applied in the mixing calculation was determined by performing a linear regression of the ratios of trace element concentrations 
between upper Littlefield Rhyolite, Hunter Creek Basalt, and icelandite of Alder Creek Canyon.

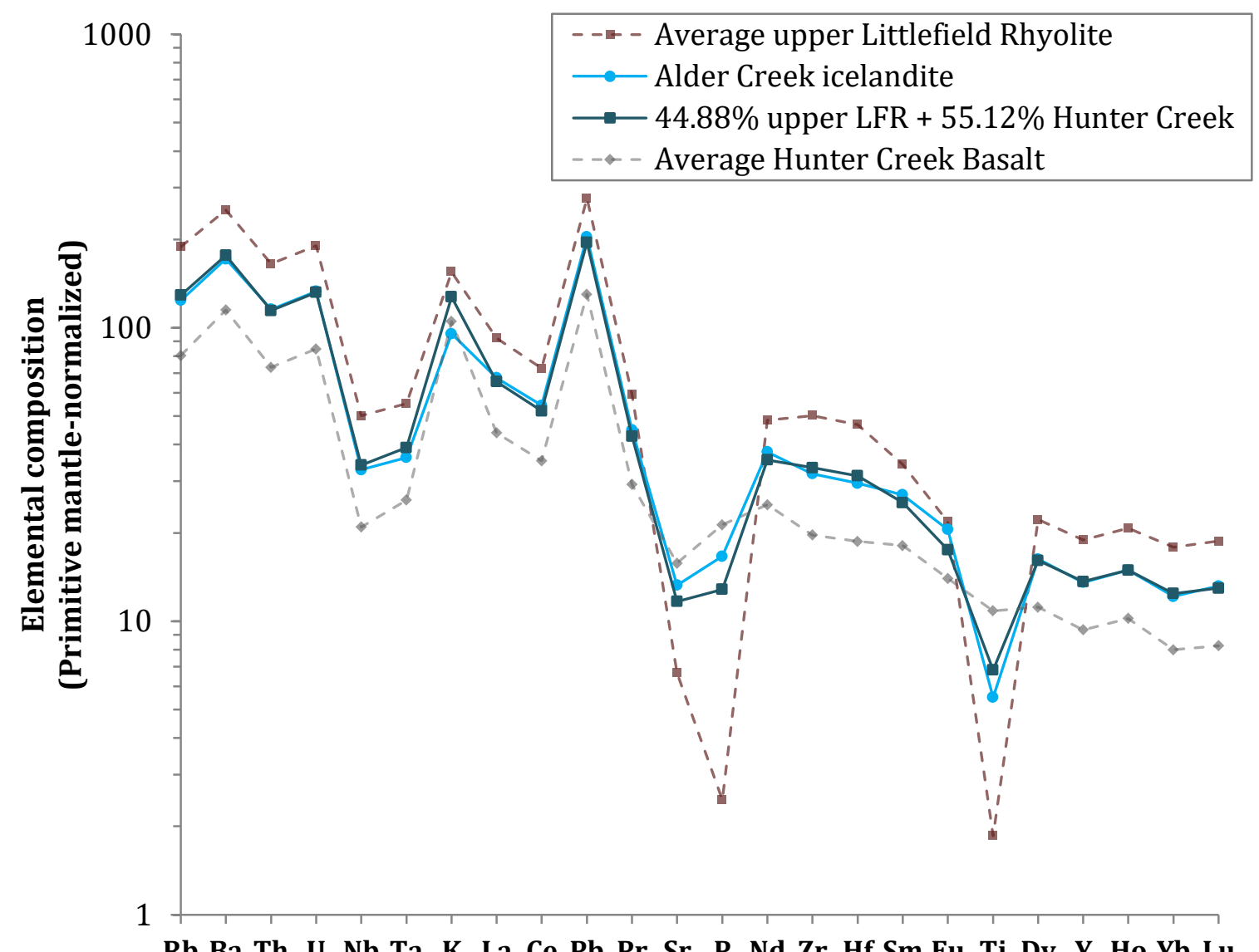

Figure 68: Plot shows the calculated result of mixing upper Littlefield Rhyolite and Hunter Creek Basalt magmas. The calculated results closely match the trace element composition of the icelandite observed in Alder Creek Canyon. 
The mixing ratio derived from differences in trace element concentrations was then used to model the composition of major elements resulting from magma mixing. The calculated major element composition resulting from magma mixing closely matches the bulk composition of icelandite of Alder Creek Canyon (Table 14).

Table 14: Average major element compositions of upper Littlefield Rhyolite (LFR) ( $n=6)$, commonly observed ( 55 wt.\% $\mathrm{SiO}_{2}$ ) Hunter Creek Basalt (HCB) $(n=12)$, icelandite of Alder Creek Canyon, and the calculated result of mixing 55.12\% Hunter Creek Basalt magma with 44.88\% upper Littlefield Rhyolite magma. The calculated major element composition resulting from magma mixing closely resembles icelandite of Alder Creek Canyon, with the exception of wt.\% Mg0, which is notably higher in the mixing calculation.

\begin{tabular}{ccccc}
\hline Unit & $\begin{array}{c}\text { upper Littlefield } \\
\text { Rhyolite }\end{array}$ & $\begin{array}{c}\text { Hunter Creek } \\
\text { Basalt }\end{array}$ & $\begin{array}{c}\text { icelandite of } \\
\text { Alder Creek } \\
\text { Canyon }\end{array}$ & $\begin{array}{c}55.12 \% \text { HCB + } \\
44.88 \% \text { LFR }\end{array}$ \\
\hline $\mathbf{S i O}_{2}$ & 72.01 & 55.66 & 63.13 & 63.07 \\
$\mathbf{T i O}_{2}$ & 0.40 & 2.36 & 1.19 & 1.48 \\
$\mathbf{A l}_{2} \mathbf{O}_{3}$ & 12.53 & 13.59 & 13.15 & 13.11 \\
$\mathbf{F e 0} \mathbf{O}^{*}$ & 4.97 & 12.64 & 10.20 & 9.14 \\
$\mathbf{M n O}$ & 0.12 & 0.20 & 0.21 & 0.16 \\
$\mathbf{M g O}$ & 0.15 & 3.19 & 0.84 & 1.79 \\
$\mathbf{C a O}$ & 1.35 & 6.89 & 3.99 & 4.35 \\
$\mathbf{N a}_{\mathbf{2}} \mathbf{0}$ & 3.75 & 3.07 & 4.05 & 3.43 \\
$\mathbf{K}_{\mathbf{2}} \mathbf{O}$ & 4.66 & 1.94 & 2.87 & 3.19 \\
$\mathbf{P}_{\mathbf{2}} \mathbf{O}_{\mathbf{5}}$ & 0.05 & 0.46 & 0.36 & 0.28 \\
\hline
\end{tabular}

The significance of this geochemical modeling and that icelandite magma was likely produced by mixing upper Littlefield Rhyolite and Hunter Creek Basalt magmas is the following: In order for this mixing to occur, both magmas needed to be in close contact. 


\section{Grande Ronde Basalt Magma Reservoirs Located Beneath the Greater Malheur River Gorge Area}

Hunter Creek Basalt is a late-stage Grande Ronde unit that erupted at superliquidous temperatures from vents within the Malheur River Gorge, alongside outpourings of widespread, high-temperature rhyolite lavas. Petrogenetic ties between this Grande Ronde magma and upper Littlefield Rhyolite suggest the development of a Grande Ronde magmatic reservoir within the greater Malheur River Gorge area that resulted in evolved tholeiitic lavas (icelandites).

The generation of magmas was large-scale, requiring an influx of heat that only a flood basalt province could provide. High temperature eruptions of coeval Hunter Creek Basalt and upper Littlefield Rhyolite suggest that magma, once formed, did not reside for long in the crust (Cummings, personal communication). Additionally, eruptions of Hunter Creek Basalt and upper Littlefield Rhyolite in the greater Malheur River Gorge area establish a locus for these magma reservoirs.

\section{Potential Sources of Crustal Contamination}

Wolff et al. (2008) have shown that Grande Ronde Basalt geochemistry can be modeled as the result of contamination of Imnaha Basalt magmas by cratonic crust. Wolff and Ramos (2013) consider Grande Ronde Basalt to be derived from a single centralized crustal magmatic system, which evolved due to increasing thermal input that incorporated increasing amounts of crustal melts (Wolfe et al., 2008), and that Paleozoic-age accreted arc terranes are too young to provide the low ${ }^{143} \mathrm{Nd} /{ }^{144} \mathrm{Nd}$ ratio required by the crustal contaminant. 
Recent isotope data by Hess (2014) have shown that the rhyolite of Cottonwood Mountain and the upper Littlefield Rhyolite have relatively high ${ }^{87} \mathrm{Sr} /{ }^{86} \mathrm{Sr}$ ratios $\left({ }^{87} \mathrm{Sr} /{ }^{86} \mathrm{Sr}>0.706\right)$. The ${ }^{87} \mathrm{Sr} /{ }^{86} \mathrm{Sr}$ ratios for Littlefield rhyolites are notable given their locations west of the currently recognized cratonic margin, and which appear anomalous relative to other mid-Miocene rhyolites in eastern Oregon.

Isotope geochemistry of Littlefield Rhyolite units and Grande Ronde Basalt are similar in that they both appear to result from melting of cratonic crust. 


\section{CONCLUSIONS}

Upper and lower Littlefield Rhyolites are geochemically distinct, widespread, high temperature rhyolite lavas that, along with the Dinner Creek Tuff, mark the initial onset of bimodal volcanism along the Malheur River Gorge corridor, following the outpouring of flood basalts. Malheur River Gorge stratigraphy reveals a sequence of intercalated Columbia River Basalt Group lavas underlying bimodal stratigraphy. Hunter Creek Basalt was emplaced following the initial rhyolite eruptions. Hunter Creek Basalt is geochemically equivalent to late-stage Grande Ronde Basalt lavas, but is unique to have erupted locally within the greater Malheur River Gorge area. Ages of upper and lower Littlefield Rhyolite flow units constrain the eruption of Hunter Creek Basalt to a minimum age span of $\sim 70 \mathrm{k}$ years, between $16.05-16.12$ Ma, and a maximum age span of $\sim 150 \mathrm{k}$ years, between $16.01-16.16$ Ma. Field observations in the Malheur River Gorge suggest that the emplacement of the bimodal sequence occurred relatively rapidly, preserving the tops of individual flows and preventing the accumulation of sediments and development of soils. One local variant of late-stage Grand Ronde Basalt is icelanditic $\left(\sim 62\right.$ wt. $\left.\% \mathrm{SiO}_{2}\right)$ and is found at a number of places including a location near the southern extent of the upper Littlefield Rhyolite. Geochemical modeling strongly suggests that icelandite lavas resulted from mixing of Hunter Creek Basalt and upper Littlefield Rhyolite magmas, thereby tying a Grande Ronde magma storage site to within the greater Malheur River Gorge area, and indicating contemporaneity of rhyolitic and Grande Ronde magma reservoirs. 


\section{REFERENCES}

Barry, T.L., Kelley, S.P., Reidel, S., Camp, V., Self, S., Jarboe, N., Duncan, R., and Renne, P., 2013, Eruption chronology of the Columbia River Basalt Group, in Reidel, S.P., Camp, V.E., Ross, M.E., Wolff, J.A., Martin, B.S., Tolan, T.L., and Wells, R.E., eds., The Columbia River Flood Basalt Province, Volume 497, Geological Society of America Special Paper, p. 45-66.

Binger, G.B., 1997, The volcanic stratigraphy of the Juntura Region, Eastern Oregon [M.S. thesis]: Washington State University, Pullman, Washington, 206 p.

Boroughs, S., Wolff, J.A., Bonnichsen, B., Godchaux, M., and Larson, P.B., 2005, Large volume, low- $\delta 180$ rhyolites of the central Snake River Plain, Idaho, USA: Geology, v. 33 , no. 10 , p. $821-824$.

Branney, M.J., Bonnichsen, B., Andrews, G.D.M., Ellis, B., Barry, T.L., and McCurry, M, 2007, 'Snake River (SR)-type' volcanism at the Yellowstone hotspot track: distinctive products from unusual, high-temperature silicic super-eruptions: Bulletin of Volcanology, Volume 70, Issue 3, p. 293-314.

Brooks, H.C. and O’Brien, J.P., 1992a, Geology and Mineral Resources Map of the Little Valley Quadrangle, Malheur County, Oregon: Oregon Department of Geology and Mineral Industries, scale 1:24,000, 1 sheet.

Brooks, H.C. and O'Brien, J.P., 1992b, Geology and Mineral Resources Map of the Westfall Quadrangle, Malheur County, Oregon: Oregon Department of Geology and Mineral Industries, scale 1:24,000, 1 sheet.

Camp, V.E., 2013, Origin of Columbia River Basalt: Passive rise of shallow mantle, or active upwelling of a deep-mantle plume?, in Reidel, S.P., Camp, V.E., Ross, M.E., Wolff, J.A., Martin, B.S., Tolan, T.L., and Wells, R.E., eds., The Columbia River Flood Basalt Province, Volume 497, Geological Society of America Special Paper, p. 181199.

Camp, V.E., and Ross, M.E., 2004, Mantle dynamics and genesis of mafic magmatism in the intermontane Pacific Northwest: Journal of Geophysical Research, v. 109, 14 p.

Camp, V.E., and Ross, M.E., 2009. Regional synthesis of Steens Basalt, Columbia River Basalt Group: Geological Society of America Abstracts with Programs 41 (7), 225. 
Camp, V.E., Ross, M.E., and Hanson, W.E., 2003, Genesis of flood basalts and Basin and Range volcanic rocks from Steens Mountain to the Malheur River Gorge, Oregon: Geological Society of America Bulletin, v. 115, p. 105-128.

Chevrel, M.O., Platz, T., Hauber, E., Baratoux, D., Lavallée, Y., and Dingwell, D.B., 2013, Lava flow rheology: A comparison of morphological and petrological methods: Earth and Planetary Science Letters, v. 384, p. 109-120.

Christiansen, E.H., and McCurry, M., 2008, Contrasting origins of Cenozoic silicic volcanic rocks from the western Cordillera of the United States: Bulletin of Volcanology, v. 70, p. 251-267.

Christiansen, R.L., Foulger, G.R., and Evans, J.R., 2002, Upper-mantle origin of the Yellowstone hotspot: Geological Society of America Bulletin, v. 114, p. 1245-1256.

Coble, M.A., and Mahood, G.A., 2012, Initial impingement of the Yellowstone plume located by widespread silicic volcanism contemporaneous with Columbia River flood basalts: Geology, v. 4, p. 655-658.

Coint, N., Barnes, C.G., Yoshinobu, A.S., Barnes, M.A., and Buck, S., 2013a, Use of trace element abundances in augite and hornblende to determine the size, connectivity, timing, and evolution of magma batches in a tilted batholith: Geosphere, v. 9, n. 6, p. 1747-1764.

Coint, N., Barnes, C.G., Yoshinobu, A.S., Chamberlain, K.R., and Barnes, M.A., 2013b, Batch-wise assembly and zoning of a tilted calc-alkaline batholith: Field relations, timing, and compositional variation: Geosphere, v. 9, p. 1729-1746.

Cummings, M.L., Evans, J.G., Ferns, M.L., and Lees, K.L., 2000, Stratigraphic and structural evolution of the middle Miocene synvolcanic Oregon-Idaho graben: Geological Society of America Bulletin, v. 112, n. 5, p. 668-682.

Dickinson, W.R., 2008, Accretionary Mesozoic-Cenozoic expansion of the Cordilleran continental margin in California and adjacent Oregon: Geosphere, n. 4, p. 329-353.

Dorsey, R.J., and LaMaskin, T.A., 2007, Stratigraphic record of Triassic-Jurassic collisional tectonics in the Blue Mountains Province, northeastern Oregon: American Journal of Science, v. 307, p. 1167-1193. 
Dorsey, R.J., and LaMaskin, T.A., 2008, Mesozoic collision and accretion of oceanic terranes in the Blue Mountains province of northeastern Oregon: New insights from the stratigraphic record: Arizona Geological Society Digest, v. 22, p. 325-332.

Edwards, J.H., 2013, Structural Controls of the Neal Hot Springs Geothermal System, Eastern Oregon [M.S. Thesis]: University of Nevada, Reno, Nevada, 92 p.

Elliott, T., 2003, Tracers of the Slab: Inside the Subduction Factory: American Geophysical Union Geophysical Monograph 138, p. 23-45. doi: 10.1029/138GM03

Evans, J.G., 1990, Geology and Mineral Resources Map of the South Mountain Quadrangle, Malheur County, Oregon: Oregon Department of Geology and Mineral Industries Geological Map Series GMS-67, scale 1:24,000, 1 sheet.

Evans, J.G., 1995a, Geologic map of the Hope Butte 7.5' quadrangle, Malheur County, Oregon: unpublished, scale 1:24,000.

Evans, J.G., 1995b, Geologic map of the Swede Flat 7.5' quadrangle, Malheur County, Oregon: unpublished, scale 1:24,000.

Evans, J.G., 1996, Geologic Map of the Monument Peak Quadrangle, Malheur County, Oregon: U.S. Geological Survey Miscellaneous Field Studies, Map MF-2317.

Evans, J.G., and Binger, G.B., 1996, Geologic Map of the Westfall Butte Quadrangle, Malheur County, Oregon: U.S. Geological Survey Open-File Report 97-481.

Evans, J.G., and Binger, G.B., 1999a, Geologic Map of the Shumway Reservoir Quadrangle, Malheur County, Oregon: U.S. Geological Survey Open-File Report 99138.

Evans, J.G., and Binger, G.B., 1999b, Geologic Map of the Skull Springs Quadrangle, Malheur County, Oregon: U.S. Geological Survey Open-File Report 99-331.

Evans, J.G., and Binger, G.B., 1999c, Preliminary Geologic Map of the Star Creek Reservoir 71/2' Quadrangle, Malheur County, Oregon: U.S. Geological Survey OpenFile Report 99-583.

Evans, J.G., and Binger, G.B., 1999d, Geologic Map of the Little Black Canyon Quadrangle, Malheur County, Oregon: U.S. Geological Survey Open-File Report 98493. 
Evans, J.G., and Binger, G.B., 1999e, Geologic Map of the Little Black Canyon Quadrangle, Malheur County, Oregon: U.S. Geological Survey, To Accompany OpenFile Report 98-493

Evans, J.G., and Binger, G.B., 1999f, Geologic Map of the Alder Creek Quadrangle, Malheur County, Oregon: U.S. Geological Survey Open-File Report 98-494.

Evans, J.G., and Keith, W.J., 1996, Geologic Map of the Tims Peak Quadrangle, Malheur County, Oregon, U.S. Geological Survey Miscellaneous Field Studies Map MF-2316.

Ferns, M.L., and O'Brien, J.P., 1992a, Geology and Mineral Resources Map of the Namorf Quadrangle, Malheur County, Oregon: Oregon Department of Geology and Mineral Industries, scale 1:24,000, 1 sheet.

Ferns, M.L. and O'Brien, J.P., 1992b, Geology and Mineral Resources Map of the Harper Quadrangle, Malheur County, Oregon: Oregon Department of Geology and Mineral Industries, scale 1:24,000, 1 sheet.

Ferns, M.L., Brooks, H.V., Evans, J.G., and Cummings, M.L., 1993, Geologic map of the Vale 30 x 60 Minute Quadrangle, Malheur County, Oregon and Owyhee County, Idaho: Oregon Department of Geology and Mineral Industries, scale 1:100,000, 1 sheet.

Ferns, M.L., Evans, J.G., and Cummings, M.L., 1993, Geologic map of the Mahogany Mountain 30 x 60 Minute Quadrangle, Malheur County, Oregon and Owyhee County, Idaho: Oregon Department of Geology and Mineral Industries, scale 1:100,000, 1 sheet.

Ferns, M.L., and McClaughry, J.D., 2013, Stratigraphy and volcanic evolution of the middle Miocene La Grande - Owyhee eruptive axis in eastern Oregon, in Reidel, S.P., Camp, V.E., Ross, M.E., Wolff, J.A., Martin, B.S., Tolan, T.L., and Wells, R.E., eds., The Columbia River Flood Basalt Province, Volume 497, Geological Society of America Special Paper, p. 401-472.

Ferns, M.L., and McClaughry, J.D., Geologic Map of the Brogan 30' x 60' quadrangle, Baker County and Malheur County, Oregon: Unpublished, Scale 1:100,000.

Fiebelkorn, R.B., Walker, G.W., MacLeod, N.S., McKee, E.H., and Smith, J.G., 1983, Index to K-Ar determinations for the State of Oregon: Isochron/West, no. 37, p. 3-60. 
Ford, M.T., Grunder, A.L., and Duncan, R.A., 2013, Bimodal volcanism of the High Lava Plains and northwestern Basin and Range of Oregon: the distribution and tectonic implications of age-progressive rhyolites: Geochemistry Geophysics Geosystems, v. 14, no. 8, p. 2836-2857.

Henry, C.D., and John, D.A., 2013, Magmatism, ash-flow tuffs, and calderas of the ignimbrite flareup in the western Nevada volcanic field, Great Basin, USA: Geosphere, v. 9, p. 951-1008.

Henry, C.D., and Wolff, J.A., 1992, Distinguishing strongly rheomorphic tuffs from extensive silicic lavas: Bulletin of Volcanology, v. 54, p. 171-186.

Hess, E.N., 2014, Stronium, Lead, and Oxygen Isotopic Signatures of Mid-Miocene Silicic Volcanism in Eastern Oregon [M.S. Thesis], Paper 2079: Portland State University, Portland, Oregon, $117 \mathrm{p}$.

Hooper, P.R., Johnson, D.M., Conray, R.M., 1993, Major and trace element analyses of rocks and minerals by automated X-ray spectrometry: Washington State University, Department of Geology, open file report.

Hooper, P.R., Binger, B.G., and Lees, K.L., 2002, Ages of the Steens and Columbia River flood basalts and their relationship to extension-related calc-alkalic volcanism in eastern Oregon: Geological Society of America Bulletin, v. 114, n. 1, p. 43-50.

Hooper, P.R., Binger, B.G., and Lees, K.L., 2002, Vale Project Analyses: Whole Rock Major and Trace Element Analysis by XRF. GeoAnalytical Laboratory, Washington State University. (Samples collected by Jim Evans, Mark Ferns, Howard Brooks, Jenda Johnson, Kate Lees, Mandi Francis, Ben Binger, Chris Hawkesworth, and Peter Hooper.)

Jarboe, N.A., Coe, R.S., Renne, P.R., and Glen, J.M.G., 2010, The age of the Steens reversal and the Columbia River Basalt Group: Chemical Geology, v. 274, p. 159-168.

Johnson, D.M., Hooper, P.R., and Conrey, R.M., 1999, XRF analysis of rocks and minerals for major and trace elements on a single low dilution Li-tetraborate fused bead: Advances in X-ray Analysis, v. 41, p. 843-867.

Jourdan, F., and Renne, P.R., 2007, Age calibration of the Fish Canyon sanidine ${ }^{40} \mathrm{Ar} /{ }^{39} \mathrm{Ar}$ dating standard using primary $\mathrm{K}-\mathrm{Ar}$ standards: Geochimica et Cosmochimica Acta, v. 71, p. 387-402. 
Kittleman, L.R., Green, A.R., Haddock, G.H., Hagood, A.R., Johnson, A.M., McMurray, J.M., Russell, R.G., and Weeden, D.A., 1967, Geologic map of the Owyhee region, Malheur County, Oregon: Eugene, University of Oregon Museum of Natural History Bulletin 8, scale 1:125 000.

Kittleman, L.R., Green, A.R., Hagood, A.R., Johnson, A.M., McMurray, J.M., Russell, R.G., and Weeden, D.A., 1965, Cenozoic stratigraphy of the Owyhee region, southeastern Oregon: Eugene, University of Oregon Museum of Natural History Bulletin 1, 45 p.

Knaack, C., Cornelius, S., and Hooper, P.R., 1994, Trace element analysis of rocks and minerals by ICP-MS: Washington State University, $18 \mathrm{p}$.

Kuiper, K.F., Deino, A., Hilgen, F.J., Krijgman, W., Renne, P>R>, and Wijbrans, J.R., 2008, Synchronizing rock clocks of Earth history: Science, v. 320, p. 500-504.

Le Bas, M.J., Le Maitre, R.W., Streckeisen, A., and Zanettin, B., 1986, A chemical classification of volcanic rocks based on the total alkali - silica diagram: Journal of Petrology, v. 27, p. 745-750.

Lees, K.R., 1994, Magmatic and tectonic changes through time in the Neogene volcanic rocks of the Vale Area, Oregon, Northwestern USA [Ph.D. thesis]: Department of Earth Sciences, The Open University, Milton Keynes, 284 p.

Ma, L., Madin, I.P., Olson, K.V., and Watzig, R.J., 2009, Oregon Geological Data Compilation: Oregon Department of Geology and Mineral Industries, v. 5.

McDonough, W.F., and Sun, S.-s., 1995, The composition of the Earth: Chemical Geology, v. 120, p. 223-253.

Nelson, S. and Carmichael, I., 1979, Partial molar volumes of oxide components in silicate liquids: Contributions in Mineralogy \& Petrology, v. 71, p. 117-124.

Nichols, B., 1939, Viscosity of lava: Journal of Geology, v. 47, p. 290-302.

Reidel, S.P., 1998, Emplacement of Columbia River flood basalt: Journal of Geophysical Research-Solid Earth 103 (B11), 27393-27410.

Reidel, S.P., Tolan, T.L., 2013, The Grande Ronde Basalt, Columbia River Basalt Group: The Geological Society of America Special Paper 497, p. 117-153.

Richards, M.A., Duncan, R.A., and Courtillot, V.E., 1989, Flood basalts and hot-spot tracks: Plume heads and tails: Science, New Series, v. 246, n. 4926, p. 103-107. 
Ross, J.I., 2014, Geochronology of Southern McMurdo Sound and development of Pychron: A ${ }^{40} \mathrm{Ar} /{ }^{39} \mathrm{Ar}$ data collection and processing suite [PhD dissertation]: Socorro, New Mexico Institute of Mining and Technology, $302 \mathrm{p}$.

Rudnick, R.L. and Fountain D.M., 1995, Nature and composition of the continental crust: A lower crustal perspective: Rev. Geophys, v. 33(3), p. 267-309.

Rudnick, R.L., and Gao, S., 2003, The composition of the continental crust: Rudnick, R.L., ed., In the crust, Oxford, Elsevier-Pergamon, v. 3, 64 p.

Shaw, H. R., 1965, Comments on viscosity, crystal settling, and convection in granitic magmas: Am. J. Sci.., v. 263, p. 120-152.

Streck, M.J., and Grunder, A.L., 1999, Enrichment of basalt and mixing of dacite in the rootzone of a large rhyolite chamber: Inclusions and pumices from the Rattlesnake Tuff, Oregon: Contributions to Minerology and Petrology, v. 136, p. 193-212.

Streck, M.J., 2002, Partial melting to produce high-silica rhyolites of a bimodal suite: Compositional constraints among rhyolites, basalts, and metamorphic xenoliths from the Harney Basin, Oregon: International Journal of Earth Science, v. 91, p. 583593.

Streck, M.J., and Ferns, M.L., 2004, The Rattlesnake Tuff and other Miocene silicic volcanism in eastern Oregon: U.S. Geological Survey Open-File Report, v. 2004, no. 1222, p. 4.

Streck, M.J., and Grunder, A.L., 2008, Phenocryst-poor rhyolites of bimodal, tholeiitic provinces: the Rattlesnake Tuff and implications for mush extraction models: Bulletin of Volcanology, v. 70, p. 385-401.

Streck, M.J., Ferns, M.L., and McIntosh, W.C., 2015, Large, persistent rhyolitic magma reservoirs above Columbia River Basalt storage sites: The Dinner Creek Tuff Eruptive Center, eastern Oregon: Geosphere, v. 11, n. 2, p. 1-10.

Sun, S.-s., and McDonough, W.F., 1989, Chemical and isotopic systematics of oceanic basalts: implications for mantle composition and processes: Geological Society, London, Special Publications, v. 42, p. 313-345.

Taylor, S.R., and McLennan, S.M., 1985, The Continental Crust: Its Composition and Evolution: Blackwell, Cambridge, Mass., 312 p. 
Tolan, T.L., Martin, B.S., Reidel, S.P., Anderson, J.L., Lindsey, K.A., and Burt, W., 2009, An introduction to the stratigraphy, structural geology, and hydrogeology of the Columbia River Flood-Basalt Province: A primer for the GSA Columbia River Basalt Group field trips, in O'Connor, J.E., Dorsey, R.J., and Madin, I.P., eds., Volcanoes to Vineyards: Geologic Field Trips through the Dynamic Landscape of the Pacific Northwest, Geological Society of America Field Guide, v. 15, p. 599-643.

Watts, K.E., Bindeman, I.N., and Schmitt, A.K., 2011, Large-volume rhyolite genesis in caldera complexes of the Snake River Plain: insights from the Kilgore Tuff of the Heise Volcanic Field, Idaho, with comparison to Yellowstone and Bruneau-Jarbidge rhyolites: Journal of Petrology, v. 52, p. 857-890.

Wolff, J.A., and Ramos, F.C., 2013, Source materials for the main phase of the Columbia River Basalt Group: Geochemical evidence and implications for magma storage and transport: Geological Society of America Special Paper 497, p. 273-291.

Wolff, J.A., Ramos, F.C., Hart, G.L., Patterson, J.D., and Brandon, A.D., 2008, Columbia River flood basalts from a centralized crustal magmatic system: Nature Geoscience, v. 1 , p. 177-180.

Wood, S.H. and Clemens, D.M., 2000, Geologic and tectonic history of the western Snake River Plain, Idaho and Oregon: Tectonic and Magmatic Evolution of the Snake River Plain Volcanic Province: Idaho Geological Survey Bulletin 30, p. 69-103. 
APPENDIX A: XRF \& ICP-MS CHEMICAL DATA

\section{X-Ray Fluorescence (XRF) and ICP-MS Sample Location Map}

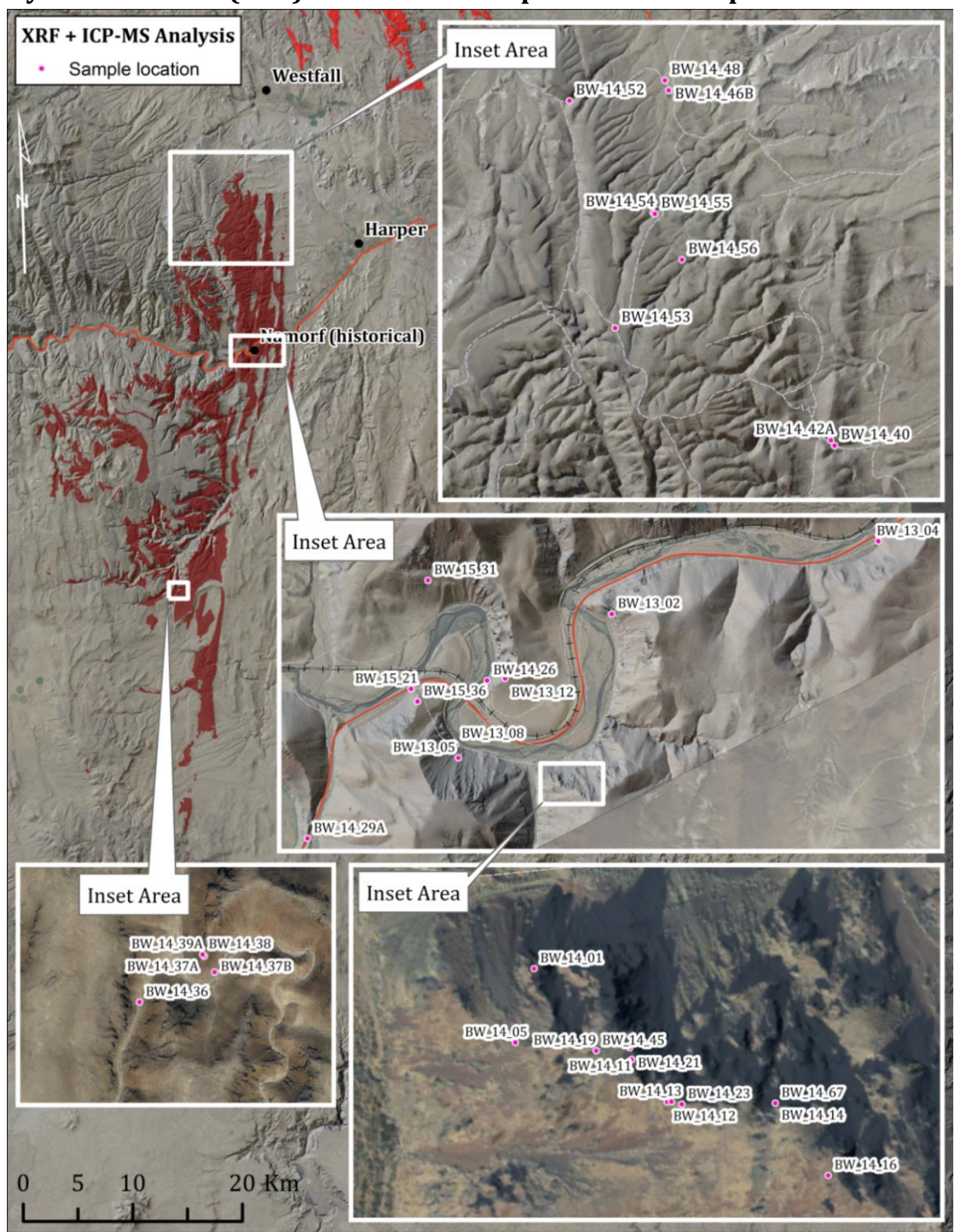

Figure 69: Geochemical sample location map for 40 of 41 samples. Sample BW-15-04 (Hunter Creek Basalt) is not shown, but was collected along Bonita Rd., north of Westfall. 


\section{X-Ray Fluorescence (XRF) Chemical Data}

Table 15: XRF major and trace element compositions of icelandite of Alder Creek Canyon and basalt of Malheur Gorge samples. Icelandite of Alder Creek Canyon is stratigraphically equivalent to Hunter Creek Basalt. Sample locations are given in North American Datum 1983, Universal Transverse Mercator (UTM), Zone 11N.

\begin{tabular}{|c|c|c|c|c|c|}
\hline Sample ID & "BW_14_37A & "BW_14_37B & "BW_15_31 & "BW_15_36 & "BW_15_21 \\
\hline Easting, m & 433140 & 433167 & 440007 & 439901 & 439860 \\
\hline Northing, m & 4826063 & 4826016 & 4848286 & 4847461 & 4847548 \\
\hline Elevation, m & 1264 & 1237 & 927 & 880 & 821 \\
\hline $\begin{array}{l}\text { USGS Quad } \\
\text { Name }\end{array}$ & Alder Creek & Alder Creek & Namorf & Namorf & Namorf \\
\hline Unit name & $\begin{array}{c}\text { Alder Creek } \\
\text { icelandite }\end{array}$ & $\begin{array}{c}\text { Alder Creek } \\
\text { icelandite }\end{array}$ & Birch Creek & Birch Creek & $\begin{array}{l}\text { Upper Pole } \\
\text { Creek }\end{array}$ \\
\hline \multicolumn{6}{|c|}{$X R F$, normalized wt.\% } \\
\hline $\mathrm{SiO}_{2}$ & 63.28 & 63.13 & 57.43 & 55.74 & 51.88 \\
\hline $\mathrm{TiO}_{2}$ & 1.23 & 1.19 & 2.30 & 2.24 & 2.80 \\
\hline $\mathrm{Al}_{2} \mathbf{O}_{3}$ & 13.31 & 13.15 & 13.75 & 13.79 & 14.45 \\
\hline $\mathrm{FeO}^{*}$ & 9.92 & 10.20 & 10.87 & 12.54 & 13.37 \\
\hline MnO & 0.20 & 0.21 & 0.26 & 0.21 & 0.22 \\
\hline MgO & 0.82 & 0.84 & 2.86 & 3.43 & 3.59 \\
\hline $\mathrm{CaO}$ & 4.09 & 3.99 & 6.39 & 6.94 & 9.11 \\
\hline $\mathrm{Na}_{2} \mathrm{O}$ & 3.76 & 4.05 & 3.30 & 3.28 & 3.22 \\
\hline $\mathrm{K}_{2} \mathbf{O}$ & 3.03 & 2.87 & 2.28 & 1.48 & 0.98 \\
\hline $\mathbf{P}_{2} \mathbf{O}_{5}$ & 0.37 & 0.36 & 0.56 & 0.34 & 0.39 \\
\hline \multicolumn{6}{|l|}{$X R F, p p m$} \\
\hline $\mathbf{N i}$ & 2 & 0 & 8 & 4 & 36 \\
\hline $\mathrm{Cr}$ & 0 & 0 & 0 & 0 & 45 \\
\hline Sc & 23 & 22 & 30 & 31 & 38 \\
\hline V & 5 & 5 & 228 & 307 & 412 \\
\hline $\mathbf{B a}$ & 1198 & 1189 & 841 & 699 & 411 \\
\hline $\mathbf{R b}$ & 81 & 81 & 60 & 44 & 20 \\
\hline $\mathrm{Sr}$ & 280 & 270 & 342 & 344 & 314 \\
\hline $\mathbf{Z r}$ & 357 & 356 & 243 & 207 & 201 \\
\hline $\mathbf{Y}$ & 67 & 62 & 48 & 38 & 42 \\
\hline $\mathbf{N b}$ & 24.3 & 24.2 & 15.1 & 13.1 & 14.1 \\
\hline Ga & 23 & 23 & 22 & 22 & 21 \\
\hline $\mathrm{Cu}$ & 5 & 4 & 22 & 12 & 154 \\
\hline Zn & 156 & 159 & 137 & 127 & 134 \\
\hline $\mathbf{P b}$ & 14 & 14 & 10 & 8 & 4 \\
\hline La & 45 & 41 & 28 & 23 & 17 \\
\hline Ce & 95 & 93 & 65 & 56 & 43 \\
\hline Th & 10 & 10 & 6 & 6 & 3 \\
\hline Nd & 50 & 49 & 38 & 30 & 27 \\
\hline $\mathbf{U}$ & 3 & 4 & 1 & 3 & 2 \\
\hline
\end{tabular}


Table 16: XRF major and trace element compositions of tuffaceous samples. Sample locations are given in North American Datum 1983, Universal Transverse Mercator (UTM), Zone 11N.

\begin{tabular}{|c|c|c|c|c|c|}
\hline Sample ID & "BW_14_14 & PW_14_38 & BW_14_45 & BW_14_52 & BW_14_12 \\
\hline Easting, $\mathrm{m}$ & 440948 & 433135 & 440827 & 436736 & 440874 \\
\hline Northing, m & 4846821 & 4826068 & 4846862 & 4864749 & 4846825 \\
\hline Elevation, m & 972 & 1266 & 920 & 1117 & 946 \\
\hline $\begin{array}{l}\text { USGS Quad } \\
\text { Name }\end{array}$ & Namorf & Alder Creek & Namorf & $\begin{array}{l}\text { Little Black } \\
\text { Canyon }\end{array}$ & Namorf \\
\hline Unit name & $\begin{array}{l}\text { Dacite welded } \\
\text { tuff }\end{array}$ & $\begin{array}{l}\text { Dacite welded } \\
\text { tuff }\end{array}$ & $\begin{array}{l}\text { Dinner Creek } \\
\text { Tuff }\end{array}$ & $\begin{array}{l}\text { Welded tuff, } \\
\text { altered }\end{array}$ & Epiclastic tuff \\
\hline \multicolumn{6}{|c|}{$X R F$, normalized wt.\% } \\
\hline $\mathrm{SiO}_{2}$ & 67.31 & 64.62 & 75.17 & 80.18 & 74.76 \\
\hline $\mathrm{TiO}_{2}$ & 1.91 & 1.25 & 0.19 & 0.16 & 0.14 \\
\hline $\mathrm{Al}_{2} \mathrm{O}_{3}$ & 15.84 & 16.43 & 12.57 & 9.98 & 12.76 \\
\hline $\mathrm{FeO}^{*}$ & 7.14 & 8.64 & 2.41 & 1.96 & 3.27 \\
\hline Mno & 0.05 & 0.14 & 0.05 & 0.01 & 0.04 \\
\hline MgO & 2.22 & 1.08 & 0.49 & 0.17 & 1.51 \\
\hline $\mathrm{CaO}$ & 2.38 & 3.61 & 0.80 & 0.92 & 0.92 \\
\hline $\mathrm{Na}_{2} \mathrm{O}$ & 1.38 & 2.39 & 2.41 & 3.38 & 2.07 \\
\hline $\mathbf{K}_{2} \mathbf{O}$ & 1.58 & 1.48 & 5.89 & 3.20 & 4.52 \\
\hline $\mathbf{P}_{2} \mathbf{O}_{5}$ & 0.21 & 0.35 & 0.03 & 0.03 & 0.02 \\
\hline \multicolumn{6}{|l|}{$X R F, p p m$} \\
\hline $\mathbf{N i}$ & 6 & 6 & 1 & 2 & 0 \\
\hline $\mathrm{Cr}$ & 5 & 10 & 3 & 4 & 3 \\
\hline Sc & 22 & 19 & 4 & 4 & 4 \\
\hline $\mathbf{V}$ & 143 & 107 & 8 & 20 & 12 \\
\hline Ba & 458 & 790 & 1273 & 1116 & 42 \\
\hline $\mathbf{R b}$ & 54 & 48 & 82 & 52 & 120 \\
\hline $\mathrm{Sr}$ & 142 & 246 & 37 & 36 & 21 \\
\hline $\mathbf{Z r}$ & 270 & 283 & 434 & 341 & 244 \\
\hline $\mathbf{Y}$ & 56 & 61 & 85 & 31 & 63 \\
\hline Nb & 18.8 & 17.3 & 24.6 & 19.1 & 19.7 \\
\hline Ga & 22 & 21 & 21 & 17 & 17 \\
\hline $\mathrm{Cu}$ & 15 & 30 & 4 & 3 & 4 \\
\hline $\mathbf{Z n}$ & 149 & 145 & 152 & 109 & 113 \\
\hline $\mathbf{P b}$ & 11 & 14 & 18 & 16 & 26 \\
\hline $\mathbf{L a}$ & 32 & 35 & 43 & 17 & 27 \\
\hline $\mathrm{Ce}$ & 60 & 71 & 83 & 81 & 60 \\
\hline Th & 8 & 7 & 8 & 6 & 14 \\
\hline $\mathbf{N d}$ & 36 & 37 & 44 & 11 & 31 \\
\hline $\mathbf{U}$ & 3 & 1 & 2 & 3 & 4 \\
\hline
\end{tabular}


Table 17: XRF major and trace element compositions of Hunter Creek Basalt samples. Samples BW-13-05, BW-13-09, and BW-13-12 are agglutinated spatter. BW-13-10 is scoria. All remaining Hunter Creek Basalt samples are lavas. Sample locations are given in North American Datum 1983, Universal Transverse Mercator (UTM), Zone 11N.

\begin{tabular}{|c|c|c|c|c|c|c|}
\hline "Sample ID & BW_13_05 & "BW_13_09 & "BW_13_10 & BWW_13_12 & "BW_14_11 & "BW_14_13 \\
\hline Easting, $\mathrm{m}$ & 440163 & 440504 & 440504 & 440506 & 440850 & 440877 \\
\hline Northing, m & 4847063 & 4847604 & 4847604 & 4847592 & 4846863 & 4846825 \\
\hline Elevation, $\mathbf{m}$ & 877 & 893 & 929 & 947 & 929 & 947 \\
\hline $\begin{array}{l}\text { USGS Quad } \\
\text { Name }\end{array}$ & Namorf & Namorf & Namorf & Namorf & Namorf & Namorf \\
\hline Unit name & $\begin{array}{l}\text { Hunter Creek } \\
\text { Basalt }\end{array}$ & $\begin{array}{l}\text { Hunter Creek } \\
\text { Basalt }\end{array}$ & $\begin{array}{l}\text { Hunter Creek } \\
\text { Basalt }\end{array}$ & $\begin{array}{l}\text { Hunter Creek } \\
\text { Basalt }\end{array}$ & $\begin{array}{l}\text { Hunter Creek } \\
\text { Basalt }\end{array}$ & $\begin{array}{c}\text { Hunter Creek } \\
\text { Basalt }\end{array}$ \\
\hline \multicolumn{7}{|c|}{$X R F$, normalized $w t . \%$} \\
\hline $\mathrm{SiO}_{2}$ & 54.21 & 55.40 & 55.64 & 55.24 & 55.34 & 56.06 \\
\hline $\mathrm{TiO}_{2}$ & 2.39 & 2.34 & 2.21 & 2.34 & 2.35 & 2.31 \\
\hline $\mathrm{Al}_{2} \mathbf{O}_{3}$ & 13.68 & 13.46 & 13.44 & 13.44 & 13.57 & 13.63 \\
\hline $\mathrm{FeO}^{*}$ & 13.62 & 13.04 & 13.89 & 13.31 & 12.65 & 12.75 \\
\hline Mno & 0.22 & 0.21 & 0.20 & 0.21 & 0.22 & 0.17 \\
\hline Mg0 & 3.61 & 3.35 & 3.45 & 3.32 & 3.24 & 3.05 \\
\hline $\mathrm{CaO}$ & 7.27 & 7.04 & 6.69 & 7.04 & 7.08 & 6.33 \\
\hline $\mathrm{Na}_{2} \mathrm{O}$ & 3.03 & 2.71 & 3.01 & 2.71 & 3.12 & 3.41 \\
\hline $\mathbf{K}_{2} \mathbf{O}$ & 1.50 & 1.98 & 0.90 & 1.93 & 1.98 & 1.82 \\
\hline $\mathbf{P}_{2} \mathbf{O}_{5}$ & 0.46 & 0.47 & 0.58 & 0.46 & 0.45 & 0.46 \\
\hline \multicolumn{7}{|l|}{$X R F, p p m$} \\
\hline $\mathbf{N i}$ & 6 & 5 & 6 & 6 & 2 & 2 \\
\hline $\mathrm{Cr}$ & 7 & 7 & 8 & 7 & 13 & 6 \\
\hline Sc & 32 & 31 & 28 & 32 & 32 & 29 \\
\hline $\mathbf{V}$ & 371 & 361 & 324 & 363 & 362 & 349 \\
\hline $\mathbf{B a}$ & 683 & 724 & 653 & 736 & 754 & 756 \\
\hline $\mathbf{R b}$ & 40 & 49 & 15 & 49 & 53 & 53 \\
\hline $\mathrm{Sr}$ & 327 & 309 & 292 & 313 & 325 & 319 \\
\hline $\mathrm{Zr}$ & 223 & 217 & 193 & 220 & 219 & 212 \\
\hline $\mathbf{Y}$ & 43 & 42 & 53 & 45 & 42 & 41 \\
\hline Nb & 15.7 & 15.2 & 13.2 & 14.9 & 16.3 & 15.2 \\
\hline Ga & 22 & 21 & 21 & 22 & 22 & 21 \\
\hline $\mathrm{Cu}$ & 14 & 12 & 18 & 13 & 14 & 11 \\
\hline $\mathbf{Z n}$ & 145 & 142 & 124 & 144 & 143 & 139 \\
\hline $\mathbf{P b}$ & 9 & 8 & 7 & 9 & 8 & 8 \\
\hline $\mathbf{L a}$ & 32 & 30 & 30 & 26 & 31 & 26 \\
\hline $\mathrm{Ce}$ & 66 & 61 & 57 & 62 & 65 & 64 \\
\hline Th & 7 & 6 & 5 & 6 & 7 & 7 \\
\hline Nd & 35 & 32 & 31 & 31 & 35 & 33 \\
\hline $\mathbf{U}$ & 2 & 1 & 3 & 1 & 3 & 1 \\
\hline
\end{tabular}


Table 18: XRF major and trace element compositions of Hunter Creek Basalt samples. Sample locations are given in North American Datum 1983, Universal Transverse Mercator (UTM), Zone 11N.

\begin{tabular}{ccccccc}
\hline \hline Sample ID & BW_14_21 & BW_14_23 & BW_14_46B & BW_14_50 & BW_14_53 & BW_15_04 \\
Easting, m & 440851 & 440884 & 439006 & 437544 & 437555 & 437155 \\
Northing, m & 4846855 & 4846823 & 4864889 & 4864960 & 4859523 & 4879639 \\
Elevation, m & 926 & 955 & 1073 & 1118 & 1346 & 1175 \\
$\begin{array}{c}\text { USGS Quad } \\
\text { Name }\end{array}$ & Namorf & Namorf & $\begin{array}{c}\text { Little Black } \\
\text { Canyon }\end{array}$ & $\begin{array}{c}\text { Little Black } \\
\text { Canyon }\end{array}$ & $\begin{array}{c}\text { Little Black } \\
\text { Canyon }\end{array}$ & Log Creek \\
& & & &
\end{tabular}

Unit name Hunter Creek Hunter Creek Hunter Creek Hunter Creek Hunter Creek Hunter Creek $\begin{array}{llll}\text { Basalt Basalt } & \text { Basalt Basalt }\end{array}$

XRF, normalized wt.\%

\begin{tabular}{|c|c|c|c|c|c|c|}
\hline $\mathrm{SiO}_{2}$ & 55.39 & 56.49 & 55.75 & 55.75 & 55.84 & 56.73 \\
\hline $\mathrm{TiO}_{2}$ & 2.37 & 2.34 & 2.37 & 2.37 & 2.38 & 2.37 \\
\hline $\mathrm{Al}_{2} \mathrm{O}_{3}$ & 13.55 & 13.54 & 13.65 & 13.54 & 13.54 & 13.90 \\
\hline FeO* & 12.60 & 12.49 & 12.27 & 12.47 & 12.49 & 11.34 \\
\hline MnO & 0.21 & 0.20 & 0.20 & 0.21 & 0.20 & 0.20 \\
\hline MgO & 3.19 & 2.77 & 3.22 & 3.14 & 3.20 & 3.04 \\
\hline $\mathrm{CaO}$ & 7.11 & 6.19 & 6.95 & 7.00 & 6.92 & 6.85 \\
\hline $\mathrm{Na}_{2} \mathrm{O}$ & 2.95 & 3.53 & 3.04 & 3.05 & 3.06 & 3.12 \\
\hline $\mathrm{K}_{2} \mathbf{O}$ & 2.19 & 1.96 & 2.10 & 2.00 & 1.92 & 1.98 \\
\hline $\mathbf{P}_{2} \mathbf{O}_{5}$ & 0.45 & 0.50 & 0.46 & 0.46 & 0.46 & 0.47 \\
\hline \multicolumn{7}{|l|}{$X R F, p p m$} \\
\hline $\mathrm{Ni}$ & 4 & 1 & 8 & 7 & 7 & 8 \\
\hline $\mathrm{Cr}$ & 7 & 0 & 6 & 7 & 6 & 2 \\
\hline Sc & 32 & 29 & 32 & 31 & 30 & 32 \\
\hline V & 371 & 302 & 367 & 360 & 359 & 354 \\
\hline Ba & 739 & 820 & 847 & 861 & 917 & 1294 \\
\hline $\mathbf{R b}$ & 55 & 56 & 51 & 52 & 52 & 51 \\
\hline $\mathrm{Sr}$ & 328 & 321 & 331 & 326 & 335 & 358 \\
\hline $\mathbf{Z r}$ & 221 & 238 & 224 & 221 & 225 & 211 \\
\hline $\mathbf{Y}$ & 43 & 45 & 42 & 42 & 44 & 42 \\
\hline Nb & 16.6 & 16.9 & 16.1 & 16.3 & 15.5 & 14.5 \\
\hline Ga & 23 & 22 & 23 & 22 & 22 & 22 \\
\hline $\mathrm{Cu}$ & 11 & 9 & 11 & 13 & 11 & 12 \\
\hline $\mathbf{Z n}$ & 144 & 144 & 147 & 145 & 145 & 145 \\
\hline $\mathbf{P b}$ & 9 & 11 & 8 & 8 & 9 & 9 \\
\hline La & 30 & 28 & 30 & 29 & 31 & 28 \\
\hline $\mathrm{Ce}$ & 61 & 67 & 61 & 68 & 64 & 66 \\
\hline Th & 6 & 7 & 7 & 6 & 7 & 6 \\
\hline Nd & 31 & 35 & 31 & 34 & 33 & 33 \\
\hline $\mathbf{U}$ & 3 & 4 & 3 & 2 & 3 & 2 \\
\hline
\end{tabular}


Table 19: XRF major and trace element compositions of lower Littlefield Rhyolite samples. Sample locations are given in North American Datum 1983, Universal Transverse Mercator (UTM), Zone 11N.

\begin{tabular}{|c|c|c|c|c|c|c|}
\hline Sample ID & BW_13_02 & BW_13_04 & BW_13_08 & BW_14_01 & BW_14_05 & BW_14_19 \\
\hline Easting, m & 441254 & 443097 & 440148 & 440787 & 440772 & 440827 \\
\hline Northing, m & 4848002 & 4848422 & 4847159 & 4846920 & 4846870 & 4846862 \\
\hline Elevation, $\mathbf{m}$ & 864 & 799 & 822 & 834 & 877 & 917 \\
\hline $\begin{array}{l}\text { USGS Quad } \\
\text { Name }\end{array}$ & Namorf & Namorf & Namorf & Namorf & Namorf & Namorf \\
\hline Unit name & $\begin{array}{l}\text { lower } \\
\text { Littlefield } \\
\text { Rhyolite }\end{array}$ & $\begin{array}{l}\text { lower } \\
\text { Littlefield } \\
\text { Rhyolite }\end{array}$ & $\begin{array}{c}\text { lower } \\
\text { Littlefield } \\
\text { Rhyolite }\end{array}$ & $\begin{array}{l}\text { lower } \\
\text { Littlefield } \\
\text { Rhyolite }\end{array}$ & $\begin{array}{c}\text { lower } \\
\text { Littlefield } \\
\text { Rhyolite }\end{array}$ & $\begin{array}{c}\text { lower } \\
\text { Littlefield } \\
\text { Rhyolite }\end{array}$ \\
\hline \multicolumn{7}{|c|}{$X R F$, normalized wt.\% } \\
\hline $\mathrm{SiO}_{2}$ & 72.24 & 72.16 & 72.11 & 72.61 & 72.93 & 71.98 \\
\hline $\mathrm{TiO}_{2}$ & 0.70 & 0.70 & 0.70 & 0.71 & 0.72 & 0.70 \\
\hline $\mathrm{Al}_{2} \mathbf{O}_{3}$ & 12.60 & 12.66 & 12.57 & 12.57 & 12.64 & 12.64 \\
\hline $\mathrm{FeO}^{*}$ & 4.08 & 4.09 & 4.02 & 4.23 & 3.95 & 4.15 \\
\hline Mno & 0.09 & 0.11 & 0.09 & 0.08 & 0.06 & 0.09 \\
\hline MgO & 0.45 & 0.54 & 0.46 & 0.43 & 0.39 & 0.47 \\
\hline $\mathrm{CaO}$ & 1.76 & 1.77 & 1.79 & 1.40 & 1.27 & 1.78 \\
\hline $\mathrm{Na}_{2} \mathrm{O}$ & 2.55 & 2.57 & 2.79 & 3.59 & 3.60 & 2.47 \\
\hline $\mathbf{K}_{2} \mathbf{O}$ & 5.39 & 5.26 & 5.34 & 4.23 & 4.30 & 5.58 \\
\hline $\mathbf{P}_{2} \mathbf{O}_{5}$ & 0.14 & 0.14 & 0.14 & 0.14 & 0.14 & 0.14 \\
\hline \multicolumn{7}{|l|}{$X R F, p p m$} \\
\hline $\mathbf{N i}$ & 1 & 0 & 1 & 0 & 0 & 0 \\
\hline $\mathrm{Cr}$ & 3 & 4 & 2 & 13 & 4 & 2 \\
\hline Sc & 12 & 12 & 12 & 12 & 12 & 11 \\
\hline $\mathbf{V}$ & 15 & 15 & 14 & 14 & 15 & 17 \\
\hline $\mathbf{B a}$ & 1287 & 1265 & 1285 & 1282 & 1298 & 1267 \\
\hline $\mathbf{R b}$ & 157 & 165 & 153 & 140 & 143 & 153 \\
\hline $\mathbf{S r}$ & 168 & 169 & 169 & 165 & 159 & 171 \\
\hline $\mathbf{Z r}$ & 296 & 302 & 299 & 302 & 307 & 298 \\
\hline $\mathbf{Y}$ & 41 & 42 & 42 & 42 & 41 & 41 \\
\hline $\mathbf{N b}$ & 18.9 & 18.6 & 19.1 & 19.8 & 19.6 & 19.3 \\
\hline Ga & 19 & 18 & 18 & 18 & 18 & 18 \\
\hline $\mathrm{Cu}$ & 5 & 5 & 4 & 6 & 4 & 3 \\
\hline $\mathbf{Z n}$ & 91 & 90 & 90 & 92 & 99 & 90 \\
\hline $\mathbf{P b}$ & 24 & 25 & 25 & 24 & 25 & 24 \\
\hline La & 44 & 48 & 46 & 43 & 44 & 41 \\
\hline $\mathrm{Ce}$ & 84 & 89 & 88 & 90 & 93 & 88 \\
\hline Th & 17 & 17 & 16 & 17 & 17 & 17 \\
\hline Nd & 40 & 40 & 38 & 41 & 41 & 40 \\
\hline $\mathbf{U}$ & 6 & 8 & 6 & 4 & 4 & 6 \\
\hline
\end{tabular}


Table 20: XRF major and trace element compositions of lower Littlefield Rhyolite samples. Sample locations are given in North American Datum 1983, Universal Transverse Mercator (UTM), Zone 11N.

\begin{tabular}{|c|c|c|c|c|c|c|c|}
\hline Sample ID & BW_14_26 & 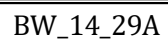 & 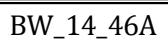 & "BW_14_48 & "BW_14_54 & PW_14_55 & BW_14_56 \\
\hline Easting, m & 440383 & 439108 & 439006 & 438927 & 438528 & 438570 & 439144 \\
\hline Northing, $\mathrm{m}$ & 4847584 & 4846556 & 4864889 & 4865122 & 4862120 & 4862087 & 4861016 \\
\hline Elevation, m & 818 & 844 & 1073 & 1065 & 1202 & 1193 & 1202 \\
\hline $\begin{array}{l}\text { USGS Quad } \\
\text { Name }\end{array}$ & Namorf & South Mtn & $\begin{array}{l}\text { Little Black } \\
\text { Canyon }\end{array}$ & $\begin{array}{l}\text { Little Black } \\
\text { Canyon }\end{array}$ & $\begin{array}{l}\text { Little Black } \\
\text { Canyon }\end{array}$ & $\begin{array}{l}\text { Little Black } \\
\text { Canyon }\end{array}$ & $\begin{array}{l}\text { Little Black } \\
\text { Canyon }\end{array}$ \\
\hline Unit name & $\begin{array}{l}\text { lower } \\
\text { Littlefield } \\
\text { Rhyolite }\end{array}$ & $\begin{array}{l}\text { lower } \\
\text { Littlefield } \\
\text { Rhyolite }\end{array}$ & $\begin{array}{l}\text { lower } \\
\text { Littlefield } \\
\text { Rhyolite }\end{array}$ & $\begin{array}{l}\text { lower } \\
\text { Littlefield } \\
\text { Rhyolite }\end{array}$ & $\begin{array}{l}\text { lower } \\
\text { Littlefield } \\
\text { Rhyolite }\end{array}$ & $\begin{array}{l}\text { lower } \\
\text { Littlefield } \\
\text { Rhyolite }\end{array}$ & $\begin{array}{c}\text { lower } \\
\text { Littlefield } \\
\text { Rhyolite }\end{array}$ \\
\hline \multicolumn{8}{|c|}{$X R F$, normalized wt.\% } \\
\hline $\mathrm{SiO}_{2}$ & 72.05 & 72.50 & 72.37 & 72.35 & 72.56 & 72.17 & 72.35 \\
\hline $\mathrm{TiO}_{2}$ & 0.70 & 0.70 & 0.70 & 0.72 & 0.71 & 0.70 & 0.72 \\
\hline $\mathrm{Al}_{2} \mathrm{O}_{3}$ & 12.66 & 12.58 & 12.61 & 12.59 & 12.60 & 12.70 & 12.70 \\
\hline $\mathrm{FeO}^{*}$ & 4.15 & 3.87 & 4.01 & 3.98 & 3.82 & 3.96 & 3.76 \\
\hline Mno & 0.09 & 0.08 & 0.08 & 0.09 & 0.08 & 0.08 & 0.08 \\
\hline MgO & 0.46 & 0.42 & 0.43 & 0.43 & 0.39 & 0.43 & 0.41 \\
\hline $\mathrm{CaO}$ & 1.81 & 1.67 & 1.66 & 1.69 & 1.59 & 1.70 & 1.66 \\
\hline $\mathrm{Na}_{2} \mathrm{O}$ & 2.77 & 2.75 & 3.00 & 2.77 & 2.57 & 2.50 & 2.48 \\
\hline $\mathbf{K}_{2} \mathbf{O}$ & 5.17 & 5.30 & 4.98 & 5.24 & 5.55 & 5.61 & 5.70 \\
\hline $\mathbf{P}_{2} \mathbf{O}_{5}$ & 0.14 & 0.13 & 0.14 & 0.14 & 0.14 & 0.14 & 0.14 \\
\hline \multicolumn{8}{|l|}{$X R F, p p m$} \\
\hline $\mathbf{N i}$ & 0 & 1 & 1 & 1 & 2 & 1 & 3 \\
\hline $\mathrm{Cr}$ & 2 & 2 & 2 & 2 & 1 & 2 & 2 \\
\hline Sc & 12 & 11 & 12 & 11 & 12 & 12 & 13 \\
\hline $\mathbf{v}$ & 15 & 18 & 15 & 18 & 19 & 14 & 14 \\
\hline Ba & 1262 & 1289 & 1307 & 1319 & 1298 & 1289 & 1301 \\
\hline $\mathbf{R b}$ & 150 & 154 & 143 & 145 & 146 & 147 & 148 \\
\hline $\mathrm{Sr}$ & 174 & 163 & 169 & 168 & 162 & 171 & 172 \\
\hline $\mathbf{Z r}$ & 295 & 302 & 301 & 300 & 301 & 296 & 298 \\
\hline $\mathbf{Y}$ & 42 & 42 & 42 & 42 & 42 & 41 & 40 \\
\hline $\mathbf{N b}$ & 18.4 & 19.1 & 19.2 & 19.1 & 19.2 & 19.7 & 18.9 \\
\hline Ga & 18 & 18 & 18 & 18 & 18 & 19 & 19 \\
\hline $\mathrm{Cu}$ & 2 & 4 & 2 & 1 & 1 & 1 & 1 \\
\hline $\mathbf{Z n}$ & 87 & 90 & 90 & 92 & 89 & 89 & 89 \\
\hline $\mathbf{P b}$ & 24 & 24 & 25 & 25 & 25 & 25 & 24 \\
\hline La & 43 & 45 & 46 & 47 & 46 & 45 & 47 \\
\hline $\mathrm{Ce}$ & 90 & 88 & 85 & 87 & 89 & 87 & 86 \\
\hline Th & 16 & 17 & 17 & 16 & 17 & 17 & 17 \\
\hline Nd & 38 & 40 & 38 & 39 & 40 & 41 & 39 \\
\hline $\mathbf{U}$ & 5 & 6 & 5 & 4 & 6 & 5 & 6 \\
\hline
\end{tabular}


Table 21: XRF major and trace element compositions of upper Littlefield Rhyolite samples. Sample locations are given in North American Datum 1983, Universal Transverse Mercator (UTM), Zone 11N.

\begin{tabular}{|c|c|c|c|c|c|c|}
\hline Sample ID & BW_14_16 & BW_14_36 & BW_14_39A & BW_14_40 & BW_14_42A & BW_14_67 \\
\hline Easting, m & 440982 & 432950 & 433135 & 442439 & 442360 & 440948 \\
\hline Northing, m & 4846770 & 4825940 & 4826068 & 4856631 & 4856755 & 4846821 \\
\hline Elevation, $\mathbf{m}$ & 1018 & 1253 & 1266 & 1010 & 1045 & 973 \\
\hline $\begin{array}{l}\text { USGS Quad } \\
\text { Name }\end{array}$ & Namorf & Alder Creek & Alder Creek & Namorf & Namorf & Namorf \\
\hline Unit name & $\begin{array}{c}\text { upper } \\
\text { Littlefield } \\
\text { Rhyolite }\end{array}$ & $\begin{array}{c}\text { upper } \\
\text { Littlefield } \\
\text { Rhyolite }\end{array}$ & $\begin{array}{c}\text { upper } \\
\text { Littlefield } \\
\text { Rhyolite }\end{array}$ & $\begin{array}{c}\text { upper } \\
\text { Littlefield } \\
\text { Rhyolite }\end{array}$ & $\begin{array}{c}\text { upper } \\
\text { Littlefield } \\
\text { Rhyolite }\end{array}$ & $\begin{array}{c}\text { upper } \\
\text { Littlefield } \\
\text { Rhyolite }\end{array}$ \\
\hline \multicolumn{7}{|c|}{ XRF, normalized wt.\% } \\
\hline $\mathrm{SiO}_{2}$ & 71.79 & 72.24 & 72.52 & 71.30 & 71.88 & 72.30 \\
\hline $\mathrm{TiO}_{2}$ & 0.41 & 0.36 & 0.40 & 0.41 & 0.41 & 0.41 \\
\hline $\mathrm{Al}_{2} \mathbf{O}_{3}$ & 12.49 & 12.37 & 12.68 & 12.35 & 12.45 & 12.86 \\
\hline $\mathrm{FeO}^{*}$ & 5.63 & 4.81 & 4.32 & 5.49 & 5.31 & 4.24 \\
\hline Mno & 0.08 & 0.09 & 0.14 & 0.14 & 0.14 & 0.10 \\
\hline MgO & 0.25 & 0.09 & 0.07 & 0.09 & 0.32 & 0.10 \\
\hline $\mathrm{CaO}$ & 0.98 & 1.39 & 1.25 & 1.84 & 1.10 & 1.57 \\
\hline $\mathrm{Na}_{2} \mathrm{O}$ & 4.21 & 3.33 & 4.37 & 3.48 & 4.23 & 2.91 \\
\hline $\mathbf{K}_{2} \mathbf{O}$ & 4.09 & 5.28 & 4.20 & 4.84 & 4.10 & 5.46 \\
\hline $\mathbf{P}_{2} \mathbf{O}_{5}$ & 0.06 & 0.04 & 0.06 & 0.05 & 0.06 & 0.05 \\
\hline \multicolumn{7}{|l|}{$X R F, p p m$} \\
\hline $\mathbf{N i}$ & 0 & 1 & 2 & 0 & 0 & 3 \\
\hline $\mathrm{Cr}$ & 3 & 1 & 0 & 1 & 2 & 4 \\
\hline Sc & 8 & 6 & 7 & 7 & 7 & 6 \\
\hline $\mathbf{v}$ & 1 & 3 & 6 & 2 & 4 & 5 \\
\hline $\mathbf{B a}$ & 1693 & 1736 & 1854 & 1706 & 1676 & 1695 \\
\hline $\mathbf{R b}$ & 116 & 127 & 121 & 129 & 115 & 121 \\
\hline $\mathrm{Sr}$ & 139 & 121 & 137 & 139 & 136 & 138 \\
\hline $\mathbf{Z r}$ & 552 & 564 & 572 & 544 & 551 & 542 \\
\hline $\mathbf{Y}$ & 81 & 91 & 93 & 89 & 91 & 83 \\
\hline $\mathbf{N b}$ & 37.3 & 37.4 & 38.2 & 35.8 & 36.4 & 35.3 \\
\hline Ga & 25 & 24 & 25 & 23 & 24 & 24 \\
\hline $\mathrm{Cu}$ & 3 & 2 & 4 & 3 & 4 & 2 \\
\hline $\mathbf{Z n}$ & 158 & 159 & 168 & 170 & 170 & 151 \\
\hline $\mathbf{P b}$ & 19 & 20 & 21 & 20 & 22 & 19 \\
\hline La & 57 & 64 & 65 & 58 & 65 & 62 \\
\hline $\mathrm{Ce}$ & 116 & 129 & 132 & 130 & 129 & 125 \\
\hline Th & 14 & 14 & 15 & 14 & 15 & 14 \\
\hline Nd & 59 & 68 & 67 & 64 & 65 & 62 \\
\hline $\mathbf{U}$ & 3 & 4 & 5 & 5 & 5 & 3 \\
\hline
\end{tabular}




\section{Inductively Coupled Plasma-Mass Spectrometry (ICP-MS) Chemical Data}

Table 22: ICP-MS trace element compositions of icelandite of Alder Creek Canyon and basalt of Malheur Gorge samples. Icelandite of Alder Creek Canyon is stratigraphically equivalent to Hunter Creek Basalt.

\begin{tabular}{cccccc}
\hline \hline Sample ID & BW_14_37A & BW_14_37B & BW_15_31 & BW_15_36 & BW_15_21 \\
Unit name & $\begin{array}{c}\text { Alder Creek } \\
\text { icelandite }\end{array}$ & $\begin{array}{c}\text { Alder Creek } \\
\text { icelandite }\end{array}$ & Birch Creek & Birch Creek & $\begin{array}{c}\text { Upper Pole } \\
\text { Creek }\end{array}$ \\
ICP-MS, ppm & & & & & \\
\hline La & 46.65 & 46.34 & 24.30 & 15.47 & 29.70 \\
Ce & 94.45 & 96.52 & 52.92 & 82.90 & 64.01 \\
Pr & 12.54 & 12.38 & 7.00 & 3.32 & 8.58 \\
Nd & 51.72 & 51.07 & 30.23 & 12.13 & 37.29 \\
Sm & 12.06 & 11.96 & 7.58 & 2.73 & 9.16 \\
Eu & 3.38 & 3.45 & 2.36 & 1.16 & 2.75 \\
Gd & 12.26 & 11.64 & 7.69 & 2.88 & 9.60 \\
Tb & 2.03 & 1.95 & 1.28 & 0.62 & 1.57 \\
Dy & 12.43 & 11.99 & 7.68 & 4.71 & 9.57 \\
Ho & 2.60 & 2.45 & 1.56 & 1.15 & 1.92 \\
$\mathbf{E r}$ & 7.04 & 6.56 & 4.17 & 3.68 & 5.10 \\
Tm & 1.01 & 0.97 & 0.59 & 0.67 & 0.72 \\
Yb & 6.24 & 5.99 & 3.58 & 4.71 & 4.54 \\
Lu & 0.97 & 0.97 & 0.57 & 0.80 & 0.71 \\
$\mathbf{B a}$ & 1204 & 1199 & 691 & 1150 & 839 \\
Th & 9.76 & 9.83 & 4.80 & 6.11 & 5.45 \\
$\mathbf{N b}$ & 22.77 & 23.38 & 13.00 & 17.83 & 15.42 \\
$\mathbf{Y}$ & 67.67 & 61.63 & 38.50 & 28.75 & 48.78 \\
$\mathbf{H f}$ & 9.20 & 9.12 & 5.68 & 9.36 & 6.71 \\
Ta & 1.43 & 1.48 & 0.89 & 1.11 & 1.04 \\
$\mathbf{U}$ & 2.80 & 2.79 & 1.44 & 2.44 & 1.84 \\
$\mathbf{P b}$ & 14.31 & 14.49 & 8.16 & 14.01 & 9.19 \\
$\mathbf{R b}$ & 79.52 & 78.69 & 41.36 & 53.00 & 59.31 \\
$\mathbf{C s}$ & 2.57 & 1.17 & 2.24 & 0.82 & 2.99 \\
$\mathbf{S r}$ & 286 & 280 & 349 & 38 & 346 \\
$\mathbf{S c}$ & 23.08 & 23.54 & 30.93 & 3.89 & 29.03 \\
$\mathbf{Z r}$ & 349 & 356 & 214 & 347 & 250 \\
\hline
\end{tabular}


Table 23: ICP-MS trace element compositions of tuffaceous samples.

\begin{tabular}{|c|c|c|c|c|c|}
\hline Sample ID & "BW_14_14 & "BW_14_38 & "BW_14_45 & "BW_14_52 & "BW_14_12 \\
\hline Unit name & $\begin{array}{c}\text { Dacite welded } \\
\text { tuff }\end{array}$ & $\begin{array}{c}\text { Dacite welded } \\
\text { tuff }\end{array}$ & $\begin{array}{c}\text { Dinner Creek } \\
\text { Tuff }\end{array}$ & $\begin{array}{l}\text { Welded tuff, } \\
\text { altered }\end{array}$ & Epiclastic tuff \\
\hline \multicolumn{6}{|l|}{ ICP-MS, ppm } \\
\hline La & 31.87 & 34.62 & 43.14 & 30.58 & 29.57 \\
\hline $\mathrm{Ce}$ & 62.46 & 67.11 & 91.13 & 62.82 & 63.08 \\
\hline Pr & 8.72 & 8.75 & 11.54 & 8.07 & 8.02 \\
\hline $\mathbf{N d}$ & 35.99 & 35.73 & 46.17 & 34.26 & 32.51 \\
\hline Sm & 8.83 & 8.39 & 10.99 & 8.09 & 8.62 \\
\hline $\mathbf{E u}$ & 2.43 & 1.97 & 1.62 & 2.37 & 0.35 \\
\hline Gd & 8.85 & 8.94 & 11.21 & 8.22 & 8.76 \\
\hline $\mathbf{T b}$ & 1.54 & 1.54 & 2.14 & 1.37 & 1.66 \\
\hline Dy & 9.66 & 9.81 & 14.29 & 8.27 & 11.00 \\
\hline Ho & 2.02 & 2.10 & 3.14 & 1.69 & 2.35 \\
\hline Er & 5.59 & 5.93 & 9.23 & 4.53 & 7.06 \\
\hline Tm & 0.82 & 0.87 & 1.45 & 0.65 & 1.09 \\
\hline $\mathbf{Y b}$ & 5.11 & 5.33 & 9.44 & 3.96 & 7.26 \\
\hline $\mathbf{L u}$ & 0.79 & 0.84 & 1.55 & 0.62 & 1.15 \\
\hline $\mathbf{B a}$ & 464 & 791 & 1304 & 910 & 46 \\
\hline Th & 6.61 & 6.59 & 7.76 & 6.19 & 14.79 \\
\hline $\mathrm{Nb}$ & 17.13 & 16.41 & 23.43 & 14.95 & 19.30 \\
\hline $\mathbf{Y}$ & 55.09 & 58.61 & 81.64 & 42.88 & 61.04 \\
\hline Hf & 7.01 & 7.35 & 11.69 & 5.78 & 9.04 \\
\hline Ta & 1.10 & 1.06 & 1.43 & 1.01 & 1.47 \\
\hline $\mathbf{U}$ & 3.98 & 1.60 & 3.17 & 1.74 & 4.39 \\
\hline $\mathbf{P b}$ & 11.09 & 13.79 & 17.22 & 9.08 & 25.08 \\
\hline $\mathbf{R b}$ & 53.17 & 47.67 & 81.60 & 50.11 & 119.16 \\
\hline Cs & 4.22 & 2.51 & 2.97 & 1.52 & 5.00 \\
\hline $\mathrm{Sr}$ & 143 & 249 & 39 & 341 & 24 \\
\hline Sc & 22.55 & 19.08 & 4.12 & 31.82 & 2.83 \\
\hline $\mathrm{Zr}$ & 265 & 277 & 442 & 221 & 243 \\
\hline
\end{tabular}


Table 24: ICP-MS trace element compositions of Hunter Creek Basalt samples. Samples BW13-05, BW-13-09, and BW-13-12 are agglutinated spatter. Sample BW-13-10 is scoria, and is considered to be a poor quality sample. All remaining Hunter Creek Basalt samples are lavas.

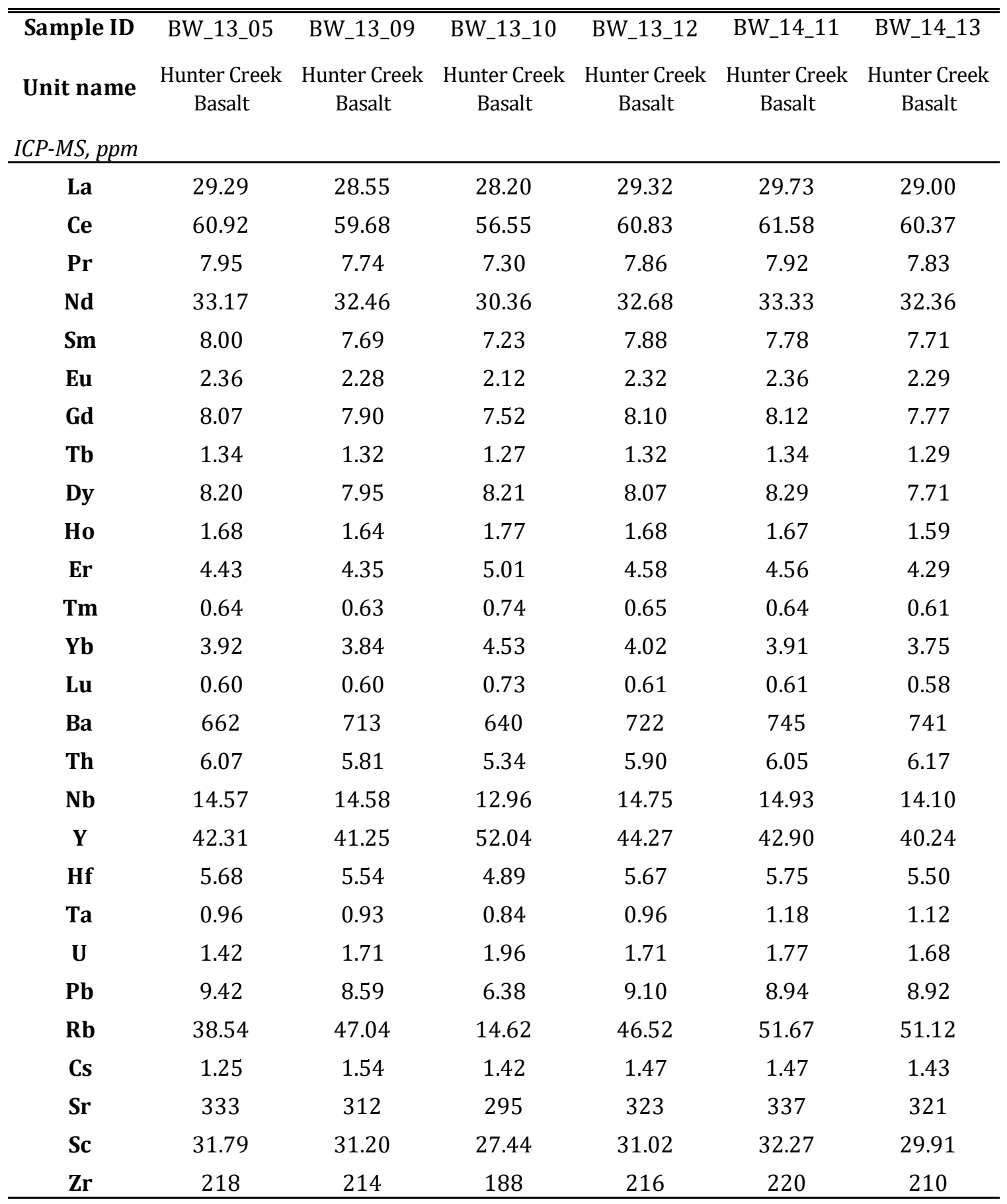


Table 25: ICP-MS trace element compositions of Hunter Creek Basalt samples.

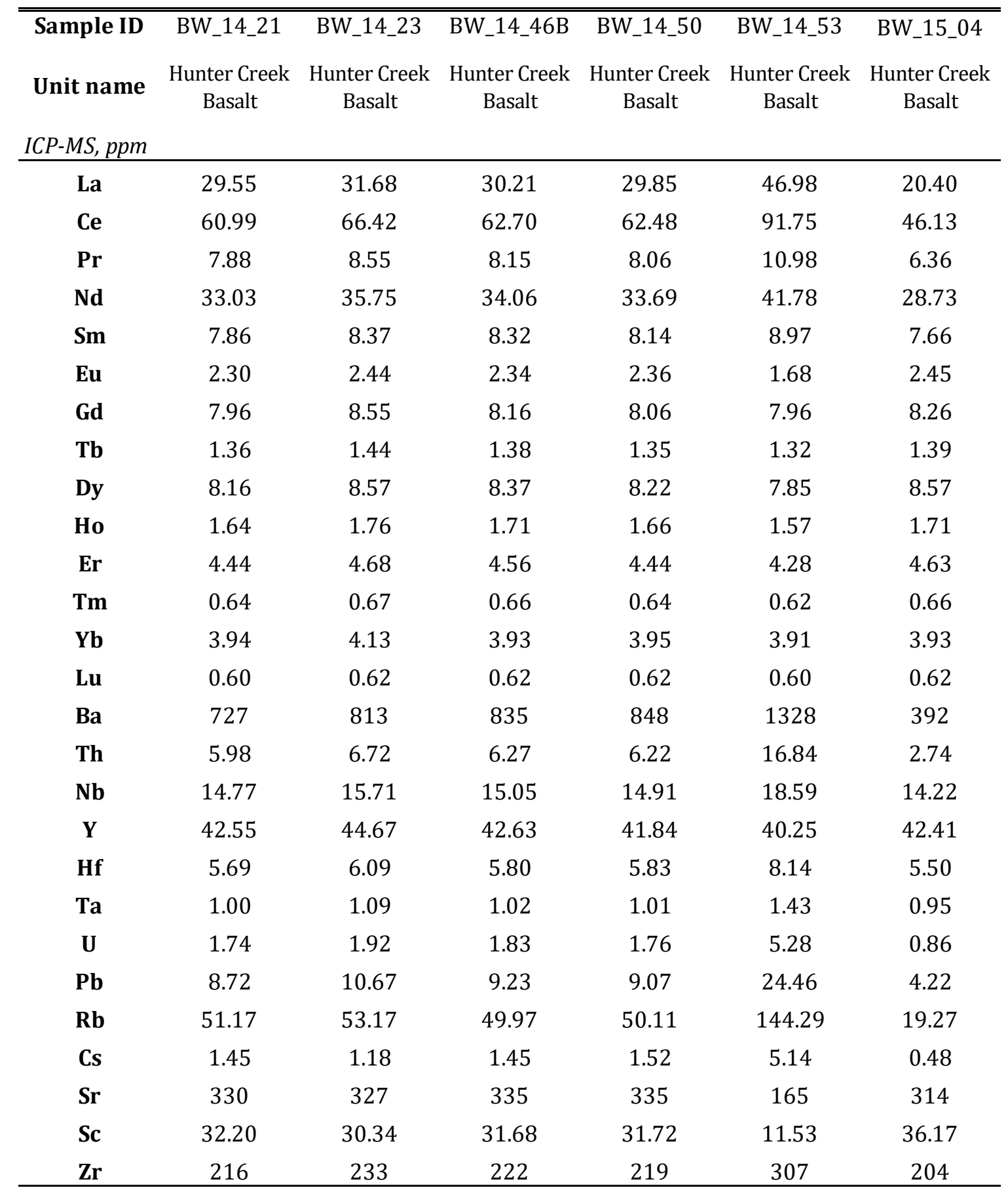


Table 26: ICP-MS trace element compositions of lower Littlefield Rhyolite samples.

\begin{tabular}{|c|c|c|c|c|c|c|}
\hline $\begin{array}{l}\text { Sample ID } \\
\text { Unit name } \\
I C P-M S, p p m \\
\end{array}$ & $\begin{array}{c}\text { BW_13_02 } \\
\text { lower } \\
\text { Littlefield } \\
\text { Rhyolite }\end{array}$ & $\begin{array}{c}\text { BW_13_04 } \\
\text { lower } \\
\text { Littlefield } \\
\text { Rhyolite }\end{array}$ & $\begin{array}{c}\text { BW_13_08 } \\
\text { lower } \\
\text { Littlefield } \\
\text { Rhyolite }\end{array}$ & $\begin{array}{c}\text { BW_14_01 } \\
\text { lower } \\
\text { Littlefield } \\
\text { Rhyolite }\end{array}$ & $\begin{array}{c}\text { BW_14_05 } \\
\text { lower } \\
\text { Littlefield } \\
\text { Rhyolite }\end{array}$ & $\begin{array}{c}\text { BW_14_19 } \\
\text { lower } \\
\text { Littlefield } \\
\text { Rhyolite }\end{array}$ \\
\hline La & 45.83 & 46.24 & 46.29 & 46.59 & 48.05 & 46.43 \\
\hline $\mathrm{Ce}$ & 89.67 & 90.46 & 90.74 & 91.03 & 93.64 & 90.98 \\
\hline Pr & 10.78 & 10.73 & 10.79 & 10.88 & 11.22 & 10.79 \\
\hline Nd & 40.50 & 40.94 & 40.99 & 41.46 & 42.92 & 41.43 \\
\hline Sm & 8.71 & 8.57 & 8.70 & 8.67 & 8.91 & 8.84 \\
\hline Eu & 1.69 & 1.68 & 1.68 & 1.71 & 1.69 & 1.72 \\
\hline Gd & 7.79 & 7.89 & 7.80 & 7.88 & 7.95 & 7.74 \\
\hline $\mathbf{T b}$ & 1.26 & 1.27 & 1.29 & 1.29 & 1.30 & 1.28 \\
\hline Dy & 7.72 & 7.72 & 7.72 & 7.65 & 7.85 & 7.76 \\
\hline Ho & 1.55 & 1.60 & 1.55 & 1.56 & 1.58 & 1.58 \\
\hline Er & 4.21 & 4.28 & 4.24 & 4.21 & 4.25 & 4.24 \\
\hline Tm & 0.61 & 0.62 & 0.61 & 0.61 & 0.64 & 0.61 \\
\hline $\mathbf{Y b}$ & 3.88 & 3.96 & 3.89 & 3.83 & 3.97 & 3.94 \\
\hline Lu & 0.59 & 0.59 & 0.60 & 0.61 & 0.62 & 0.61 \\
\hline Ba & 1290 & 1263 & 1301 & 1306 & 1313 & 1289 \\
\hline Th & 16.54 & 16.70 & 16.55 & 16.80 & 17.29 & 16.43 \\
\hline $\mathrm{Nb}$ & 18.30 & 18.52 & 18.29 & 18.59 & 19.06 & 18.39 \\
\hline $\mathbf{Y}$ & 39.85 & 40.87 & 40.26 & 40.30 & 39.61 & 40.85 \\
\hline Hf & 7.94 & 8.08 & 8.09 & 8.20 & 8.31 & 8.03 \\
\hline Ta & 1.36 & 1.37 & 1.36 & 1.51 & 1.50 & 1.44 \\
\hline $\mathbf{U}$ & 5.33 & 5.27 & 5.31 & 5.38 & 5.51 & 5.33 \\
\hline $\mathbf{P b}$ & 23.93 & 24.19 & 24.12 & 24.22 & 24.63 & 23.79 \\
\hline $\mathbf{R b}$ & 152.27 & 161.22 & 148.78 & 137.17 & 140.87 & 150.63 \\
\hline Cs & 5.22 & 5.09 & 5.13 & 4.18 & 4.13 & 5.17 \\
\hline $\mathrm{Sr}$ & 171 & 173 & 172 & 170 & 163 & 177 \\
\hline Sc & 11.97 & 11.88 & 11.50 & 11.78 & 12.22 & 11.96 \\
\hline $\mathrm{Zr}$ & 299 & 304 & 299 & 303 & 311 & 301 \\
\hline
\end{tabular}


Table 27: ICP-MS trace element compositions of lower Littlefield Rhyolite samples.

\begin{tabular}{|c|c|c|c|c|c|c|c|}
\hline $\begin{array}{l}\text { Sample ID } \\
\text { Unit name }\end{array}$ & $\begin{array}{c}\text { BW_14_26 } \\
\text { lower } \\
\text { Littlefield } \\
\text { Rhyolite }\end{array}$ & $\begin{array}{c}\text { BW_14_29A } \\
\text { lower } \\
\text { Littlefield } \\
\text { Rhyolite }\end{array}$ & $\begin{array}{c}\text { BW_14_46A } \\
\text { lower } \\
\text { Littlefield } \\
\text { Rhyolite }\end{array}$ & $\begin{array}{c}\text { BW_14_48 } \\
\text { lower } \\
\text { Littlefield } \\
\text { Rhyolite }\end{array}$ & $\begin{array}{c}\text { BW_14_54 } \\
\text { lower } \\
\text { Littlefield } \\
\text { Rhyolite }\end{array}$ & $\begin{array}{c}\text { BW_14_55 } \\
\text { lower } \\
\text { Littlefield } \\
\text { Rhyolite }\end{array}$ & $\begin{array}{c}\text { BW_14_56 } \\
\text { lower } \\
\text { Littlefield } \\
\text { Rhyolite }\end{array}$ \\
\hline \multicolumn{8}{|l|}{$I C P-M S, p p m$} \\
\hline La & 45.81 & 45.84 & 47.18 & 46.54 & 46.29 & 46.50 & 62.91 \\
\hline $\mathrm{Ce}$ & 89.40 & 89.71 & 92.08 & 90.34 & 90.06 & 90.53 & 129.31 \\
\hline Pr & 10.76 & 10.66 & 10.99 & 10.86 & 10.77 & 10.75 & 16.19 \\
\hline Nd & 40.40 & 40.40 & 41.76 & 41.30 & 41.15 & 41.03 & 64.19 \\
\hline Sm & 8.81 & 8.77 & 8.88 & 8.75 & 8.81 & 8.78 & 14.86 \\
\hline Eu & 1.75 & 1.67 & 1.76 & 1.71 & 1.72 & 1.74 & 3.65 \\
\hline Gd & 7.75 & 7.81 & 7.98 & 7.90 & 7.90 & 7.78 & 14.36 \\
\hline $\mathbf{T b}$ & 1.29 & 1.26 & 1.33 & 1.29 & 1.29 & 1.27 & 2.52 \\
\hline Dy & 7.53 & 7.52 & 7.85 & 7.73 & 7.69 & 7.52 & 15.74 \\
\hline Ho & 1.53 & 1.52 & 1.59 & 1.56 & 1.54 & 1.54 & 3.29 \\
\hline Er & 4.16 & 4.20 & 4.31 & 4.27 & 4.18 & 4.18 & 9.10 \\
\hline $\mathrm{Tm}$ & 0.60 & 0.60 & 0.63 & 0.62 & 0.61 & 0.60 & 1.35 \\
\hline $\mathbf{Y b}$ & 3.78 & 3.78 & 3.92 & 3.90 & 3.84 & 3.82 & 8.40 \\
\hline Lu & 0.61 & 0.61 & 0.62 & 0.59 & 0.60 & 0.61 & 1.32 \\
\hline Ba & 1283 & 1297 & 1349 & 1342 & 1311 & 1329 & 1726 \\
\hline Th & 16.57 & 16.75 & 16.88 & 16.72 & 16.39 & 16.38 & 13.70 \\
\hline Nb & 18.15 & 18.35 & 18.66 & 18.38 & 18.24 & 18.39 & 35.42 \\
\hline $\mathbf{Y}$ & 39.45 & 39.73 & 40.70 & 40.33 & 39.76 & 39.54 & 83.36 \\
\hline Hf & 7.90 & 7.94 & 8.13 & 8.09 & 8.00 & 8.08 & 14.26 \\
\hline Ta & 1.39 & 1.41 & 1.40 & 1.42 & 1.43 & 1.40 & 2.36 \\
\hline $\mathbf{U}$ & 5.30 & 5.38 & 5.34 & 5.23 & 5.19 & 5.34 & 3.87 \\
\hline $\mathbf{P b}$ & 24.07 & 24.28 & 24.44 & 24.29 & 23.86 & 24.01 & 19.08 \\
\hline $\mathbf{R b}$ & 147.23 & 147.76 & 142.60 & 144.38 & 144.40 & 145.55 & 121.25 \\
\hline Cs & 5.17 & 5.24 & 5.08 & 5.13 & 5.08 & 5.16 & 3.20 \\
\hline $\mathrm{Sr}$ & 177 & 164 & 174 & 174 & 172 & 175 & 144 \\
\hline Sc & 11.98 & 11.43 & 12.02 & 12.13 & 11.72 & 11.98 & 6.52 \\
\hline $\mathrm{Zr}$ & 296 & 302 & 304 & 302 & 298 & 301 & 559 \\
\hline
\end{tabular}


Table 28: ICP-MS trace element compositions of upper Littlefield Rhyolite samples.

\begin{tabular}{|c|c|c|c|c|c|c|}
\hline $\begin{array}{l}\text { Sample ID } \\
\text { Unit name } \\
I C P-M S, p p m\end{array}$ & $\begin{array}{l}\text { BW_14_16 } \\
\text { upper } \\
\text { Littlefield } \\
\text { Rhyolite }\end{array}$ & $\begin{array}{c}\text { BW_14_36 } \\
\text { upper } \\
\text { Littlefield } \\
\text { Rhyolite }\end{array}$ & $\begin{array}{c}\text { BW_14_39A } \\
\text { upper } \\
\text { Littlefield } \\
\text { Rhyolite }\end{array}$ & $\begin{array}{c}\text { BW_14_40 } \\
\text { upper } \\
\text { Littlefield } \\
\text { Rhyolite }\end{array}$ & $\begin{array}{c}\text { BW_14_42A } \\
\text { upper } \\
\text { Littlefield } \\
\text { Rhyolite }\end{array}$ & $\begin{array}{c}\text { BW_14_67 } \\
\text { upper } \\
\text { Littlefield } \\
\text { Rhyolite }\end{array}$ \\
\hline La & 57.13 & 65.81 & 67.47 & 62.91 & 63.80 & 30.55 \\
\hline $\mathrm{Ce}$ & 117.24 & 132.49 & 134.13 & 130.12 & 131.50 & 63.10 \\
\hline Pr & 14.88 & 16.89 & 17.15 & 16.37 & 16.68 & 8.07 \\
\hline Nd & 59.84 & 67.23 & 69.34 & 65.66 & 66.95 & 33.57 \\
\hline Sm & 13.76 & 15.61 & 16.14 & 15.30 & 15.52 & 7.91 \\
\hline Eu & 3.68 & 3.55 & 3.73 & 3.67 & 3.76 & 2.41 \\
\hline Gd & 13.53 & 15.25 & 15.56 & 15.00 & 15.30 & 8.16 \\
\hline $\mathbf{T b}$ & 2.43 & 2.64 & 2.72 & 2.62 & 2.69 & 1.33 \\
\hline Dy & 15.37 & 16.81 & 17.00 & 16.43 & 16.74 & 8.12 \\
\hline Ho & 3.21 & 3.46 & 3.56 & 3.39 & 3.49 & 1.66 \\
\hline Er & 8.88 & 9.63 & 9.94 & 9.46 & 9.70 & 4.48 \\
\hline $\mathrm{Tm}$ & 1.31 & 1.43 & 1.46 & 1.41 & 1.44 & 0.63 \\
\hline $\mathbf{Y b}$ & 8.52 & 9.00 & 9.06 & 8.87 & 9.01 & 3.88 \\
\hline Lu & 1.32 & 1.41 & 1.41 & 1.43 & 1.42 & 0.61 \\
\hline Ba & 1721 & 1778 & 1904 & 1726 & 1709 & 1294 \\
\hline Th & 13.76 & 14.50 & 14.59 & 13.76 & 13.86 & 6.36 \\
\hline $\mathrm{Nb}$ & 35.22 & 35.94 & 37.09 & 35.16 & 35.49 & 14.51 \\
\hline $\mathbf{Y}$ & 78.17 & 88.23 & 91.30 & 86.12 & 89.02 & 41.29 \\
\hline Hf & 14.38 & 14.74 & 14.98 & 14.09 & 14.23 & 5.82 \\
\hline Ta & 2.24 & 2.25 & 2.31 & 2.19 & 2.22 & 0.99 \\
\hline $\mathbf{U}$ & 3.70 & 4.21 & 4.32 & 3.98 & 3.86 & 1.82 \\
\hline $\mathbf{P b}$ & 18.51 & 19.80 & 20.08 & 19.00 & 21.06 & 9.29 \\
\hline $\mathbf{R b}$ & 113.19 & 125.67 & 119.93 & 126.55 & 113.36 & 50.78 \\
\hline Cs & 2.07 & 3.52 & 3.49 & 3.18 & 1.91 & 1.70 \\
\hline $\mathrm{Sr}$ & 144 & 126 & 145 & 143 & 142 & 359 \\
\hline Sc & 7.09 & 5.58 & 6.70 & 7.23 & 7.45 & 30.90 \\
\hline $\mathrm{Zr}$ & 555 & 570 & 583 & 548 & 556 & 215 \\
\hline
\end{tabular}




\section{APPENDIX B: PORTABLE X-RAY FLUORESCENCE (PXRF) CHEMICAL DATA}

\section{Portable X-Ray Fluorescence (pXRF) Sample Location Map}

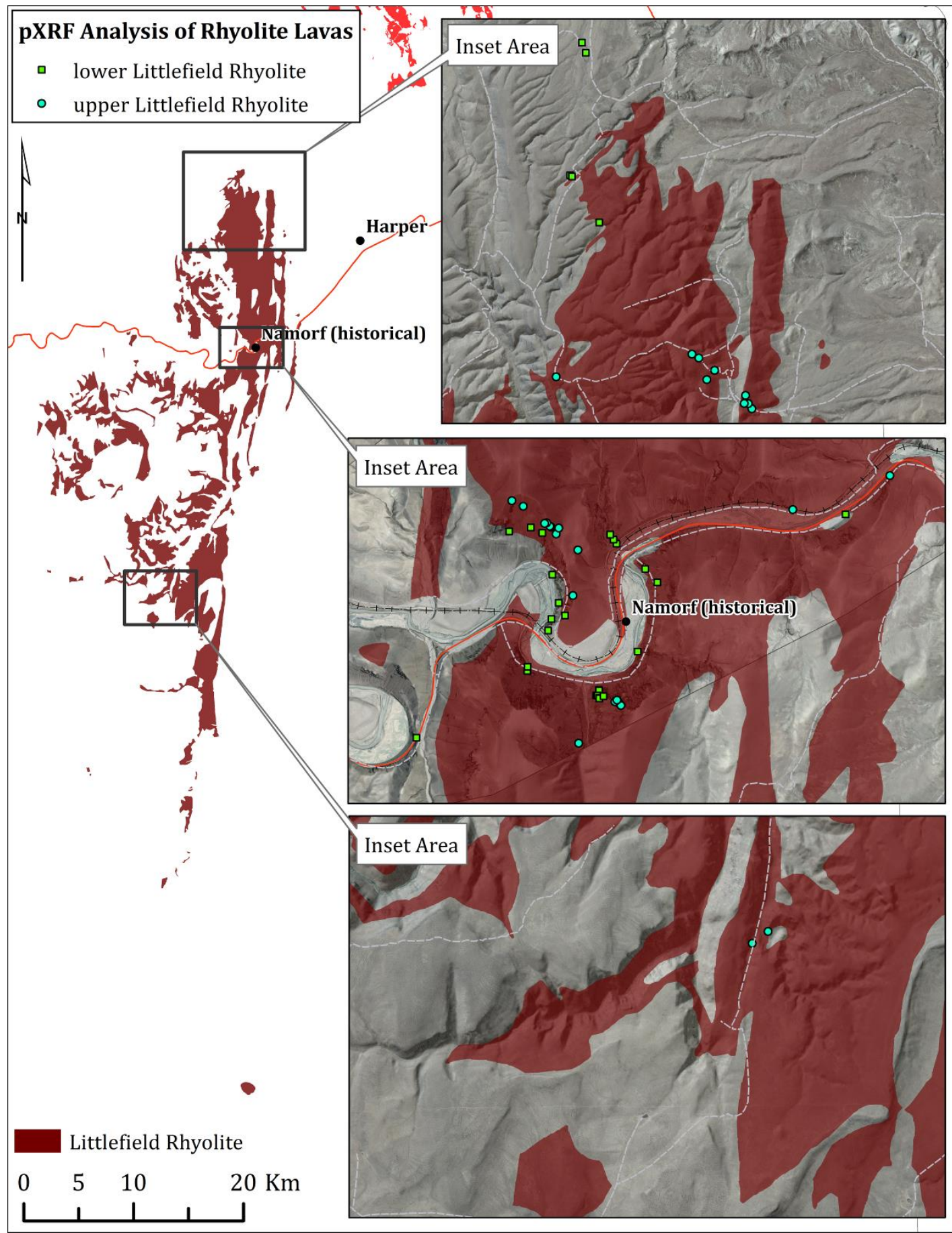

Figure 70: Map shows locations of Littlefield Rhyolite samples analyzed by pXRF. Samples were identified as being either upper or lower Littlefield Rhyolite based on distinct differences in $\mathrm{Zr}$ and $\mathrm{Nb}$ concentrations. 


\section{Portable X-Ray Fluorescence (pXRF) Data for Rhyolite Lava Samples}

Table 29: Portable X-Ray Fluorescence data for $\mathrm{Zr}$ and $\mathrm{Nb}$ concentrations of rhyolite lava samples. Sample locations are provided in NAD83 UTM 11N coordinates.

\begin{tabular}{|c|c|c|c|c|c|}
\hline Sample ID & $\begin{array}{c}\text { Easting, } \\
\text { meters }\end{array}$ & $\begin{array}{c}\begin{array}{c}\text { Northing, } \\
\text { meters }\end{array} \\
\end{array}$ & $\begin{array}{c}\begin{array}{c}\text { Elevation, } \\
\text { meters }\end{array} \\
\end{array}$ & $\begin{array}{c}\mathrm{Zr}, \\
\text { ppm }\end{array}$ & $\begin{array}{c}\text { Nb, } \\
\text { ppm }\end{array}$ \\
\hline "BW_13_01 & 441254 & 4848002 & 845 & 295 & 24 \\
\hline BW_13_02 & 441254 & 4848002 & 864 & 315 & 22 \\
\hline BW_13_03 & 441254 & 4848002 & 860 & 325 & 18 \\
\hline BW_13_03_r & 441254 & 4848002 & 860 & 305 & 22 \\
\hline BW_13_04 & 443097 & 4848422 & 799 & 302 & 18 \\
\hline BW_13_07_r1 & 440143 & 4847122 & 851 & 316 & 23 \\
\hline BW_13_07_r2 & 440143 & 4847122 & 851 & 304 & 20 \\
\hline BW_13_08 & 440148 & 4847159 & 822 & 324 & 23 \\
\hline BW_14_01 & 440787 & 4846920 & 834 & 309 & 20 \\
\hline BW_14_02 & 440787 & 4846915 & 860 & 288 & 11 \\
\hline BW_14_05 & 440772 & 4846870 & 877 & 315 & 18 \\
\hline BW_14_10 & 440786 & 4846843 & 893 & 311 & 20 \\
\hline BW_14_15 & 440974 & 4846783 & 1012 & 529 & 43 \\
\hline BW_14_16 & 440982 & 4846770 & 1018 & 528 & 44 \\
\hline BW_14_18 & 443517 & 4848758 & 817 & 545 & 30 \\
\hline BW_14_19 & 440827 & 4846862 & 917 & 283 & 17 \\
\hline BW_14_25 & 440347 & 4847480 & 820 & 307 & 19 \\
\hline BW_14_26 & 440383 & 4847584 & 818 & 278 & 17 \\
\hline BW_14_27 & 440408 & 4847987 & 821 & 315 & 18 \\
\hline BW_14_28 & 441153 & 4847255 & 810 & 519 & 44 \\
\hline BW_14_29a & 439108 & 4846556 & 844 & 306 & 23 \\
\hline BW_14_34 & 440361 & 4847676 & 915 & 532 & 39 \\
\hline BW_14_39a & 433135 & 4826068 & 1266 & 538 & 38 \\
\hline BW_14_39b & 433135 & 4826068 & 1266 & 578 & 40 \\
\hline BW_14_40 & 442439 & 4856631 & 1010 & 507 & 37 \\
\hline BW_14_41a & 441441 & 4857339 & 1147 & 531 & 40 \\
\hline BW_14_41b & 441441 & 4857339 & 1147 & 558 & 37 \\
\hline BW_14_42a & 442360 & 4856755 & 1045 & 531 & 40 \\
\hline BW_14_42a_r & 442360 & 4856755 & 1045 & 540 & 35 \\
\hline BW_14_44 & 442307 & 4856944 & 1105 & 509 & 35 \\
\hline BW_14_46a & 439006 & 4864889 & 1073 & 291 & 13 \\
\hline BW_14_48 & 438927 & 4865122 & 1065 & 455 & 36 \\
\hline BW_14_54 & 438528 & 4862120 & 1202 & 293 & 18 \\
\hline BW_14_55 & 438570 & 4862087 & 1193 & 317 & 23 \\
\hline BW_14_56 & 439144 & 4861016 & 1202 & 302 & 18 \\
\hline BW_14_57 & 438019 & 4857548 & 1393 & 522 & 40 \\
\hline BW_14_58a & 441127 & 4857932 & 1211 & 455 & 36 \\
\hline BW_14_58b & 441127 & 4857932 & 1211 & 510 & 35 \\
\hline BW_14_59 & 441283 & 4857837 & 1194 & 545 & 34 \\
\hline BW_14_60 & 441629 & 4857544 & 1133 & 526 & 36 \\
\hline BW_14_65 & 442169 & 4848566 & 805 & 518 & 43 \\
\hline BW_14_66 & 442620 & 4848485 & 799 & 540 & 40 \\
\hline BW_15_10 & 440416 & 4848420 & 1013 & 532 & 42 \\
\hline BW_15_11 & 440404 & 4848428 & 1019 & 424 & 32 \\
\hline BW_15_12 & 440378 & 4848460 & 1040 & 524 & 33 \\
\hline BW_15_13 & 440170 & 4848620 & 1119 & 544 & 38 \\
\hline BW_15_14 & 441003 & 4848244 & 806 & 261 & 16 \\
\hline BW_15_15 & 440979 & 4848283 & 828 & 298 & 18 \\
\hline BW_15_16 & 440950 & 4848330 & 852 & 288 & 18 \\
\hline BW_15_17 & 440070 & 4848676 & 1151 & 529 & 40 \\
\hline BW_15_23 & 440651 & 4848202 & 922 & 557 & 40 \\
\hline BW_15_25 & 440358 & 4848456 & 1042 & 553 & 41 \\
\hline BW_15_27 & 440332 & 4848370 & 1003 & 284 & 22 \\
\hline BW_15_28 & 440230 & 4848424 & 1005 & 274 & 21 \\
\hline BW_15_29 & 440033 & 4848397 & 978 & 302 & 13 \\
\hline BW_15_33 & 440486 & 4848409 & 935 & 538 & 37 \\
\hline BW_15_34 & 440583 & 4846443 & 893 & 543 & 37 \\
\hline
\end{tabular}

119 


\section{APPENDIX C: ELECTRON PROBE MICRO-ANALYZER (EPMA) DATA}

Electron microprobe analyses were performed on feldspar, pyroxene, and titanium-

magnetite phenocrysts of rhyolites using a Cameca, model SX 100, Electron Probe

Micro-Analyzer (EPMA).

\section{Upper Littlefield Rhyolite: Sample BW-14-67}

Table 30: Results of electron microprobe analyses of upper Littlefield Rhyolite pyroxene phenocrysts, followed by the average end-member composition.

\begin{tabular}{|c|c|c|c|c|c|c|c|c|c|c|}
\hline $\begin{array}{l}\text { BW-14-67 Pyroxene } \\
\text { EMP, normalized wt.\% }\end{array}$ & $\mathrm{SiO2}$ & TiO2 & Al203 & FeO & MnO & MgO & $\mathrm{CaO}$ & $\mathrm{Na} 20$ & Cr203 & ZnO \\
\hline BW-14-67-p1 & 47.88 & 0.52 & 0.54 & 30.69 & 1.05 & 0.43 & 18.51 & 0.28 & 0.00 & 0.09 \\
\hline BW-14-67-p1 & 48.06 & 0.54 & 0.84 & 29.02 & 0.91 & 1.40 & 18.89 & 0.27 & 0.01 & 0.06 \\
\hline BW-14-67-p1 & 47.93 & 0.56 & 0.80 & 29.40 & 0.98 & 1.46 & 18.47 & 0.31 & 0.00 & 0.09 \\
\hline BW-14-67-p2 & 48.46 & 0.52 & 0.83 & 28.82 & 0.99 & 1.72 & 18.26 & 0.29 & 0.00 & 0.11 \\
\hline BW-14-67-p2 & 48.29 & 0.49 & 0.81 & 29.07 & 1.02 & 1.68 & 18.24 & 0.30 & 0.01 & 0.10 \\
\hline BW-14-67-p2 & 48.00 & 0.53 & 0.79 & 29.60 & 0.91 & 1.40 & 18.35 & 0.31 & 0.00 & 0.08 \\
\hline BW-14-67-p3 & 48.37 & 0.52 & 0.91 & 28.20 & 1.01 & 2.33 & 18.34 & 0.27 & 0.00 & 0.05 \\
\hline BW-14-67-p3 & 48.06 & 0.52 & 0.84 & 29.16 & 0.99 & 1.81 & 18.19 & 0.32 & 0.00 & 0.10 \\
\hline BW-14-67-p3 & 48.25 & 0.50 & 0.80 & 29.02 & 1.06 & 1.50 & 18.52 & 0.34 & 0.00 & 0.02 \\
\hline BW-14-67-p4 & 48.19 & 0.46 & 0.82 & 29.13 & 1.02 & 1.78 & 18.27 & 0.31 & 0.00 & 0.03 \\
\hline BW-14-67-p4 & 47.74 & 0.48 & 0.83 & 29.58 & 1.04 & 1.64 & 18.36 & 0.32 & 0.00 & 0.03 \\
\hline BW-14-67-p4 & 47.47 & 0.48 & 0.82 & 29.15 & 0.95 & 1.51 & 18.40 & 1.10 & 0.01 & 0.10 \\
\hline BW-14-67-p5 & 47.97 & 0.59 & 0.70 & 30.01 & 0.93 & 0.71 & 18.72 & 0.28 & 0.00 & 0.09 \\
\hline BW-14-67-p5 & 48.16 & 0.51 & 0.71 & 29.60 & 0.94 & 1.16 & 18.49 & 0.35 & 0.03 & 0.05 \\
\hline BW-14-67-p5 & 48.41 & 0.50 & 0.76 & 29.32 & 0.99 & 1.33 & 18.37 & 0.28 & 0.00 & 0.05 \\
\hline BW-14-67-p6 & 48.18 & 0.57 & 0.84 & 29.35 & 1.07 & 1.37 & 18.24 & 0.33 & 0.02 & 0.03 \\
\hline BW-14-67-p6 & 47.85 & 0.57 & 0.84 & 29.51 & 0.98 & 1.41 & 18.52 & 0.27 & 0.02 & 0.03 \\
\hline BW-14-67-p6 & 48.21 & 0.58 & 0.83 & 29.17 & 0.94 & 1.45 & 18.41 & 0.32 & 0.00 & 0.09 \\
\hline BW-14-67-p7 & 48.07 & 0.49 & 0.86 & 29.06 & 1.03 & 1.70 & 18.36 & 0.32 & 0.05 & 0.05 \\
\hline BW-14-67-p7 & 48.42 & 0.48 & 0.85 & 28.78 & 0.97 & 1.64 & 18.49 & 0.30 & 0.02 & 0.05 \\
\hline BW-14-67-p7 & 48.28 & 0.52 & 0.80 & 29.10 & 0.97 & 1.45 & 18.48 & 0.31 & 0.01 & 0.07 \\
\hline BW-14-67-p8 & 47.98 & 0.59 & 0.90 & 29.20 & 1.04 & 1.59 & 18.32 & 0.30 & 0.00 & 0.08 \\
\hline BW-14-67-p8 & 48.00 & 0.61 & 0.92 & 29.07 & 1.05 & 1.59 & 18.33 & 0.35 & 0.00 & 0.09 \\
\hline BW-14-67-p8 & 48.22 & 0.45 & 0.82 & 29.03 & 1.00 & 1.78 & 18.29 & 0.33 & 0.00 & 0.07 \\
\hline BW-14-67-p9 & 48.53 & 0.43 & 0.84 & 28.39 & 1.01 & 2.09 & 18.29 & 0.28 & 0.03 & 0.11 \\
\hline BW-14-67-p9 & 48.81 & 0.41 & 0.87 & 27.82 & 1.02 & 2.62 & 18.09 & 0.34 & 0.00 & 0.01 \\
\hline BW-14-67-p9 & 48.27 & 0.49 & 0.81 & 29.40 & 0.98 & 1.51 & 18.22 & 0.28 & 0.00 & 0.04 \\
\hline BW-14-67-p10 & 48.12 & 0.44 & 0.76 & 29.30 & 1.06 & 1.75 & 18.24 & 0.26 & 0.00 & 0.06 \\
\hline BW-14-67-p10 & 48.14 & 0.49 & 0.81 & 29.12 & 1.00 & 1.67 & 18.43 & 0.28 & 0.00 & 0.05 \\
\hline BW-14-67-p10 & 48.35 & 0.51 & 0.81 & 28.99 & 1.00 & 1.48 & 18.51 & 0.27 & 0.03 & 0.04 \\
\hline BW-14-67-p11 & 47.88 & 0.51 & 0.81 & 29.28 & 1.00 & 1.64 & 18.61 & 0.27 & 0.00 & 0.00 \\
\hline BW-14-67-p11 & 47.91 & 0.50 & 0.82 & 29.37 & 1.04 & 1.55 & 18.48 & 0.27 & 0.01 & 0.05 \\
\hline BW-14-67-p11 & 48.02 & 0.55 & 0.75 & 29.57 & 1.03 & 1.29 & 18.53 & 0.25 & 0.00 & 0.02 \\
\hline Average pyroxene & 48.14 & 0.51 & 0.81 & 29.19 & 1.00 & 1.56 & 18.40 & 0.32 & 0.01 & 0.06 \\
\hline \multirow[t]{2}{*}{$1 \sigma$} & 0.26 & 0.05 & 0.07 & 0.49 & 0.04 & 0.38 & 0.16 & 0.14 & 0.01 & 0.03 \\
\hline & $\begin{array}{c}\text { \%En } \\
\% \mathrm{Fs} \\
\% \mathrm{Wo}\end{array}$ & $\begin{array}{c}5.00 \\
52.55 \\
42.44 \\
\end{array}$ & & & & & & & & \\
\hline
\end{tabular}


Table 31: Results of electron microprobe analyses of upper Littlefield Rhyolite titanomagnetite phenocrysts.

\begin{tabular}{ccccccccccc}
\hline \hline $\begin{array}{c}\text { BW-14-67 TiFe } \\
\text { EMP, normalized wt.\% }\end{array}$ & Si02 & TiO2 & Al203 & Fe0 & MnO & Mg0 & Ca0 & Na20 & Cr203 & Zn0 \\
\hline BW-14-67-p1 & 5.41 & 27.29 & 1.43 & 64.01 & 0.92 & 0.17 & 0.18 & 0.04 & 0.00 & 0.54 \\
BW-14-67-p1 & 5.48 & 27.34 & 1.37 & 64.22 & 0.80 & 0.13 & 0.16 & 0.05 & 0.02 & 0.44 \\
BW-14-67-p3 & 8.48 & 32.49 & 1.67 & 55.50 & 0.64 & 0.17 & 0.17 & 0.13 & 0.00 & 0.75 \\
BW-14-67-p3 & 6.73 & 30.80 & 1.52 & 59.25 & 0.72 & 0.17 & 0.12 & 0.15 & 0.00 & 0.55 \\
BW-14-67-p4 & 8.72 & 31.86 & 1.57 & 56.14 & 0.74 & 0.18 & 0.24 & 0.07 & 0.00 & 0.48 \\
BW-14-67-p4 & 0.16 & 22.74 & 1.08 & 74.67 & 0.96 & 0.08 & 0.07 & 0.01 & 0.02 & 0.19 \\
BW-14-67-p6 & 6.06 & 30.32 & 1.59 & 60.41 & 0.79 & 0.20 & 0.19 & 0.06 & 0.00 & 0.38 \\
BW-14-67-p6 & 10.86 & 34.87 & 2.00 & 50.42 & 0.65 & 0.25 & 0.35 & 0.12 & 0.00 & 0.48 \\
BW-14-67-p8 & 0.23 & 23.28 & 1.02 & 74.11 & 0.89 & 0.13 & 0.02 & 0.03 & 0.00 & 0.28 \\
BW-14-67-p8 & 0.90 & 24.54 & 1.08 & 72.12 & 0.86 & 0.12 & 0.02 & 0.03 & 0.00 & 0.34 \\
BW-14-67-p10 & 0.30 & 22.88 & 1.05 & 74.39 & 0.95 & 0.11 & 0.06 & 0.01 & 0.00 & 0.25 \\
BW-14-67-p10 & 0.16 & 22.55 & 1.03 & 74.86 & 0.94 & 0.09 & 0.08 & 0.03 & 0.02 & 0.24 \\
BW-14-67-p11 & 0.23 & 21.99 & 1.08 & 75.38 & 0.90 & 0.09 & 0.02 & 0.00 & 0.00 & 0.31 \\
BW-14-67-p11 & 0.18 & 22.11 & 1.03 & 75.36 & 0.93 & 0.07 & 0.02 & 0.00 & 0.00 & 0.29 \\
\hline Average TiFe & 3.85 & 26.79 & 1.32 & 66.49 & 0.84 & 0.14 & 0.12 & 0.05 & 0.00 & 0.39 \\
16 & 3.93 & 4.51 & 0.31 & 8.92 & 0.11 & 0.05 & 0.10 & 0.05 & 0.01 & 0.15 \\
\hline
\end{tabular}


Table 32: Results of electron microprobe analyses of upper Littlefield Rhyolite feldspar phenocrysts, followed by the average end-member composition.

\begin{tabular}{|c|c|c|c|c|c|c|c|c|}
\hline $\begin{array}{l}\text { BW-14-67 Feldspar } \\
\text { EMP, normalized wt.\% }\end{array}$ & Si02 & Al203 & FeO & MgO & CaO & Na2O & K20 & Ba0 \\
\hline BW-14-67_F1 & 61.997 & 23.726 & 0.396 & 0.000 & 5.405 & 7.348 & 1.048 & 0.080 \\
\hline BW-14-67_F1 & 62.717 & 23.399 & 0.430 & 0.008 & 4.965 & 7.280 & 1.146 & 0.055 \\
\hline BW-14-67_F1 & 62.567 & 23.035 & 0.519 & 0.000 & 4.977 & 7.630 & 1.207 & 0.065 \\
\hline BW-14-67_F2 & 62.483 & 23.604 & 0.444 & 0.000 & 4.898 & 7.441 & 1.089 & 0.040 \\
\hline BW-14-67_F2 & 62.928 & 23.049 & 0.429 & 0.000 & 4.879 & 7.501 & 1.175 & 0.038 \\
\hline BW-14-67_F2 & 62.814 & 23.223 & 0.433 & 0.000 & 4.726 & 7.596 & 1.171 & 0.037 \\
\hline BW-14-67_F3 & 61.589 & 24.054 & 0.509 & 0.000 & 5.647 & 7.192 & 0.966 & 0.042 \\
\hline BW-14-67_F3 & 62.699 & 23.432 & 0.517 & 0.000 & 4.873 & 7.276 & 1.152 & 0.050 \\
\hline BW-14-67_F4 & 64.176 & 22.197 & 0.456 & 0.005 & 3.822 & 7.667 & 1.620 & 0.057 \\
\hline BW-14-67_F4 & 62.625 & 23.195 & 0.515 & 0.005 & 4.939 & 7.536 & 1.186 & 0.000 \\
\hline BW-14-67_F5 & 63.591 & 22.524 & 0.332 & 0.000 & 3.252 & 7.890 & 2.363 & 0.049 \\
\hline BW-14-67_F5 & 64.129 & 22.053 & 0.334 & 0.003 & 3.012 & 7.895 & 2.536 & 0.038 \\
\hline BW-14-67_F5 & 65.549 & 21.084 & 0.324 & 0.000 & 1.957 & 7.447 & 3.577 & 0.064 \\
\hline BW-14-67_F6 & 62.963 & 22.950 & 0.501 & 0.000 & 4.552 & 7.660 & 1.335 & 0.039 \\
\hline BW-14-67_F6 & 63.087 & 22.825 & 0.430 & 0.000 & 4.743 & 7.549 & 1.304 & 0.063 \\
\hline BW-14-67_F7 & 62.501 & 23.390 & 0.485 & 0.000 & 5.032 & 7.377 & 1.151 & 0.062 \\
\hline BW-14-67_F7 & 62.458 & 23.534 & 0.501 & 0.000 & 5.070 & 7.255 & 1.129 & 0.054 \\
\hline BW-14-67_F8 & 62.429 & 23.234 & 0.522 & 0.036 & 4.995 & 7.559 & 1.165 & 0.061 \\
\hline BW-14-67_F8 & 62.998 & 22.936 & 0.493 & 0.010 & 4.823 & 7.434 & 1.249 & 0.057 \\
\hline BW-14-67_F8 & 61.823 & 23.864 & 0.537 & 0.007 & 5.510 & 7.196 & 1.005 & 0.059 \\
\hline Average feldspar & 62.906 & 23.065 & 0.455 & 0.004 & 4.604 & 7.486 & 1.429 & 0.050 \\
\hline \multirow[t]{4}{*}{$1 \sigma$} & 0.900 & 0.691 & 0.067 & 0.008 & 0.912 & 0.203 & 0.653 & 0.016 \\
\hline & $\% \mathrm{Or}$ & 8.57 & & & & & & \\
\hline & $\% A b$ & 68.24 & & & & & & \\
\hline & $\% \mathrm{An}$ & 23.19 & & & & & & \\
\hline
\end{tabular}




\section{Lower Littlefield Rhyolite: Sample BW-14-19}

Table 33: Results of electron microprobe analyses of lower Littlefield Rhyolite pyroxene phenocrysts, followed by the average end-member composition.

\begin{tabular}{|c|c|c|c|c|c|c|c|c|c|c|}
\hline $\begin{array}{l}\text { BW-14-19 Pyroxene } \\
\text { EMP, normalized wt.\% }\end{array}$ & $\mathrm{SiO2}$ & TiO2 & Al203 & FeO & Mno & Mg0 & $\mathrm{CaO}$ & Na20 & Cr203 & $\mathrm{ZnO}$ \\
\hline BW-14-19-p1_ctr-rim & 50.41 & 0.32 & 0.49 & 29.96 & 1.22 & 12.82 & 4.65 & 0.06 & 0.01 & 0.06 \\
\hline BW-14-19-p1_ctr-rim & 50.31 & 0.29 & 0.51 & 30.00 & 1.24 & 12.81 & 4.72 & 0.06 & 0.01 & 0.04 \\
\hline BW-14-19-p1_ctr-rim & 50.31 & 0.33 & 0.50 & 29.95 & 1.25 & 12.66 & 4.79 & 0.11 & 0.00 & 0.11 \\
\hline BW-14-19-p2_ctr-rim & 50.50 & 0.31 & 0.50 & 29.71 & 1.32 & 12.97 & 4.52 & 0.05 & 0.00 & 0.12 \\
\hline BW-14-19-p2_ctr-rim & 50.60 & 0.30 & 0.50 & 29.97 & 1.18 & 12.86 & 4.43 & 0.04 & 0.01 & 0.10 \\
\hline BW-14-19-p2_ctr-rim & 50.10 & 0.32 & 0.51 & 30.14 & 1.25 & 13.14 & 4.38 & 0.06 & 0.00 & 0.09 \\
\hline BW-14-19-p3_ctr-rim & 49.97 & 0.31 & 0.47 & 31.08 & 1.34 & 11.82 & 4.85 & 0.06 & 0.00 & 0.09 \\
\hline BW-14-19-p3_ctr-rim & 50.23 & 0.30 & 0.46 & 31.09 & 1.30 & 11.69 & 4.84 & 0.04 & 0.00 & 0.04 \\
\hline BW-14-19-p3_ctr-rim & 49.96 & 0.29 & 0.45 & 31.35 & 1.26 & 11.67 & 4.84 & 0.07 & 0.01 & 0.09 \\
\hline BW-14-19-p4_ctr-rim & 50.35 & 0.30 & 0.51 & 29.95 & 1.20 & 13.16 & 4.33 & 0.05 & 0.00 & 0.14 \\
\hline BW-14-19-p4_ctr-rim & 50.39 & 0.33 & 0.50 & 30.15 & 1.18 & 12.95 & 4.30 & 0.11 & 0.02 & 0.08 \\
\hline BW-14-19-p4_ctr-rim & 50.54 & 0.31 & 0.50 & 29.91 & 1.25 & 12.90 & 4.43 & 0.06 & 0.00 & 0.08 \\
\hline BW-14-19-p5_ctr-rim & 50.30 & 0.33 & 0.50 & 30.51 & 1.22 & 13.23 & 3.82 & 0.04 & 0.00 & 0.04 \\
\hline BW-14-19-p5_ctr-rim & 50.16 & 0.34 & 0.51 & 30.66 & 1.17 & 13.04 & 3.99 & 0.05 & 0.02 & 0.07 \\
\hline BW-14-19-p5_ctr-rim & 50.16 & 0.31 & 0.50 & 30.41 & 1.16 & 13.12 & 4.23 & 0.07 & 0.00 & 0.04 \\
\hline BW-14-19-p6_ctr-rim & 50.08 & 0.30 & 0.54 & 30.20 & 1.22 & 13.07 & 4.48 & 0.08 & 0.00 & 0.02 \\
\hline BW-14-19-p6_ctr-rim & 50.22 & 0.31 & 0.52 & 30.23 & 1.25 & 12.87 & 4.52 & 0.06 & 0.00 & 0.03 \\
\hline BW-14-19-p6_ctr-rim & 50.46 & 0.27 & 0.50 & 30.08 & 1.19 & 12.97 & 4.39 & 0.04 & 0.01 & 0.10 \\
\hline BW-14-19-p7_ctr-rim & 50.17 & 0.30 & 0.52 & 30.19 & 1.10 & 13.13 & 4.41 & 0.10 & 0.01 & 0.07 \\
\hline BW-14-19-p7_ctr-rim & 50.41 & 0.29 & 0.52 & 30.12 & 1.18 & 13.00 & 4.37 & 0.07 & 0.00 & 0.05 \\
\hline BW-14-19-p7_ctr-rim & 50.51 & 0.32 & 0.51 & 29.88 & 1.16 & 12.88 & 4.57 & 0.11 & 0.00 & 0.07 \\
\hline BW-14-19-p8_ctr-rim & 50.04 & 0.29 & 0.51 & 30.28 & 1.18 & 13.41 & 4.16 & 0.07 & 0.00 & 0.06 \\
\hline BW-14-19-p8_ctr-rim & 49.96 & 0.31 & 0.50 & 30.32 & 1.23 & 13.35 & 4.22 & 0.06 & 0.01 & 0.05 \\
\hline BW-14-19-p8_ctr-rim & 50.03 & 0.29 & 0.52 & 30.13 & 1.23 & 13.31 & 4.41 & 0.04 & 0.00 & 0.03 \\
\hline BW-14-19-p9_ctr-rim & 50.14 & 0.29 & 0.54 & 29.86 & 1.19 & 12.90 & 4.90 & 0.09 & 0.00 & 0.09 \\
\hline BW-14-19-p9_ctr-rim & 50.09 & 0.29 & 0.51 & 30.19 & 1.18 & 12.96 & 4.64 & 0.04 & 0.00 & 0.09 \\
\hline BW-14-19-p9_ctr-rim & 50.26 & 0.32 & 0.52 & 30.09 & 1.26 & 12.84 & 4.58 & 0.07 & 0.00 & 0.07 \\
\hline BW-14-19-p10_ctr-rim & 50.03 & 0.30 & 0.53 & 30.31 & 1.19 & 13.10 & 4.41 & 0.08 & 0.02 & 0.04 \\
\hline BW-14-19-p10_ctr-rim & 49.92 & 0.27 & 0.52 & 30.33 & 1.24 & 13.18 & 4.30 & 0.11 & 0.01 & 0.12 \\
\hline BW-14-19-p10_ctr-rim & 49.89 & 0.33 & 0.53 & 30.27 & 1.18 & 12.96 & 4.61 & 0.08 & 0.01 & 0.15 \\
\hline Average pyroxene & 50.22 & 0.31 & 0.51 & 30.24 & 1.22 & 12.89 & 4.47 & 0.07 & 0.01 & 0.07 \\
\hline $1 \sigma$ & 0.20 & 0.02 & 0.02 & 0.38 & 0.05 & 0.43 & 0.25 & 0.02 & 0.01 & 0.03 \\
\hline & $\begin{array}{c}\text { \%En } \\
\% \mathrm{Fs} \\
\% \mathrm{Wo}\end{array}$ & $\begin{array}{c}38.99 \\
51.30 \\
9.71\end{array}$ & & & & & & & & \\
\hline
\end{tabular}


Table 34: Results of electron microprobe analyses of lower Littlefield Rhyolite titanomagnetite phenocrysts.

\begin{tabular}{|c|c|c|c|c|c|c|c|c|c|c|}
\hline $\begin{array}{c}\text { BW-14-19 TiFe } \\
\text { EMP, normalized wt.\% }\end{array}$ & SiO2 & TiO2 & Al203 & FeO & MnO & Mg0 & $\mathrm{CaO}$ & Na20 & Cr203 & ZnO \\
\hline BW-14-19-p1_ctr-rim & 4.84 & 27.63 & 2.05 & 62.64 & 0.74 & 0.73 & 1.03 & 0.03 & 0.05 & 0.26 \\
\hline BW-14-19-p1_ctr-rim & 0.86 & 23.32 & 1.82 & 71.74 & 0.83 & 1.02 & 0.11 & 0.01 & 0.05 & 0.23 \\
\hline BW-14-19-p2_ctr-rim & 3.60 & 26.41 & 2.19 & 63.60 & 3.02 & 0.49 & 0.31 & 0.08 & 0.04 & 0.26 \\
\hline BW-14-19-p2_ctr-rim & 4.91 & 27.03 & 2.07 & 63.08 & 1.03 & 0.95 & 0.76 & 0.02 & 0.02 & 0.13 \\
\hline BW-14-19-p5_ctr-rim & 0.14 & 22.40 & 1.62 & 72.39 & 0.75 & 1.04 & 1.46 & 0.04 & 0.00 & 0.16 \\
\hline BW-14-19-p5_ctr-rim & 0.08 & 22.55 & 1.65 & 73.72 & 0.78 & 1.05 & 0.03 & 0.00 & 0.01 & 0.14 \\
\hline BW-14-19-p6_ctr-rim & 2.11 & 25.21 & 1.90 & 67.51 & 1.73 & 0.89 & 0.32 & 0.03 & 0.02 & 0.28 \\
\hline BW-14-19-p6_ctr-rim & 0.97 & 24.30 & 1.79 & 70.57 & 1.05 & 0.97 & 0.16 & 0.02 & 0.00 & 0.17 \\
\hline BW-14-19-p6_ctr-rim & 1.17 & 24.03 & 1.84 & 70.50 & 1.00 & 1.06 & 0.16 & 0.05 & 0.01 & 0.18 \\
\hline BW-14-19-p6_ctr-rim & 2.40 & 25.51 & 1.85 & 67.46 & 1.10 & 0.91 & 0.46 & 0.02 & 0.00 & 0.29 \\
\hline BW-14-19-p8_ctr-rim & 1.00 & 24.10 & 1.86 & 70.41 & 1.17 & 1.11 & 0.07 & 0.02 & 0.02 & 0.24 \\
\hline BW-14-19-p8_ctr-rim & 3.16 & 26.25 & 2.01 & 65.62 & 1.31 & 0.94 & 0.51 & 0.04 & 0.00 & 0.15 \\
\hline BW-14-19-p10_ctr-rim & 3.50 & 26.75 & 2.00 & 64.63 & 1.49 & 0.84 & 0.57 & 0.00 & 0.00 & 0.22 \\
\hline BW-14-19-p10_ctr-rim & 2.23 & 25.37 & 1.83 & 67.67 & 1.27 & 0.98 & 0.42 & 0.00 & 0.00 & 0.22 \\
\hline BW-14-19-p10_ctr-rim & 0.92 & 23.87 & 1.80 & 70.36 & 1.98 & 0.85 & 0.08 & 0.00 & 0.00 & 0.14 \\
\hline BW-14-19-p10_ctr-rim & 3.04 & 24.58 & 2.12 & 66.67 & 2.09 & 0.91 & 0.34 & 0.00 & 0.04 & 0.22 \\
\hline Average TiFe & 2.18 & 24.96 & 1.90 & 68.03 & 1.33 & 0.92 & 0.42 & 0.02 & 0.02 & 0.21 \\
\hline $1 \sigma$ & 1.55 & 1.58 & 0.16 & 3.48 & 0.61 & 0.15 & 0.39 & 0.02 & 0.02 & 0.05 \\
\hline & $\begin{array}{c}\% \mathrm{Ti} \\
\% \mathrm{Fe} \\
\% \mathrm{Mg} \\
\% \mathrm{Mn} \\
\end{array}$ & $\begin{array}{c}24.01 \\
72.79 \\
1.76 \\
1.44 \\
\end{array}$ & & & & & & & & \\
\hline
\end{tabular}


Table 35: Results of electron microprobe analyses of lower Littlefield Rhyolite feldspar phenocrysts, followed by the average end-member composition.

\begin{tabular}{|c|c|c|c|c|c|c|c|c|}
\hline $\begin{array}{l}\text { BW-14-19 Feldspar } \\
\text { EMP, normalized wt.\% }\end{array}$ & SiO2 & Al203 & FeO & MgO & CaO & Na2O & K2O & BaO \\
\hline BW-14-19_F1 & 59.323 & 25.254 & 0.543 & 0.041 & 7.687 & 6.274 & 0.804 & 0.075 \\
\hline BW-14-19_F1 & 59.599 & 25.299 & 0.500 & 0.025 & 7.263 & 6.376 & 0.876 & 0.062 \\
\hline BW-14-19_F1 & 60.255 & 24.816 & 0.443 & 0.042 & 7.071 & 6.424 & 0.892 & 0.055 \\
\hline BW-14-19_F2 & 59.161 & 25.481 & 0.550 & 0.029 & 7.609 & 6.303 & 0.772 & 0.096 \\
\hline BW-14-19_F2 & 59.427 & 25.055 & 0.561 & 0.034 & 7.562 & 6.478 & 0.800 & 0.082 \\
\hline BW-14-19_F2 & 58.721 & 25.728 & 0.506 & 0.032 & 8.025 & 6.180 & 0.723 & 0.085 \\
\hline BW-14-19_F3 & 57.186 & 26.921 & 0.498 & 0.031 & 9.104 & 5.596 & 0.563 & 0.100 \\
\hline BW-14-19_F3 & 58.656 & 25.814 & 0.519 & 0.043 & 8.124 & 6.029 & 0.734 & 0.081 \\
\hline BW-14-19_F3 & 58.878 & 25.834 & 0.512 & 0.032 & 7.729 & 6.182 & 0.763 & 0.071 \\
\hline BW-14-19_F4 & 58.390 & 26.166 & 0.498 & 0.038 & 8.082 & 6.055 & 0.706 & 0.066 \\
\hline BW-14-19_F4 & 57.386 & 26.783 & 0.516 & 0.038 & 8.764 & 5.801 & 0.609 & 0.105 \\
\hline BW-14-19_F5 & 57.309 & 26.847 & 0.479 & 0.029 & 8.578 & 6.025 & 0.630 & 0.102 \\
\hline BW-14-19_F5 & 58.926 & 25.538 & 0.485 & 0.027 & 7.856 & 6.309 & 0.791 & 0.068 \\
\hline BW-14-19_F6 & 57.534 & 26.392 & 0.466 & 0.036 & 8.815 & 5.997 & 0.640 & 0.120 \\
\hline BW-14-19_F6 & 59.499 & 25.175 & 0.552 & 0.029 & 7.521 & 6.313 & 0.830 & 0.083 \\
\hline BW-14-19_F7 & 59.398 & 25.343 & 0.465 & 0.034 & 7.529 & 6.355 & 0.801 & 0.075 \\
\hline BW-14-19_F7 & 59.904 & 25.084 & 0.552 & 0.027 & 7.084 & 6.411 & 0.861 & 0.077 \\
\hline BW-14-19_F7 & 59.652 & 25.162 & 0.470 & 0.037 & 7.307 & 6.475 & 0.839 & 0.058 \\
\hline BW-14-19_F8 & 59.361 & 25.290 & 0.480 & 0.039 & 7.484 & 6.481 & 0.784 & 0.081 \\
\hline BW-14-19_F8 & 57.904 & 26.389 & 0.529 & 0.040 & 8.433 & 5.954 & 0.651 & 0.100 \\
\hline BW-14-19_F8 & 58.438 & 25.889 & 0.509 & 0.036 & 8.328 & 6.049 & 0.661 & 0.092 \\
\hline Average feldspar & 58.805 & 25.727 & 0.506 & 0.034 & 7.902 & 6.194 & 0.749 & 0.083 \\
\hline $1 \sigma$ & 0.901 & 0.635 & 0.033 & 0.005 & 0.587 & 0.240 & 0.094 & 0.017 \\
\hline & $\% \mathrm{Or}$ & 4.46 & & & & & & \\
\hline & $\% \mathrm{Ab}$ & 56.03 & & & & & & \\
\hline & $\% A n$ & 39.51 & & & & & & \\
\hline
\end{tabular}




\section{Dinner Creek Tuff: Sample BW-14-45}

Table 36: Results of electron microprobe analyses of Dinner Creek Tuff, sample BW-14-45 pyroxene phenocrysts, followed by the average end-member composition. Note that sample BW-14-45 is geochemically equivalent to Dinner Creek Tuff unit 1 of Streck et al. (2015), but it is not stratigraphically equivalent to Dinner Creek Tuff unit 1 that is commonly observed throughout the Malheur River Gorge. Stratigraphic position and overall distribution of the source of sample BW-14-45 is currently unknown, other than that the unit is younger than the lower Littlefield Rhyolite.

\begin{tabular}{|c|c|c|c|c|c|c|c|c|c|c|}
\hline $\begin{array}{l}\text { BW-14-45 Pyroxene } \\
\text { EMP, normalized wt.\% }\end{array}$ & SiO2 & TiO2 & Al203 & $\mathrm{FeO}$ & MnO & Mg0 & $\mathrm{CaO}$ & Na20 & Cr203 & Zno \\
\hline BW-14-45_pyx_ctr-rim(2) & 48.40 & 0.28 & 0.46 & 28.09 & 1.43 & 2.39 & 18.40 & 0.41 & 0.02 & 0.13 \\
\hline BW-14-45_pyx_ctr-rim(2) & 49.45 & 0.27 & 0.44 & 26.53 & 1.44 & 2.85 & 18.46 & 0.43 & 0.01 & 0.12 \\
\hline BW-14-45_pyx_ctr-rim(2) & 49.85 & 0.18 & 0.58 & 23.56 & 1.34 & 5.59 & 18.39 & 0.40 & 0.00 & 0.09 \\
\hline BW-14-45_pyx_ctr-rim(2) & 49.03 & 0.23 & 0.43 & 26.97 & 1.41 & 3.17 & 18.21 & 0.42 & 0.02 & 0.10 \\
\hline BW-14-45_pyx_ctr-rim(2) & 48.80 & 0.23 & 0.40 & 27.55 & 1.31 & 2.64 & 18.58 & 0.39 & 0.01 & 0.10 \\
\hline BW-14-45_pyx_ctr-rim(2) & 49.05 & 0.24 & 0.41 & 27.17 & 1.38 & 2.74 & 18.43 & 0.44 & 0.00 & 0.15 \\
\hline BW-14-45_pyx_ctr-rim(2) & 48.89 & 0.27 & 0.40 & 27.62 & 1.44 & 2.47 & 18.43 & 0.38 & 0.00 & 0.10 \\
\hline BW-14-45_pyx_ctr-rim(2) & 48.99 & 0.26 & 0.47 & 26.70 & 1.40 & 3.05 & 18.64 & 0.38 & 0.00 & 0.10 \\
\hline BW-14-45_pyx_ctr-rim(2) & 49.10 & 0.24 & 0.51 & 25.38 & 1.37 & 4.29 & 18.62 & 0.37 & 0.02 & 0.10 \\
\hline BW-14-45_pyx_ctr-rim(2) & 49.25 & 0.23 & 0.51 & 25.65 & 1.43 & 4.31 & 18.13 & 0.40 & 0.00 & 0.07 \\
\hline BW-14-45_pyx_ctr-rim(2) & 49.14 & 0.25 & 0.48 & 26.11 & 1.30 & 3.51 & 18.70 & 0.35 & 0.00 & 0.16 \\
\hline BW-14-45_pyx_ctr-rim(2) & 49.35 & 0.25 & 0.47 & 26.41 & 1.34 & 3.20 & 18.54 & 0.37 & 0.00 & 0.07 \\
\hline BW-14-45_pyx_ctr-rim(2) & 49.71 & 0.22 & 0.56 & 25.40 & 1.43 & 4.43 & 17.79 & 0.38 & 0.00 & 0.08 \\
\hline BW-14-45_pyx_ctr-rim(2) & 48.92 & 0.21 & 0.54 & 26.20 & 1.38 & 4.06 & 18.28 & 0.35 & 0.00 & 0.07 \\
\hline BW-14-45_pyx_ctr-rim(2) & 49.00 & 0.30 & 0.44 & 27.95 & 1.39 & 2.45 & 17.97 & 0.40 & 0.00 & 0.09 \\
\hline BW-14-45_pyx_ctr-rim(2) & 49.06 & 0.23 & 0.47 & 26.55 & 1.40 & 3.33 & 18.43 & 0.39 & 0.01 & 0.14 \\
\hline BW-14-45_pyx_ctr-rim(2) & 49.21 & 0.22 & 0.55 & 25.45 & 1.51 & 4.40 & 18.09 & 0.41 & 0.00 & 0.15 \\
\hline BW-14-45_pyx_ctr-rim(2) & 48.64 & 0.22 & 0.42 & 27.06 & 1.45 & 3.01 & 18.75 & 0.31 & 0.00 & 0.13 \\
\hline BW-14-45_pyx_ctr-rim(2) & 48.39 & 0.32 & 0.57 & 29.03 & 1.44 & 2.15 & 17.58 & 0.41 & 0.00 & 0.11 \\
\hline BW-14-45_pyx_ctr-rim(2) & 48.64 & 0.25 & 0.46 & 26.90 & 1.36 & 3.07 & 18.82 & 0.35 & 0.00 & 0.14 \\
\hline Average pyroxene & 49.04 & 0.25 & 0.48 & 26.61 & 1.40 & 3.36 & 18.36 & 0.39 & 0.00 & 0.11 \\
\hline $1 \sigma$ & 0.38 & 0.03 & 0.06 & 1.20 & 0.05 & 0.89 & 0.32 & 0.03 & 0.01 & 0.03 \\
\hline & $\begin{array}{c}\text { En } \\
\% \mathrm{Fs} \\
\% \mathrm{Wo}\end{array}$ & $\begin{array}{l}10.66 \\
47.42 \\
41.92\end{array}$ & & & & & & & & \\
\hline
\end{tabular}


Table 37: Results of electron microprobe analyses of Dinner Creek Tuff, sample BW-14-45 feldspar phenocrysts, followed by the average end-member composition. Note that sample BW-14-45 is geochemically equivalent to Dinner Creek Tuff unit 1 of Streck et al. (2015), but it is not stratigraphically equivalent to Dinner Creek Tuff unit 1 that is commonly observed throughout the Malheur River Gorge. Stratigraphic position and overall distribution of the source of sample BW-14-45 is currently unknown, other than that the unit is younger than the lower Littlefield Rhyolite.

\begin{tabular}{ccccccccc}
\hline \hline BW-14-45 Feldspar & SiO2 & Al203 & FeO & Mg0 & CaO & Na20 & K20 & BaO \\
EMP, normalized wt.\% & & & & & & & & 0.033 \\
\hline BW-14-45_F1_ct-rim & 65.907 & 21.308 & 0.201 & 0.000 & 2.208 & 9.005 & 1.338 & 0.034 \\
BW-14-45_F1_ct-rim & 65.944 & 20.865 & 0.255 & 0.000 & 2.197 & 9.277 & 1.428 & 0.021 \\
BW-14-45_F1_ct-rim & 66.124 & 21.277 & 0.206 & 0.008 & 2.285 & 8.741 & 1.339 & 0.021 .037 \\
BW-14-45_F2_ct-rim & 65.718 & 21.305 & 0.279 & 0.002 & 2.139 & 9.057 & 1.467 & 0.032 \\
BW-14-45_F2_ct-rim & 65.472 & 21.539 & 0.211 & 0.001 & 2.118 & 9.167 & 1.447 & 0.044 \\
BW-14-45_F2_ct-rim & 65.558 & 21.314 & 0.329 & 0.000 & 2.223 & 9.079 & 1.488 & 0.009 \\
BW-14-45_F3_ct-rim & 66.500 & 21.093 & 0.190 & 0.000 & 1.616 & 8.611 & 1.979 & 0.011 \\
BW-14-45_F3_ct-rim & 65.637 & 21.186 & 0.211 & 0.004 & 2.392 & 9.246 & 1.304 & 0.020 \\
BW-14-45_F4_ct-rim & 65.882 & 21.375 & 0.267 & 0.009 & 2.062 & 8.933 & 1.439 & 0.032 \\
BW-14-45_F4_ct-rim & 66.059 & 21.237 & 0.191 & 0.003 & 2.079 & 8.978 & 1.425 & 0.027 \\
BW-14-45_F4_ct-rim & 65.741 & 21.392 & 0.257 & 0.000 & 2.208 & 8.980 & 1.372 & 0.050 \\
BW-14-45_F1_ct-rim & 65.772 & 21.096 & 0.300 & 0.000 & 2.218 & 9.261 & 1.302 & 0.051 \\
BW-14-45_F2_ct-rim & 65.881 & 21.383 & 0.197 & 0.007 & 2.085 & 9.012 & 1.436 & 0.000 \\
BW-14-45_F3_ct-rim & 66.899 & 20.717 & 0.213 & 0.002 & 1.588 & 8.585 & 1.978 & 0.017 \\
BW-14-45_F4_ct-rim & 66.431 & 21.836 & 0.236 & 0.000 & 2.208 & 7.754 & 1.492 & 0.042 \\
\hline Average feldspar & 65.968 & 21.262 & 0.236 & 0.002 & 2.109 & 8.913 & 1.482 & 0.028 \\
16 & 0.387 & 0.264 & 0.043 & 0.003 & 0.222 & 0.385 & 0.211 & 0.015 \\
\hline
\end{tabular}

\section{Epiclastic Tuff: Sample BW-14-12}

Table 38: Results of electron microprobe analyses of the epiclastic tuff feldspar phenocrysts, followed by the average end-member composition.

\begin{tabular}{|c|c|c|c|c|c|c|c|c|}
\hline $\begin{array}{l}\text { BW-14-12 Feldspar } \\
\text { EMP, normalized wt.\% }\end{array}$ & $\begin{array}{l}\text { SiO2 } \\
\end{array}$ & Al203 & FeO & Mg0 & CaO & Na20 & K20 & BaO \\
\hline BW-14-12-p1 & 80.667 & 12.453 & 1.136 & 0.007 & 0.242 & 1.137 & 4.252 & 0.104 \\
\hline BW-14-12-p2 & 78.271 & 11.780 & 1.103 & 0.000 & 0.233 & 3.079 & 5.435 & 0.099 \\
\hline BW-14-12-p3 & 66.885 & 19.137 & 0.180 & 0.000 & 0.235 & 5.440 & 8.121 & 0.004 \\
\hline BW-14-12-p4 & 66.681 & 18.989 & 0.196 & 0.001 & 0.216 & 5.808 & 8.098 & 0.012 \\
\hline BW-14-12-p5 & 79.533 & 13.024 & 1.258 & 0.000 & 0.251 & 1.276 & 4.543 & 0.114 \\
\hline BW-14-12-p6 & 78.080 & 11.990 & 1.219 & 0.000 & 0.244 & 3.346 & 4.998 & 0.124 \\
\hline Average feldspar & 75.020 & 14.562 & 0.849 & 0.001 & 0.237 & 3.348 & 5.908 & 0.076 \\
\hline $1 \sigma$ & 6.449 & 3.513 & 0.515 & 0.003 & 0.012 & 1.984 & 1.752 & 0.054 \\
\hline & $\begin{array}{l}\% \mathrm{Or} \\
\% \mathrm{Ab} \\
\% \mathrm{An}\end{array}$ & $\begin{array}{c}48.15 \\
50.73 \\
1.12\end{array}$ & & & & & & \\
\hline
\end{tabular}




\section{APPENDIX D: SCANNING ELECTRON MICROSCOPE (SEM) CHEMICAL DATA}

Scanning Electron Microscope quantitative analysis was performed on feldspar, pyroxene, and titanium-magnetite phenocrysts, in addition to apatite microlites, for polished billets of two samples of lower Littlefield Rhyolite.

\section{Lower Littlefield Rhyolite: Sample BW-13-02}

Table 39: Results of scanning electron microscope quantitative analyses of lower Littlefield Rhyolite pyroxene phenocrysts, followed by the average end-member composition.

\begin{tabular}{|c|c|c|c|c|c|c|c|c|c|c|c|}
\hline $\begin{array}{l}\text { BW-13-02 pyroxene } \\
\text { SEM, normalized wt.\% }\end{array}$ & $\mathrm{SiO2}$ & TiO2 & Al203 & FeO & MnO & MgO & CaO & $\mathrm{Na2O}$ & K2O & P205 & BaO \\
\hline Spectrum 11 & 49.85 & 0.36 & 0.47 & 30.85 & 1.27 & 12.32 & 4.88 & 0.00 & 0.00 & 0.00 & 0.00 \\
\hline Spectrum 12 & 49.58 & 0.27 & 0.46 & 31.18 & 1.29 & 12.35 & 4.86 & 0.00 & 0.00 & 0.00 & 0.00 \\
\hline Spectrum 13 & 49.46 & 0.37 & 0.42 & 31.15 & 1.27 & 12.32 & 5.01 & 0.00 & 0.00 & 0.00 & 0.00 \\
\hline Spectrum 14 & 49.79 & 0.30 & 0.51 & 30.67 & 1.34 & 12.36 & 5.02 & 0.00 & 0.00 & 0.00 & 0.00 \\
\hline Spectrum 15 & 49.56 & 0.39 & 0.65 & 30.88 & 1.27 & 10.93 & 6.33 & 0.00 & 0.00 & 0.00 & 0.00 \\
\hline Spectrum 16 & 49.80 & 0.34 & 0.46 & 30.83 & 1.32 & 12.34 & 4.92 & 0.00 & 0.00 & 0.00 & 0.00 \\
\hline Spectrum 17 & 49.66 & 0.30 & 0.49 & 31.19 & 1.27 & 12.24 & 4.85 & 0.00 & 0.00 & 0.00 & 0.00 \\
\hline Spectrum 34 & 49.77 & 0.30 & 0.53 & 31.24 & 1.29 & 12.33 & 4.55 & 0.00 & 0.00 & 0.00 & 0.00 \\
\hline Spectrum 44 & 49.58 & 0.43 & 0.50 & 31.37 & 1.27 & 12.04 & 4.80 & 0.00 & 0.00 & 0.00 & 0.00 \\
\hline Spectrum 45 & 49.61 & 0.30 & 0.53 & 31.50 & 1.31 & 12.28 & 4.45 & 0.00 & 0.00 & 0.00 & 0.00 \\
\hline Spectrum 46 & 49.78 & 0.30 & 0.48 & 31.96 & 1.32 & 12.67 & 3.49 & 0.00 & 0.00 & 0.00 & 0.00 \\
\hline Spectrum 47 & 50.04 & 0.34 & 0.40 & 31.68 & 1.35 & 12.77 & 3.41 & 0.00 & 0.00 & 0.00 & 0.00 \\
\hline Spectrum 48 & 49.81 & 0.35 & 0.44 & 31.69 & 1.31 & 12.75 & 3.64 & 0.00 & 0.00 & 0.00 & 0.00 \\
\hline Spectrum 49 & 49.86 & 0.37 & 0.45 & 31.13 & 1.38 & 12.45 & 4.36 & 0.00 & 0.00 & 0.00 & 0.00 \\
\hline Spectrum 50 & 49.60 & 0.33 & 0.44 & 31.39 & 1.32 & 12.24 & 4.69 & 0.00 & 0.00 & 0.00 & 0.00 \\
\hline Spectrum 51 & 49.61 & 0.37 & 0.48 & 31.37 & 1.31 & 12.20 & 4.65 & 0.00 & 0.00 & 0.00 & 0.00 \\
\hline Spectrum 52 & 49.63 & 0.32 & 0.48 & 31.36 & 1.29 & 12.28 & 4.66 & 0.00 & 0.00 & 0.00 & 0.00 \\
\hline Spectrum 53 & 49.66 & 0.33 & 0.47 & 31.47 & 1.29 & 12.31 & 4.47 & 0.00 & 0.00 & 0.00 & 0.00 \\
\hline Average pyroxene & 49.70 & 0.34 & 0.48 & 31.27 & 1.30 & 12.29 & 4.61 & 0.00 & 0.00 & 0.00 & 0.00 \\
\hline$\sigma$ & 0.14 & 0.04 & 0.05 & 0.34 & 0.03 & 0.39 & 0.66 & 0.00 & 0.00 & 0.00 & 0.00 \\
\hline & \%En & 37.08 & & & & & & & & & \\
\hline & $\% \mathrm{Fs}$ & 52.92 & & & & & & & & & \\
\hline & $\%$ Wo & 10.00 & & & & & & & & & \\
\hline
\end{tabular}


Table 40: Results of scanning electron microscope quantitative analyses of lower Littlefield Rhyolite titanomagnetite phenocrysts.

\begin{tabular}{cccccccccccc}
\hline \hline BW-13-02 TiFe & Si02 & Ti02 & Al203 & Fe0 & MnO & Mg0 & Ca0 & Na20 & K20 & P205 & Ba0 \\
SEM, normalized wt.\% & & & & & & & & & & & \\
\hline Spectrum 6 & 1.45 & 23.31 & 2.09 & 73.13 & 0.00 & 0.00 & 0.00 & 0.00 & 0.00 & 0.00 & 0.00 \\
Spectrum 7 & 0.00 & 23.40 & 1.94 & 73.08 & 0.70 & 0.89 & 0.00 & 0.00 & 0.00 & 0.00 & 0.00 \\
Spectrum 8 & 4.32 & 25.51 & 2.43 & 66.27 & 0.91 & 0.00 & 0.56 & 0.00 & 0.00 & 0.00 & 0.00 \\
Spectrum 9 & 3.55 & 25.00 & 2.87 & 67.46 & 1.13 & 0.00 & 0.00 & 0.00 & 0.00 & 0.00 & 0.00 \\
Spectrum 10 & 1.06 & 23.20 & 1.46 & 73.36 & 0.00 & 0.91 & 0.00 & 0.00 & 0.00 & 0.00 & 0.00 \\
Spectrum 18 & 0.54 & 22.42 & 1.70 & 73.60 & 0.79 & 0.96 & 0.00 & 0.00 & 0.00 & 0.00 & 0.00 \\
Spectrum 19 & 0.38 & 22.38 & 1.71 & 73.77 & 0.77 & 0.98 & 0.00 & 0.00 & 0.00 & 0.00 & 0.00 \\
Spectrum 20 & 1.76 & 24.25 & 1.83 & 70.04 & 0.76 & 0.85 & 0.18 & 0.23 & 0.10 & 0.00 & 0.00 \\
Spectrum 21 & 1.03 & 23.16 & 1.88 & 72.17 & 0.76 & 0.87 & 0.15 & 0.00 & 0.00 & 0.00 & 0.00 \\
Spectrum 23 & 1.01 & 22.84 & 1.80 & 72.61 & 0.74 & 0.90 & 0.09 & 0.00 & 0.00 & 0.00 & 0.00 \\
Spectrum 24 & 1.43 & 22.88 & 2.03 & 71.64 & 0.80 & 1.04 & 0.16 & 0.00 & 0.00 & 0.00 & 0.00 \\
Spectrum 25 & 1.10 & 22.55 & 1.92 & 72.45 & 0.89 & 0.97 & 0.12 & 0.00 & 0.00 & 0.00 & 0.00 \\
Spectrum 26 & 2.57 & 23.51 & 1.58 & 70.62 & 0.82 & 0.61 & 0.30 & 0.00 & 0.00 & 0.00 & 0.00 \\
Spectrum 54 & 0.37 & 22.19 & 1.71 & 74.16 & 0.71 & 0.87 & 0.00 & 0.00 & 0.00 & 0.00 & 0.00 \\
Spectrum 74 & 3.42 & 25.20 & 2.06 & 67.31 & 0.74 & 0.79 & 0.36 & 0.00 & 0.13 & 0.00 & 0.00 \\
Spectrum 75 & 0.34 & 21.88 & 1.67 & 74.44 & 0.71 & 0.96 & 0.00 & 0.00 & 0.00 & 0.00 & 0.00 \\
Spectrum 76 & 4.69 & 25.66 & 1.78 & 65.84 & 0.76 & 0.61 & 0.53 & 0.00 & 0.13 & 0.00 & 0.00 \\
Spectrum 77 & 6.94 & 27.24 & 2.17 & 61.04 & 0.81 & 0.67 & 0.70 & 0.20 & 0.21 & 0.00 & 0.00 \\
Spectrum 78 & 4.81 & 24.69 & 2.83 & 65.00 & 0.79 & 1.17 & 0.34 & 0.24 & 0.13 & 0.00 & 0.00 \\
\hline Average TiFe & 2.15 & 23.75 & 1.97 & 70.42 & 0.71 & 0.74 & 0.18 & 0.04 & 0.04 & 0.00 & 0.00 \\
o & 1.94 & 1.44 & 0.38 & 3.82 & 0.27 & 0.36 & 0.22 & 0.08 & 0.07 & 0.00 & 0.00 \\
\hline
\end{tabular}


Table 41: Results of scanning electron microscope quantitative analyses of lower Littlefield Rhyolite feldspar phenocrysts, followed by the average end-member composition.

\begin{tabular}{|c|c|c|c|c|c|c|c|c|c|c|c|}
\hline $\begin{array}{l}\text { BW-13-02 Feldspar } \\
\text { SEM, normalized wt.\% }\end{array}$ & $\mathrm{SiO2}$ & TiO2 & Al203 & FeO & MnO & Mg0 & $\overline{\mathrm{CaO}}$ & Na20 & K20 & P205 & BaO \\
\hline Spectrum 1 & 59.38 & 0.00 & 26.23 & 0.00 & 0.00 & 0.00 & 7.84 & 5.82 & 0.73 & 0.00 & 0.00 \\
\hline Spectrum 2 & 59.59 & 0.00 & 25.50 & 0.00 & 0.00 & 0.00 & 7.80 & 6.31 & 0.80 & 0.00 & 0.00 \\
\hline Spectrum 3 & 60.10 & 0.00 & 25.28 & 0.00 & 0.00 & 0.00 & 8.05 & 5.83 & 0.74 & 0.00 & 0.00 \\
\hline Spectrum 4 & 60.15 & 0.00 & 24.85 & 0.00 & 0.00 & 0.00 & 8.04 & 6.10 & 0.87 & 0.00 & 0.00 \\
\hline Spectrum 5 & 60.25 & 0.00 & 24.61 & 0.99 & 0.00 & 0.00 & 7.17 & 6.25 & 0.74 & 0.00 & 0.00 \\
\hline Spectrum 28 & 59.92 & 0.00 & 24.84 & 0.61 & 0.00 & 0.00 & 7.37 & 6.35 & 0.91 & 0.00 & 0.00 \\
\hline Spectrum 29 & 60.00 & 0.00 & 24.73 & 0.57 & 0.00 & 0.00 & 7.36 & 6.40 & 0.95 & 0.00 & 0.00 \\
\hline Spectrum 30 & 60.06 & 0.00 & 24.73 & 0.54 & 0.00 & 0.00 & 7.37 & 6.37 & 0.92 & 0.00 & 0.00 \\
\hline Spectrum 31 & 60.55 & 0.00 & 24.49 & 0.60 & 0.00 & 0.00 & 6.97 & 6.46 & 0.93 & 0.00 & 0.00 \\
\hline Spectrum 32 & 60.32 & 0.00 & 24.64 & 0.60 & 0.00 & 0.00 & 7.17 & 6.33 & 0.95 & 0.00 & 0.00 \\
\hline Spectrum 33 & 60.04 & 0.00 & 24.79 & 0.55 & 0.00 & 0.00 & 7.44 & 6.29 & 0.90 & 0.00 & 0.00 \\
\hline Spectrum 39 & 59.79 & 0.00 & 24.94 & 0.60 & 0.00 & 0.00 & 7.48 & 6.34 & 0.86 & 0.00 & 0.00 \\
\hline Spectrum 40 & 59.21 & 0.00 & 25.32 & 0.53 & 0.00 & 0.00 & 7.97 & 6.17 & 0.79 & 0.00 & 0.00 \\
\hline Spectrum 41 & 58.25 & 0.00 & 25.78 & 0.58 & 0.00 & 0.00 & 8.45 & 5.98 & 0.75 & 0.00 & 0.20 \\
\hline Spectrum 70 & 59.76 & 0.00 & 24.97 & 0.58 & 0.00 & 0.00 & 7.59 & 6.26 & 0.82 & 0.00 & 0.00 \\
\hline Spectrum 71 & 58.79 & 0.00 & 25.55 & 0.60 & 0.00 & 0.00 & 8.24 & 6.05 & 0.77 & 0.00 & 0.00 \\
\hline Spectrum 72 & 60.40 & 0.00 & 24.49 & 0.54 & 0.00 & 0.00 & 7.14 & 6.48 & 0.96 & 0.00 & 0.00 \\
\hline Spectrum 73 & 58.85 & 0.00 & 25.52 & 0.59 & 0.00 & 0.00 & 8.20 & 6.12 & 0.74 & 0.00 & 0.00 \\
\hline Spectrum 79 & 59.28 & 0.00 & 25.21 & 0.57 & 0.00 & 0.00 & 7.88 & 6.21 & 0.84 & 0.00 & 0.00 \\
\hline Spectrum 80 & 58.40 & 0.00 & 25.82 & 0.53 & 0.00 & 0.00 & 8.50 & 5.94 & 0.79 & 0.00 & 0.00 \\
\hline Spectrum 81 & 58.67 & 0.15 & 25.53 & 0.56 & 0.00 & 0.00 & 8.16 & 6.13 & 0.79 & 0.00 & 0.00 \\
\hline Spectrum 82 & 59.11 & 0.00 & 25.31 & 0.60 & 0.00 & 0.00 & 8.05 & 6.13 & 0.80 & 0.00 & 0.00 \\
\hline Spectrum 83 & 59.74 & 0.00 & 25.02 & 0.47 & 0.00 & 0.00 & 7.65 & 6.22 & 0.88 & 0.00 & 0.00 \\
\hline Average feldspar & 59.59 & 0.01 & 25.14 & 0.49 & 0.00 & 0.00 & 7.73 & 6.20 & 0.84 & 0.00 & 0.01 \\
\hline$\sigma$ & 0.66 & 0.03 & 0.47 & 0.25 & 0.00 & 0.00 & 0.44 & 0.18 & 0.08 & 0.00 & 0.04 \\
\hline & $\begin{array}{l}\% \mathrm{Or} \\
\% \mathrm{Ab} \\
\% \mathrm{An}\end{array}$ & $\begin{array}{c}4.99 \\
56.23 \\
38.78 \\
\end{array}$ & & & & & & & & & \\
\hline
\end{tabular}




\section{Lower Littlefield Rhyolite: Sample BW-13-03}

Table 42: Results of scanning electron microscope quantitative analyses of lower Littlefield Rhyolite pyroxene phenocrysts, followed by the average end-member composition.

\begin{tabular}{|c|c|c|c|c|c|c|c|c|c|c|c|}
\hline $\begin{array}{l}\text { BW-13-03 pyroxene } \\
\text { SEM, normalized wt.\% }\end{array}$ & $\overline{\mathrm{SSiO2}}$ & Al203 & TiO2 & FeO & 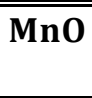 & " CaO & Mg0 & "K20 & Na20 & P205 & "Ba0 \\
\hline Spectrum 1 & 50.00 & 0.46 & 0.29 & 30.91 & 1.29 & 4.66 & 12.40 & 0.00 & 0.00 & 0.00 & 0.00 \\
\hline Spectrum 2 & 49.97 & 0.51 & 0.29 & 30.91 & 1.37 & 4.74 & 12.22 & 0.00 & 0.00 & 0.00 & 0.00 \\
\hline Spectrum 3 & 49.70 & 0.39 & 0.33 & 31.27 & 1.28 & 4.76 & 12.29 & 0.00 & 0.00 & 0.00 & 0.00 \\
\hline Spectrum 4 & 49.78 & 0.48 & 0.28 & 31.17 & 1.33 & 4.61 & 12.34 & 0.00 & 0.00 & 0.00 & 0.00 \\
\hline Spectrum 5 & 49.96 & 0.45 & 0.26 & 31.13 & 1.33 & 4.60 & 12.28 & 0.00 & 0.00 & 0.00 & 0.00 \\
\hline Spectrum 6 & 49.85 & 0.47 & 0.27 & 31.15 & 1.31 & 4.73 & 12.23 & 0.00 & 0.00 & 0.00 & 0.00 \\
\hline Spectrum 35 & 49.77 & 0.43 & 0.40 & 31.17 & 1.24 & 4.53 & 12.46 & 0.00 & 0.00 & 0.00 & 0.00 \\
\hline Spectrum 36 & 49.77 & 0.46 & 0.30 & 31.05 & 1.32 & 4.51 & 12.60 & 0.00 & 0.00 & 0.00 & 0.00 \\
\hline Spectrum 37 & 49.99 & 0.41 & 0.35 & 30.89 & 1.32 & 4.55 & 12.50 & 0.00 & 0.00 & 0.00 & 0.00 \\
\hline Average pyroxene & 49.87 & 0.45 & 0.31 & 31.07 & 1.31 & 4.63 & 12.37 & 0.00 & 0.00 & 0.00 & 0.00 \\
\hline$\sigma$ & 0.12 & 0.04 & 0.04 & 0.14 & 0.04 & 0.09 & 0.13 & 0.00 & 0.00 & 0.00 & 0.00 \\
\hline & \begin{tabular}{|c|}
$\%$ En \\
$\% \mathrm{Fs}$ \\
$\% \mathrm{Wo}$ \\
\end{tabular} & $\begin{array}{l}37.34 \\
52.61 \\
10.05\end{array}$ & & & & & & & & & \\
\hline
\end{tabular}

Table 43: Results of scanning electron microscope quantitative analyses of lower Littlefield Rhyolite titanomagnetite phenocrysts.

\begin{tabular}{cccccccccccc}
\hline \hline $\begin{array}{c}\text { BW-13-03 TiFe } \\
\text { SEM, normalized wt.\% }\end{array}$ & Si02 & Al203 & Ti02 & Fe0 & MnO & CaO & Mg0 & K20 & Na20 & P205 & Ba0 \\
\hline Spectrum 18 & 22.21 & 3.08 & 42.55 & 23.67 & 0.76 & 4.09 & 0.39 & 0.94 & 0.43 & 0.55 & 1.34 \\
Spectrum 19 & 21.90 & 3.15 & 42.37 & 23.06 & 0.78 & 4.59 & 0.50 & 0.91 & 0.38 & 1.08 & 1.27 \\
Spectrum 21 & 25.37 & 3.33 & 45.64 & 17.76 & 0.80 & 3.77 & 0.50 & 1.04 & 0.36 & 0.00 & 1.44 \\
Spectrum 24 & 16.35 & 2.73 & 38.26 & 36.84 & 0.80 & 2.46 & 0.55 & 0.64 & 0.43 & 0.00 & 0.97 \\
Spectrum 38 & 0.92 & 1.93 & 23.65 & 71.65 & 0.79 & 0.00 & 1.06 & 0.00 & 0.00 & 0.00 & 0.00 \\
\hline Average TiFe & 17.35 & 2.84 & 38.49 & 34.59 & 0.79 & 2.98 & 0.60 & 0.70 & 0.32 & 0.33 & 1.01 \\
$\sigma$ & 9.74 & 0.55 & 8.70 & 21.87 & 0.02 & 1.84 & 0.26 & 0.42 & 0.18 & 0.48 & 0.59 \\
\hline
\end{tabular}


Table 44: Results of scanning electron microscope quantitative analyses of lower Littlefield Rhyolite feldspar phenocrysts, followed by the average end-member composition.

\begin{tabular}{|c|c|c|c|c|c|c|c|c|c|c|c|}
\hline $\begin{array}{l}\text { BW-13-03 Feldspar } \\
\text { SEM, normalized wt.\% }\end{array}$ & $\overline{\mathrm{SiO} 2}$ & Al203 & Ti02 & $\overline{\mathrm{FeO}}$ & MnO & " CaO & "Mg0 & K20 & Na20 & P205 & Ba0 \\
\hline Spectrum 7 & 59.71 & 24.94 & 0.00 & 0.55 & 0.00 & 7.73 & 0.00 & 0.92 & 6.16 & 0.00 & 0.00 \\
\hline Spectrum 8 & 59.76 & 24.97 & 0.00 & 0.59 & 0.00 & 7.70 & 0.00 & 0.81 & 6.17 & 0.00 & 0.00 \\
\hline Spectrum 9 & 59.09 & 25.43 & 0.00 & 0.58 & 0.00 & 8.08 & 0.00 & 0.79 & 6.01 & 0.00 & 0.00 \\
\hline Spectrum 10 & 58.84 & 25.36 & 0.00 & 0.65 & 0.00 & 8.04 & 0.00 & 0.77 & 6.09 & 0.00 & 0.24 \\
\hline Spectrum 26 & 60.39 & 24.34 & 0.00 & 0.80 & 0.00 & 7.43 & 0.00 & 1.20 & 5.83 & 0.00 & 0.00 \\
\hline Spectrum 27 & 59.17 & 25.16 & 0.00 & 0.69 & 0.00 & 7.97 & 0.00 & 0.85 & 6.14 & 0.00 & 0.00 \\
\hline Spectrum 28 & 60.69 & 24.01 & 0.00 & 0.79 & 0.00 & 7.44 & 0.00 & 1.11 & 5.95 & 0.00 & 0.00 \\
\hline Average feldspar & 59.66 & 24.89 & 0.00 & 0.66 & 0.00 & 7.77 & 0.00 & 0.92 & 6.05 & 0.00 & 0.03 \\
\hline$\sigma$ & 0.69 & 0.53 & 0.00 & 0.10 & 0.00 & 0.27 & 0.00 & 0.17 & 0.13 & 0.00 & 0.09 \\
\hline & $\begin{array}{c}\% \mathrm{Or} \\
\% \mathrm{Ab} \\
\% \mathrm{An}\end{array}$ & $\begin{array}{c}5.55 \\
55.25 \\
39.21\end{array}$ & & & & & & & & & \\
\hline
\end{tabular}

Table 45: Results of scanning electron microscope quantitative analyses of lower Littlefield Rhyolite glassy groundmass.

\begin{tabular}{cccccccccccc}
\hline \hline $\begin{array}{c}\text { BW-13-03 glass } \\
\text { SEM, normalized wt.\% }\end{array}$ & Si02 & Al203 & Ti02 & FeO & MnO & CaO & Mg0 & K20 & Na20 & P205 & Ba0 \\
\hline Spectrum 11 & 75.72 & 11.64 & 0.40 & 2.64 & 0.00 & 0.79 & 0.12 & 6.44 & 1.98 & 0.00 & 0.26 \\
Spectrum 12 & 75.41 & 11.60 & 0.44 & 2.65 & 0.00 & 0.77 & 0.17 & 6.43 & 2.30 & 0.00 & 0.25 \\
Spectrum 13 & 75.70 & 11.63 & 0.50 & 2.67 & 0.00 & 0.82 & 0.00 & 6.12 & 2.55 & 0.00 & 0.00 \\
Spectrum 14 & 75.59 & 11.68 & 0.51 & 2.80 & 0.00 & 0.86 & 0.15 & 5.78 & 2.63 & 0.00 & 0.00 \\
Spectrum 29 & 75.26 & 11.50 & 0.61 & 2.99 & 0.00 & 0.97 & 0.17 & 6.37 & 2.13 & 0.00 & 0.00 \\
Spectrum 30 & 75.28 & 11.55 & 0.54 & 2.83 & 0.00 & 0.86 & 0.12 & 6.56 & 2.02 & 0.00 & 0.25 \\
Spectrum 31 & 75.09 & 11.59 & 0.54 & 2.91 & 0.13 & 0.99 & 0.12 & 6.57 & 2.07 & 0.00 & 0.00 \\
\hline Average glass & 75.44 & 11.60 & 0.51 & 2.78 & 0.02 & 0.87 & 0.12 & 6.32 & 2.24 & 0.00 & 0.11 \\
$\sigma$ & 0.24 & 0.06 & 0.07 & 0.14 & 0.05 & 0.09 & 0.06 & 0.28 & 0.26 & 0.00 & 0.13 \\
\hline
\end{tabular}

Table 46: Results of scanning electron microscope quantitative analyses of lower Littlefield Rhyolite apatite microlites.

\begin{tabular}{cccccccccccc}
\hline \hline $\begin{array}{c}\text { BW-13-03 apatite } \\
\text { SEM, normalized wt.\% }\end{array}$ & Si02 & Al203 & TiO2 & FeO & MnO & CaO & Mg0 & K20 & Na20 & P205 & Ba0 \\
\hline Spectrum 22 & 0.41 & 0.14 & 0.20 & 1.17 & 0.15 & 56.73 & 0.11 & 0.00 & 0.00 & 41.09 & 0.00 \\
Spectrum 23 & 1.13 & 0.19 & 3.41 & 4.80 & 0.00 & 52.06 & 0.16 & 0.00 & 0.13 & 38.14 & 0.00 \\
Spectrum 25 & 0.57 & 0.00 & 0.00 & 0.64 & 0.00 & 57.05 & 0.13 & 0.08 & 0.15 & 41.39 & 0.00 \\
Spectrum 32 & 0.35 & 0.14 & 0.00 & 1.15 & 0.00 & 56.63 & 0.13 & 0.00 & 0.00 & 41.60 & 0.00 \\
Spectrum 33 & 0.42 & 0.00 & 0.00 & 1.06 & 0.00 & 56.63 & 0.00 & 0.09 & 0.15 & 41.66 & 0.00 \\
Spectrum 34 & 1.55 & 0.26 & 0.00 & 1.46 & 0.00 & 54.12 & 0.22 & 0.17 & 0.00 & 42.24 & 0.00 \\
\hline Average apatite & 0.74 & 0.12 & 0.60 & 1.71 & 0.02 & 55.54 & 0.12 & 0.06 & 0.07 & 41.02 & 0.00 \\
$\sigma$ & 0.49 & 0.10 & 1.38 & 1.53 & 0.06 & 2.01 & 0.07 & 0.07 & 0.08 & 1.46 & 0.00 \\
\hline
\end{tabular}




\section{APPENDIX E: ${ }^{40} \mathrm{Ar} /{ }^{39} \mathrm{Ar}$ DATING OF RHYOLITE LAVAS}

Single crystal ${ }^{40} \mathrm{Ar} /{ }^{39} \mathrm{Ar}$ age dates for 7 rhyolite samples were performed the New Mexico Geochronology Research Laboratory under the supervision of William McIntosh. The resulting age determinations are relative to Fish Canyon Tuff (FC-1) sanidine monitors. A summary of the results are provided below. Detailed results are shown in the pages that follow.

Table 47: Single crystal ${ }^{40} \mathrm{Ar} /{ }^{39} \mathrm{Ar}$ dates for 2 samples of upper Littlefield Rhyolite, 3 samples of lower Littlefield Rhyolite, 1 sample of the rhyolite of Bully Creek Canyon, and 1 sample of the rhyolite of Cottonwood Mountain. *Denotes repeat analysis. The initial analysis of sample BW-13-02 yielded significant error $( \pm 0.3)$ compared to samples BW-14-29a and BW-14-19, which yielded similar ages with acceptable errors. Sample BW-13-02* was analyzed a second time and again yielded questionable results.

\begin{tabular}{|c|c|c|c|c|c|c|}
\hline Unit & Sample ID & Method & Age (Ma) & Error $( \pm 2 \sigma)$ & $\mathbf{n}$ & MSWD \\
\hline upper Littlefield Rhyolite & BW-14-40 & ${ }^{40} \mathrm{Ar} /{ }^{39} \mathrm{Ar}$ & 16.01 & \pm 0.06 & 12 & 2.8 \\
\hline upper Littlefield Rhyolite & BW-14-67 & ${ }^{40} \mathrm{Ar} /{ }^{39} \mathrm{Ar}$ & 16.05 & \pm 0.04 & 11 & 2.1 \\
\hline lower Littlefield Rhyolite & BW-14-29a & ${ }^{40} \mathrm{Ar} /{ }^{39} \mathrm{Ar}$ & 16.12 & \pm 0.04 & 11 & 0.7 \\
\hline lower Littlefield Rhyolite & BW-14-19 & ${ }^{40} \mathrm{Ar} /{ }^{39} \mathrm{Ar}$ & 16.16 & \pm 0.10 & 12 & 3.9 \\
\hline lower Littlefield Rhyolite & BW-13-02 & ${ }^{40} \mathrm{Ar} /{ }^{39} \mathrm{Ar}$ & 16.3 & \pm 0.30 & 6 & 0.04 \\
\hline lower Littlefield Rhyolite & BW-13-02* & ${ }^{40} \mathrm{Ar} /{ }^{39} \mathrm{Ar}$ & 15.9 & \pm 0.37 & 7 & 2.48 \\
\hline rhyolite of Bully Creek Canyon & $\mathrm{EJ}-12-17$ & ${ }^{40} \mathrm{Ar} /{ }^{39} \mathrm{Ar}$ & 16.12 & \pm 0.07 & 12 & 4.1 \\
\hline rhyolite of Cottonwood Mtn. & MS-12-31 & ${ }^{40} \mathrm{Ar} /{ }^{39} \mathrm{Ar}$ & 16.20 & \pm 0.08 & 10 & 3.7 \\
\hline
\end{tabular}



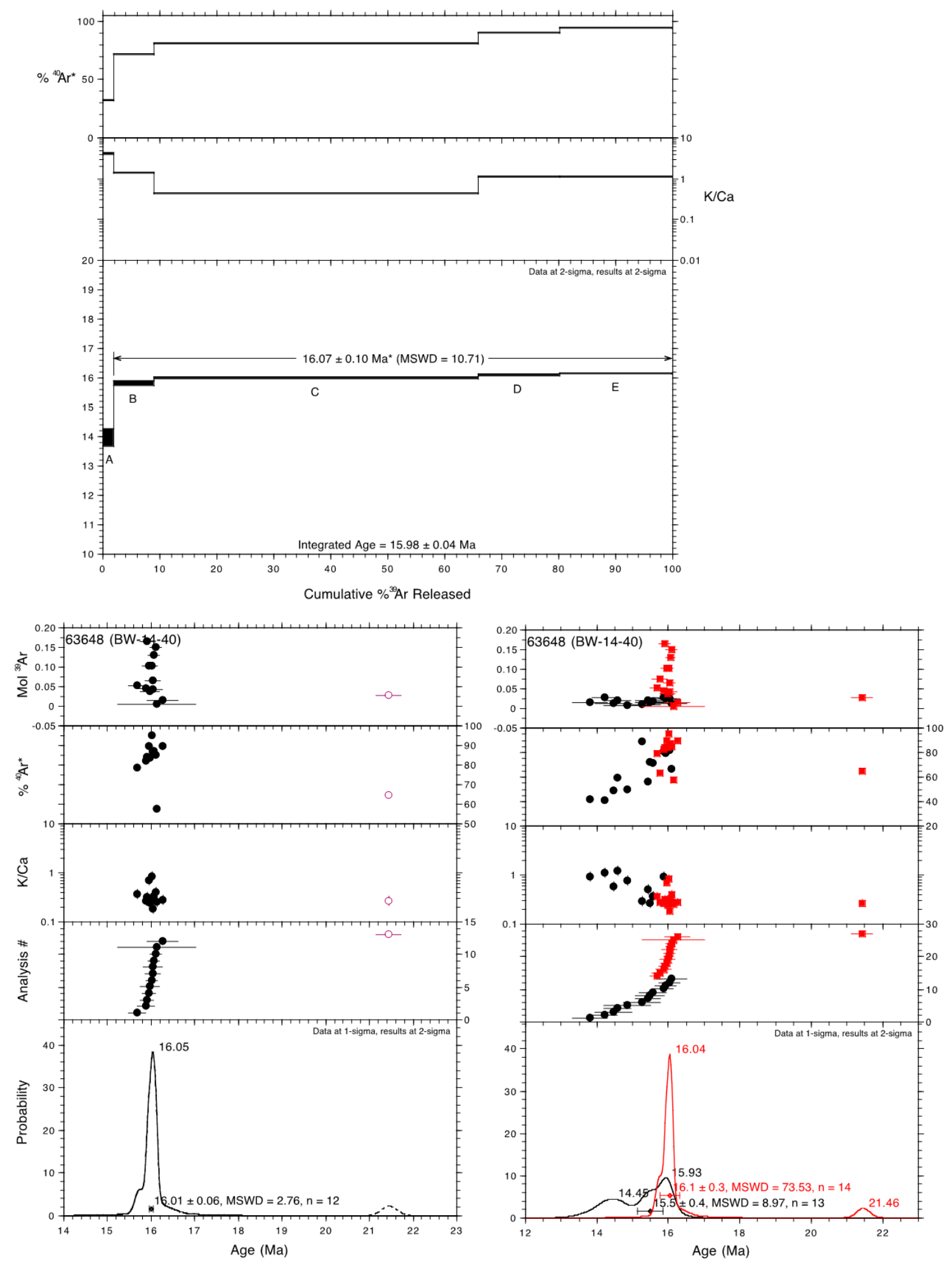

Figure 71: Single Crystal ${ }^{40} \mathrm{Ar} /{ }^{39} \mathrm{Ar}$ dating of upper Littlefield Rhyolite, sample BW-14-40. 

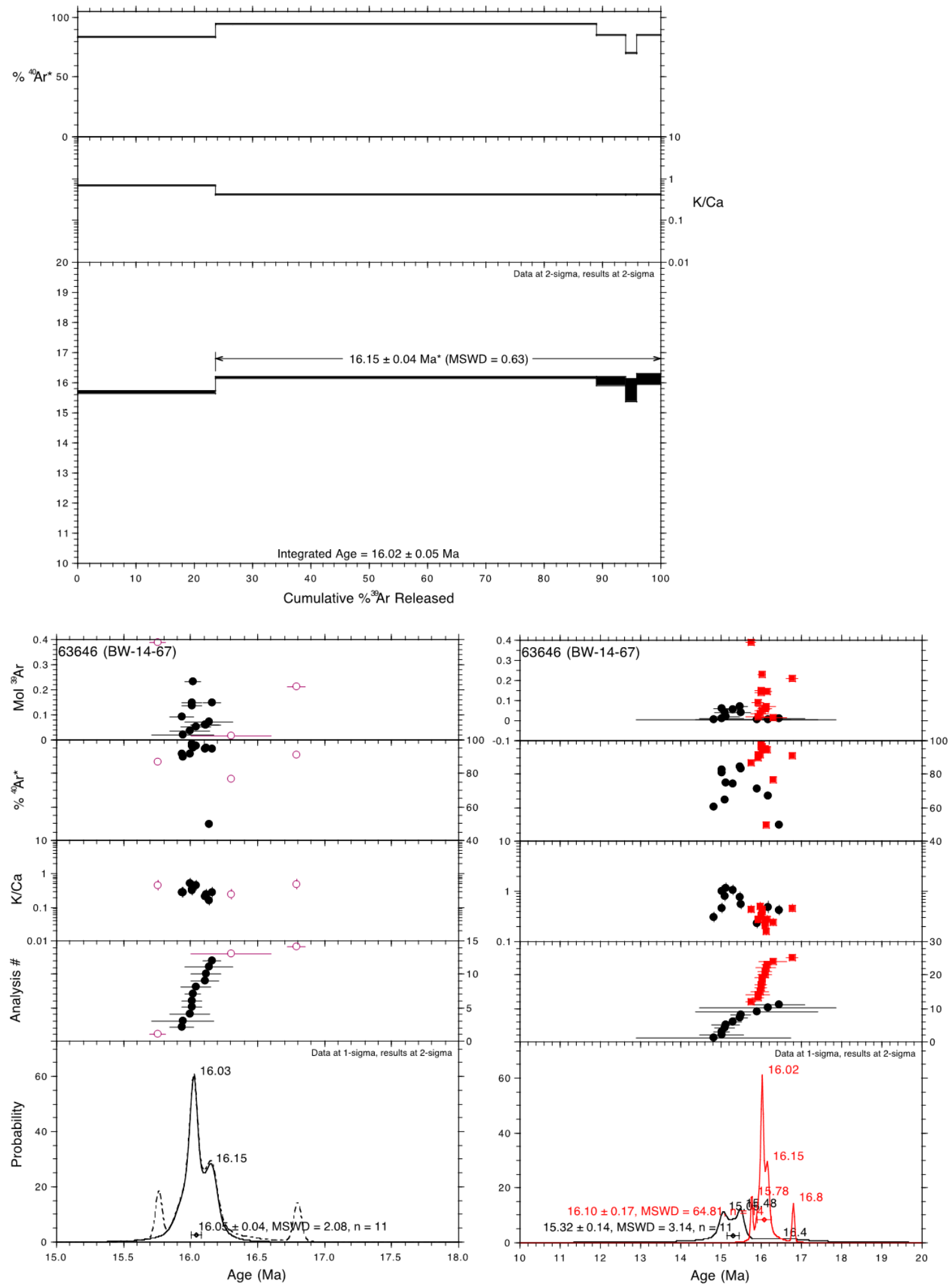

Figure 72: Single Crystal ${ }^{40} \mathrm{Ar} /{ }^{39} \mathrm{Ar}$ dating of upper Littlefield Rhyolite, sample BW-14-67. 

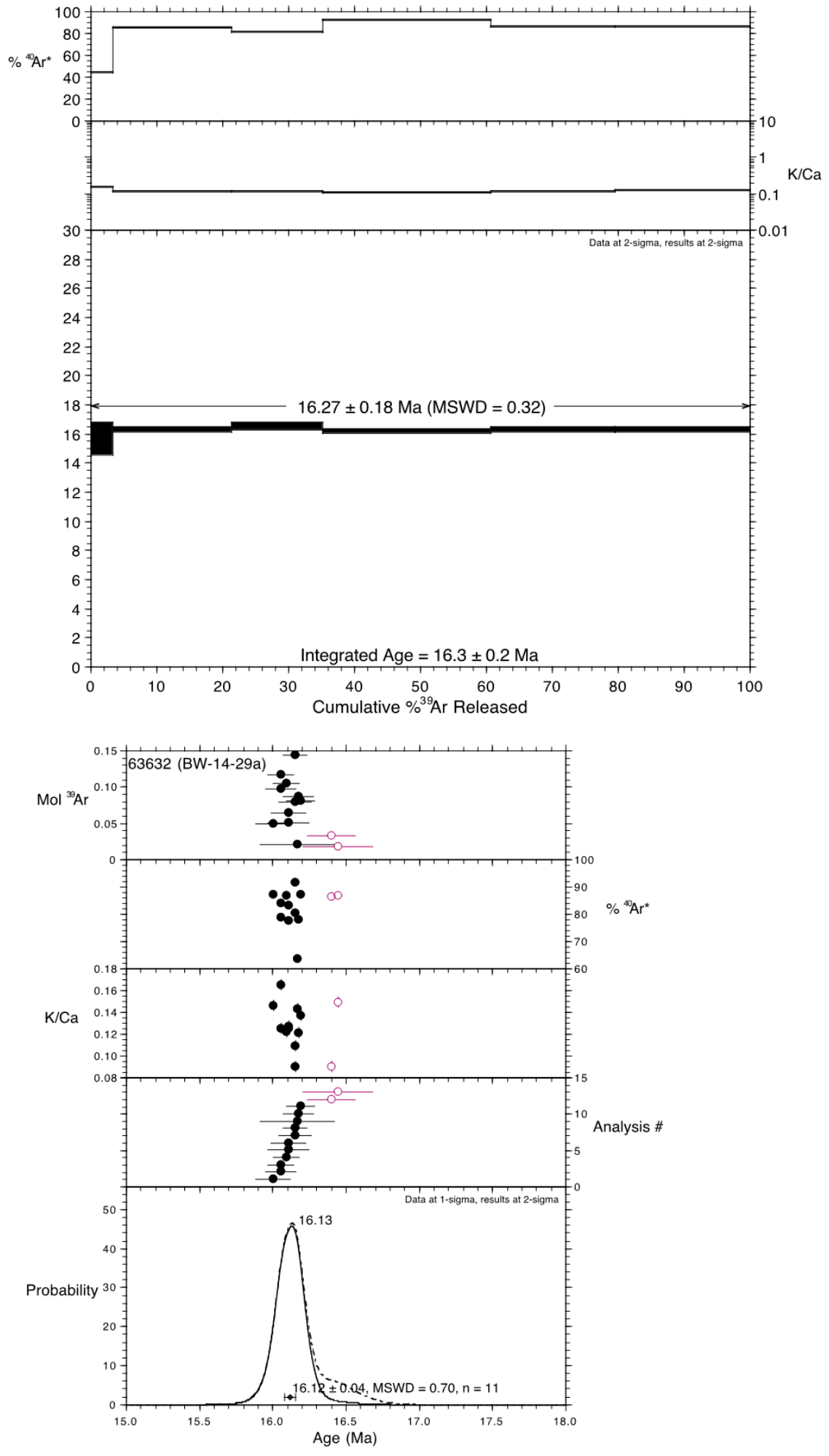

Figure 73: Single Crystal ${ }^{40} \mathrm{Ar} /{ }^{39} \mathrm{Ar}$ dating of lower Littlefield Rhyolite, sample BW-14-29a (Figure 1 of 2). 

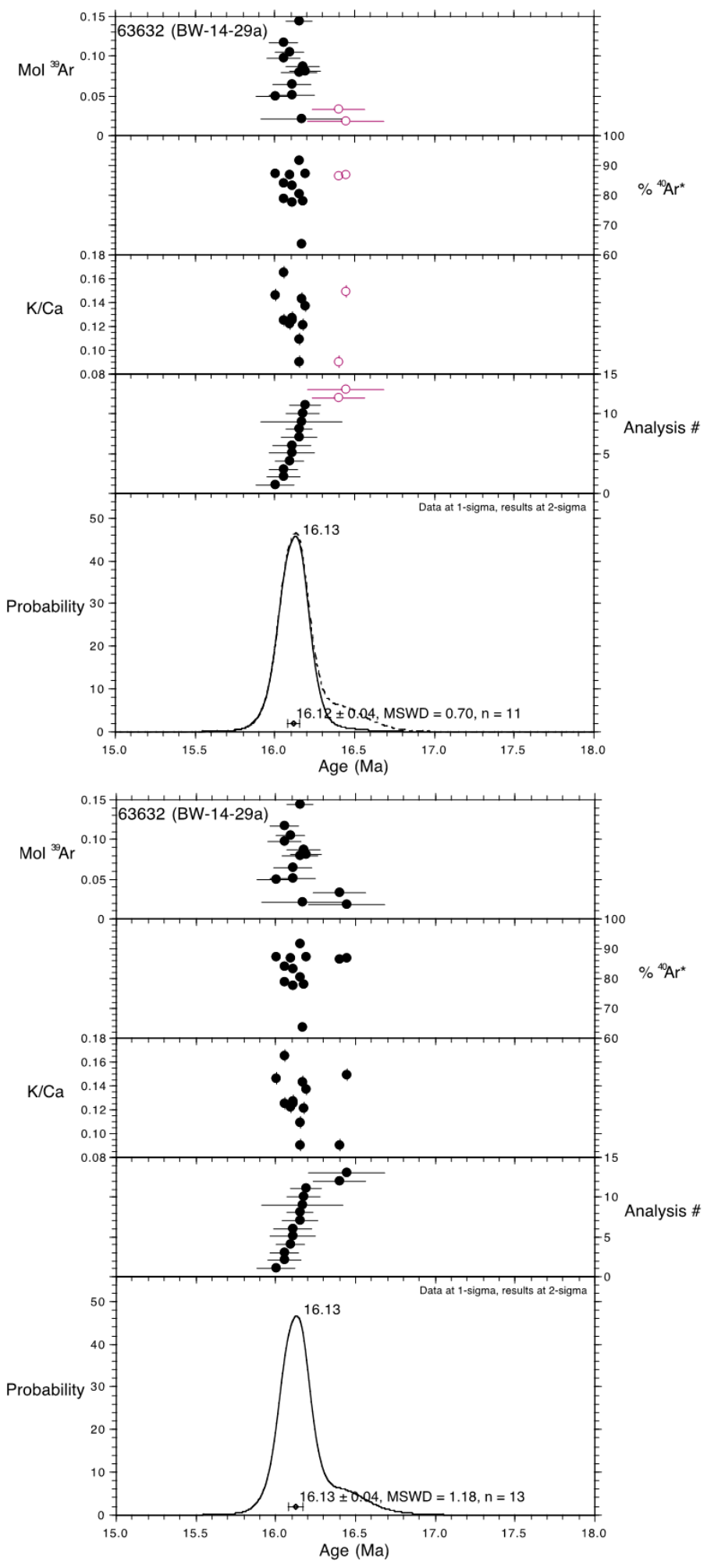

Figure 74: Single Crystal ${ }^{40} \mathrm{Ar} /{ }^{39} \mathrm{Ar}$ dating of lower Littlefield Rhyolite, sample BW-14-29a (Figure 2 of 2). 

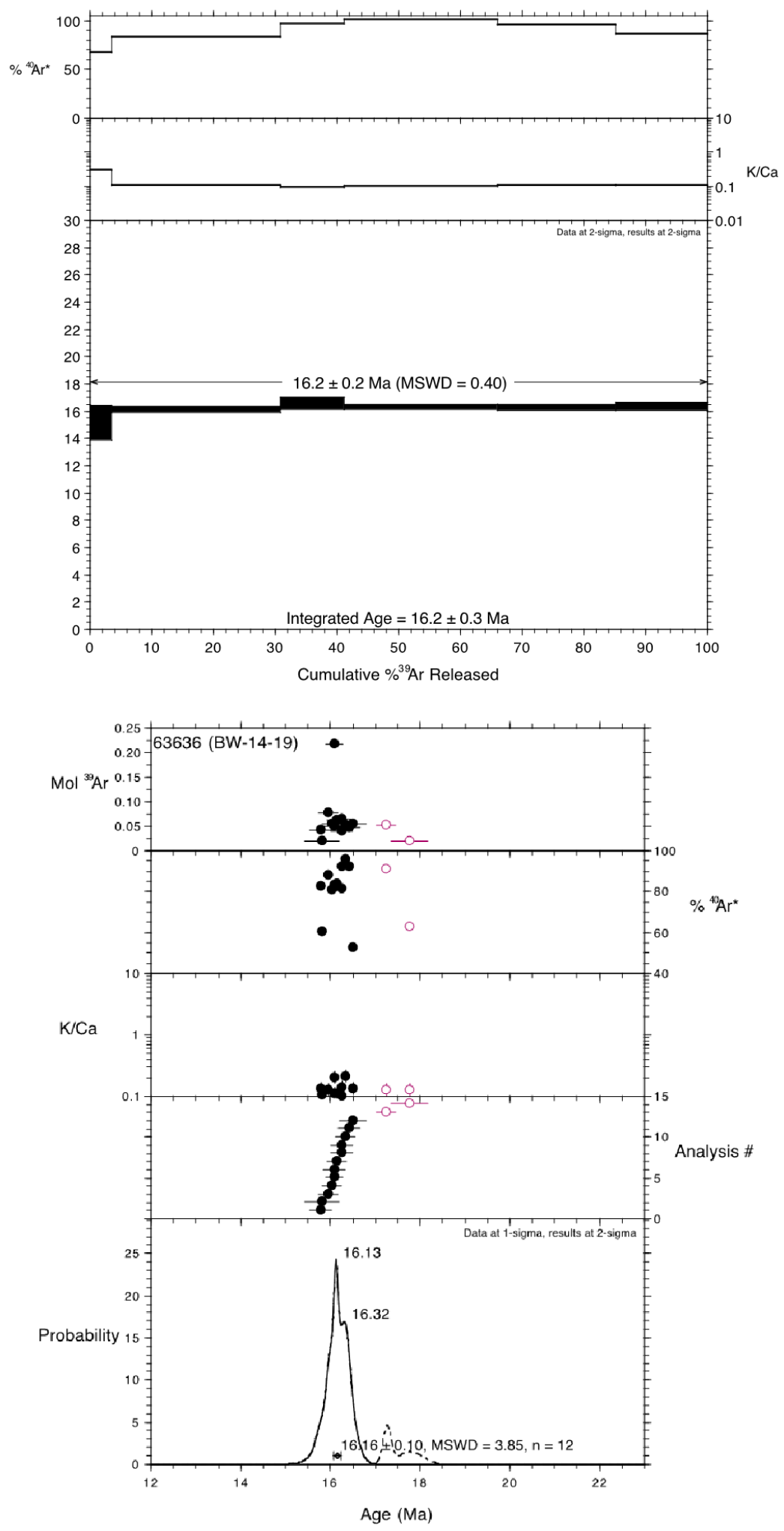

Figure 75: Single Crystal ${ }^{40} \mathrm{Ar} /{ }^{39} \mathrm{Ar}$ dating of lower Littlefield Rhyolite, sample BW-14-19. 


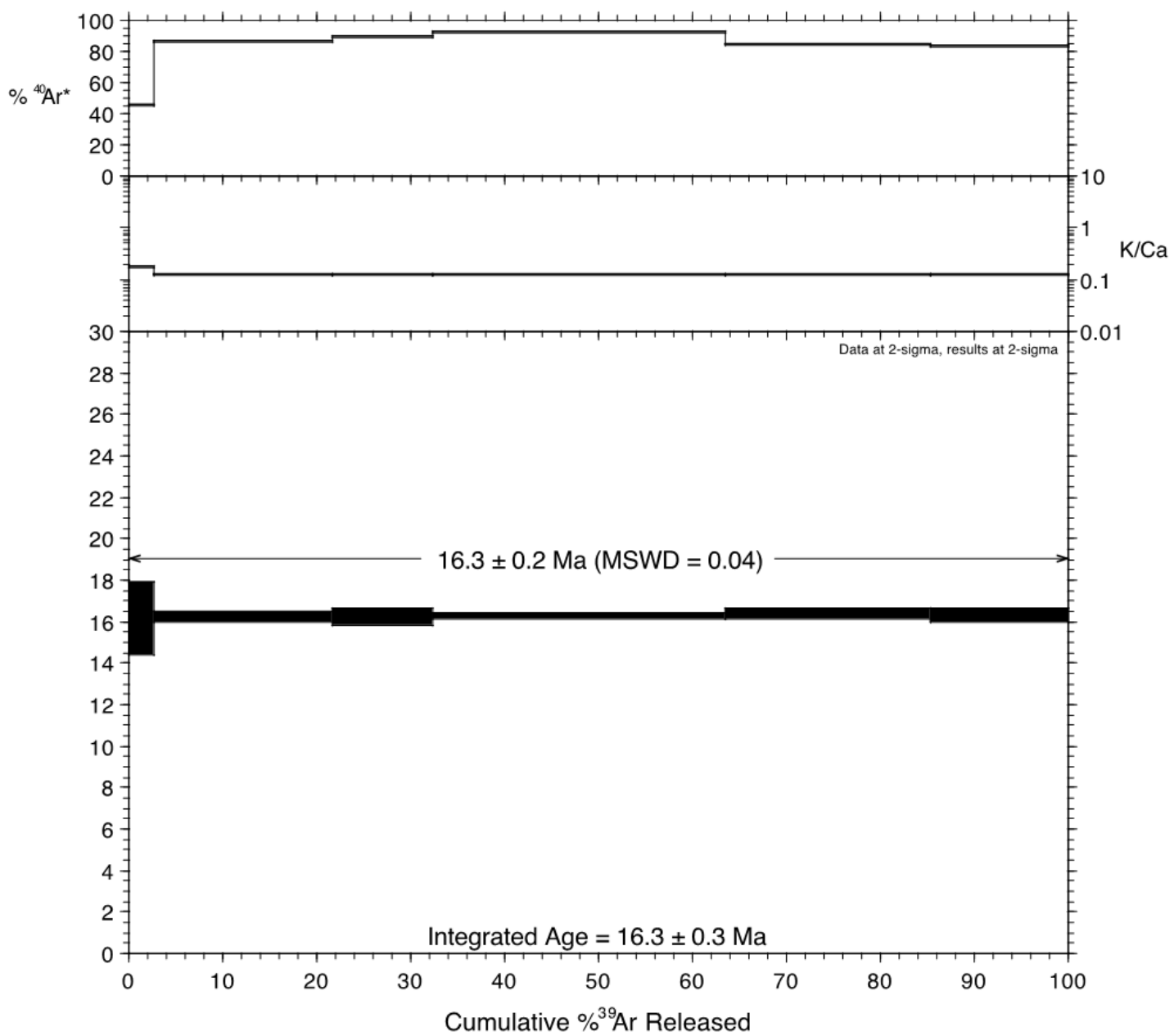

Figure 76: Single Crystal ${ }^{40} \mathrm{Ar} /{ }^{39} \mathrm{Ar}$ dating of lower Littlefield Rhyolite, sample BW-13-02. 

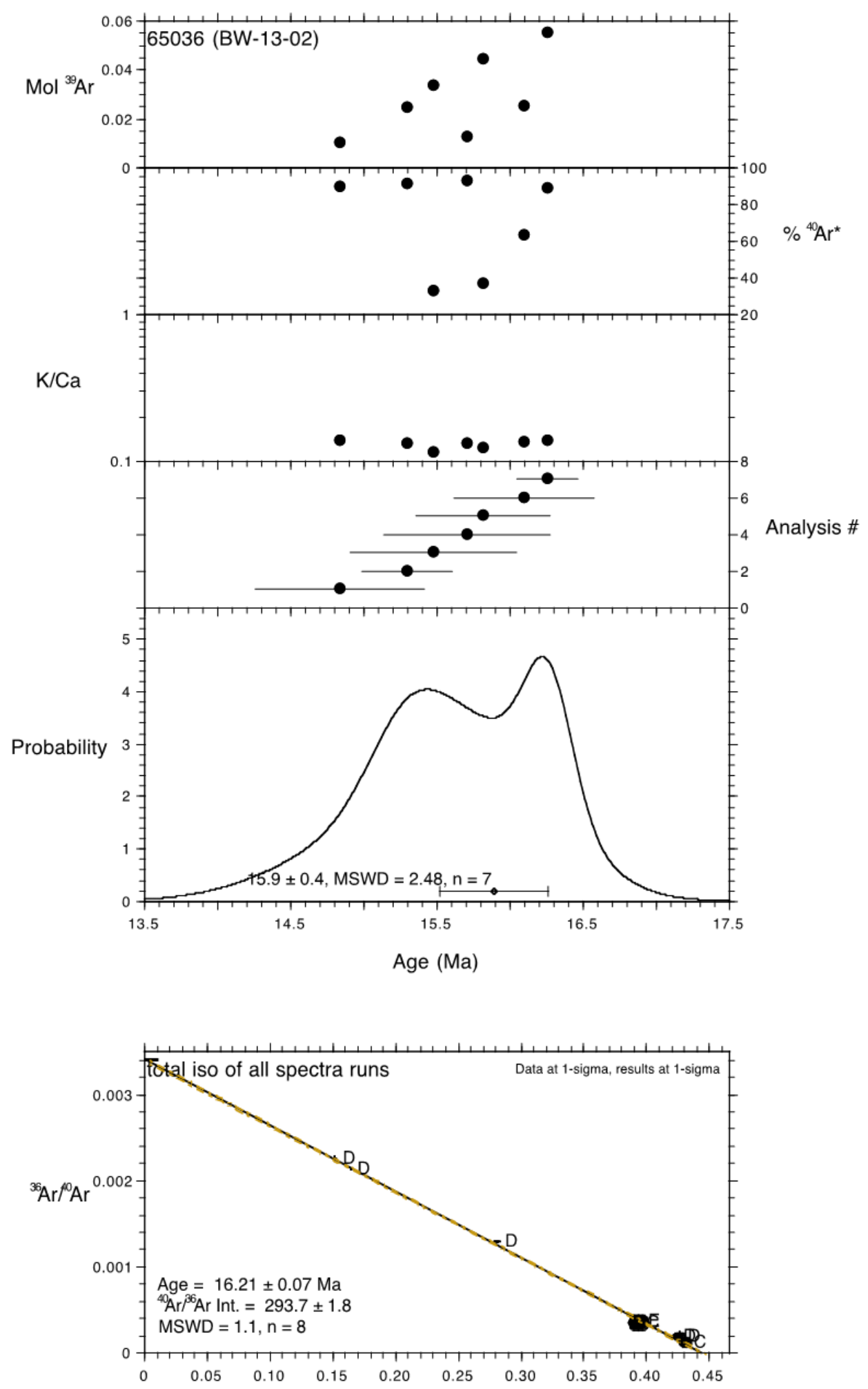

Figure 77: Single Crystal ${ }^{40} \mathrm{Ar} /{ }^{39} \mathrm{Ar}$ dating of lower Littlefield Rhyolite, sample BW-13-02* (repeat analysis). 

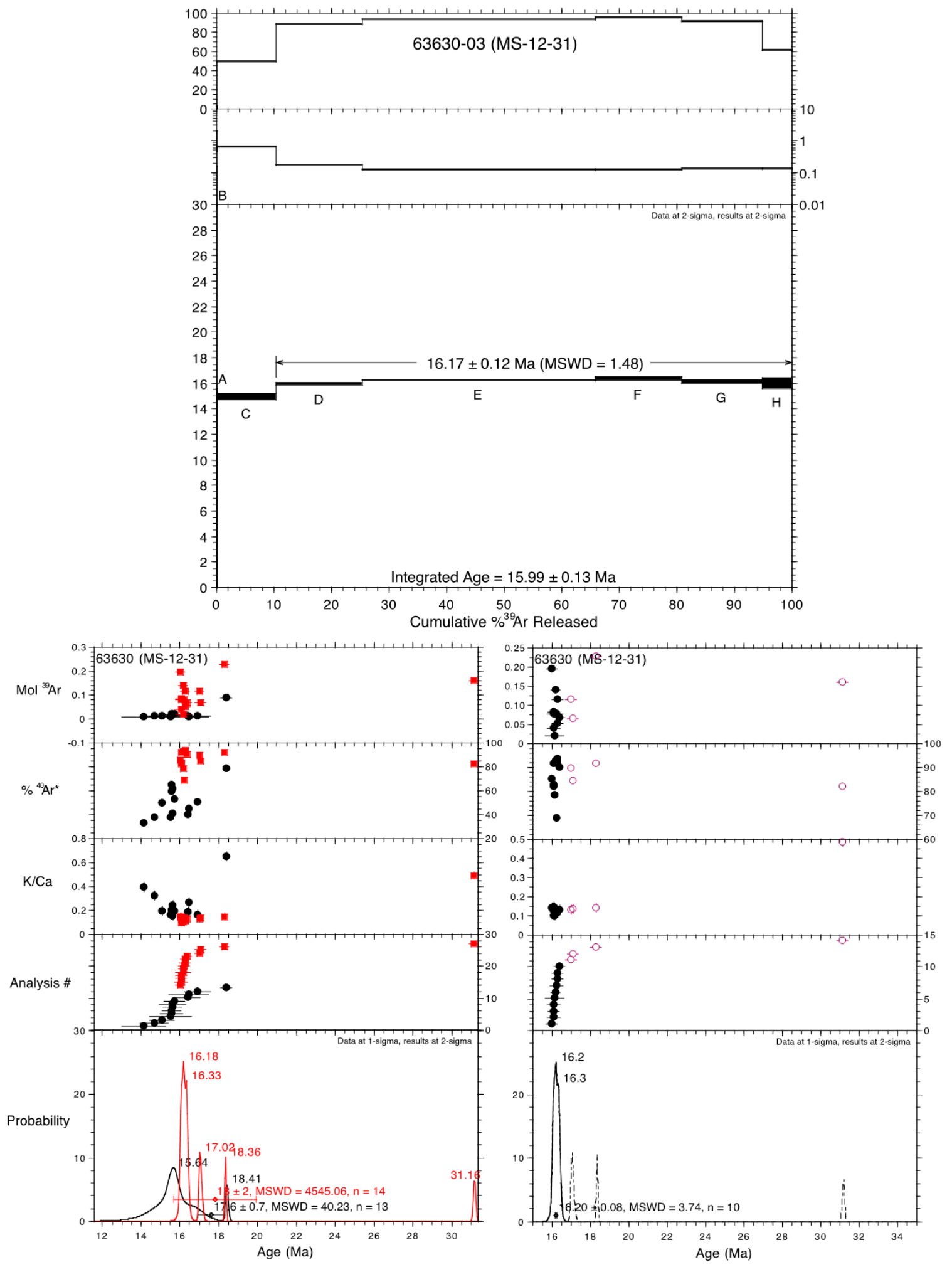

Figure 78: Single Crystal ${ }^{40} \mathrm{Ar} /{ }^{39} \mathrm{Ar}$ dating of the rhyolite of Cottonwood Mountain, sample MS12-31. 

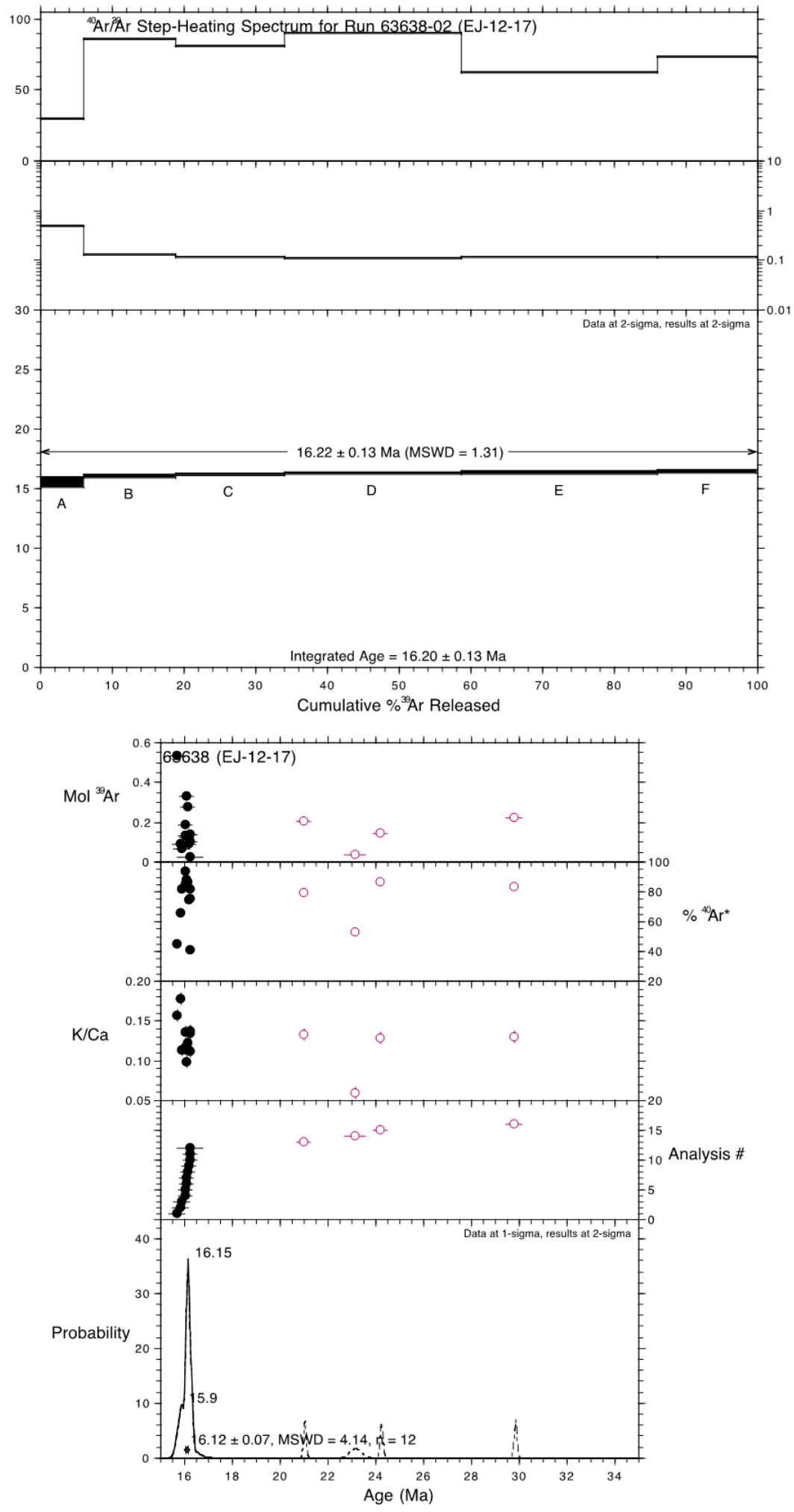

Figure 79: Single Crystal ${ }^{40} \mathrm{Ar} /{ }^{39} \mathrm{Ar}$ dating of the rhyolite of Bully Creek Canyon, sample EJ-1217. 
APPENDIX F: GEOLOGICAL MAP OF THE PRIMARY TRANSECT SITE AT NAMORF

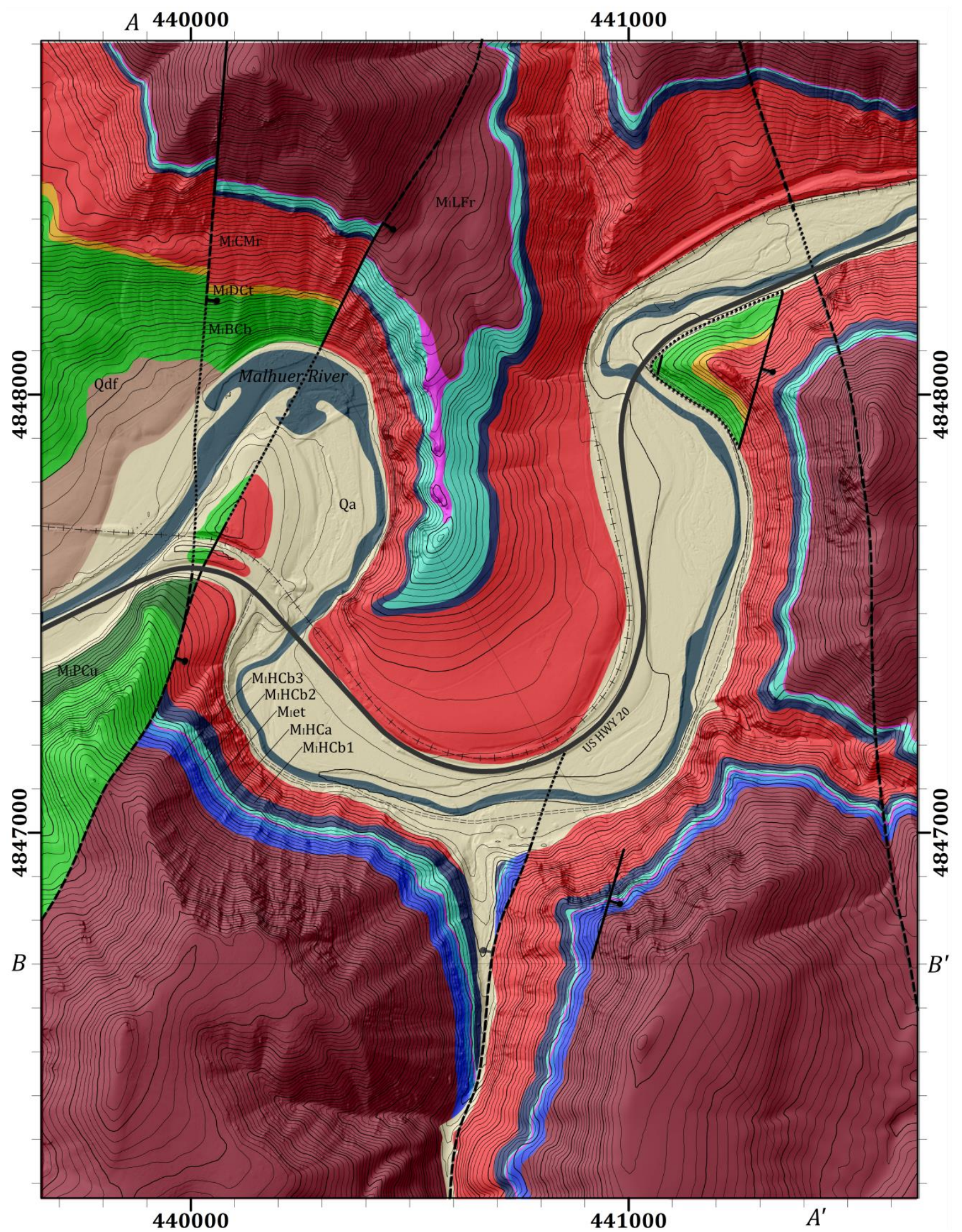

Figure 80: Namorf geological map. Datum and projection is NAD 83, UTM 11N. Vertical datum is NAVD88 (Geoid 12A). $5 \mathrm{~m}$ contour interval with index contours every $25 \mathrm{~m}$. 

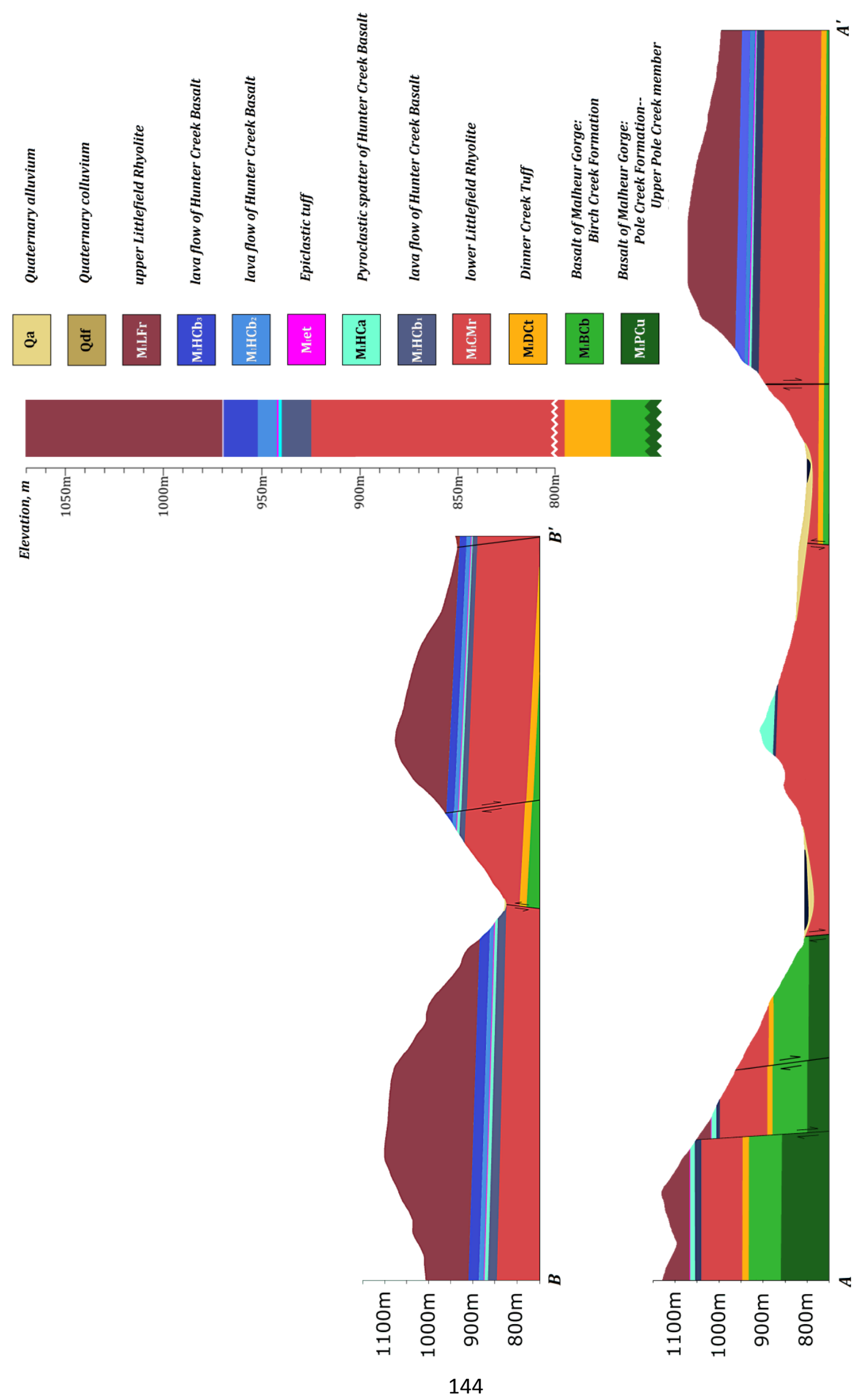